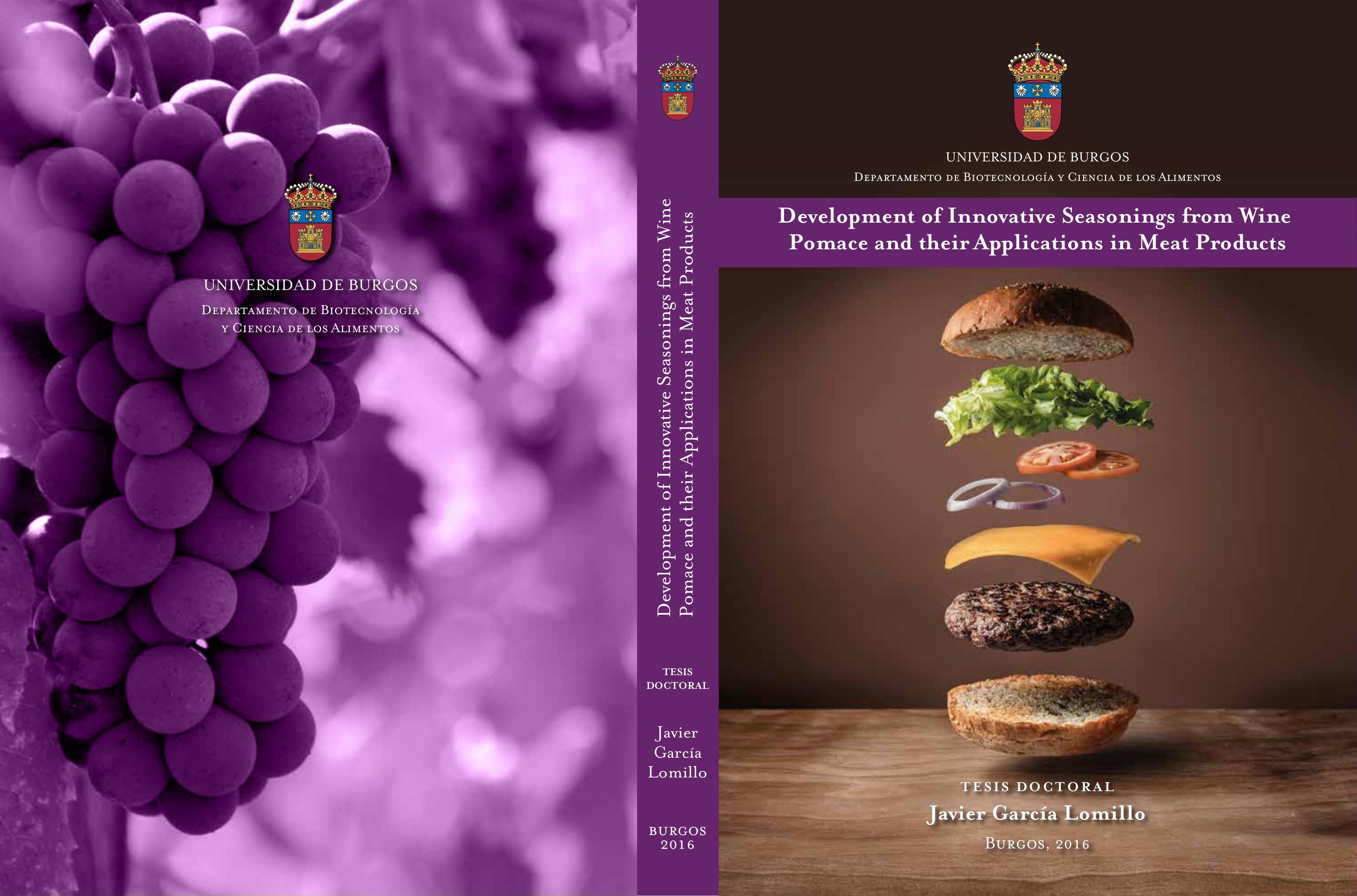





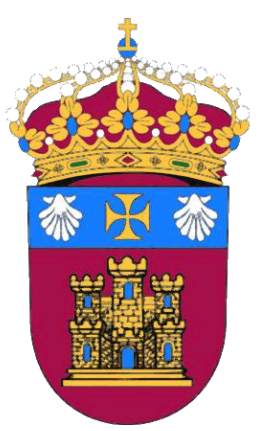

\section{UNIVERSIDAD DE BURGOS}

DEPARTAMENTO DE BIOTECNOLOGÍA Y CIENCIA DE LOS ALIMENTOS

TESIS DOCTORAL

DEVELOPMENT OF INNOVATIVE SEASONINGS FROM WINE POMACE AND THEIR APPLICATIONS IN MEAT PRODUCTS

JAVIER GarCía LOMILlo

BURGOS, 2016 



\title{
DEVELOPMENT OF INNOVATIVE SEASONINGS FROM WINE POMACE AND THEIR APPLICATIONS IN MEAT PRODUCTS
}

\author{
Memoria presentada para optar al grado de \\ Doctor en Avances en Ciencia y Biotecnología \\ Alimentarias por la Universidad de Burgos
}

Fdo.: Javier García Lomillo

\section{DIRECTORA}

Fdo: Dra. Ma Luisa González San José

Prof. Titular de la Universidad de Burgos 

UNIVERSIDAD DE BURGOS

DEPARTAMENTO DE BIOTECNOLOGÍA

Y CIENCIA DE LOS ALIMENTOS

DÑA. Ma LUISA GONZÁlEZ SAN JOSÉ, PROFESORA TITULAR DE UNIVERSIDAD EN EL ÁREA DE TECNOLOGÍA DE LOS ALIMENTOS DEL DEPARTAMENTO DE BIOTECNOLOGÍA Y CIENCIA DE LOS ALIMENTOS DE LA UNIVERSIDAD DE BURGOS, COMO DIRECTORA DE LA TESIS DOCTORAL "Development of innovative seasonings from wine pomace and their applications in meat products" desarrollada por D. Javier García Lomillo,

INFORMA favorablemente la presentación de dicha tesis, ya que reúne las condiciones necesarias para su defensa en cuanto a la realización de la fase experimental y la elaboración de la memoria.

Y para que así conste y a los efectos oportunos, firma el presente informe, en Burgos, a dieciséis de mayo de dos mil dieciséis,

Fdo. Ma Luisa González San José 



\author{
UNIVERSIDAD DE BURGOS \\ DEPARTAMENTO DE BIOTECNOLOGÍA \\ Y CIENCIA DE LOS ALIMENTOS
}

Dña. PILAR MUÑIZ RODRÍGUEZ, PROFESORA TITULAR DE LA UNIVERSIDAD DE BURGOS, EN SU CALIDAD DE DIRECTORA DEL DEPARTAMENTO DE BIOTECNOLOGÍA Y CIENCIA DE LOS ALIMENTOS,

CERTIFICA QUE: la memoria titulada "Development of innovative seasonings from wine pomace and their applications in meat products" presentada por D. Javier García Lomillo, Licenciado en Ciencia y Tecnología de los Alimentos, ha sido realizada en la en el Área de Tecnología de los Alimentos bajo la dirección de la Doctora Ma Luisa González San José, Profesora titular del Área, y en representación del Consejo de Departamento, autoriza su presentación para ser defendida como Tesis Doctoral.

Y para que conste, y a efectos oportunos, firma el presente certificado, en Burgos a dieciséis de mayo de dos mil dieciséis,

Fdo. Pilar Muñiz Rodríguez 

Esta tesis se ha realizado gracias a la ayuda para la contratación de Personal de Investigación de Reciente Titulación Universitaria (PIRTU) cofinanciada por la Consejería de Educación de la Junta de Castilla y León y el Fondo Social Europeo y al Programa de Formación de Profesorado Universitario (FPU) del Ministerio de Educación, Cultura y Deporte.

Este trabajo de Tesis doctoral ha sido realizado en el marco de los proyectos con referencia BU268A11-2 y BU282U13 de la Consejería de Educación de la Junta de Castilla y León. 

"Experience is what you get when you didn't get what you wanted" Randy Pausch 



\section{Agradecimientos}

En primer lugar agradecer a mi directora Marisa por guiarme en este camino. Mi más sincero agradecimiento por tu tiempo, pasión e interés dedicados a mi formación y desarrollo personal que me han permitido llegar hasta aquí y que me llevo para siempre.

I also want to thank Professor Leif Skibsted and Sisse Jongberg for giving me the opportunity to work in your laboratory. I learnt a lot about protein oxidation, but much more about life. I really appreciate your patience, guidance and your generous interest in my education.

Muito obrigado á Professora Isabel Ferreira e Olga Viegas pela sua dedicação durante a minha estância na Universidade do Porto. Foi uma experiência inesquecível e é um prazer encontrar investigadores de vosso nível sempre dispostos a ajudar. Muito obrigado também ao Edgar e ao Armindo pela vossa ajuda no laboratório.

A mi familia por el apoyo recibido durante todos estos años, siempre apoyándome en todos y cada uno de mis proyectos.

A mis amigos que me han acompañado no solo en la tesis sino durante mucho tiempo, me habéis tenido que aguantar, me habéis escuchado y apoyado. No tengo duda: sois unos amigos Premium.

A todos los compañeros de Facultad que me habéis apoyado en los pasillos, en la cafetería o delante de unas pizzas. Muchas gracias a Raquel por tu positivismo y tu forma de ver la vida que siempre me sostuvieron en los momentos de duda. ¡LO CONSEGUIMOS! Muchas gracias también a David por escucharme y sacarme una carcajada en los momentos más complicados. Y recuerda: la copa es nuestro torneo. 
Por tu apoyo, ayuda, comprensión, por aguantar los momentos complicados ¡MIL GRACIAS ERICA!

Esto no termina aquí. Mañana mismo comienzo nuevos objetivos que estoy seguro conseguiremos juntos. „OS ESPERO A TODOS! 


\section{INDEX}





\section{INDEX}

CONTEXTUALIZACIÓN Y OBJETIVOS/CONTEXTUALIZATION AND

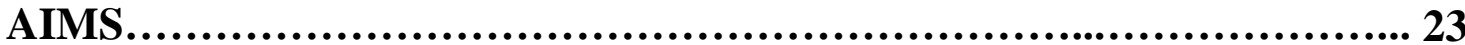

LIST OF ABBREVIATIONS............................................ 33

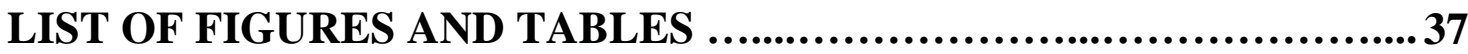

CHAPTER 1. APPLICATIONS OF WINE POMACE IN THE FOOD INDUSTRY: APPROACHES AND FUNCTIONS.......................45

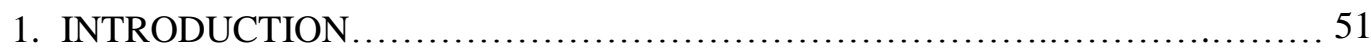

2. COMPOSITION OF WINE POMACE .......................................... 52

2.1. Water content and microbial stability ............................. 53

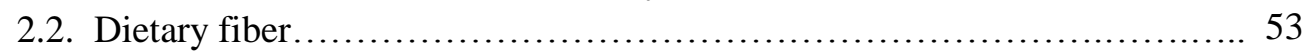

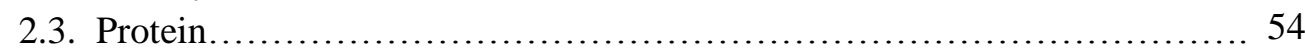

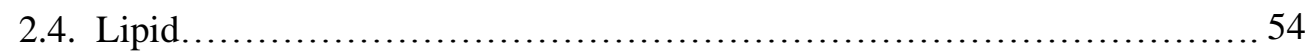

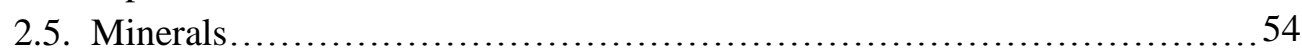

2.6. Phenolic compounds............................................. 55

3. APPROACHES IN THE APPLICATIONS OF WINE POMACE IN THE FOOD

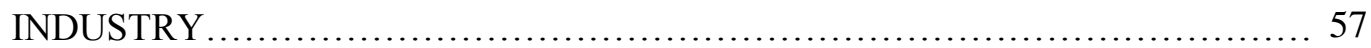

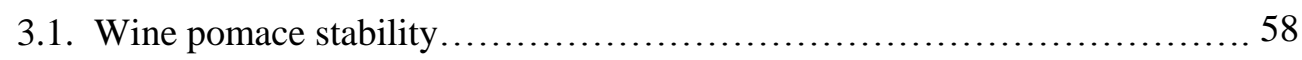

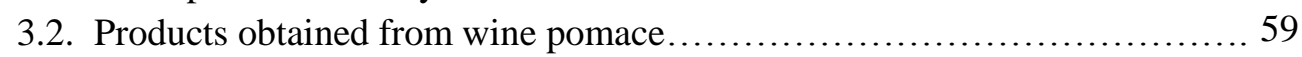

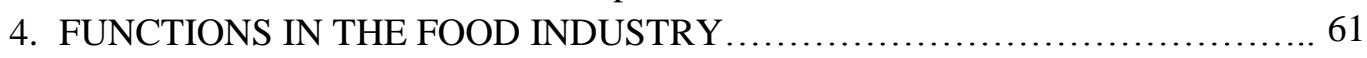

4.1. Improvement of nutritional properties and possible health effects........... 61

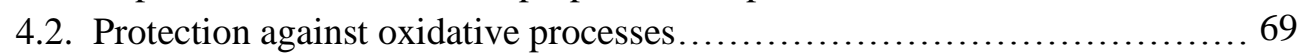

4.3. Interaction with microorganims in food .............................. 75

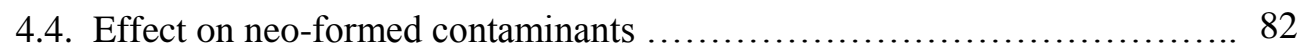

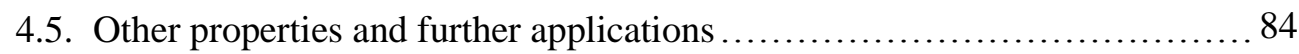

CHAPTER 2: ANTIOXIDANT AND ANTIMICROBIAL PROPERTIES OF WINE BY-PRODUCTS AND THEIR POTENTIAL USES IN THE FOOD INDUSTRY ....................................................109

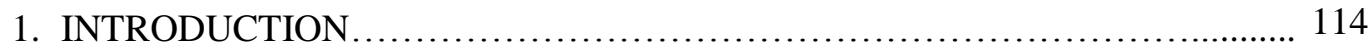

2. MATERIALS AND METHODS ............................................... 116

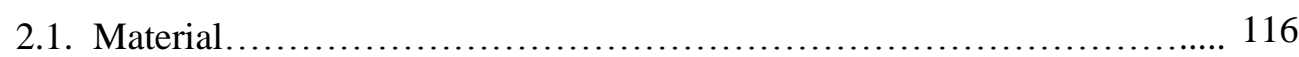

2.2. Analytical methodologies........................................ 116

2.3. Statistical analysis.............................................. 119

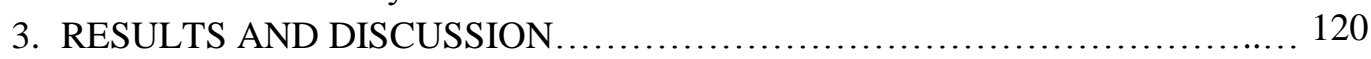

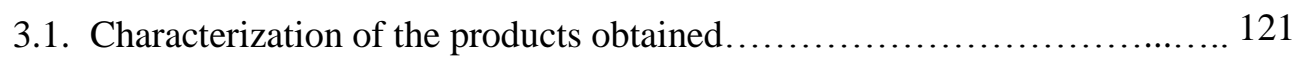

3.2. Properties of interest for food industry applications..................... 127

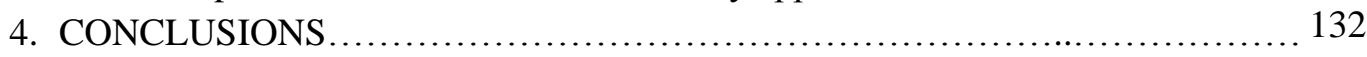


CHAPTER 3: ALTERNATIVE NATURAL SEASONING TO IMPROVE THE MICROBIAL STABILITY OF LOW-SALT BEEF PATTIES.......139

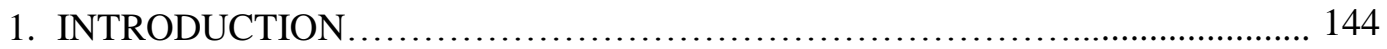

2. MATERIALS AND METHODS ................................................ 145

2.1. Materials and chemicals ................................................. 145

2.2. Patty preparation...................................................... 146

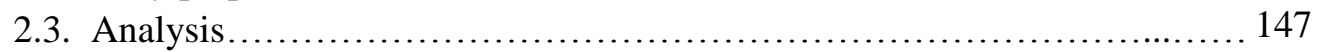

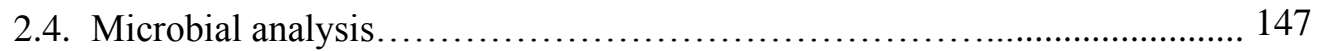

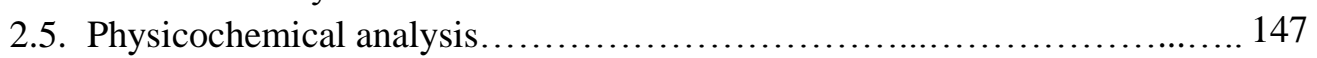

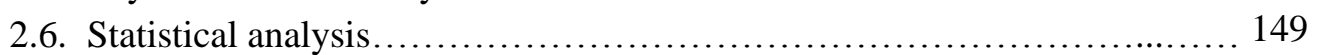

3. RESULTS AND DISCUSSION .......................................... 149

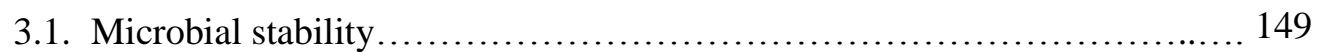

3.2. Effect of RWPS on beef patty composition........................................ 159

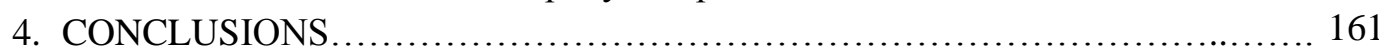

\section{CHAPTER 4: A NEW SEASONING WITH POTENTIAL EFFECT} AGAINST FOODBORNE PATHOGENS.................................165

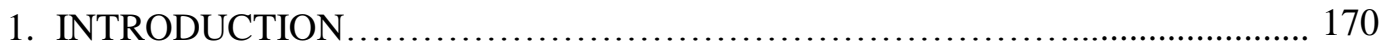

2. MATERIALS AND METHODS ............................................. 173

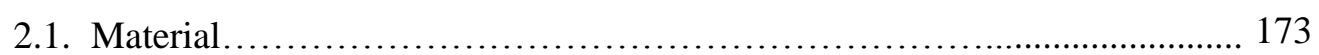

2.2. Growth medium preparation.................................................. 173

2.3. Microbial culture .................................................. 174

2.4. Microbial growth tests.................................................. 174

2.5. Growth kinetic parameters.......................................... 174

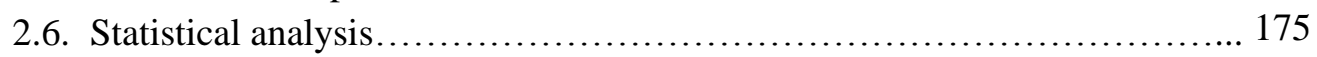

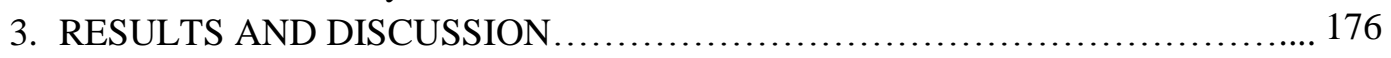

3.1. Effect of RWPS on growth curves...................................... 176

3.2. Parameters explaining the antibacterial effect of RWPS.................... 180

3.3. Comparison between microbial growth kinetic parameters...................183

3.4. Effect of RWPS on growth and inactivation kinetic parameters............ 185

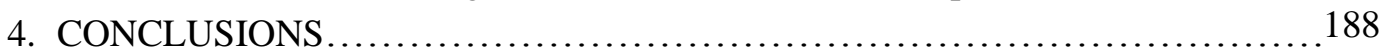

CHAPTER 5: ANTIOXIDANT EFFECT OF SEASONINGS DERIVED FROM WINE POMACE IN REFRIGERATED AND FROZEN BEEF PATTIES...........................................................193

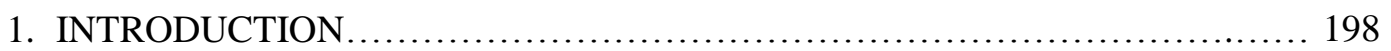

2. MATERIALS AND METHODS.......................................... 200

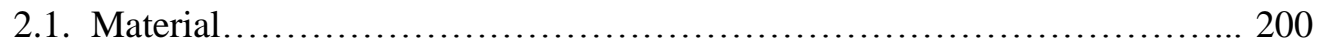

2.2. Patty preparation..................................................... 201

2.3. Thiobarbituric acid reactive substances (TBARS) analysis................ 202

2.4. Analysis of volatile organic compounds (VOCs) .......................... 203

2.5. Statistical analysis..................................................... 204

3. RESULTS AND DISCUSSION............................................ 204

3.1. Chemical analysis of beef patties....................................... 204 
3.2. Lipid oxidation under high-oxygen atmosphere and refrigeration conditions.......................................................... 204

3.3. Lipid oxidation under frozen storage of raw and cooked patties.......... 211

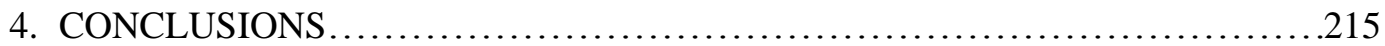

CHAPTER 6: EFFECT OF SKIN WINE POMACE AND SULFITE ON PROTEIN OXIDATION IN BEEF PATTIES DURING HIGH OXYGEN ATMOSPHERE STORAGE........................................... 219

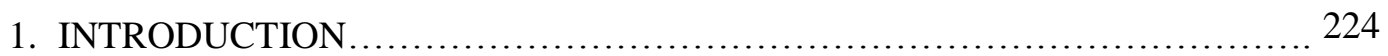

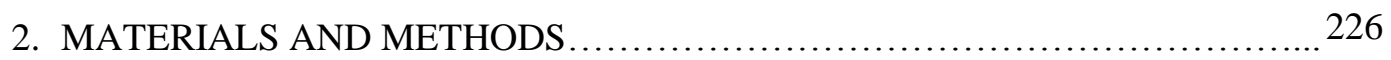

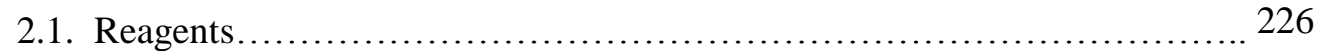

2.2. Preparation of wine pomace products................................... 226

2.3. Preparation, packaging, and storage of beef patties...................... 227

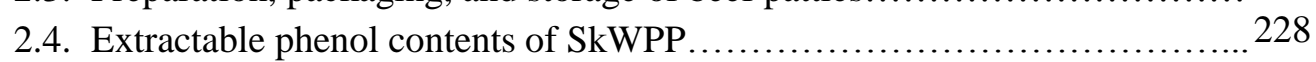

2.5. Isolation of myofibrillar proteins........................................ 229

2.6. Protein radicals by ESR Spectroscopy ................................... 229

2.7. Protein thiol groups..................................................... 230

2.8. SDS-PAGE for analysis of protein cross-linking......................... 230

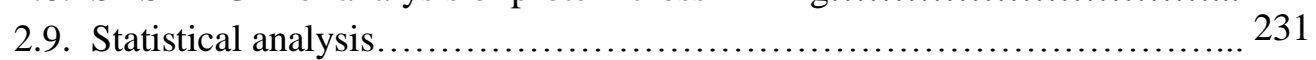

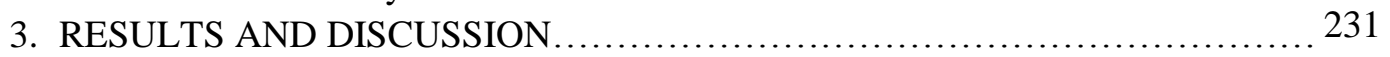

3.1. Extractable phenol contents of SkWPP ................................. 231

3.2. Protein radical formation............................................ 232

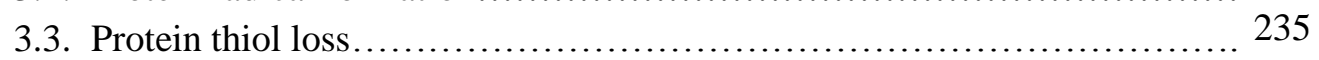

3.4. Characterization of protein cross-linking .............................. 238

3.5. Quantification of protein-cross-linking................................. 242

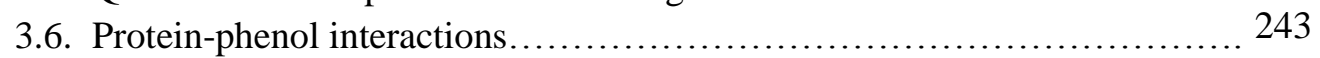

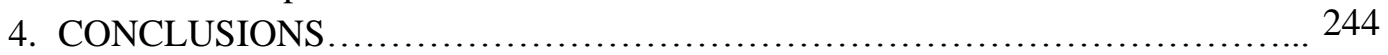

CHAPTER 7: EFFECT OF RED WINE POMACE SEASONING ON THE FORMATION OF MEAT COOKING CARCINOGENS IN BEEF

PATTIES BEFORE AND AFTER STORAGE ......................... 249

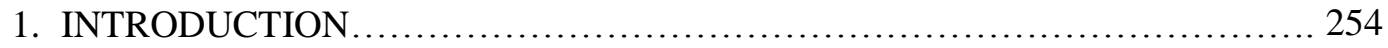

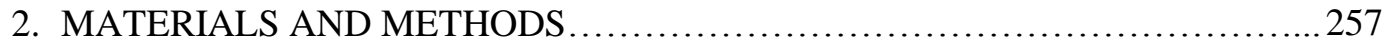

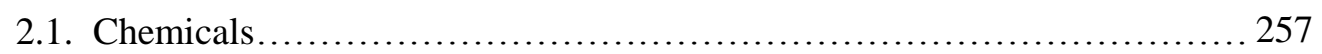

2.2. RWPS preparation................................................ 258

2.3. Patty preparation and cooking ..................................... 258

2.4. ABTS assay ......................................................... 260

2.5. Extraction and quantification of PAHs................................. 260

2.6. Extraction and quantification of HAs..................................... 261

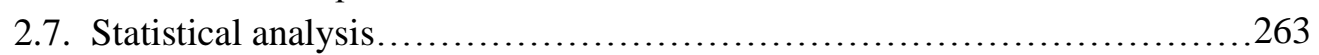

3. RESULTS AND DISCUSSION ............................................ 263

3.1. Effect of seasoning and storage on total antioxidant capacity of raw patties. 263

3.2. Patty composition, cooking temperature and cooking loss................ 264

3.3. Effect of RWPS on PAHs formation in barbecued beef patties before and after storage. 
3.4. Effect of RWPS on HAs formation in barbecued beef patties before and after storage.

4. CONCLUSIONS

CHAPTER 8: EFFECT OF RED WINE POMACE SEASONING ON THE FORMATION OF MEAT COOKING CARCINOGENS IN BEEF PATTIES BEFORE AND AFTER STORAGE ............................ 275

1. INTRODUCTION ........................................................... 280

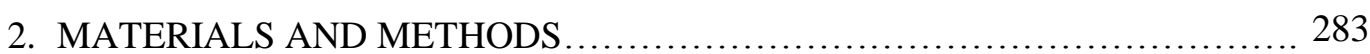

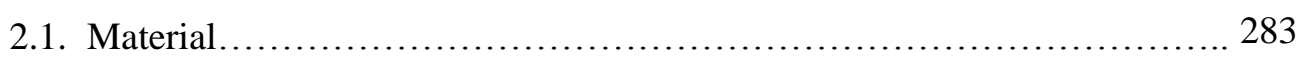

2.2. Preparation and cooking of samples.................................. 283

2.3. Determination of pyrazine contents................................... 284

2.4. Odor profile analyzed by electronic nose............................... 285

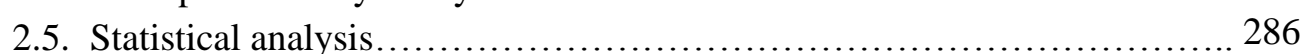

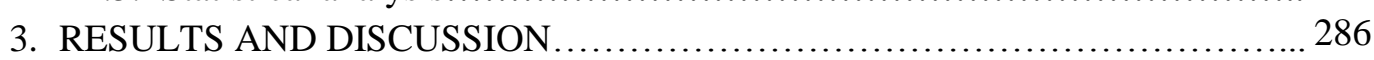

3.1. Effect of the new seasoning on the formation of pyrazines.................. 286

3.2. Possible mechanisms explaining the pyrazine-promoting effect............. 290

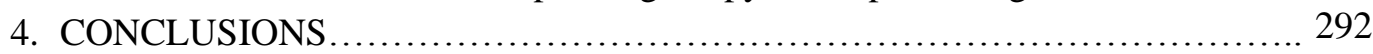

CONCLUSIONES FINALES/FINAL CONCLUSIONS....................297

LIST OF PUBLICATIONS..............................................303 


\section{CONTEXTUALIZACIÓN Y OBJETIVOS}

\section{CONTEXTUALIZATION AND AIMS}





\section{CONTEXTUALIZACIÓN Y OBJETIVOS}

Todas las regiones vitivinícolas, como es el caso de Castilla y León, deben afrontar el hecho de que junto al factor positivo de la gran contribución al PIB y al desarrollo socio-económico de las mismas, la industria vitivinícola genera algunos inconvenientes como las grandes cantidades de orujo de uva en cortos periodos de tiempo. En la actualidad, este subproducto se utiliza para obtención de alcohol en destilerías, alimentación animal, fertilizante orgánico o es desechado directamente a vertedero. Estas soluciones no explotan completamente las propiedades y características de este subproducto y en muchos casos las bodegas deben cubrir los gastos de transporte sin obtener beneficio económico. En las últimas décadas, se ha descrito que estos subproductos presentan un contenido elevado en nutrientes como fibra, minerales, ácidos grasos esenciales así como compuestos bioactivos, principalmente compuestos fenólicos. Estos compuestos no son extraídos durante el proceso de vinificación, permanecen retenidos en el orujo y pueden todavía incorporarse en la cadena alimentaria. De esta forma existen, al menos potencialmente, diversas opciones para la revalorización del orujo de vinificación, lo que proporcionaría a las bodegas, además de la posibilidad de ahorrar costes en la producción, nuevas fuentes de ingreso así como de diversificación de sus productos.

Por otra parte, la industria alimentaria está en constante búsqueda de nuevos ingredientes que le permitan mantener intacta la calidad y la seguridad de los alimentos además de prolongar su vida útil. Los aditivos sintéticos han sido ampliamente utilizados por la industria alimentaria con este fin. En general, tienen eficacia elevada y precio relativamente bajo. Sin embargo, la legislación es cada vez más restrictiva en el uso de estos aditivos y el consumidor es cada vez más reacio a su consumo, prefiriendo 
ingredientes "naturales", pero sin renunciar a la calidad de los alimentos ni a una vida útil prolongada.

La sal, más allá de su contribución al sabor de los alimentos, es un conservante tradicional, por lo que al ser añadida a los alimentos contribuye a su estabilidad microbiana. Sin embargo, el consumo excesivo de sodio se ha relacionado con la elevada prevalencia de hipertensión y otras enfermedades cardiovasculares en las poblaciones occidentales.

La reducción en el uso de sal y de aditivos sintéticos supone un reto para la industria cárnica ya que conllevan una reducción de la vida útil de sus productos y puede comprometer su seguridad alimentaria, debido a un mayor crecimiento microbiano y desarrollo de alteraciones químicas. Por otra parte, la mayor inestabilidad de los alimentos conlleva un aumento en la cantidad de desperdicios generados, con las consiguientes pérdidas económicas y problemas medioambientales asociados. En los productos cárnicos este problema es aún más relevante debido al gran gasto que supone la producción animal en términos económicos, energéticos y de contaminación ambiental. Para evitar este problema, se ha propuesto el uso de diferentes productos bioactivos naturales, con capacidad antimicrobiana y antioxidante, esencialmente de origen vegetal (extractos de plantas, especias, etc.). Muchos de estos productos además son útiles para dar respuesta a la demanda de los consumidores que buscan nuevos alimentos funcionales, es decir que aporten un beneficio adicional positivo a su salud. Uno de los enfoques más utilizados en el diseño de alimentos funcionales es el de enriquecimiento o incorporación de nutrientes y sustancias beneficiosas para la salud deficitarias en las dietas comunes., como pueden ser fibra, minerales y antioxidantes. 
Este es el escenario en el que se enmarca la presente tesis, cuyo objetivo principal será el desarrollo de propuestas de aprovechamiento integral del orujo de vinificación en tinto que permitan la obtención de nuevos ingredientes alimentarios naturales con actividad antimicrobiana y antioxidante. Complementariamente, se pretende que los nuevos productos sean capaces de paliar la inestabilidad asociada a la reducción de los niveles de sal de los alimentos, evitando poner en riesgo la seguridad de los mismos.

De esta forma, se pretende contribuir al desarrollo de una producción más sostenible a lo largo de la cadena alimentaria, incorporando el aprovechamiento de residuos de la industria alimentaria, en concreto de las bodegas, a la elaboración de alimentos, concretamente hamburguesas, con menos aditivos sintéticos pero seguros y estables en el tiempo, reduciendo así el volumen de alimentos de destrío. Esto supondrá menores costes de producción, menos daños al medio ambiente y, además, podría contribuir al bienestar social a través de la obtención de alimentos saludables.

La consecución del objetivo principal de esta tesis se ha llevado a cabo a través del desarrollo de diversos objetivos particulares más concretos como son:

$>$ Recopilación de información sobre las diferentes alternativas para aprovechar los subproductos de la vinificación en la industria alimentaria.

\section{(Capítulo 1).}

Desarrollo de una nueva propuesta de aprovechamiento integral de los orujos de vinificación obteniendo productos aptos para su uso en la industria alimentaria. (Capítulo 2).

$>$ Estudio de la capacidad de los productos elaborados para conservar y preservar la calidad de los alimentos a través de la evaluación de: la 
capacidad antimicrobiana (Capítulos 3 y 4); la inhibición de reacciones de oxidación (Capítulos 5 y 6); la capacidad inhibitoria de formación de algunos tipos de los denominados nuevos contaminantes (Capítulo 7); y de la contribución a la formación de compuestos con notas aromáticas positivas para los consumidores (Capítulos 8). 


\section{CONTEXTUALIZATION AND AIMS}

Wineries contribute significantly to the socio-economic development of the wine-producing regions, however they also present some drawbacks such as the generation of large amounts of wine pomace in short periods of time. Castilla y Leon is one of the most important wine-producing regions in Spain and thousands of tons of wine pomace are generated each vintage in this territory. Nowadays, this by-product is distilled to obtain wine alcohol, transformed in products to animal feeding, composted to obtain organic fertilizer or it is directly disposed to landfill. These solutions do not exploit the full potential and characteristics of wine pomace and even some of them are not very recommendable to environment. Furthermore, in the majority of the cases, wineries have to cover the expenses caused by the management of this by-product with the final negative repercussion in their economical balance. For that reason, during decades different proposals have been developed to obtain some profit from wine pomace. This by-product presents high contents of interesting compounds such as fiber, minerals, fats and bioactive compounds, mainly phenolic compounds. All of them can be incorporated into the food chain with an adequate treatment of wine pomace. There are different potential options to revalorize wine pomace, providing wineries with new alternatives to reduce production costs and even to obtain new incomes from the new derived products.

Moreover, the food industry is constantly looking for new ingredients that could contribute to maintain adequate food quality and safety levels. Synthetic additives have been widely used in the food industry with this purpose. Generally, they present high efficacy and relatively low price. However, restrictive legislation and consumers' 
preferences are limiting their use, and the food industry is increasing the use of natural ingredients, and looking for new alternatives to extend the shelf-life of the foodstuffs.

Salt, apart from its contribution to food taste, is a traditional food preservative, due to its contribution to the microbial stability of foods. However, excessive salt consumption has been linked to high prevalence of hypertension and cardiovascular diseases in occidental populations.

The reduction of salt and synthetic additives is a challenge for the food industry since it reduces the shelf-life of foods and may compromise food safety. Furthermore, a higher instability of foods leads to an increase in food waste with the subsequent economic losses and environmental problems. In the case of meat products, these problems present high importance due to the economic, energetic and environmental impact of animal production. Therefore, to extend the shelf-life of meat products, the use of different natural bioactive products with antimicrobial and antioxidant activity, mainly from vegetal origin as plant extracts, spices, etc., has been proposed. Many of these products could also show healthy benefits, resulting more attractive to consumers. Furthermore, they could contribute to design functional foods enriched with interesting compounds such as fiber, minerals and antioxidants, in which some diets could be deficient.

In the frame of previous comments, this $\mathrm{PhD}$ thesis focuses on the development of a new integral approach of wine pomace, obtaining new natural food ingredients with antioxidant and antimicrobial activity. Complementary, the potential of new products to mitigate the instability associated to salt reduction, contributing to maintain the food safety and the shelf life of low-salt foods, was also studied. Consequently, this $\mathrm{PhD}$ thesis could contribute to the sustainable food production, showing new 
approaches in the reutilization of wine by-products into food industry, specifically on beef patties without or with low levels of synthetic additives. This would suppose lower production costs, environmental impact and it would also improve the population health through the production of functional foods.

The indicated main aim of this thesis was achieved by conducting the next partial and specific aims:

Review the previous published proposals to use winemaking by-products in the food industry (Chapter 1).

$>$ Development of integral approaches of wine pomace, obtaining suitable products for the food industry (Chapter 2).

Study of the capacity of the developed products to preserve the food quality through the evaluation of the antimicrobial activity (Chapters 3 and 4), the inhibition of oxidative reactions (Chapters 5 and 6), the inhibition of new formed contaminants (Chapter 7) and the enhancement of positive odorants (Chapter 8). 



\section{LIST OF ABBREVIATIONS}





\section{LIST OF ABBREVIATIONS}

A: anthracene.

4,8-DiMeIQx: 2-amino-3,4,8-trimethylimidazo[4,5-f]quinoxaline.

7,8-DiMeIQx: 2-amino-3,7,8-trimethylimidazo[4,5-f]quinoxalin.

ABTS: 2,2'-azinobis-3-ethylbenzothiazoline-6-sulfonic acid.

AGEs: advanced glycation end products.

AU: arbitrary units.

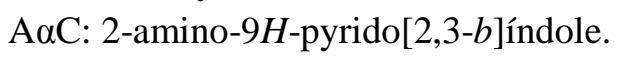

$\mathrm{BaA}$ : benzo(a)anthracene.

BaP: benzo(a)pyrene.

BbFA: benzo(b)fluoranthene.

BkFA: benzo(k)fluoranthene.

BghiP: benzo(g,h,i)perylene.

BHA: butylhydroxyanisole.

BHT: butylhydroxytoluene.

BkFA: benzo(k)fluoranthene.

CECT: colección española de cultivos tipo (Spanish Type Culture Collection).

CFU: colony-forming unit.

CHR: chrysene.

CL-MHC: cross-linked myosin heavy chain.

CML: Ne-carboxymethyl-lysine.

Cys-SH: thiol group of cysteine.

DTT: dithiothreitol

DBahA: dibenzo(a,h)anthracene.

DTNB: 5,5 dithiobis (2-nitrobenzoic acid).

ESR: electron spin resonance.

FA: fluoranthene.

GAE: gallic acid equivalent.

GC-MS: gas chromatography-mass spectrometry.

Glu-P-1: 2-amino-6-methyldipyrido[1,2- $\left.a: 3^{\prime}, 2^{\prime}-d\right]$ imidazole.

Glu-P-2: 2-aminodipyrido[1,2-a:3',2'-d]imidazole.

HAs: heterocyclic amines.

HiOx MAP: high-oxygen modified atmosphere packaging.

HPLC-DAD/FLD: high performance liquid chromatography-diode array/fluorescence detector.

HPP: hydrolysable polyphenols.

HS-SPDE: headspace solid-phase dynamic extraction.

IARC: international agency for research on cancer.

IP: indeno(1,2,3-c,d)pyrene.

ITP: index total polyphenols.

IQ: 2-amino-3-methylimidazo[4,5-f]quinolone.

IQx: 2-amino-3-methylimidazo[4,5-f]quinoxaline.

LAB: lactic acid bacteria.

LSD: least significant difference.

MAP: modified-atmosphere packaging.

MDA: malondialdehyde.

MeAaC: 2-amino-3-methyl-9H-pyrido[2,3-b]índole. 
MeIQ: 2-amino-3,4-dimethylimidazo[4,5-f]quinoline.

MeIQx: 2-amino-3,8-dimethylimidazo[4,5-f]quinoxaline.

MHC: myosin heavy chain.

MIC: minimum inhibitory concentration.

MPI: myofibrillar protein isolate.

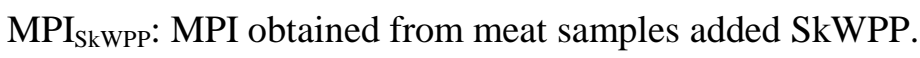

MRS: de Man Rogosa Sharpe.

NDMA: N-nitrosodimethylamine .

NEPP: non-extractable polyphenols.

NEPA: non-extractable proanthocyanidins.

NFC: neo-forrmed contaminants.

$\mathrm{PA} / \mathrm{PE}$ : polyamide/polyethylene.

PAHs: polycyclic aromatic hydrocarbons.

PCA: plate count agar.

PE/EVOH/PS: polyethylene/ethylene vinyl alcohol/polystyrene.

PETPVdC/PE: polyethylene terephthalate polyvinylidene chloride/polyethylene.

PhIP: 2-amino-1-methyl-6-phenylimidazo[4,5-b]pyridine.

PPO: polyphenol oxidase

PUFA: polyunsaturated fatty acids.

PYR: pyrene

RMSE: root mean square errors.

RP-HPLC: reversed-phase high-performance liquid chromatography

SFA: saturated fatty acid.

SD: standard deviation.

SdWPP and SdRWPS: seed wine pomace product and seed red wine pomace seasoning

SkWPP, SkRWPS and RWPS: skin wine pomace product, skin red wine pomace seasoning, red wine pomace seasoning.

t: time.

TAC: total anthocyanin content.

TAMB: total aerobic mesophilic bacteria.

TBARS: thiobarbituric acid reactive substances.

TCC: total catechin content.

TriMeIQx: 2-amino-3,4,7,8-tetramethylimidazo[4,5-f]quinoxaline.

TPAC: total proanthocyanidin content.

TPC: total polyphenol content.

Trolox: 6-hydroxy-2,5,7,8-tetramethyl-2-carboxylic acid.

Trp-P-1: 3-amino-1,4-dimethyl-5H-pyrido[4,3-b]indole.

Trp-P-2: 3-amino-1-methyl-5H-pyrido[4,3-b]indole.

TSB: tryptic soy broth.

UV: ultraviolet

VOCs: volatile organic compounds.

WP: wine pomace.

WPPs: wine pomace products

WWPP and WRWPS: whole wine pomace product and whole red wine pomace seasoning

$\lambda$ : lag time.

$\mu$ : maximum specific growth rate. 


\section{LiST OF FIGURES AND TABLES}





\section{LIST OF FIGURES}

Figure 2.1. Effect of incorporation of sulfites, skin wine pomace product (SkWPP), whole wine pomace product (WWPP) and seed wine pomace product (SdWPP) on the total aerobic mesophilic bacteria, lactic acid bacteria and Enterobacteriaceae counts of beef homogenates incubated at $37^{\circ} \mathrm{C}$.

130

Figure 3.1. Total aerobic mesophilic bacteria (TAMB) counts (mean $\pm \mathrm{SD}, \mathrm{n}=3$ ) of beef patties without additives (Control), with sulfites (300 ppm $\mathrm{SO}_{2}$ ) and with $2 \%$ $(\mathrm{w} / \mathrm{w})$ of red wine pomace seasoning (RWPS), at three different salt levels $(2 \%, 1.5 \%$ and $1 \% \mathrm{w} / \mathrm{w}$ ), packaged in high-oxygen atmosphere and stored at $4^{\circ} \mathrm{C}$, for 15 days. Horizontal lines at $7 \operatorname{logs} \mathrm{CFU} / \mathrm{g}$ indicate the criteria established for the end of the shelf-life.

151

Figure 3.2. Lactic acid bacteria $(\mathrm{LAB})$ counts (mean $\pm \mathrm{SD}, \mathrm{n}=3$ ) of beef patties without additives (Control), with sulfites $(300 \mathrm{ppm} \mathrm{SO}$ ) and with $2 \%(\mathrm{w} / \mathrm{w})$ of red wine pomace seasoning (RWPS), at three different salt levels (2\%, $1.5 \%$ and $1 \% \mathrm{w} / \mathrm{w})$, packaged in high-oxygen atmosphere and stored at $4^{\circ} \mathrm{C}$, for 15 days. Horizontal lines at $7 \operatorname{logs} \mathrm{CFU} / \mathrm{g}$ indicate the criteria established for the end of the shelf-life

157

Figure 3.3. Total aerobic mesophilic bacteria (TAMB) counts (mean $\pm S D, n=3$ ) of air-packaged beef patties without additives (Control), with sulfites (300 ppm $\mathrm{SO}_{2}$ ) or with $2 \%(\mathrm{w} / \mathrm{w})$ of red wine pomace seasoning (RWPS), at two different salt levels $(2 \%$, and $1 \% \mathrm{w} / \mathrm{w}$ ) stored at $4{ }^{\circ} \mathrm{C}$ for 6 days. Horizontal lines at $7 \operatorname{logs} \mathrm{CFU} / \mathrm{g}$ indicate the criteria established for the end of the shelf-life. ...

160

Figure 4.1. S. aureus (A) and L. innocua (B) counts (mean $\pm \mathrm{SD}, \mathrm{n}=3$ ), during incubation at $37^{\circ} \mathrm{C}$ in TSB broth supplemented with yeast extract at $\mathrm{pH}=7.2$ (Control), $\mathrm{pH} 5.2$ or 4.5 adjusted with tartaric acid and with red wine pomace seasoning (RWPS)

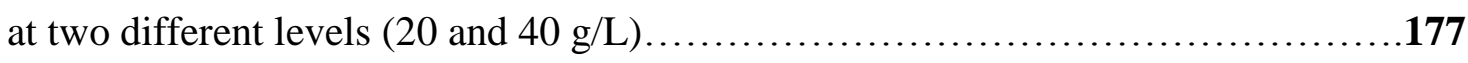

Figure 4.2. E. coli CECT 434 (A) and E. coli CECT 504 (B) counts (mean $\pm \mathrm{SD}, \mathrm{n}=$ 3 ), during incubation at $37^{\circ} \mathrm{C}$ in TSB broth supplemented with yeast extract at $\mathrm{pH}=7.2$ (Control), $\mathrm{pH} 5.2$ or 4.5 adjusted with tartaric acid and with red wine pomace seasoning (RWPS) at two different levels (20 and $40 \mathrm{~g} / \mathrm{L})$. 178

Figure 5.1. Formation of TBARS in beef patties without antioxidants (Control), with the addition red wine pomace seasonings (Seed RWPS, Whole RWPS or Skin RWPS at $2 \% \mathrm{w} / \mathrm{w})$ stored under high-oxygen atmosphere $\left(70 \% \mathrm{O}_{2} / 30 \% \mathrm{CO}_{2}\right)$ for 15 days at 4 ${ }^{\circ} \mathrm{C}$. Points show mean values of three replicates, and bars indicate standard deviations at each sampling point. .205

Figure 5.2. Formation of TBARS in beef patties without addition of any antioxidant (Control), with addition red skin wine pomace seasonings (Skin RWPS at 2\% w/w) or sulfites $(300 \mathrm{ppm})$ stored in high-oxygen atmosphere $\left(70 \% \mathrm{O}_{2} / 30 \% \mathrm{CO}_{2}\right)$ for 15 days at $4{ }^{\circ} \mathrm{C}$ in two independent experiments ( $\mathrm{A}$ and $\mathrm{B}$ ). Points show mean values of three replicates, and bars indicated standard deviation at each sampling point .206 
Figure 5.3. Formation of hexanal in beef patties without addition of antioxidants (Control), with the addition of skin red wine pomace seasoning (SkRWPS at 2\% w/w) or with addition of sulfites $(300 \mathrm{ppm})$ stored under high-oxygen atmosphere $(70 \%$ $\mathrm{O}_{2} / 30 \% \mathrm{CO}_{2}$ ) for 15 days at $4{ }^{\circ} \mathrm{C}$ in two independent experiments ( $\mathrm{A}$ and $\mathrm{B}$ ). Results are expressed in Arbitrary Units (AU). Points show mean values of three replicates, and bars indicated standard deviations at each sampling point.

.208

Figure 5.4. Formation of five volatile organic compounds: 1-pentanol, 1-hexanol, 1octen-3-ol, 2,3-octanedione and 2-pentylfuran in beef patties without addition of antioxidants (Control), with the addition of skin red wine pomace seasoning (SkRWPS at $2 \% \mathrm{w} / \mathrm{w})$ or with the addition of sulfites $(300 \mathrm{ppm})$ stored in high-oxygen atmosphere $\left(70 \% \mathrm{O}_{2} / 30 \% \mathrm{CO}_{2}\right)$ for 15 days at $4{ }^{\circ} \mathrm{C}$. Results are expressed in Arbitrary Units (AU). Points show mean values of three replicates, and bars indicate standard deviations at each sampling point.

209

Figure 5.5. Formation of TBARS in raw and cooked beef patties without addition of antioxidants (Control), with the addition of sulfites (300 ppm $\mathrm{SO}_{2}$ ) or skin red wine pomace seasoning (SkRWPS, $2 \% \mathrm{w} / \mathrm{w}$ ) stored in vacuum packaging for 6 months at $18{ }^{\circ} \mathrm{C}$. Points show mean values of three replicates, and bars indicate standard deviations at each sampling point.

Figure 5.6. Formation of Hexanal in raw and cooked beef patties without addition of antioxidants (Control), with the addition of sulfites (300 ppm $\mathrm{SO}_{2}$ ) or skin red wine pomace seasoning (SkRWPS, 2\% w/w) stored in vacuum packaging for 6 months at $18{ }^{\circ} \mathrm{C}$. Results are expressed in Arbitrary Units (AU). Points show mean values of three replicates, and bars indicate standard deviations at each sampling point 213

Fig. 6.1. ESR spectra of myofibrillar protein isolates (MPI) extracted from beef patties without addition of any antioxidant (Control) or with addition of sulfites (300 ppm $\mathrm{SO}_{2}$ ), red or white skin wine pomace product (SkWPP, $2 \% \mathrm{w} / \mathrm{w}$ ) stored in high-oxygen atmosphere for 15 days at $4{ }^{\circ} \mathrm{C}$. Left panel: representative ESR spectra obtained from freeze dried myofibrillar protein isolate. Right panel: ESR spectrum of MPI from A) control beef patties compared to patties added sulfites (spectra amplified by 1.7). B) beef patties added red SkWPP compared to control beef patties (spectra amplified by 1.3). C) beef patties added white SkWPP compared to beef patties added red SkWPP (spectra amplified by 1.7 ).

Figure 6.2. Protein radical intensity (mean $\pm \mathrm{SD}, \mathrm{n}=3$ ) of myofibrillar protein isolates (MPI) extracted from beef patties without addition of any antioxidant (Control), with addition of sulfites (300 ppm $\mathrm{SO}_{2}$ ), or with addition of red or white skin wine pomace product (SkWPP, 2\% w/w) stored for 15 days in high-oxygen atmosphere at $4{ }^{\circ} \mathrm{C}$ as determined by ESR spectroscopy 234

Figure 6.3. Protein thiol concentration (mean $\pm S D, n=3$ ) in myofibrillar protein isolates (MPI) extracted from beef patties without addition of any antioxidant (Control) 
or with addition of sulfites (300 ppm $\left.\mathrm{SO}_{2}\right)$, red or white skin wine pomace product (SkWPP, $2 \% \mathrm{w} / \mathrm{w})$ stored in high-oxygen atmosphere for 15 days at $4{ }^{\circ} \mathrm{C}$.

Figure 6.4. Representative SDS-Gel of MPI from beef patties (C), added sulfites (S), red $(\mathrm{R})$ and white $(\mathrm{W})$ skin wine pomace product packaged in high-oxygen atmosphere $\left(70 \% \mathrm{O}_{2} / 30 \% \mathrm{CO}_{2}\right.$ ) and stored for 0,8 and 15 days at $4{ }^{\circ} \mathrm{C}$. Myosin heavy chain (MHC), cross-linked MHC (CL-MHC), and actin are indicated on the gel, as well as unidentified proteins 1,2 , and 3. Samples from day 0 and 15 were run in the central lanes of the gel to ensure the highest quality in protein separation of these samples...239

Figure 6.5. Percentage volume (mean $\pm S D, n=3$ ) of cross-linked myosin heavy chain (CL-MHC) (upper panel) and myosin heavy chain (MHC) (lower panel) separated by SDS-PAGE in control beef patties (C), and beef patties added sulfite (300 ppm $\mathrm{SO}_{2}$ ), red or white skin wine pomace product (SkWPP, 2\% w/w) stored for 0, 8 and 15 days in high-oxygen atmosphere packaging $\left(70 \% \mathrm{O}_{2} / 30 \% \mathrm{CO}_{2}\right)$ at $4{ }^{\circ} \mathrm{C}$. Values are means of three independent replicates.

Figure 6.6. Percentage volume (mean $\pm \mathrm{SD}, \mathrm{n}=3$ ) of cross-linked myosin heavy chain (CL-MHC) (upper panels) and myosin heavy chain (MHC) (lower panels) separated by SDS-PAGE in control beef patties (left panels), and beef patties added red skin wine pomace product (SkWPP, 2\% w/w) (right panels) stored for 0, 8 and 15 days in highoxygen atmosphere packaging $\left(70 \% \mathrm{O}_{2} / 30 \% \mathrm{CO}_{2}\right)$ at $4{ }^{\circ} \mathrm{C}$. Solid lines correspond to non-reduced samples and dotted lines correspond to samples previously reduced by DTT. Values are means of three independent replicates

Figure 8.1. Scheme of sampling preparation .284

Figure 8.2. Odor profile of the two different batches of beef patties barbecued without (control) or with red wine pomace seasoning (RPWS), evaluated by the response intensity $\left(\left(\mathrm{R}_{0}-\mathrm{R}\right) / \mathrm{R}_{0}\right)$ of 11 sensors from an $\alpha$-FOX electronic nose.

.289

Figure 8.3. Reaction pathways proposed to explain the higher formation of pyrazines exerted by polyphenols of the studied seasoning.... 



\section{LIST OF TABLES}

Table 1.1. Products fortified with wine pomace products found in bibliography .64

Table 2.1. Proximate composition of skin wine pomace product (SkWWP), whole wine pomace products (WWPP) and seed wine pomace product (SdWPP)

.122

Table 2.2. Phenolic composition of untreated, UV-treated, thermally treated wine pomace products

Table 2.3. Microbial load of untreated, UV-treated and thermal-treated treated wine pomace products ${ }^{\mathrm{a}}$. Results are expressed as $\log \mathrm{CFU} / \mathrm{g}$ of each product.

125

Table 2.4. Protection factor of wine pomace products in olive oil and pork lard measured by Rancimat method.

129

Table 3.1. Water activity of beef patties prepared with and without red wine pomace seasoning (RWPS) at different salt levels

Table 3.2. Ash, sodium, potassium contents and sodium-potassium ratio ( $\mathrm{Na} / \mathrm{K}$ ratio) of beef patties prepared without (control) and with red wine pomace seasoning (RWPS). .155

Table 4.1. Lag phase ( $\lambda$, hours) \pm standard error of foodborne pathogens incubated at $37^{\circ} \mathrm{C}$ in TSB broth supplemented with yeast extract at $\mathrm{pH}=7.2$ (Control), at $\mathrm{pH} 5.2$ adjusted with tartaric acid and with red wine pomace seasoning (RWPS) at $20 \mathrm{~g} / \mathrm{L..183}$

Table 4.2. Maximum specific growth rate $(\mu, \log (\mathrm{CFU} / \mathrm{mL}) / \mathrm{h}) \pm$ standard error of foodborne pathogens incubated at $37^{\circ} \mathrm{C}$ in TSB broth supplemented with yeast extract at $\mathrm{pH}=7.2$ (Control), at $\mathrm{pH} 5.2$ adjusted with tartaric acid and with red wine pomace seasoning (RWPS) at $20 \mathrm{~g} / \mathrm{L}$.

184

Table 4.3. Root mean square error (RMSE) values of the growth curve adjusted in each model in foodborne pathogens incubated at $37^{\circ} \mathrm{C}$ in TSB broth supplemented with yeast extract at $\mathrm{pH}=7.2$ (Control), at $\mathrm{pH} 5.2$ adjusted with tartaric acid and with red wine pomace seasoning (RWPS) at $20 \mathrm{~g} / \mathrm{L}$

185

Table 7.1. Chemical composition and cooking loss of beef patties raw and cooked without red wine pomace seasoning (control) or with red wine pomace seasoning (RWPS)

.265

Table 7.2. PAHs content in barbecued beef patties without seasoning (control) and with seasoning $(2 \% \mathrm{w} / \mathrm{w})$ at day 0 and day 9 storage at high-oxygen atmosphere....266

Table 7.3. HAs content (ng/g) in barbecued beef patties without seasoning (control) and with seasoning $(2 \% \mathrm{w} / \mathrm{w})$ at day 0 and day 9 storage at high-oxygen atmosphere. 
Table 8.1. Pyrazines commonly found in meat products and their published flavor characteristics................................................................281

Table 8.2. Concentration (mean $\pm \mathrm{SD}$ ) of five pyrazines ( $\mathrm{ppb}$ ) in barbecued beef patties without (Control) and with Red Wine Pomace Seasoning (RWPS) ...............287 


\section{Chapter 1:}

Applications of Wine Pomace in the FoOd INDUSTRY: APPROACHES AND FUNCTIONS 



\section{Presentación}

La generación de residuos es uno de los mayores hándicaps de la producción de alimentos sostenibles, ya que entrañan un riesgo medioambiental y su adecuada gestión supone inversiones que pueden repercutir de forma relevante en el coste global de producción.

El orujo de uva es el residuo vitivinícola principal y su gestión supone, en muchos casos, un gasto considerable para las bodegas. Esta situación se debe, entre otros factores, a la falta de un aprovechamiento integral de este subproducto que genere suficiente valor añadido como para revalorizarlo. La búsqueda de alternativas se viene realizando desde hace décadas, aunque hoy por hoy sigue siendo un problema por resolver.

Este capítulo presenta una revisión bibliográfica de las propuestas de aprovechamiento del orujo de vinificación dentro de la propia industria alimentaria.

\section{Resultados más relevantes}

Las opciones para la reutilización del orujo de vinificación en la industria alimentaria son muy variadas, predominando la obtención de extractos de distinta naturaleza (aceite, pigmentos, taninos, etc.) frente a propuestas de uso integral. Las aplicaciones más frecuentes se relacionan con el aporte de compuestos antioxidantes, seguido del aporte de fibra y la acción antimicrobiana. Los alimentos en los que más se han incorporado son productos cárnicos y pesca seguidos por cereales y lácteos. 



\title{
Chapter 1. Applications of Wine Pomace in the Food Industry:
}

\section{Approaches and Functions}

\begin{abstract}
Winemaking process generates large amounts of wine pomace. This by-product has attracted the attention of food scientists and the food industry, due to its high content in nutrients and bioactive compounds. This review mainly focuses on the different published approaches to the use of wine pomace and its functions in the food industry. The predominant approach consists of different extracts, while non-extracted products, such as flours, are currently in a minority. The most common functions associated with wine pomace products are their use as antioxidants, followed by their use as fortifying agents and as antimicrobials. These products have mainly been applied to the preparation of meat and fish products and, to a lesser extent, to cereal products.
\end{abstract}

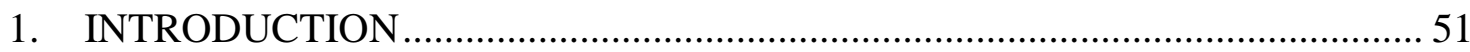

2. COMPOSITION OF WINE POMACE …............................................................ 52

2.1. Water content and microbial stability ...................................................... 53

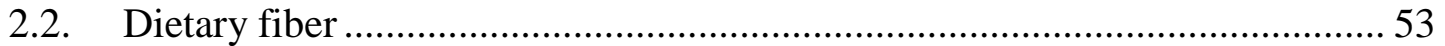

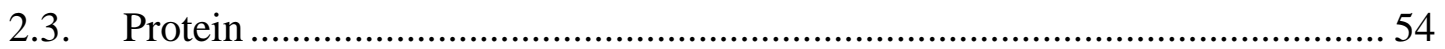

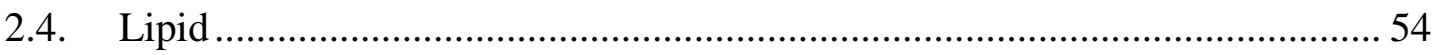

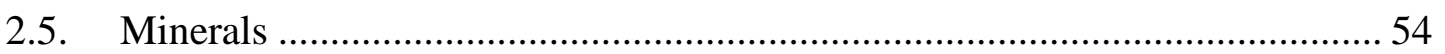

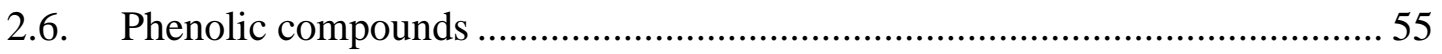

3. APPROACHES IN THE APPLICATIONS OF WINE POMACE IN THE FOOD

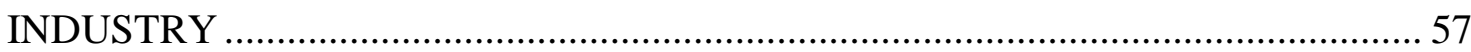

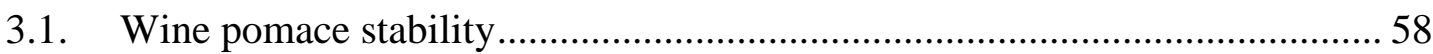

3.2. Products obtained from wine pomace ......................................................... 59

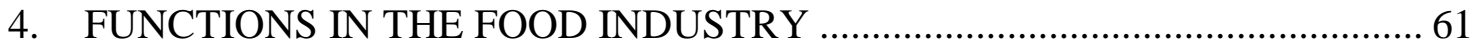

4.1. Improvement of nutritional properties and possible health effects.................61 61

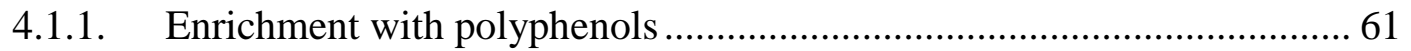


4.1.2. Enrichment with fiber.................................................................67

4.1.3. Fortification with minerals .............................................................6 67

4.1.4. Improvement of fatty acid profile ......................................................68

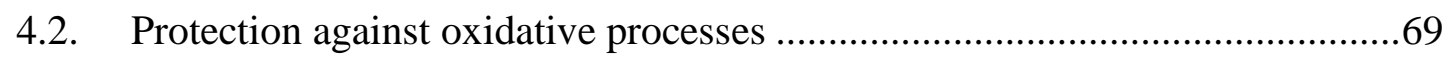

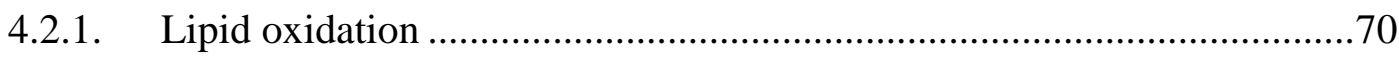

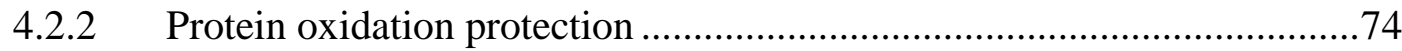

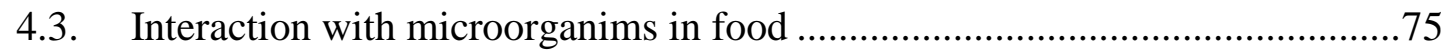

4.3.1. Antimicrobial action against food spoilage microorganisms ..................75

4.3.2. Antimicrobial action against foodborne pathogens .................................77

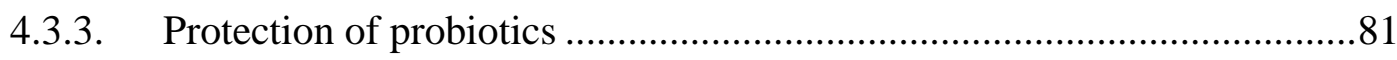

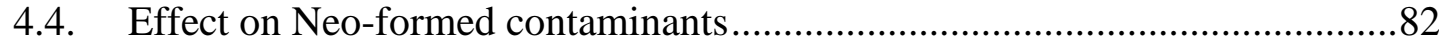

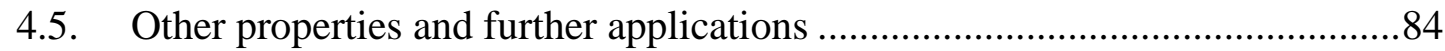

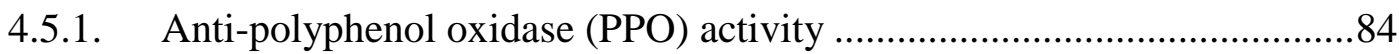

4.5.2. Reduction of residual nitrites and Nitrosamines ....................................85

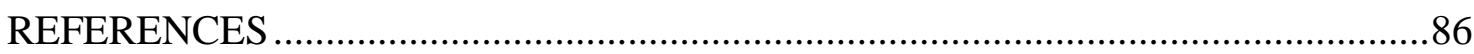




\section{INTRODUCTION}

Grapes are one of the most extensively cultivated crops in the world with almost 63 million tons produced worldwide (FOAOSTAT, 2013), the vast majority of the total grape production (75\%) is used to produce wine. Approximately $20 \%$ of the grape by weight constitute the main winemaking by-product, the grape or wine pomace (Laufenberg et al., 2003). Wine pomace is the residue of pressed grapes, small pieces of stalks and yeasts from the wine fermentation process.

Wine pomace has for a long time been an undervalued product due to a lack of alternative uses with economic benefits. Traditionally, wine pomace has been distilled to produce "wine alcohol", incorporated in many spirits, liquors and liqueurs, fortified wines, and so on. Other traditional applications of wine pomace have been its use as fertilizer or as animal feed (Arvanitoyannis et al., 2006). However, these solutions present some drawbacks mainly related to the presence of anti-nutritive compounds that can negatively affect crop yields and animal weight gain. In addition, they fail to exploit the full potential market of this by-product (Dwyer et al., 2014).

The idea of revalorizing wine pomace is not new and different alternatives have been proposed since the nineteen-seventies. All of them have focused on the exploitation of the interesting compounds retained in the wine pomace. The production of "oenocyanine" was probably one of the first interesting proposals with international acknowledgement in the food industry as well as in the pharma and the cosmetic industries. So much so that there are currently diverse commercial "oenocyanines" (anthocyanins isolated from red wine pomace) and those used in food industry are recognized as the food colorant E-163. Alongside this product, other alternatives have been developed, although none of them have had the same success as oenocyanins. For example, proanthocyanins extracted from grape seeds have been also commercialized 
in France since 1970 (e.g. Endotelon), but with medical applications, and even nowadays the use of similar products in the food industry is not usual. Grape seed oil has been also produced for decades, but neither the food industry nor consumers have made extensive use of it, despite its interesting properties (Matthäus, 2008).

Up until the end of the nineties, practically all alternatives included extraction processes followed by concentration and separation processes, in order to obtain products containing specific compounds. However, over the past few decades, other alternatives to avoid extraction phases have been proposed to the use of minimal processed wine pomace derivative products (Cheng et al., 2007; Duque et al., 2011; García-Lomillo \& González-Sanjosé, 2013; Jang et al., 2015; Martin-Carron et al., 1997). Considering the previous comments, the aim of this work is to review the most interesting proposals to revalorize wine pomace by promoting the development of products for the food industry.

\section{COMPOSITION OF WINE POMACE}

The composition of grapes may vary depending on extrinsic parameters such as edaphoclimatic conditions (Kliewer, 1977) and viticulture practices (Freeman et al., 1979), as well as intrinsic parameters such as variety, maturity and sanitary stages (González-San José et al., 1990; Gonzalez-San Jose et al., 1990; González-SanJosé \& Diez, 1993; González-SanJosé et al., 1986; Philip \& Kuykendall, 1973; Robredo et al., 1991). Similarly, both the type and the conditions under which the winemaking process is carried out notably influence the composition of wines (Gonzalez-San Jose et al., 1990; Pérez-Magariño \& González-SanJosé, 2000). Variability between grape varieties and the different effects of each winemaking process on the composition of wine explain the variations reported in the literature on the composition of wine pomace and its main components skins and seeds. Furthermore, it is important to note that red wine 
pomace is a by-product that has been fermented, while white wine pomace is removed before fermentation. Consequently, fermentable sugars remain in both white and rosé wine pomace.

\subsection{Water content and microbial stability}

Depending on the origin and the intensity of the pressure applied in the pressing process, wine pomace will present important differences in its water content, ranging between 55 and $75 \%$. Despite these possible differences, its water content is in all cases sufficient to promote microbial and enzymatic degradation (González-Centeno et al., 2010), which may compromise the subsequent application of fresh pomace.

The presence of microorganisms in wine pomace has been poorly studied. Available data indicate relatively low values of spoilage microorganism, with counts of total aerobic mesophilic bacteria (TAMB) ranging between 3 and 6 logs colonyforming units (CFU) per gram and loads between 3 and 6 logs CFU/g of yeast and molds (Augustine et al., 2013; Ayed et al., 1999; Özlem et al., 2014).

\subsection{Dietary fiber}

Dietary fiber is the main component of dried wine pomace, with concentrations ranging between 43 and $75 \%$. Dietary fiber is mainly constituted by cell wall polysaccharides and lignin. Generally, seeds are richer in fiber than skin wine pomace, and red wine pomace is richer than white wine pomace (Gül et al., 2013). Saura-Calixto et al. (1991) reported that insoluble dietary fiber (especially Klason lignin) is the main component of dietary fiber in both red and white pomace. Moreover, the fiber contains a considerable proportion of tannins and proteins (Arnous \& Meyer, 2008). 


\section{CHAPTER 1}

\subsection{Protein}

The protein content of wine pomace may range between $6 \%$ and $15 \%$ dry matter depending on grape variety and harvesting conditions; skin wine pomace being slightly richer than seed. Wine pomace present similar aminoacid profile than cereals, being rich in glutamic acid and aspartic acid and deficient in tryptophan and sulfur-containing aminoacids. Proteins from skin, but not grape seed, are also rich in alanine and lysine (Igartuburu et al., 1991a; Igartuburu et al., 1991b). Recently, Gazzola et al. (2014) published a complete characterization of the proteins present in grape seeds.

\subsection{Lipid}

The major lipid contribution in wine pomace is from the seeds. Grape seeds present high lipid contents ranging between 14 and 17\% (Gül et al., 2013; Mironeasa et al., 2016). Furthermore, the lipid fraction presents an interesting fatty acid profile rich in polyunsaturated fatty acids (PUFA) and monounsaturated fatty acids, with low levels of saturated fatty acid (SFA). Linoleic acid (C18:2) ( 70\%), oleic acid (C18:1) ( 15\%) and palmitic acid $(\sim 7 \%)(\mathrm{C} 16: 0)$ are the predominant fatty acids in the seed oil (Fernandes et al., 2013).

\subsection{Minerals}

The mineral content of wine pomace may present even wider variations than in the case of the other components, due to the strong influence of the edaphoclimatic conditions, viticultural practices, and the winemaking process (Lachman et al., 2013; Ortega-Heras et al., 1999; Taylor et al., 2003). The type and mainly the duration of maceration processes have a strong influence on the extraction and re-absorption of minerals during the winemaking processes, notably affecting the mineral content remaining in wine pomace (Ribéreau-Gayon et al., 2006). 
Minerals in grapes are usually classified in groups depending on their mobility in phloem. Potassium, phosphorous, sulfur and magnesium show high mobility and are accumulated and mainly localized in the skins of the grape berry during berry ripening. In consequence, grape skins present higher levels than grape seeds, mainly due to their high content of potassium salts localized in grape skins, specifically in the hypodermal cells (Rogiers et al., 2006). In contrast, seeds are the strongest sinks of calcium, phosphorous, sulfur and magnesium (Coombe, 1987).

\subsection{Phenolic compounds}

The phenolic composition of wine pomace has been extensively described in the bibliography (Kammerer et al., 2004; Peralbo-Molina \& Luque deCastro, 2013; Teixeira et al., 2014), with notable qualitative and quantitative differences. The large dispersion of published data is directly correlated with two well-known facts: the strong influence of all the factors that affect grape compositions (cited previously) on the phenolic profile of grapes (Andrades Rodríguez \& González San José, 1995; PérezMagariño et al., 1999) and the effect of diverse oenological practices on the extraction of phenolic compounds during the winemaking process (Pérez-Magariño et al., 2009; Revilla \& González-SanJosé, 2002).

Phenols are usually classified according to their chemical structure and molecular weight in the following groups: simple phenols (mainly C6-C1 and C6-C3), flavonoids (C6-C3-C6 and oligomers), polymeric compounds (including hydrolysable and condensed tannins, lignin, etc.) and miscellaneous phenol groups with very different structures (xanthones, stilbenes, betacyanines, etc.) (Harborne, 1964). 


\section{CHAPTER 1}

According to the literature, wine pomace retains significant quantities of different phenolic compounds. Regarding simple phenols, red skins are generally richer in phenolic acids than white skins. Grape skins are rich in hydroxyl-cinnamic acids (C6-C3) and especially rich in tartaric esters of these acids, mainly caftaric acid and coutaric acid followed by fertaric acid. Seeds are rich in gallic acid and protocatechuic acid (Kammerer et al., 2004; Teixeira et al., 2014). The presence of tartaric ester in the skins is probably associated with the remains of pulp sticking to them, as pulp generally presents the highest levels of those types of compounds (Kammerer et al., 2004; Lee \& Jaworski, 1987).

Flavonoids are a very extensive group of phenolic compounds that include a wide range of different families or subgroups mainly differentiated by the degree of oxidation of their oxygenated heterocycle. Anthocyanins (in red pomace) and flavanols are the most abundant in wine pomace, leaving any others in a minority.

Anthocyanins are the most abundant phenolic compound in red wine pomace and are mainly present in the grape skin. According to the normal composition of red varieties (González-SanJosé \& Diez, 1987), the predominant anthocyanin is malvidin3-O-glucoside which is usually followed by peonidin-3-glucoside (Amico et al., 2008; Kammerer et al., 2004).

The absence of anthocyanins in white grapes leaves flavanols as the most abundant phenols in white wine pomace. Regardless of the type of pomace, flavanols are mainly located in the seed. Grape seeds contain $56-65 \%$ of the global flavanols of grapes as against $14-21 \%$ present in grape skins. The seeds are rich in gallo-catechins (Czochanska et al., 1979), and the presence of epigallocatechin (tri-hydroxyl-catechin) has only been described in skins (Escribano-Bailón et al., 1994). In addition, oligomers 
(from 2 to five units) and polymers of flavanols are predominant, with significant relevance of type-B proanthocyanins (Ricardo-Da-Silva et al., 1991), and a lower degree of polymerization is observed in seeds than in skins (30 against 80) (Souquet et al., 1996). Oligomers and polymers with low levels of solubility are not extracted during winemaking processes and remain in the wine pomace.

The clear relevance of quercetin 3-O-glucuronide in comparison with other flavonols has been described in the wine pomace of some specific varieties (Amico et al., 2008; Amico et al., 2004; Ruberto et al., 2007). Other authors also indicated similar quercetin 3-O-glucuronide and quercetin 3-O-glucoside values with slight differences between grape varieties (Kammerer et al., 2004).

Apart from the phenolic fraction that is easily extractable by conventional methods (aqueous-organic methods), wine pomace presents important quantities of non-extractable polyphenols (NEPP) including hydrolysable polyphenols (HPP) and non-extractable proanthocyanidins (NEPA) (Pérez-Jiménez et al., 2009). NEPA are those proanthocyanidins associated with other components of wine pomace, especially fiber. HPP are monomeric phenols bound to protein, polysaccharides or cell walls via hydrophilic/hydrophobic interactions, hydrogen bonds or covalent bonds (Brenes et al., 2008). The low solubility of these fractions means that they are not extracted during winemaking, and are left in the wine pomace.

\section{APPROACHES IN THE APPLICATIONS OF WINE POMACE IN THE FOOD INDUSTRY}

The large amounts of wine pomace obtained from the winemaking process and their potential market has led food researchers to look for new alternatives that exploit 
this by-product. Nevertheless, various factors should be considered in order to obtain satisfactory applications for the food industry.

\subsection{Wine pomace stability}

Fresh wine pomace presents a high content of water, limiting its chemical and microbiological stability. This fact is very important in view of the large amounts of wine pomace produced over short periods all of which cannot be processed. There are scarce few applications of fresh pomace limited to the ripening of some traditional Italian cheeses (Di Cagno et al., 2007; McGuigan, 2015). Hence, stabilization processes for the storage of wine pomace, to prevent degradations that could compromise the subsequent applications. Wineries usually apply high doses of sulfites to inhibit microbial and oxidative deterioration of wine pomace. Gamma irradiation in combination with other synthetic preservatives such as sulfites (Ayed et al., 1999) and sodium benzoate (Augustine et al., 2013) has also been applied to increase its shelf-life. However, different drying methods are the most common way of processing wine pomace.

Due to the low thermal stability of bioactive compounds, freeze-drying is considered to retain the highest levels of bioactive compounds in comparison to oven drying (Tseng \& Zhao, 2012). However, freeze-dried samples present the highest losses of bioactive compounds during subsequent storage, most probably caused by the porosity of freeze-dried products that increases air contact and their susceptibility to oxidation. In contrast, Larrauri et al. (1997) found no significant differences between total extractable polyphenols and condensed tannin contents of freeze-dried and oven dried (under $60^{\circ} \mathrm{C}$ ) wine pomace. However, significant decreases were observed in process at 100 and $140^{\circ} \mathrm{C}$. Interestingly, heat treatment over lengthy periods may induce the release of certain low-molecular weight compounds increasing the level of 
certain phenolic compounds (Pedroza et al., 2012; Planinic et al., 2015). Sui et al. (2014) reported the suitability of infrared drying to retain the highest bioactivity in comparison to convective drying.

\subsection{Products obtained from wine pomace}

A wide range of products has been developed in the last decades from wine byproducts over recent decades. The most common approach is by obtaining extracts using organic solvents or water for the production of enriched extracts of high interest in food applications. Extractive processes may be combined with purification and concentration steps to obtain concentrated extracts of specific compounds. Due to the high concentrations of bioactive compounds in the obtained extracts, low concentrations are needed for successful applications in food systems.

The first extracted components were probably anthocyanins, and the first commercial product "oenocyanin". The excellent coloring properties of this product enabled its use in different matrixes such as dairy desserts, ice creams, drinks, juices and other food preparations.

Grape seed oil is another successful approach and corresponds to a solvent extracted product obtained from grape seeds. However, although consumers perceive grape seed oil as a healthier alternative than other oils, this product is not widely used probably because of its high price and it is not extensively applied in food industry (Dwyer et al., 2014).

Excluding a fraction of grape seed protein with interesting solubility and emulsifying activity for application in soup, sauce, beverage and meat products (Zhou et al., 2011), wine pomace derivative products have mainly been focused on the extraction of different phenolic compounds. The influence of different parameters, 
including solvent polarity, temperature, particle solid size, ratio solid: solvent etc., on the final yield and on the composition of extracts have been studied from many years (Bonilla et al., 1999) and several reviews have described the parameters affecting polyphenol extraction in depth (Pinelo et al., 2005; Spigno \& De Faveri, 2007).

Other techniques applied to enhance extraction of polyphenols from wine pomace include enzyme attack (Meyer et al., 1998), high hydrostatic pressure and ultrasonic techniques (Corrales et al., 2008), microwaves (Krishnaswamy et al., 2013) high-voltage electrical discharges (Boussetta et al., 2009), pulse electric field (Corrales et al., 2008) and gamma irradiation (Ayed et al., 1999).

In contrast to extracts, other researchers have proposed the use of products without a previous extraction process. This approach enables a more complete reutilization of the by-products, and enables intense fortification with fiber, minerals, protein, oil and other constituents of wine pomace such as phenols, including nonextractable phenolic compounds. In this way, the nutritional value and the potential health benefits can be improved. Furthermore, since extraction is not required, the process of obtaining these powdered products is more economic and has a lower impact on the environment, resulting in a sustainable approach.

Probably, the first approach to non-extracted products was the concept known as "grape antioxidant dietary fiber" (Saura-Calixto \& García-Laurrari, 1999). This approach focused on the healthy benefits of the fiber combined with the grape antioxidant, but technological applications, mainly due to their antioxidant activity, were also proposed (Martin-Carron et al., 1997).

Different authors have also proposed the use of wine pomace flours obtained after milling whole wine pomace or their main components: seeds and skins (Hoye \& 
Ross, 2011; Mironeasa et al., 2012; Özvural \& Vural, 2011; Rosales Soto et al., 2012). Increasing consumer demands for alternatives to wheat flour and especially for flours with high fiber and mineral levels have prompted the development of these products.

\section{FUNCTIONS IN THE FOOD INDUSTRY}

The content of wine pomace in diverse compounds with different properties enables a wide range of potential functions and technological uses of this by-product. Many of these options are a consequence of the content in phenolic compounds with high bioactivity (antioxidant, antimicrobial, vitamin P effect among others). However, other components such as fiber, minerals and fat may play a relevant role in determining some of the possible functions of wine pomace products in foodstuffs.

\subsection{Improvement of nutritional properties and possible health effects}

Fortification involves the incorporation of nutrients to foods whether or not the nutrients are originally present in the food. According to its composition, wine pomace may be a source of different and interesting nutrients. Fortification with wine pomace may contribute to reducing certain nutritional problems detected in western societies, such as low average intakes of antioxidants, fiber and minerals (Flagg et al., 1995; He \& MacGregor, 2001; Marlett et al., 2002). Furthermore, the presence of beneficial compounds, i.e. phenolic compounds, may also improve its perceived value among consumers on the look out for functional foods (Morley, 2013). In fact, wine pomace products have mainly been applied to enrich foodstuffs with antioxidants.

\subsubsection{Enrichment with polyphenols}

Phenolic compounds are not considered nutrients, but many works in the bibliography have revealed their potential benefits as remarked in different reviews (Teixeira et al., 2014; Xia et al., 2010). The most commonly cited function is their 
antioxidant activity; however other capacities as antimicrobial and anti-inflammatory activities have been also indicated. Antioxidant capacity has been linked to the prevention of diseases associated with oxidative stress (Shrikhande, 2000; Teixeira et al., 2014). So, wine pomace polyphenols have been associated with anticancer activities, as they are able to induce apoptosis in tumor cell lines and may exert antiproliferative activity (Jara-Palacios et al., 2015) and avoid the formation of carcinogen-induced DNA adduct and DNA synthesis in cancer cells (Xia et al., 2010).

Generally, the health benefits of wine pomace have been associated with the consumption of the so-called extractable polyphenols. However, the contribution of extractable phenols is usually overvalued, to the detriment of NEPP. NEPP were shown to decrease cholesterol absorption and increase fat excretion (Bobek, 1999; Bravo \& Saura-Calixto, 1998; Saura-Calixto, 2012). Moreover, they are more stable and less influenced by digestion and food processing conditions than extractable polyphenols that are degraded during the process.

Limited research has been conducted to determine whether the health benefits ascribed to isolated phenols are also obtained by consuming foods enriched with wine pomace products. This fact is very interesting due to the interaction between polyphenols and matrix ingredients that may reduce the bioactivity of wine pomace phenols. Moreover, food processing may also degrade phenolic compounds, especially during high temperature processes (Surh \& Koh, 2014). Degradation during storage may also induce a relevant decrease in phenolic content. Mildner-Szkudlarz \& Bajerska (2013) reported that breads enriched with freeze-dried skin wine pomace reduced total cholesterol levels, low density lipoprotein, lipid peroxidation and increased antioxidant activity in rats with diet-induced hypercholesterolemia. Recently, grape seed extract incorporated into white bread was proposed to reduce the postprandial glycemic 
response and increase satiety (Coe \& Ryan, 2016). Grape seed extract was able to reduce sugar release from starch and glycemic response as well as increase satiety, perhaps of even greater relevance in high glycemic index foods such as white bread. There is also an increasing trend towards the utilization of fruit by-products in extruded snacks, due to the release of simple sugars during extrusion that increases the glycemic index (Rohm et al., 2015). The use of the complete product (high in fiber) rather than extracts can also contribute to a reduction in the glycemic response.

Several food categories have been successfully enriched in phenols by incorporating wine pomace products (Table 1.1.). Cereal products, mainly bread and cookies, are the category with the highest number of applications that mainly make use of wine pomace flours (Acun \& Gül, 2014; Aghamirzaei et al., 2015; Hoye \& Ross, 2011; Mironeasa et al., 2016; Munteanu et al., 2013).

Cookies incorporating seedless and wine pomace flours obtained higher values of acceptability than those made with seed flours (Acun \& Gül, 2014), whereas cereal bars were reported as an excellent option to include grape seed flour (Rosales Soto et al., 2012). However, the incorporation of wine pomace flour requires the adaptation of recipes and processing conditions to preserve the quality of baked products. Various works have noted the modifications induced by this type of flours, such as the increase of $\alpha$-amylase activity, leading to a lower falling number; and the possible interaction of seed lipids with gluten, starch and hydrophobic components resulting in weaker consistency of the dough, increased viscosity, and delayed gelatinization of starch (Mironeasa et al., 2012; Mironeasa et al., 2016). In contrast, Meral \& Doğan (2013) described contrary results such as a strengthening activity of grape seed flours, ascribed to the covalent or non-covalent bound between gluten proteins and phenols, obtaining stronger flours, with higher extensibility and resistance. 
Table 1.1. Products fortified with wine pomace products found in bibliography ${ }^{a}$

\begin{tabular}{|c|c|c|c|c|c|c|}
\hline Category & Foodstuff & $\begin{array}{c}\text { Wine pomace } \\
\text { product }\end{array}$ & Level & $\begin{array}{c}\text { Fortification } \\
\text { with }\end{array}$ & Complementary aims & $\underset{\mathrm{a}}{\text { Ref. }}$ \\
\hline \multirow{17}{*}{$\begin{array}{c}\text { Cereal } \\
\text { products }\end{array}$} & \multirow{6}{*}{ Bread } & \multirow{4}{*}{ Seed flour } & $2.5-10 \%$ & Phenols & Physical/sensory properties & 1 \\
\hline & & & $5-25 \%$ & Phenols/Fiber & Physical properties & 2 \\
\hline & & & $2.5-7.5$ & Phenols & Physical/sensory properties & 3 \\
\hline & & & $10 \%$ & $\begin{array}{l}\text { Fatty acids/ } \\
\text { Minerals }\end{array}$ & Physical/sensory properties & 4 \\
\hline & & WWP powder & $5-10 \%$ & Fiber/Phenols & $\begin{array}{c}\text { Mineral fortification } \\
\text { Physical/sensory properties }\end{array}$ & 5 \\
\hline & & SkWP powder & $4-10 \%$ & Phenols/Fiber & Physical/sensory properties & 6 \\
\hline & \multirow{6}{*}{ Biscuits } & $\begin{array}{c}\text { Seed wine } \\
\text { pomace powder }\end{array}$ & $5 \%$ & $\begin{array}{l}\text { Phenols } \\
\text { Mineral }\end{array}$ & $\begin{array}{l}\text { Prevention of lipid oxidation } \\
\text { Physical/sensory properties }\end{array}$ & 7 \\
\hline & & WWP powder & $10-30 \%$ & Phenols/Fiber & Physical/sensory properties & 8 \\
\hline & & WWP powder & $20-30 \%$ & Fiber/Protein & Physical/sensory properties & 9 \\
\hline & & $\begin{array}{l}\text { Seedles, whole } \\
\text { and seed WP }\end{array}$ & $5-15 \%$ & Fiber/Protein & Physical/sensory properties & 10 \\
\hline & & \multirow{2}{*}{$\begin{array}{c}\text { Skin wine } \\
\text { pomace powder }\end{array}$} & $5-10 \%$ & Mineral/Fiber & Sensory properties & 11 \\
\hline & & & $10-50 \%$ & Fiber/Protein & Sensory properties & 12 \\
\hline & $\begin{array}{l}\text { Bread } \\
\text { muffin }\end{array}$ & WWP powder & $5-20 \%$ & Phenols/Fiber & Physical/sensory properties & 13 \\
\hline & Muffins & SkWP powder & $20 \%$ & Phenols & Reduction of CLM & 14 \\
\hline & $\begin{array}{c}\text { Breakfast } \\
\text { cereals }\end{array}$ & WP flours & $5-20 \%$ & Phenols/Fiber & Physical/sensory properties & 15 \\
\hline & $\begin{array}{c}\text { Bars } \\
\text { Pancakes } \\
\text { Noodles }\end{array}$ & SdWP flour & $5-30 \%$ & Phenols & Sensory analysis & 16 \\
\hline & Pasta & WP extract & - & Phenols & Physical/sensory properties & 17 \\
\hline \multirow{10}{*}{$\begin{array}{c}\text { Dairy } \\
\text { products }\end{array}$} & \multirow{2}{*}{$\begin{array}{l}\text { Fermented } \\
\text { milk }\end{array}$} & WP extract & $\begin{array}{l}100 \mathrm{mg} \\
\mathrm{GAE} / \mathrm{L}\end{array}$ & Phenols & Sensory properties & 18 \\
\hline & & WP flour & $10-50 \mathrm{~g} / \mathrm{L}$ & Phenols & Fermentation kinetics & 19 \\
\hline & \multirow{4}{*}{ Yogurt } & SdWP extract & $\begin{array}{l}50-100 \\
\mathrm{mg} / \mathrm{Kg}\end{array}$ & Phenols & Physical properties & 20 \\
\hline & & $\begin{array}{l}\text { WWP powder } \\
\text { WP extract }\end{array}$ & $\begin{array}{c}1-3 \% \\
2 \% \\
\end{array}$ & Phenols/Fiber & Inhibition lipid oxidation & 21 \\
\hline & & WWP extract & $1 \%$ & Phenols & & 22 \\
\hline & & SkWP flour & $6 \%$ & Phenols & Physical/sensory properties & 23 \\
\hline & \multirow{3}{*}{ Cheese } & WWP powder & $0.8-1.6 \%$ & Phenols & Microbial/Physical properties & 24 \\
\hline & & WWP extract & $\begin{array}{c}0.5 \\
\mathrm{mg} / \mathrm{mL} \\
\end{array}$ & Phenols & Physical properties & 25 \\
\hline & & $\begin{array}{l}\text { SkWP, WWP and } \\
\text { SdWP extracts }\end{array}$ & $0.1-0.3 \%$ & Phenols & Physical properties & 26 \\
\hline & Ice cream & $\begin{array}{c}\text { Grape seed } \\
\text { extract }\end{array}$ & $0.4 \%$ & Phenol & Sensory & 27 \\
\hline \multirow{2}{*}{$\begin{array}{c}\text { Meat } \\
\text { products }\end{array}$} & Sausages & SdWP flour & $0.5-5 \%$ & Fiber & Antioxidant and sensory & 28 \\
\hline & Beef loin & Grape seed oil & $10 \%$ & Fatty acids & Enhance quality and safety & 29 \\
\hline \multirow{3}{*}{ Others } & Seafood & SkWPP powder & $3 \%$ & Fiber/Phenols & Antioxidant antimicrobial & 30 \\
\hline & Puree & SkWP powder & $3.2 \%$ & Phenols & Sensory & 31 \\
\hline & Infusions & SkWP extract & $50-100 \%$ & Phenols & Color, antiviral activity & 32 \\
\hline
\end{tabular}


Table 1.1. ${ }^{a}$ WP: wine pomace, WWP: whole wine pomace; SkWP: skin wine pomace; SdWP: seed wine pomace. References:

1 (Hoye \& Ross, 2011); 2 (Aghamirzaei et al., 2015); 3 (Meral \& Doğan, 2013); 4 (Munteanu et al., 2013); 5 (Smith \& Yu, 2015); 6 (S. Mildner-Szkudlarz et al., 2011); 7 (Aksoylu et al., 2015); 8 (S. Mildner-Szkudlarz et al., 2013); 9 (Karnopp et al., 2015); 10 (Acun \& Gül, 2014); 11 (Canett Romero et al., 2004); 12 (Mieres Pitre, 2011); 13 (Walker, 2013); 14 (Sylwia Mildner-Szkudlarz et al., 2015)

15 (Menezes Oliveira et al., 2013); 16 (Rosales Soto et al., 2012); 17 (Marinelli et al., 2015); 18 (Aliakbarian et al., 2015); 19 (Frumento et al., 2013); 20 (Chouchouli et al., 2013); 21 (Tseng \& Zhao, 2013); 22 (Karaaslan et al., 2011); 23 (Marchiani et al., 2016); 24 (Marchiani et al., 2015); 25 (Han et al., 2011); 26 (Felix da Silva et al., 2015); 27 (Sagdic et al., 2012a); 28 (Özvural \& Vural, 2011); 29 (Jung et al., 2012); 30 (Ribeiro et al., 2013); 31(Lavelli et al., 2014); 32 (Bekhit et al., 2011)

Dairy products are the second food category with significant phenol-enrichment applications using wine pomace products (Table 1.1.). In this case, the effectiveness was lower than in cereal products due to instability and loss of phenols during processing and storage of dairy products, as well as other technological problems. Tseng \& Zhao (2013) described that the addition of grape pomace flour to milk produced excessive syneresis (levels higher than 3\%) of yogurt and no coagulation was observed at levels higher than 5\%. Moreover, periods of storage as low as one week induced relevant drops in total phenolic and antioxidant activity of yogurt. Authors ascribed these results to polyphenol degradation at yogurt $\mathrm{pH}$ and to phenol-casein interactions. Loss of phenol contents over short periods were also observed by other authors (Aliakbarian et al., 2015; Karaaslan et al., 2011), and the decrease in the phenolic content was ascribed to consumption of phenols to prevent lipid oxidation (Chouchouli et al., 2013). However, Marchiani et al. (2016) noted that levels of quercetin increased during storage, probably due to its solubilization in the yogurt.

Grape seed extract was satisfactorily used in cheese manufacturing, where hydrophobic interactions between caseins and phenols contributed to phenol-retention in the curd, reducing the losses of phenolic compounds (levels in whey around 20\%) (Han et al., 2011), although the kinetics of gel formation were retarded due to the decrease in the $\mathrm{pH}$. The $\mathrm{pH}$ decrease caused by the incorporation of organic acids from 
grape pomace also induces the degradation of casein at the end of ripening of Tomalike cheeses (Marchiani et al., 2015). Similarly, the incorporation of pomace extracts and flours into milk delayed milk clotting and decreased the clotting rate and syneresis, which was explained by hydrophobic interactions between proteins and polyphenols that reduce the amount of hydrophobic groups in casein (Felix da Silva et al., 2015). An increase in syneresis was also observed (Marchiani et al., 2016). However, authors explained this observation in terms of a matrix gel rearrangement, caused by the insoluble dietary fiber of the skin flour.

Another potential limitation of wine pomace products could be their antimicrobial effect on lactic acid bacteria (LAB) growth during the fermentation. Viable counts of lactic acid bacteria should be kept above $10^{7} \mathrm{CFU} / \mathrm{g}$ during the commercial shelf-life of the product (WHO, 2011). However, the studies in the bibliography presented satisfactory results with no or little effect on microbial growth, or on the LAB survival during storage (Casarotti \& Penna, 2015; Chouchouli et al., 2013; Marchiani et al., 2016).

Other products have also been fortified with wine pomace products such as marmalade or candies (Cappa et al., 2015; Guzmán Nieves, 2011), salad dressing (Tseng \& Zhao, 2013), tomate puree (Lavelli et al., 2014). A new seafood functional sausage was also developed based on meagre (Argyrosomus regius), (Ribeiro et al., 2013) and red skin extracts were also incorporated into a tea infusion (Bekhit et al., 2011) at different concentrations, ranging between 50 and $100 \%$ in order to increase the phenolic profile and antioxidant activity of the infusions. 


\subsubsection{Enrichment with fiber}

An adequate fiber intake has been associated with the prevention of some diseases such as hypertension, diabetes and obesity (Anderson et al., 2009). Soluble dietary fiber is able to decrease glycemic responses and cholesterol levels in plasma. Since it is fermented in the large intestine, fiber improves the colonic environment. Moreover, it delays and interferes in the absorption of cholesterol and bile acids. Dietary fiber also limits carbohydrate absorption, reducing insulin response and triacylglycerol levels, which are risk factors for coronary diseases. Insoluble dietary fiber increases fecal bulk and presents benefits in terms of intestinal motility, lowering gastric emptying and promoting satiety (R. Rodríguez et al., 2006).

Non-extracted products such as wine pomace flours have mainly been used to increase the fiber content of different foods (Table 1.1.). The incorporation of these products is limited due to similar factors to those described in the previous section. Hence, the most common matrix in which these products have been incorporated is cereal products.

\subsubsection{Fortification with minerals}

Currently, the intake of minerals in western populations presents a clear deficiency in some minerals such as potassium while sodium among others are consumed in excess (EFSA, 2005). Potassium is an essential mineral, involved in the electrolyte balance and normal cell functioning, and is required to maintain muscular and neurological functions due to their role in neuromuscular excitability (Rüdel et al., 1984). Moreover, adequate potassium intakes could contribute to reduce blood pressure, decreasing stroke risk and cardiovascular diseases, especially in hypertensive populations (He \& MacGregor, 2010; Karppanen \& Mervaala, 2006). Due to its relatively high mineral content, products derived from wine pomace represent 
interesting alternatives for the fortification of foodstuffs and to increase the intake of minerals; especially of potassium, but also of calcium, magnesium, zinc, copper, manganese and phosphorus, all of which have essential functions for human health. However, the mineral composition of winemaking by-products has been often undervalued and there are no applications that focus on mineral content. Some isolated studies (two of those shown in Table 1.1.) have pointed to changes in the mineral composition of cereal products following the incorporation of wine pomace flours.

Mineral fortification is also relevant to the food industry from the technological point of view. For instance, the calcium content of seed flours may stabilize enzymes such as proteases and $\alpha$-amylases that are essential in the quality of cereal products (Mironeasa et al., 2012; Mironeasa et al., 2016)

\subsubsection{Improvement of fatty acid profile}

The high levels of grape seed oil in essential fatty acids may contribute to lowering the risk of such diseases as cardiovascular disease, diabetes, arthritis, immune disorders and cancer (Simopoulos, 1999). The current intake of saturated fatty acids are higher than recommended ( $10 \%$ of total energy), so grape seed oil can balance the PUFA/SFA ratios of human diet (Williams, 2000). Interestingly, grape seed oil is free of cholesterol (Choi et al., 2010), and is associated with antioxidants, such as phenolic compounds, tocopherols (especially $\alpha$-tocopherol) and tocotrienols.

Grape seed oil was proposed as a food ingredient (Jung et al., 2012). Apart from its previously described nutritional characteristics, grape seed oil presents interesting properties for the food industry due to its high smoking point. It has been used to reduce animal fat content in meat products, improving the nutritional properties as well reducing cooking loss and increasing protein solubility (Choi et al., 2010). The incorporation of grape seed oil (up to 10\%) was also proposed to replace beef fat and 
improve the fatty acid profile of frankfurters and beef loin steaks (Jung et al., 2012; Özvural \& Vural, 2014).

\subsection{Protection against oxidative processes}

Different food components may undergo oxidation during food storage or food processing, reducing the quality and the nutritional properties of foods. Food matrix composition (metal content, water activity, fatty acid profile, etc.), and formulation strongly affect the susceptibility of foods to oxidation (Ladikos \& Lougovois, 1990). Storage conditions such as atmosphere, light exposure and temperature play a key role in the development of oxidative processes. Furthermore, manufacturing processes such as grinding or cooking may also increase oxidative instability due to the loss of physical structure and the release of pro-oxidant compounds from the intracellular medium (Alfawaz et al., 1994; Kanner, 1994).

The food industry has traditionally used synthetic antioxidants such as butylhydroxyanisole (BHA), butylhydroxytoluene (BHT), and ascorbyl palmitate to mitigate food oxidation (Decker \& Mei, 1996). However, some of these synthetic antioxidants have been linked to different toxicological effects, including tumorpromoting activity (Kahl \& Kappus, 1993), and current food policies are increasingly restricting the use of these types of additives. Furthermore, there is an increasing consumer concern over the potential risks of chemical additives, increasing the demand for products without synthetic additives (Carocho et al., 2015). For these reasons, natural additives, and mainly alternative natural antioxidants, with similar efficacy than synthetic additives, have received high interest from the food industry. Among the natural additives, wine pomace products have been reported as an excellent alternative to synthetic antioxidants, mainly due to their high content of phenolic compounds. Different mechanisms have been used to explain the antioxidant properties exerted by 
wine pomace products: donating hydrogen atoms (Bors et al., 1990), scavenging free radicals (Kanner, 1994), quenching intermediate compounds of oxidative reactions (Kanner et al., 1994), scavenging the superoxide ion $* \mathrm{O}_{2}{ }^{-}$(Chen et al., 1990), chelating metal initiators (Galleano et al., 2010; Gülçin, 2010; Ku \& Mun, 2008), inhibiting the enzymatic activity of oxidative enzymes such as lipoxygenase (Duque et al., 2011), and the preservation of endogenous antioxidants (Pazos et al., 2005).

\subsubsection{Lipid oxidation}

Lipid oxidation is, with microbial spoilage, one of the main factors limiting the shelf-life of foodstuff, causing large loses during storage. Lipid oxidation involves two phases: primary oxidation that induces the formation of lipid hydroperoxides, diene and triene conjugates and secondary oxidation that leads to the formation of volatile compounds (Frankel, 1983). Consequently, the sensory quality deteriorates, the nutritional value is reduced (due to the destruction of nutrients such as PUFA and vitamins), and the technological properties may also be affected (Kanner, 1994). Moreover, some compounds derived from lipid oxidation, especially those from the primary oxidation, can present toxic effects.

In general terms, the literature reports that wine pomace products present stronger inhibition against the secondary lipid oxidation phase than against the primary phase (Sánchez-Alonso et al., 2006; Shaker, 2006). Although pure phenolic compounds may present interesting antioxidant activity, wine pomace products usually present higher activity than isolated compounds (Maestre et al., 2010). This fact suggests a synergistic effect between phenolic compounds. Regarding concentration, relatively low levels of wine pomace extracts are required to achieve antioxidant effect, although the published data varies depending on the type of product in use. So, different wine pomace products have been effective from levels as low as $10 \mathrm{ppm}$ until to levels as 
high as 10\% (Hasani \& Alizadeh, 2015; Rojas \& Brewer, 2007; Shirahigue et al., 2010). Generally, a low risk of pro-oxidant activities has been described, which facilitates the application of these products as antioxidants.

The antioxidant efficacy against lipid oxidation of wine pomace products has also been tested in combination with other natural extracts such as essential oils (Adams et al., 2002; Moradi et al., 2011; Tajik et al., 2015) and green tea extracts (Rababah et al., 2011a; Rababah et al., 2010), and with synthetic additives such as sulfites (Bañón et al., 2007). Generally, additive effect has been observed suggesting a synergistic effect between the different antioxidants.

Other researchers tested the potential of incorporating wine pomace products into films. This type of products present a gradual release of active compounds to the matrix and the effect is observed for longer periods (Borderías et al., 2005). Chitosan is the most commonly used material in the films due to its high versatility and its excellent film-forming properties. Furthermore, chitosan possesses relevant antioxidant and antimicrobial activity (Ulbin-Figlewicz et al., 2014). The efficiency of chitosan films were improved by the incorporation of grape seed extracts (Moradi et al., 2011). Moreover, grape seed extract was incorporated into a carboxymethyl cellulose coating with satisfactory results (Raeisi et al., 2014).

Meat and meat products are the food categories in which wine pomace products have been most widely used to prevent lipid oxidation. Meat products usually contain high levels of fat and pro-oxidants such as salt and metals. In the case of raw meat, atmospheres rich in oxygen, used to keep the red color, may also enhance lipid oxidation. Furthermore, previous processes such as grinding, mixing and cooking may also increase the oxidative instability of the products during the following storage. (Alfawaz et al., 1994; Kanner, 1994). 


\section{CHAPTER 1}

Wine pomace products have been applied in different species such as beef (Ahn et al., 2002; Ahn et al., 2007), pork (Carpenter et al., 2007; Sasse et al., 2009), chicken (Shirahigue et al., 2011), turkey (Mielnik et al., 2006), goat (Rababah et al., 2012a) and buffalo (Tajik et al., 2015) meat, usually in patties or sausages that permit an acceptable homogeneity of the product in the matrix (Liu et al., 2015; Ryu et al., 2014; Wagh et al., 2015). In the case of intact muscles (such as chicken breast, steaks, etc.), the products can be applied by pressurized tumbling (Rababah et al., 2006; Rababah et al., 2010), by rubbing the dehydrated product (Wong \& Kitts, 2002), by dipping the meat product into a solution containing the antioxidant (Vaithiyanathan et al., 2011) such as frying batters (Cagdas \& Kumcuoglu, 2014), and marinades (Gibis \& Weiss, 2012) and by spraying the antioxidant onto the surface of the meat (Camo et al., 2011). Other meat products that have been tested include liver (Pateiro et al., 2014), restructured mutton (Reddy et al., 2013), chorizo (Lorenzo et al., 2013), pâté (Pateiro et al., 2014), dry-cured bacon (Wang et al., 2015b) mortadella-type sausages (Moradi et al., 2011) and milano type salami (Mendes et al., 2014), dehydrated meat (Nissen et al., 2000), and lard (Schevey \& Brewer, 2015).

Despite the differences in the mechanisms and the kinetics of lipid oxidation in meat products, wine pomace products presented antioxidant activity in a wide range of meat products, storage conditions and processes, revealing its suitability for these sorts of products. For instance, grape antioxidant dietary fiber presented interesting antioxidant activity in muscle samples stored at room temperature (Yu et al., 2013), under refrigeration (Ahn et al., 2004; Sáyago-Ayerdi et al., 2009) or under frozen conditions (Brannan \& Mah, 2007; Colindres \& Susan Brewer, 2011; Kulkarni et al., 2011; Sánchez-Alonso et al., 2006). Other grape antioxidant products also showed successful results in raw and cooked products (Colindres \& Susan Brewer, 2011; 
Nissen et al., 2004; Selani et al., 2011). Furthermore, the antioxidant activity of different products derived from wine pomace has been described in samples packaged in air (Gómez et al., 2014; Price et al., 2013), under vacuum packaging (Rojas \& Brewer, 2008; Sánchez-Alonso et al., 2008), and under modified atmosphere packaging (Garrido et al., 2011; Jongberg et al., 2011).

Apart from the protection exerted during meat storage, wine pomace products may also limit the lipid oxidation produced in different treatments such as high pressure process (Montero et al., 2005), electron beam radiation (Rababah et al., 2006), gamma irradiation (Schevey et al., 2013), extrusion (Camire \& Dougherty, 1998), restructuration (Reddy et al., 2013), microwave exposure (Rababah et al., 2012a), salting (Brannan, 2008; Lau \& King, 2003), dehydration (Nissen et al., 2000), freezethaw cycles (Nirmal \& Benjakul, 2010) and curing (Lorenzo et al., 2013; Wang et al., 2015b; Wójciak et al., 2011).

Apart from meat products, wine pomace products were effective at inhibiting lipid oxidation in different fish species including: horse mackerel (Sánchez-Alonso et al., 2006), rainbow trout (Gai et al., 2015), silver carp fillets (Hasani \& Alizadeh, 2015; Shi et al., 2014), chub mackerel (Özalp Özen et al., 2011), bonito fillets (Yerlikaya \& Gokoglu, 2010), and cod (Sánchez-Alonso et al., 2007a). Fish products usually present a lipid profile with high content of PUFA and high levels of pro-oxidants such as free iron, which may promote lipid oxidation.

Regarding the prevention of lipid oxidation in fats and oils, wine pomace products have been successfully incorporated in oils with different fatty acid profile: rich in linoleic acid, such as like grape seed (Jang et al., 2015), sunflower (Poiana, 2012), soybean oils (Bakota et al., 2015), and in oils rich in oleic such as olive (Bonilla et al., 1999) and canola oils (Schevey \& Brewer, 2015). Grape seed extract was also 
incorporated into solid systems like pork lard and in oil-water emulsions (Altunkaya et al., 2013), which would be highly interesting in food systems such as mayonnaise, and salad dressing (Tseng \& Zhao, 2013). Generally, wine pomace products were less effective in oil than in muscle systems. For instance, grape seed extract promoted the formation of conjugated dienes in canola oil system, while they effectively inhibited lipid oxidation in beef patties (Schevey \& Brewer, 2015). Bakota et al. (2015) found no antioxidant activity in soybean oils, which was ascribed to the poor solubility of phenolic compounds in oil systems. In contrast, Poiana (2012) observed relevant proportions of phenols that remained in the oil (between 30 and 60\%) which exerted significant antioxidant effect, and Bakota et al. (2015) also observed lipid protection in oil-in-water emulsions. Different factors can contribute to explain the contradictory data; those factors with the highest relevance probably being the polarity of the treated samples and of the products that are used.

Wine pomace also successfully inhibited lipid oxidation in dairy products such as yoghurts (Ersöz et al., 2011; Tseng \& Zhao, 2013), cheese (Shan et al., 2011), and in vegetables-derived products such as corn (Rababah et al., 2011b) and potato chips (Rababah et al., 2012b).

\subsubsection{Protein oxidation protection}

Protein oxidation involves the formation of aminoacids derivatives, increase of carbonyl derivatives, loss of thiol groups, changes in protein structure, protein denaturation and polymerization (Lund et al., 2011). Therefore, the technological quality of proteins is reduced and solubility decreases, as well as the gelation and water-holding capacities, enzymes are deactivated and drip loss increases. Furthermore, protein oxidation presents several implications for human health such as reduced digestibility, loss of essential aminoacids and increased cytotoxicity. Protein oxidation, 
at an advanced stage, can also affect sensory quality including loss of tenderness and formation of dark pigments. (Lund et al., 2011; Soladoye et al., 2015)

Generally, the efficacy of wine pomace products at inhibiting protein oxidation is lower than against lipid oxidation. Several studies observed no protection in solubility loss (Brannan, 2008; Yu et al., 2013) and Sánchez-Alonso et al. (2007b) noted no effect against myosin loss. White wine pomace extract promoted the loss of thiol groups, but inhibited carbonyl formation and myosin cross-link formation, suggesting that grape phenols may interact with thiols avoiding protein aggregation (Jongberg et al., 2011). Grape seed polyphenols were also effective inhibiting carbonyl formation and protecting thiol groups (Yu et al., 2013).

\subsection{Interaction with microorganims in food}

Wine pomace presents different constituents such as fiber, acids, salts and phenolic compounds that can interact with food microorganisms, mainly due to their positive or negative capacity to influence the growth of microorganims. Generally, antimicrobial activity is the most extensively studied, and among wine pomace components, phenolic compounds are the most widely studied agents, due to their wellknown anti-bacterial and anti-mold activity.

\subsubsection{Antimicrobial action against food spoilage microorganisms}

Spoilage flora includes those microorganisms that deteriorate food quality reducing consumer acceptance of the final product and limiting their shelf-life without pathogenic effects (Gill et al., 1996). Deterioration caused by spoilage flora is usually associated with the formation of volatiles that cause off-flavors, color deterioration, acidification, slime formation and gas formation. 


\section{CHAPTER 1}

The most relevant conditions that may affect the development of spoilage flora in foods are the initial microbial population, food processing contaminations and storage conditions (temperature, packaging) (Gill et al., 1996). In air-packaged atmospheres, Pseudomonas is usually the predominant population causing putrid and sulfur odors, due to the formation of ethyl esters and sulfur compounds. Pseudomonas growth may be inhibited by using $\mathrm{CO}_{2}$ in the atmosphere packaging or by using vacuum packaging. In these cases, lactic acid bacteria (which are facultative anaerobic and present a high tolerance to $\mathrm{CO}_{2}$ ) become the predominant microbial group (Schillinger et al., 2006). The genera most frequently involved in food spoilage are Lactobacillus, Pediococcus, Streptococcus and Leuconostoc. Enterobacteriaceae are also very resistant to $\mathrm{CO}_{2}$ and anaerobic conditions and are responsible for putrefactive deteriorations, shortening the shelf-life of food products. Other microorganisms involved in food spoilage include Brochothrix thermosphacta, Aeromonas spp and Alteromonas putregaciens (Borch et al., 1996).

Due to the problems caused by spoilage flora, the food industry is constantly looking for new strategies to inhibit their growth. Over recent years, the strategies have been focused on new natural compounds with antimicrobial activity to replace the use of chemical preservatives. Different products obtained from wine pomace, especially grape seed extracts, have been proposed to control spoilage growth. The growth of total aerobic mesophilic bacteria (TAMB), lactic acid bacteria (LAB), Pseudomonas and psychrotropic populations of pork patties were delayed by the incorporation of seed extracts (Lorenzo et al., 2014). In comparison to other natural extracts such as tea, seaweed and chestnut extracts, higher antimicrobial action was exerted by grape seed extract. In addition, Bañón et al. (2007) also described delaying activity against TAMB and total coliform count, and an effect against Pseudomonas was also described by 
Király-Véghely et al. (2009). Sagdic et al. (2011) studied the effect of five grape pomace extracts at different concentrations between 1 and $10 \%$ and noted bactericidal effects against the populations of TAMB, psychrotrophic, lipolytic and proteolytic bacteria, yeast and molds, micrococcaceae, lactobacilli and lactococci after 2 hours of applications. Wine pomace showed antimicrobial activity against spoilage population such as TAMB and psychrotropic hydrogen sulfide-producing populations (Ribeiro et al., 2013). Similar results have recently been pointed out by Hasani \& Alizadeh, (2015), however, in this case, the effect was less relevant than in other studies. Other researches showed that low concentrations of grape extracts (lower than $0.2 \%$ ) had no effect on the final population or only produced slight lower final counts of TAMB (Garrido et al., 2011; Kumar et al., 2015). The lack of any antimicrobial effect was ascribed to the low level applied and to matrix-phenol interactions that may limit the antimicrobial capacity of phenolic compounds. Wine pomace products may also exert an inhibitory effect against yeasts and molds, (Corrales et al., 2010; Yadav et al., 2015) and grape pomace showed antimicrobial activity against spoilage population (Ribeiro et al., 2013).

Apart from the capacity of wine products to limit microbial growth they may be able to induce metabolic changes and to mitigate some of the deteriorative reactions and effect caused by spoilage metabolism, such as gas formation (Jun Yamakoshi, 2001), slime formation (Furiga et al., 2014), acid production (Thimothe et al., 2007) and the formation of biogenic amines (Alberto et al., 2007; Wang et al., 2015a).

\subsubsection{Antimicrobial action against foodborne pathogens}

The consumption of food contaminated with foodborne pathogens causes more than 320,000 outbreaks each year in the European Union, being eggs, meat and fish products those provoking the highest number of cases (EFSA \& ECDC, 2015). 


\section{CHAPTER 1}

A large number of studies have been published describing the in vitro effect of wine pomace products against foodborne pathogens, while the evaluation in food matrix is more limited. The published results show that the efficacy against pathogens depends on the product concentration, the microorganism under study (even at strain level), and the $\mathrm{pH}$ and polarity of the matrix (Al-Habib et al., 2010; Rhodes et al., 2006; Vaquero et al., 2007).

Grape seed extracts (at 1\%) presented bactericidal effect against Escherichia coli and Salmonella typhimurium, and delayed the growth of Listeria monocytogenes and Aeromonas hydrophila (Ahn et al., 2007), but when incorporated into films they only presented slight activity against Brochothrix thermosphacta (Corrales et al., 2009). They were also effective in cheese inoculated with L. monocytogenes, Staphylococcus aureus, and Salmonella enterica (Shan et al., 2011). The concentrations required to observe the antimicrobial effect were higher than in vitro assays, which suggested a decrease in the antimicrobial effect when the products were added to foods. Probably, the low solubility in certain foods and the interaction of polyphenols with other food components can explain the lower effect (Corrales et al., 2009; Shelef, 1984). Red grape pomace extract and powder also presented activity against E. coli and S. aureus at concentrations ranging between 2 and 10\% (Sagdic et al., 2012b), and wine pomace extracts were shown to inhibit the formation of microbial films (Xu et al., 2014).

It has been noted in the literature that grape seed extracts exhibit higher inhibition than the corresponding skin extracts (Rhodes et al., 2006; Xu et al., 2014). In the case of non-extracted products, grape pomace also presented activity against S.aureus and E.coli (Sagdic et al., 2012b). In contrast, Kim et al. (2012) reported that wine pomace only presented antimicrobial effects after being fermented by Lactobacillus casei. 
Generally, gram positive bacteria exhibit higher sensitivities towards wine pomace products than gram negative bacteria (Corrales et al., 2009; Delgado Adámez et al., 2012; Xu et al., 2014), although contradictory results have also been reported (Cueva et al., 2012; Katalinić et al., 2010). These different sensitivities could be explained by the presence of the lipopolysaccharide cell wall in gram-negative, which can limit the penetration of phenolic into the cell. Furthermore, the presence of efflux pumps in some gram-negative bacteria like E. coli could contribute to their higher resistance (Xu et al., 2014). Moreover, some gram negative bacteria are able to metabolize certain phenolic compounds such as hydroxycinnamic acids, deactivating their antimicrobial effect (Vaquero et al., 2007).

The antimicrobial effect of wine pomace products is usually ascribed to different phenolic compounds. Several studies have shown the predominant role of phenolic acids (mainly gallic acid followed by p-hydroxybenzoic and vanillic acids) in comparison to flavonoids. In this sense, gallic acid was found to be the strongest antimicrobial agents of grape seeds extracts (Tesaki et al., 1999). Corrales et al. (2009) suggested the higher potential of hydroxycinnamic acids in comparison to their corresponding hydroxybenzoic acids, due to their lower polarity that means they can cross through the cell membrane. Mingo et al. (2016) pointed to epicatechin gallate and resveratrol as the most active compounds against Campylobacter. In contrast, polymeric compounds seems to be more active than the corresponding monomeric compounds in grape seed and skin extracts (Rhodes et al., 2006).

It is interesting to point out that generally pure compounds present a much lower activity than the wine pomace products, which reveals a synergistic effect of all the phenolic compounds (Silván et al., 2013; Xu et al., 2014). For example, a fractionated extract rich in caftaric acid presented a high antimicrobial effect against 
Campylobacter jejuni, while pure caftaric acid was not active itself (Silván et al., 2013). Pure phenolic compounds including gallic acid, caffeic acid, catechin, ellagic acid and quercetin presented little or no effect against S. aureus, S. enterica and E. coli in comparison to grape seed and skin extracts (Xu et al., 2014). Rodríguez Vaquero et al. (2010) observed that combinations of flavonoids and phenolic acids produced a synergistic effect against $E$. coli that was corroborated in a meat system. The combinations showed bactericidal effect in contrast to individual phenolic compounds with only bacteriostatic activity. Consequently, it appears that a combination of different compounds is more effective than the use of pure compounds.

Different mechanisms have been suggested to explain the antimicrobial effect observed for wine pomace products. Partially hydrophobic phenols are able to penetrate in the phospholipid bilayer and induce several changes in cell functions including membrane disruption and structural changes (Cowan, 1999). The presence of an outer membrane of hydrophilic nature in the gram-negative bacteria seems to prevent polyphenols from entering the cytoplasmatic membrane. Modified structures of $S$. aureus producing larger, rougher and irregular cells were observed after being incubated with grape seed extracts (Al-Habib et al., 2010). Wine pomace products may also be able to enter the cell and deactivate intracellular material such as enzymes (Thimothe et al., 2007) or intercalate into the microbial DNA (Sivarooban et al., 2008). Another potential mechanism of phenolic compounds, especially high-molecular weight compounds are metal chelation (Chung et al., 1998) and protein precipitation (Shibambo, 2008), limiting the transference of these nutrients into the cell. Furthermore, phenolic compounds may inactivate extracellular microbial enzymes limiting microbial growth (Scalbert, 1991). 


\subsubsection{Protection of probiotics}

In contrast with the more widely studied effect of growth inhibition of spoilage and foodborne pathogenic flora, some published studies also showed the capacity of wine pomace products to promote the activity or to protect probiotic microorganisms against different altering external factors.

The effect of phenolic compounds on the growth of lactic acid bacteria may vary widely according to the chemical structure and the concentration of each phenolic compound. It also depends on microorganism, strain, media growth and the growth phase (H. Rodríguez et al., 2009). Wine pomace and grape seed extracts were able to promote L. acidophilus (Hervert-Hernández et al., 2009). The authors highlighted that as LAB do not require heme enzymes in their metabolism, the chelating activity of phenolic compounds would not affect LAB growth. Growth of L. hilgardii was also enhanced by the presence of catechin and gallic acid (Alberto et al., 2001). These effects were ascribed to their ability to metabolize these phenolic compounds, and to enhance sugar metabolism.

Regarding food applications, grape pomace enhanced L. acidophilus fermentation, stimulating lactic acid production reduced the fermentation time (Frumento et al., 2013). A similar effect was observed by Aliakbarian et al. (2015) who reported higher counts of $S$. thermophilus and L. acidophilus after fermentation. Pomace flour had no effect on the fermentation time, but enhanced probiotic resistance to simulated gastrointestinal conditions (Casarotti \& Penna, 2015), and grape seed extract may protect probiotic LAB against cell injury caused by freezing and prevent the decay of bacterial counts (Sagdic et al., 2012a). 


\section{CHAPTER 1}

\subsection{Effect on neo-formed contaminants}

Industrial and household heat treatments are required in order to develop an acceptable taste, increase digestibility and assure the safety of some food products. However, processes at high temperature also involve the formation of the so-called neo-formed contaminants (NFCs) with toxicological effects (Birlouez-Aragon et al., 2010). Many of these compounds are related to Maillard reactions, which involve a condensation reaction between free amino groups and carbonyl compounds (from reducing sugars, aldehydes or ketones). Generally, anti-Maillard activity has been ascribed to polyphenols, which seems to be due to polyphenol-amine and polyphenolsugar interactions (Ortega-Heras \& González-Sanjosé, 2009; Totlani \& Peterson, 2005) and their radical-scavenging activity (Sylwia Mildner-Szkudlarz et al., 2015). Products derived from wine have shown inhibition against the formation of different NFCs: heterocyclic amines (HAAs), polycyclic aromatic hydrocarbons (PAHs), acrylamide, advanced glycation end products (AGEs) and furans.

Generally, HAs are compounds with three fused aromatic rings and at least one nitrogen atom in the ring as well as one exocyclic amino group. Different types of HAs may be formed depending on the cooking temperature (thermic and pyrolitic HAs). Thermic HAs are formed through reaction of creatine and reducing sugars as part of Maillard reaction, whereas pyrolitic HAs are formed through pyrolityc reactions (preferably formed at temperatures above $250^{\circ} \mathrm{C}$ ). One thermic HA (2-Amino-3methylimidazo[4,5-f]quinolone, IQ) has been listed as "probable human carcinogen" (Group 2A), three thermic and 6 pyrolitic are listed in the group 2B as possible human carcinogens according to International Agency for Research on Cancer (IARC, 1986, 1993). 
Different studies have shown the high effectiveness of grape seed extract at limiting the formation of HAs and proanthocyanindins are of high relevance in the inhibitory effect (Cheng et al., 2007; Rounds et al., 2012). Marinating with red and white wine also mitigated the formation of HAs in pan-fried beef (Melo et al., 2008; Viegas et al., 2012). The activity was ascribed to the ability of phenols to scavenge radicals from the Strecker degradation and highlighted that other components, such as hexose and pentose, can also contribute to the observed inhibition (Gibis \& Weiss, 2012). However, other studies show only low protection against nonpolar HAs and even some promoting effect (Busquets et al., 2006; Gibis \& Weiss, 2012), ascribed to the presence of metals.

PAHs may also be formed in relevant amounts during the heat treatment of meat and meat products. Substances rich in antioxidants have been suggested to inhibit their formation (Janoszka, 2011; Viegas et al., 2014) and the effect was positively correlated to the radical scavenging activity of the product that was used (Viegas et al., 2014). However, the literature is still scarce and no studies regarding the activity of wine pomace products have been conducted in food.

Acrylamide is also classified as a "probably carcinogenic" agent (2A) found in starchy food cooked at high temperatures such as potatoes and cereal products (IARC, 1994). Grape seed proanthocyanidins inhibited the formation of acrylamide in starchbased models (Zhu et al., 2011) and wine pomace skin and seed extracts mitigated the formation of acrylamide in model systems and during the frying of potato chips (Xu et al., 2015). Skin extracts presented higher activity than seeds extracts, and the authors related this effect to a possible combination between polyphenols and Maillard products blocking the formation of acrylamide. 
During heat treatments, advanced glycation end products (AGEs) were also formed, Ne-carboxymethyl-lysine (CML) being the most abundant in food due to the reaction between lysine and carbonyl groups of reducing sugars and of lipid oxidation products (Goldberg et al., 2004). It was reported that AGEs derived from diet are absorbed and accumulated in human tissue, increasing the risk of diabetic and cardiovascular complications and renal diseases (Nguyen et al., 2014). Grape polyphenols have reported inhibitory activity against the formation of CML in muffins. The effect was dependent on the formulation, with the lowest effect in those formulations rich in protein (Sylwia Mildner-Szkudlarz et al., 2015). The results were ascribed to their scavenging of free-radicals as well as their ability to trap intermediate compounds with carbonyl groups. The formation of fructosamine, another AGE, was also inhibited by a red skin wine pomace extract (Jariyapamornkoon et al., 2013).

Plant polyphenols were also able to limit the formation of furans (including furfural and hydroxymethylfurfural) in a glycine-glucose model system (Oral et al., 2014), probably due to the capacity of phenolic compounds to interact and to block the Maillard reaction.

\subsection{Other properties and further applications}

\subsubsection{Anti-polyphenol oxidase activity}

Polyphenol oxidase (PPO) is a copper-containing enzyme distributed in different food products that catalyzes the oxidation of o-diphenols to o-quinones. Oquinones can undergo polymerization and form brown pigments, limiting the shelf life of some products. Melanosis is one of the main problems related to PPO within the food industry, due its high impact on the visual appearance of the product. Melanosis of shrimp was inhibited by immersion in solutions of 2.5-15 g/l of grape seed extract (Gokoglu \& Yerlikaya, 2008; Sun et al., 2014). Other products rich in antioxidants 
were used in dipping solutions to inhibit polyphenol oxidase in other matrices such as fruits (Soysal, 2009). The protective activity against PPO may be ascribed to the high capacity to reduce the o-quinones formed by the action of PPO, forming colorless odiphenol. Furthermore, wine pomace products were also suggested to inhibit the activity by chelating copper, scavenging free radicals or directly inactivating the enzyme (Nirmal \& Benjakul, 2011).

\subsubsection{Reduction of residual nitrites and Nitrosamines}

Nitrates and nitrites are added to food, especially to meat products, due to their reaction with myoglobin producing the typical color of cured products. Furthermore, nitrites and nitrates present antioxidant and antimicrobial activity that inhibit the growth of Clostridium botulinum. Nitrite consumption, per se, can be toxic producing methemoglobinemia and lowering blood pressure (Lundberg et al., 2008). Furthermore, the nitrite that does not react with myoglobin, can react with other free amines to rend nitrosamines that are considered potential carcinogens (IARC, 1978).

Grape seed extract was able to reduce the residual levels of nitrite after ripening of dry-cured sausages and to decrease the formation of nitrosamines ( $\mathrm{Li}$ et al., 2013), and to inhibit N-nitrosodimethylamine (NDMA) formation (Wang et al., 2015a). It seems that polyphenols may remove residual nitrite by reduction or by direct reaction (Fernández-López et al., 2007; Viuda-Martos et al., 2009). Polyphenols may also mitigate the formation of nitrosamines by inhibiting microbial activity and by scavenging the radicals involved in amine formation (Dong et al., 2013).

In spite of the large amount of literature published on the existing applications of wine pomace products, the high potential of the revalorization of this by-product in the development of new successful food applications is a compelling reason for further research. 


\section{REFERENCES}

Acun, S., \& Gül, H. (2014). Effects of grape pomace and grape seed flours on cookie quality. Quality Assurance and Safety of Crops and Foods, 6(1), 81-88.

Adams, T. B., Doull, J., Feron, V. J., Goodman, J. I., Marnett, L. J., Munro, I. C., Newberne, P. M., Portoghese, P. S., Smith, R. L., Waddell, W. J., \& Wagner, B. M. (2002). The FEMA GRAS assessment of pyrazine derivatives used as flavor ingredients. Food and Chemical Toxicology, 40(4), 429-451.

Aghamirzaei, M., Peighambardoust, S. H., Azadmard-Damirchi, S., \& Majzoobi, M. (2015). Effects of grape seed powder as a functional ingredient on flour physicochemical characteristics and dough rheological properties. Journal of Agricultural Science and Technology, 17(2), 365-373.

Ahn, J., Grün, I. U., \& Fernando, L. N. (2002). Antioxidant properties of natural plant extracts containing polyphenolic compounds in cooked ground beef. Journal of Food Science, 67(4), 1364-1369.

Ahn, J., Grün, I. U., \& Mustapha, A. (2004). Antimicrobial and Antioxidant Activities of Natural Extracts in Vitro and in Ground Beef. Journal of Food Protection, 67(1), 148-155.

Ahn, J., Grün, I. U., \& Mustapha, A. (2007). Effects of plant extracts on microbial growth, color change, and lipid oxidation in cooked beef. Food Microbiology, 24(1), 7-14.

Aksoylu, Z., Çağindi, Ö., \& Köse, E. (2015). Effects of Blueberry, Grape Seed Powder and Poppy Seed Incorporation on Physicochemical and Sensory Properties of Biscuit. Journal of Food Quality, 38(3), 164-174.

Al-Habib, A., Al-Saleh, E., Safer, A. M., \& Afzal, M. (2010). Bactericidal effect of grape seed extract on methicillin-resistant Staphylococcus aureus (MRSA). Journal of Toxicological Sciences, 35(3), 357-364.

Alberto, M. R., Arena, M. E., \& Manca de Nadra, M. C. (2007). Putrescine production from agmatine by Lactobacillus hilgardii: Effect of phenolic compounds. Food Control, 18(8), 898-903.

Alberto, M. R., Farías, M. E., \& Manca de Nadra, M. C. (2001). Effect of Gallic Acid and Catechin on Lactobacillus hilgardii 5w Growth and Metabolism of Organic Compounds. Journal of Agricultural and Food Chemistry, 49(9), 4359-4363.

Alfawaz, M., Smith, J. S., \& Jeon, I. J. (1994). Maillard reaction products as antioxidants in pre-cooked ground beef. Food Chemistry, 51(3), 311-318.

Aliakbarian, B., Casale, M., Paini, M., Casazza, A. A., Lanteri, S., \& Perego, P. (2015). Production of a novel fermented milk fortified with natural antioxidants and its analysis by NIR spectroscopy. LWT - Food Science and Technology, 62(1), 376-383.

Altunkaya, A., Hedegaard, R. V., Harholt, J., Brimer, L., Gokmen, V., \& Skibsted, L. H. (2013). Oxidative stability and chemical safety of mayonnaise enriched with grape seed extract. Food \& Function, 4(11), 1647-1653. 
Amico, V., Chillemi, R., Mangiafico, S., Spatafora, C., \& Tringali, C. (2008). Polyphenol-enriched fractions from Sicilian grape pomace: HPLC-DAD analysis and antioxidant activity. Bioresource Technology, 99(13), 5960-5966.

Amico, V., Napoli, E. M., Renda, A., Ruberto, G., Spatafora, C., \& Tringali, C. (2004). Constituents of grape pomace from the Sicilian cultivar 'Nerello Mascalese'. Food Chemistry, 88(4), 599-607.

Anderson, J. W., Baird, P., Davis Jr, R. H., Ferreri, S., Knudtson, M., Koraym, A., Waters, V., \& Williams, C. L. (2009). Health benefits of dietary fiber. Nutrition Reviews, 67(4), 188-205.

Andrades Rodríguez, M. S., \& González San José, M. L. (1995). Influencia climática en la maduración de la uva: estudio de cultivares de la Rioja y de Madrid. In: Monográfico "El vino”. In, vol. 7 (pp. 79-102). Logroño, Spain: Instituto de Estudios Riojanos.

Arnous, A., \& Meyer, A. S. (2008). Comparison of methods for compositional characterization of grape (Vitis vinifera L.) and apple (Malus domestica) skins. Food and Bioproducts Processing, 86(2), 79-86.

Arvanitoyannis, I. S., Ladas, D., \& Mavromatis, A. (2006). Potential uses and applications of treated wine waste: A review. International Journal of Food Science and Technology, 41(5), 475-487.

Augustine, S., Kudachikar, V. B., Vanajakshi, V., \& Ravi, R. (2013). Effect of combined preservation techniques on the stability and microbial quality and retention of anthocyanins in grape pomace stored at low temperature. Journal of Food Science and Technology, 50(2), 332-338.

Ayed, N., Yu, H. L., \& Lacroix, M. (1999). Improvement of anthocyanin yield and shelf-life extension of grape pomace by gamma irradiation. Food Research International, 32(8), 539-543.

Bakota, E. L., Winkler-Moser, J. K., Berhow, M. A., Palmquist, D. E., \& Liu, S. X. (2015). Antioxidant Activity of Hybrid Grape Pomace Extracts Derived from Midwestern Grapes in Bulk Oil and Oil-in-Water Emulsions. JAOCS, Journal of the American Oil Chemists' Society, 92(9), 1333-1348.

Bañón, S., Díaz, P., Rodríguez, M., Garrido, M. D., \& Price, A. (2007). Ascorbate, green tea and grape seed extracts increase the shelf life of low sulphite beef patties. Meat Science, 77(4), 626-633.

Bekhit, A. E. D., Cheng, V. J., McConnell, M., Zhao, J. H., Sedcole, R., \& Harrison, R. (2011). Antioxidant activities, sensory and anti-influenza activity of grape skin tea infusion. Food Chemistry, 129(3), 837-845.

Birlouez-Aragon, I., Morales, F., Fogliano, V., \& Pain, J. P. (2010). The health and technological implications of a better control of neoformed contaminants by the food industry. Pathologie Biologie, 58(3), 232-238.

Bobek, P. (1999). Dietary tomato and grape pomace in rats: Effect on lipids in serum and liver, and on antioxidant status. British Journal of Biomedical Science, 56(2), 109-113. 
Bonilla, F., Mayen, M., Merida, J., \& Medina, M. (1999). Extraction of phenolic compounds from red grape marc for use as food lipid antioxidants. Food Chemistry, 66(2), 209-215.

Borch, E., Kant-Muermans, M.-L., \& Blixt, Y. (1996). Bacterial spoilage of meat and cured meat products. International Journal of Food Microbiology, 33(1), 103120.

Borderías, A. J., Sánchez-Alonso, I., \& Pérez-Mateos, M. (2005). New applications of fibres in foods: Addition to fishery products. Trends in Food Science \& Technology, 16(10), 458-465.

Bors, W., Heller, W., Michel, C., \& Saran, M. (1990). Flavonoids as antioxidants: Determination of radical-scavenging efficiencies. Methods in Enzymology, vol. 186 (pp. 343-355): Academic Press.

Boussetta, N., Lebovka, N., Vorobiev, E. n., Adenier, H., Bedel-Cloutour, C., \& Lanoisellé, J.-L. (2009). Electrically Assisted Extraction of Soluble Matter from Chardonnay Grape Skins for Polyphenol Recovery. Journal of Agricultural and Food Chemistry, 57(4), 1491-1497.

Brannan, R. G. (2008). Effect of Grape Seed Extract on Physicochemical Properties of Ground, Salted, Chicken Thigh Meat during Refrigerated Storage at Different Relative Humidity Levels. Journal of Food Science, 73(1), C36-C40.

Brannan, R. G., \& Mah, E. (2007). Grape seed extract inhibits lipid oxidation in muscle from different species during refrigerated and frozen storage and oxidation catalyzed by peroxynitrite and iron/ascorbate in a pyrogallol red model system. Meat Science, 77(4), 540-546.

Bravo, L., \& Saura-Calixto, F. (1998). Characterization of dietary fiber and the in vitro indigestible fraction of grape pomace. American Journal of Enology and Viticulture, 49(2), 135-141.

Brenes, A., Viveros, A., Goñi, I., Centeno, C., Sáyago-Ayerdy, S. G., Arija, I., \& Saura-Calixto, F. (2008). Effect of Grape Pomace Concentrate and Vitamin E on Digestibility of Polyphenols and Antioxidant Activity in Chickens. Poultry Science, 87(2), 307-316.

Busquets, R., Puignou, L., Galceran, M. T., \& Skog, K. (2006). Effect of Red Wine Marinades on the Formation of Heterocyclic Amines in Fried Chicken Breast. Journal of Agricultural and Food Chemistry, 54(21), 8376-8384.

Cagdas, E., \& Kumcuoglu, S. (2014). Effect of grape seed powder on oxidative stability of precooked chicken nuggets during frozen storage. Journal of Food Science and Technology, 52(5), 2918-2925.

Camire, M. E., \& Dougherty, M. P. (1998). Added phenolic compounds enhance lipid stability in extruded corn. Journal of Food Science, 63(3), 516-518.

Camo, J., Lorés, A., Djenane, D., Beltrán, J. A., \& Roncalés, P. (2011). Display life of beef packaged with an antioxidant active film as a function of the concentration of oregano extract. Meat Science, 88(1), 174-178.

Canett Romero, R., Ledesma Osuna, A. I., Robles, S., Rosario Maribel, Morales Castro, R., León Martínez, L., \& León-Gálvez, R. (2004). Caracterización de 
galletas elaboradas con cascarilla de orujo de uva. Archivos Latinoamericanos de Nutrición, 54, 93-99.

Cappa, C., Lavelli, V., \& Mariotti, M. (2015). Fruit candies enriched with grape skin powders: physicochemical properties. LWT - Food Science and Technology, 62(1, Part 2), 569-575.

Carocho, M., Morales, P., \& Ferreira, I. C. F. R. (2015). Natural food additives: Quo vadis? Trends in Food Science and Technology, 45(2), 284-295.

Carpenter, R., O'Grady, M. N., O'Callaghan, Y. C., O'Brien, N. M., \& Kerry, J. P. (2007). Evaluation of the antioxidant potential of grape seed and bearberry extracts in raw and cooked pork. Meat Science, 76(4), 604-610.

Casarotti, S. N., \& Penna, A. L. B. (2015). Acidification profile, probiotic in vitro gastrointestinal tolerance and viability in fermented milk with fruit flours. International Dairy Journal, 41, 1-6.

Coe, S., \& Ryan, L. (2016). White bread enriched with polyphenol extracts shows no effect on glycemic response or satiety, yet may increase postprandial insulin economy in healthy participants. Nutrition Research, 36(2), 193-200.

Colindres, P., \& Susan Brewer, M. (2011). Oxidative stability of cooked, frozen, reheated beef patties: Effect of antioxidants. Journal of the Science of Food and Agriculture, 91(5), 963-968.

Coombe, B. G. (1987). Distribution of Solutes within the Developing Grape Berry in Relation to Its Morphology. American Journal of Enology and Viticulture, 38(2), 120-127.

Corrales, M., Fernandez, A., Vizoso Pinto, M. G., Butz, P., Franz, C. M. A. P., Schuele, E., \& Tauscher, B. (2010). Characterization of phenolic content, in vitro biological activity, and pesticide loads of extracts from white grape skins from organic and conventional cultivars. Food and Chemical Toxicology, 48(12), 3471-3476.

Corrales, M., Han, J. H., \& Tauscher, B. (2009). Antimicrobial properties of grape seed extracts and their effectiveness after incorporation into pea starch films. International Journal of Food Science \& Technology, 44(2), 425-433.

Corrales, M., Toepfl, S., Butz, P., Knorr, D., \& Tauscher, B. (2008). Extraction of anthocyanins from grape by-products assisted by ultrasonics, high hydrostatic pressure or pulsed electric fields: A comparison. Innovative Food Science and Emerging Technologies, 9(1), 85-91.

Cowan, M. M. (1999). Plant Products as Antimicrobial Agents. Clinical Microbiology Reviews, 12(4), 564-582.

Cueva, C., Mingo, S., Muñoz-González, I., Bustos, I., Requena, T., del Campo, R., Martín-Álvarez, P. J., Bartolomé, B., \& Moreno-Arribas, M. V. (2012). Antibacterial activity of wine phenolic compounds and oenological extracts against potential respiratory pathogens. Letters in Applied Microbiology, 54(6), 557-563.

Czochanska, Z., Foo, L. Y., \& Porter, L. J. (1979). Compositional changes in lower molecular weight flavans during grape maturation. Phytochemistry, 18(11), 1819-1822. 
Chen, Y., Zheng, R., Jia, Z., \& Ju, Y. (1990). Flavonoids as superoxide scavengers and antioxidants. Free Radical Biology and Medicine, 9(1), 19-21.

Cheng, K. W., Wu, Q., Zong, P. Z., Peng, X., Simon, J. E., Chen, F., \& Wang, M. (2007). Inhibitory effect of fruit extracts on the formation of heterocyclic amines. Journal of Agricultural and Food Chemistry, 55(25), 10359-10365.

Choi, Y.-S., Choi, J.-H., Han, D.-J., Kim, H.-Y., Lee, M.-A., Kim, H.-W., Lee, J.-W., Chung, H.-J., \& Kim, C.-J. (2010). Optimization of replacing pork back fat with grape seed oil and rice bran fiber for reduced-fat meat emulsion systems. Meat Science, 84(1), 212-218.

Chouchouli, V., Kalogeropoulos, N., Konteles, S. J., Karvela, E., Makris, D. P., \& Karathanos, V. T. (2013). Fortification of yoghurts with grape (Vitis vinifera) seed extracts. LWT - Food Science and Technology, 53(2), 522-529.

Chung, K. T., Lu, Z., \& Chou, M. W. (1998). Mechanism of inhibition of tannic acid and related compounds on the growth of intestinal bacteria. Food and Chemical Toxicology, 36(12), 1053-1060.

Decker, E., \& Mei, L. (1996). Antioxidant mechanisms and applications in muscle foods. In Proceedings of the American Meat Science Association: 49th Reciprocal Meat Conference, (pp. 64). Brigham Young University, Provo, UT.

Delgado Adámez, J., Gamero Samino, E., Valdés Sánchez, E., \& González-Gómez, D. (2012). In vitro estimation of the antibacterial activity and antioxidant capacity of aqueous extracts from grape-seeds (Vitis vinifera L.). Food Control, 24(1-2), 136-141.

Di Cagno, R., Buchin, S., de Candia, S., De Angelis, M., Fox, P. F., \& Gobbetti, M. (2007). Characterization of Italian Cheeses Ripened Under Nonconventional Conditions. Journal of Dairy Science, 90(6), 2689-2704.

Dong, L., Zhu, J., Li, X., \& Li, J. (2013). Effect of tea polyphenols on the physical and chemical characteristics of dried-seasoned squid (Dosidicus gigas) during storage. Food Control, 31(2), 586-592.

Duque, A. L., Pinto, M. d. C., \& Macias, P. (2011). Lipoxygenase inhibition by red wine phenolics compounds. Journal of Food Biochemistry, 35(2), 542-555.

Dwyer, K., Hosseinian, F., \& Rod, M. (2014). The Market Potential of Grape Waste Alternatives. Journal of Food Research, 3(2), 91-106.

EFSA. (2005). Opinion of the Scientific Panel on Dietetic products, nutrition and allergies [NDA] on a request from the Commission related to the Tolerable Upper Intake Level of Potassium. The EFSA Journal, 193, 1-19.

EFSA, \& ECDC. (2015). The European Union summary report on trends and sources of zoonoses, zoonotic agents and food-borne outbreaks in 2013. EFSA Journal 2015, 13(1), 1-165.

Ersöz, E., Kinik, O., Yerlikaya, O., \& Açu, M. (2011). Effect of phenolic compounds on characteristics of strained yoghurts produced from sheep milk. African Journal of Agricultural Research, 6(23), 5351-5359.

Escribano-Bailón, M., Guerra, M. V., \& Rivas-Gonzalo, J. (1994). Procyanindin composition in skin and seed from grapes. Polyphenols Comunications, 94, 225-227. 
Felix da Silva, D., Matumoto-Pintro, P. T., Bazinet, L., Couillard, C., \& Britten, M. (2015). Effect of commercial grape extracts on the cheese-making properties of milk. Journal of Dairy Science, 98(3), 1552-1562.

Fernandes, L., Casal, S., Cruz, R., Pereira, J. A., \& Ramalhosa, E. (2013). Seed oils of ten traditional Portuguese grape varieties with interesting chemical and antioxidant properties. Food Research International, 50(1), 161-166.

Fernández-López, J., Viuda-Martos, M., Sendra, E., Sayas-Barberá, E., Navarro, C., \& Pérez-Alvarez, J. A. (2007). Orange fibre as potential functional ingredient for dry-cured sausages. European Food Research and Technology, 226(1-2), 1-6.

Flagg, E. W., Coates, R. J., \& Greenberg, R. S. (1995). Epidemiologic studies of antioxidants and cancer in humans. Journal of the American College of Nutrition, 14(5), 419-427.

FOAOSTAT. (2013). Food and Agriculture Organization of the United Nations. In). http://faostat3.fao.org/download/Q/QC/E.

Frankel, E. N. (1983). Volatile lipid oxidation products. Progress in Lipid Research, 22(1), 1-33.

Freeman, B. M., Lee, T. H., \& Turkington, C. R. (1979). Interaction of Irrigation and Pruning Level on Growth and Yield of Shiraz Vines. American Journal of Enology and Viticulture, 30(3), 218-223.

Frumento, D., Santo, A. P. E., Aliakbarian, B., Casazza, A. A., Gallo, M., Converti, A., \& Perego, P. (2013). Development of milk fermented with Lactobacillus acidophilus fortified with Vitis vinifera marc flour. Food Technology and Biotechnology, 51(3), 370-375.

Furiga, A., Roques, C., \& Badet, C. (2014). Preventive effects of an original combination of grape seed polyphenols with amine fluoride on dental biofilm formation and oxidative damage by oral bacteria. Journal of Applied Microbiology, 116(4), 761-771.

Gai, F., Ortoffi, M., Giancotti, V., Medana, C., \& Peiretti, P. G. (2015). Effect of Red Grape Pomace Extract on the Shelf Life of Refrigerated Rainbow Trout (Oncorhynchus mykiss) Minced Muscle. Journal of Aquatic Food Product Technology, 24(5), 468-480.

Galleano, M., Verstraeten, S. V., Oteiza, P. I., \& Fraga, C. G. (2010). Antioxidant actions of flavonoids: Thermodynamic and kinetic analysis. Archives of Biochemistry and Biophysics, 501(1), 23-30.

García-Lomillo, J., \& González-Sanjosé, M. L. (2013). Plant antioxidants as food additives. Food Science and Technology (London), 27(3), 14-16.

Garrido, M. D., Auqui, M., Martí, N., \& Linares, M. B. (2011). Effect of two different red grape pomace extracts obtained under different extraction systems on meat quality of pork burgers. LWT - Food Science and Technology, 44(10), 22382243.

Gazzola, D., Vincenzi, S., Gastaldon, L., Tolin, S., Pasini, G., \& Curioni, A. (2014). The proteins of the grape (Vitis vinifera L.) seed endosperm: Fractionation and identification of the major components. Food Chemistry, 155, 132-139. 
Gibis, M., \& Weiss, J. (2012). Antioxidant capacity and inhibitory effect of grape seed and rosemary extract in marinades on the formation of heterocyclic amines in fried beef patties. Food Chemistry, 134(2), 766-774.

Gill, C. O., McGinnis, J. C., Rahn, K., \& Houde, A. (1996). The hygienic condition of manufacturing beef destined for the manufacture of hamburger patties. Food Microbiology, 13(5), 391-396.

Gokoglu, N., \& Yerlikaya, P. (2008). Inhibition effects of grape seed extracts on melanosis formation in shrimp (Parapenaeus longirostris). International Journal of Food Science and Technology, 43(6), 1004-1008.

Goldberg, T., Cai, W., Peppa, M., Dardaine, V., Baliga, B. S., Uribarri, J., \& Vlassara, H. (2004). Advanced glycoxidation end products in commonly consumed foods. Journal of the American Dietetic Association, 104(8), 1287-1291.

Gómez, I., Beriain, M. J., Sarriés, M. V., Insausti, K., \& Mendizabal, J. A. (2014). Low-fat beef patties with augmented omega-3 fatty acid and CLA levels and influence of grape seed extract. Journal of Food Science, 79(11), S2368-S2376.

González-Centeno, M. R., Rosselló, C., Simal, S., Garau, M. C., López, F., \& Femenia, A. (2010). Physico-chemical properties of cell wall materials obtained from ten grape varieties and their byproducts: grape pomaces and stems. LWT - Food Science and Technology, 43(10), 1580-1586.

González-San José, M. L., Barron, L. J. R., \& Díez, C. (1990). Evolution of anthocyanins during maturation of tempranillo grape variety (Vitis vinifera) using polynomial regression models. Journal of the Science of Food and Agriculture, 51(3), 337-343.

Gonzalez-San Jose, M. L., Santa-Maria, G., \& Diez, C. (1990). Anthocyanins as parameters for differentiating wines by grape variety, wine-growing region, and wine-making methods. Journal of Food Composition and Analysis, 3(1), 54-66.

González-SanJosé, M. L., \& Diez, C. (1987). Presencia de pigmentos antociánicos en el reino vegetal con referencia especial al genero Vitis. Anales de Edafología y Agrobiología, XLVI(1-2), 157-162.

González-SanJosé, M. L., \& Diez, C. (1993). Caracterización varietal en función de la composición antociánica de la uva: análisis discriminante. Agrochimica, 37(12), 86-92.

González-SanJosé, M. L., Garrido, J. L., Diez, C., \& Santa-María, G. (1986). L'evolution des composes anthocyaniques au cours de la maturation des fruits des V. vinifera (VAR. CENCIBEL). Bulletin Liaison Groupe Polyphenols, 13, 389-393.

Gül, H., Acun, S., Şen, H., Nayir, N., \& Türk, S. (2013). Antioxidant activity, total phenolics and some chemical properties of Öküzgözü and Narince grape pomace and grape seed flour. Journal of Food, Agriculture and Environment, 11(2), 28-34.

Gülçin, I. (2010). Antioxidant properties of resveratrol: A structure-activity insight. Innovative Food Science and Emerging Technologies, 11(1), 210-218.

Guzmán Nieves, C. (2011). Proceso de obtención de un extracto de compuestos fenólicos a partir de orujo de uva tinta vitis vinifera a bajas temperaturas para 
aplicación en alimentos y bebidas destinados a consumo humano y animal. WO2011062468 A2. (PCT/MX2010/000133).

Han, J., Britten, M., St-Gelais, D., Champagne, C. P., Fustier, P., Salmieri, S., \& Lacroix, M. (2011). Polyphenolic compounds as functional ingredients in cheese. Food Chemistry, 124(4), 1589-1594.

Harborne, J. B. (1964). Biochemistry of phenolic compounds. . New York: Academic Press.

Hasani, S., \& Alizadeh, E. (2015). Antioxidant Effects of Grape Pomace on the Quality of Silver Carp (Hypophthalmichthys molitrix) Fillets During Refrigerated Storage. International Journal of Food Properties, 18(6), 1223-1230.

He, F. J., \& MacGregor, G. A. (2001). Beneficial effects of potassium. British Medical Journal, 323(7311), 497-501.

He, F. J., \& MacGregor, G. A. (2010). Reducing Population Salt Intake Worldwide: From Evidence to Implementation. Progress in Cardiovascular Diseases, 52(5), 363-382.

Hervert-Hernández, D., Pintado, C., Rotger, R., \& Goñi, I. (2009). Stimulatory role of grape pomace polyphenols on Lactobacillus acidophilus growth. International Journal of Food Microbiology, 136(1), 119-122.

Hoye, C., \& Ross, C. F. (2011). Total Phenolic Content, Consumer Acceptance, and Instrumental Analysis of Bread Made with Grape Seed Flour. Journal of Food Science, 76(7), S428-S436.

IARC. (1978). IARC monographs on the evaluation of carcinogenic risks to humans. Some N-Nitroso Compounds. 17, Sup 7.

IARC. (1986). IARC monographs on the evaluation of carcinogenic risks to humans. Some Naturally Occurring and Synthetic Food Components, Furocoumarins and Ultraviolet Radiation. 40, Sup 7.

IARC. (1993). IARC monographs on the evaluation of carcinogenic risks to humans. Some Naturally Occurring Substances: Food Items and Constituents, Heterocyclic Aromatic Amines and Mycotoxins. 56, Sup 7.

IARC. (1994). IARC monographs on the evaluation of carcinogenic risks to humans. Some Industrial Chemicals., 60, Sup 7.

Igartuburu, J. M., del Río, R. M., Massanet, G. M., Montiel, J. A., Pando, E., \& Luis, F. R. (1991a). Study of agricultural by-products. Extractability and amino acid composition of grapeseed (Vitis vinifera) proteins. Journal of the Science of Food and Agriculture, 54(3), 489-493.

Igartuburu, J. M., Del Río, R. M., Montiel, J., Pando, E., \& Luis, F. R. (1991b). Study of agricultural by-products. Extractability and amino acid composition of grape (Vitis vinifera) skin proteins from cv palomino. Journal of the Science of Food and Agriculture, 57(3), 437-440.

Jang, S., Lee, J., \& Choi, W. S. (2015). Oxidative stability of grape seed oil by addition of grape seed extract. Journal of the Korean Society of Food Science and Nutrition, 44(12), 1813-1818. 
Janoszka, B. (2011). HPLC-fluorescence analysis of polycyclic aromatic hydrocarbons (PAHs) in pork meat and its gravy fried without additives and in the presence of onion and garlic. Food Chemistry, 126(3), 1344-1353.

Jara-Palacios, M. J., Hernanz, D., Cifuentes-Gomez, T., Escudero-Gilete, M. L., Heredia, F. J., \& Spencer, J. P. E. (2015). Assessment of white grape pomace from winemaking as source of bioactive compounds, and its antiproliferative activity. Food Chemistry, 183, 78-82.

Jariyapamornkoon, N., Yibchok-anun, S., \& Adisakwattana, S. (2013). Inhibition of advanced glycation end products by red grape skin extract and its antioxidant activity. BMC Complementary and Alternative Medicine, 13.

Jongberg, S., Skov, S. H., Tørngren, M. A., Skibsted, L. H., \& Lund, M. N. (2011). Effect of white grape extract and modified atmosphere packaging on lipid and protein oxidation in chill stored beef patties. Food Chemistry, 128(2), 276-283.

Jun Yamakoshi, S. T., Mamoru Kikuchi, Yoshiro Kubota, Hiroyasu Konishi, Tomotari Mitsuoka. (2001). Effect of Proanthocyanidin-Rich Extract from Grape Seeds on Human Fecal Flora and Fecal Odor. Microbial Ecology in Health and Disease, 13(1), 25-31.

Jung, Y., Jung, S., Lee, H. J., Kang, M., Lee, S. K., Kim, Y. J., \& Jo, C. (2012). Effect of high pressure after the addition of vegetable oil on the safety and quality of beef loin. Korean Journal for Food Science of Animal Resources, 32(1), 68-76.

Kahl, R., \& Kappus, H. (1993). Toxicology of the synthetic antioxidants BHA and BHT in comparison with the natural antioxidant vitamin E. Zeitschrift für Lebensmittel-Untersuchung und-Forschung, 196(4), 329-338.

Kammerer, D., Claus, A., Carle, R., \& Schieber, A. (2004). Polyphenol screening of pomace from red and white grape varieties (Vitis vinifera L.) by HPLC-DADMS/MS. Journal of Agricultural and Food Chemistry, 52(14), 4360-4367.

Kanner, J. (1994). Oxidative processes in meat and meat products: Quality implications. Meat Science, 36(1-2), 169-189.

Kanner, J., Frankel, E., Granit, R., German, B., \& Kinsella, J. E. (1994). Natural antioxidants in grapes and wines. Journal of Agricultural and Food Chemistry, 42(1), 64-69.

Karaaslan, M., Ozden, M., Vardin, H., \& Turkoglu, H. (2011). Phenolic fortification of yogurt using grape and callus extracts. LWT - Food Science and Technology, 44(4), 1065-1072.

Karnopp, A. R., Figueroa, A. M., Los, P. R., Teles, J. C., Simões, D. R. S., Barana, A. C., Kubiaki, F. T., de Oliveira, J. G. B., \& Granato, D. (2015). Effects of wholewheat flour and bordeaux grape pomace (Vitis labrusca L.) on the sensory, physicochemical and functional properties of cookies. Food Science and Technology, 35(4), 750-756.

Karppanen, H., \& Mervaala, E. (2006). Sodium Intake and Hypertension. Progress in Cardiovascular Diseases, 49(2), 59-75.

Katalinić, V., Možina, S. S., Skroza, D., Generalić, I., Abramovič, H., Miloš, M., Ljubenkov, I., Piskernik, S., Pezo, I., Terpinc, P., \& Boban, M. (2010). Polyphenolic profile, antioxidant properties and antimicrobial activity of grape 
skin extracts of 14 Vitis vinifera varieties grown in Dalmatia (Croatia). Food Chemistry, 119(2), 715-723.

Kim, K. H., Yun, Y. S., Chun, S. Y., \& Yook, H. S. (2012). Antioxidant and antibacterial activities of grape pomace fermented by various microorganisms. Journal of the Korean Society of Food Science and Nutrition, 41(8), 1049-1056.

Király-Véghely, Z., Móricz, Á. M., Ott, P. G., Kátay, G., Bélai, I., \& Tyihák, E. (2009). Comparison of Components from Red and White Wines for Antimicrobial Activity by Biodetection after OPLC Separation. Journal of Liquid Chromatography \& Related Technologies, 32(9), 1259-1272.

Kliewer, W. M. (1977). Influence of Temperature, Solar Radiation and Nitrogen on Coloration and Composition of Emperor Grapes. American Journal of Enology and Viticulture, 28(2), 96-103.

Krishnaswamy, K., Orsat, V., Gariépy, Y., \& Thangavel, K. (2013). Optimization of Microwave-Assisted Extraction of Phenolic Antioxidants from Grape Seeds (Vitis vinifera). Food and Bioprocess Technology, 6(2), 441-455.

Ku, C. S., \& Mun, S. P. (2008). Antioxidant activities of ethanol extracts from seeds in fresh Bokbunja (Rubus coreanus Miq.) and wine processing waste. Bioresource Technology, 99(10), 4503-4509.

Kulkarni, S., DeSantos, F. A., Kattamuri, S., Rossi, S. J., \& Brewer, M. S. (2011). Effect of grape seed extract on oxidative, color and sensory stability of a precooked, frozen, re-heated beef sausage model system. Meat Science, 88(1), 139144.

Kumar, V., Chatli, M. K., Wagh, R. V., Mehta, N., \& Kumar, P. (2015). Effect of the combination of natural antioxidants and packaging methods on quality of pork patties during storage. Journal of Food Science and Technology, 52(10), 62306241.

Lachman, J., Hejtmánková, A., Hejtmánková, K., Horníčková, Š., Pivec, V., Skala, O., Dědina, M., \& Přibyl, J. (2013). Towards complex utilisation of winemaking residues: Characterisation of grape seeds by total phenols, tocols and essential elements content as a by-product of winemaking. Industrial Crops and Products, 49(0), 445-453.

Ladikos, D., \& Lougovois, V. (1990). Lipid oxidation in muscle foods: A review. Food Chemistry, 35(4), 295-314.

Larrauri, J. A., Rupérez, P., \& Saura-Calixto, F. (1997). Effect of Drying Temperature on the Stability of Polyphenols and Antioxidant Activity of Red Grape Pomace Peels. Journal of Agricultural and Food Chemistry, 45(4), 1390-1393.

Lau, D. W., \& King, A. J. (2003). Pre- and post-mortem use of grape seed extract in dark poultry meat to inhibit development of thiobarbituric acid reactive substances. Journal of Agricultural and Food Chemistry, 51(6), 1602-1607.

Laufenberg, G., Kunz, B., \& Nystroem, M. (2003). Transformation of vegetable waste into value added products: (A) the upgrading concept; (B) practical implementations. Bioresource Technology, 87(2), 167-198. 
Lavelli, V., Sri Harsha, P. S. C., Torri, L., \& Zeppa, G. (2014). Use of winemaking byproducts as an ingredient for tomato puree: The effect of particle size on product quality. Food Chemistry, 152, 162-168.

Lee, C. Y., \& Jaworski, A. (1987). Phenolic Compounds in White Grapes Grown in New York. American Journal of Enology and Viticulture, 38(4), 277-281.

Li, L., Shao, J., Zhu, X., Zhou, G., \& Xu, X. (2013). Effect of plant polyphenols and ascorbic acid on lipid oxidation, residual nitrite and $\mathrm{N}$-nitrosamines formation in dry-cured sausage. International Journal of Food Science and Technology, 48(6), 1157-1164.

Liu, F., Xu, Q., Dai, R., \& Ni, Y. (2015). Effects of natural antioxidants on colour stability, lipid oxidation and metmyoglobin reducing activity in raw beef patties. Acta Scientiarum Polonorum, Technologia Alimentaria, 14(1), 37-44.

Lorenzo, J. M., González-Rodríguez, R. M., Sánchez, M., Amado, I. R., \& Franco, D. (2013). Effects of natural (grape seed and chestnut extract) and synthetic antioxidants (buthylatedhydroxytoluene, BHT) on the physical, chemical, microbiological and sensory characteristics of dry cured sausage "chorizo". Food Research International, 54(1), 611-620.

Lorenzo, J. M., Sineiro, J., Amado, I. R., \& Franco, D. (2014). Influence of natural extracts on the shelf life of modified atmosphere-packaged pork patties. Meat Science, 96(1), 526-534.

Lund, M. N., Heinonen, M., Baron, C. P., \& Estévez, M. (2011). Protein oxidation in muscle foods: A review. Molecular Nutrition \& Food Research, 55(1), 83-95.

Lundberg, J. O., Weitzberg, E., \& Gladwin, M. T. (2008). The nitrate-nitrite-nitric oxide pathway in physiology and therapeutics. Nature Reviews Drug Discovery, $7(2), 156-167$.

Maestre, R., Micol, V., Funes, L., \& Medina, I. (2010). Incorporation and Interaction of Grape Seed Extract in Membranes and Relation with Efficacy in Muscle Foods. Journal of Agricultural and Food Chemistry, 58(14), 8365-8374.

Marchiani, R., Bertolino, M., Belviso, S., Giordano, M., Ghirardello, D., Torri, L., Piochi, M., \& Zeppa, G. (2016). Yogurt Enrichment with Grape Pomace: Effect of Grape Cultivar on Physicochemical, Microbiological and Sensory Properties. Journal of Food Quality, 39, 77-89.

Marchiani, R., Bertolino, M., Ghirardello, D., McSweeney, P. L. H., \& Zeppa, G. (2015). Physicochemical and nutritional qualities of grape pomace powderfortified semi-hard cheeses. Journal of Food Science and Technology, 1-12.

Marinelli, V., Padalino, L., Nardiello, D., Del Nobile, M. A., \& Conte, A. (2015). New Approach to Enrich Pasta with Polyphenols from Grape Marc. Journal of Chemistry, 2015.

Marlett, J. A., McBurney, M. I., \& Slavin, J. L. (2002). Position of the American Dietetic Association: Health implications of dietary fiber. Journal of the American Dietetic Association, 102(7), 993-1000.

Martin-Carron, N., Garcia-Alonso, A., Goñi, I., \& Saura-Calixto, F. (1997). Nutritional and physiological properties of grape pomace as a potential food ingredient. American Journal of Enology and Viticulture, 48(3), 328-332. 
Matthäus, B. (2008). Virgin grape seed oil: Is it really a nutritional highlight? European Journal of Lipid Science and Technology, 110(7), 645-650.

McGuigan, P. (2015). The less, the more? In Good Cheese, (pp. 29-30). United Kingdom: Great Taste Publications.

Melo, A., Viegas, O., Petisca, C., Pinho, O., \& Ferreira, I. M. P. L. V. (2008). Effect of beer/red wine marinades on the formation of heterocyclic aromatic amines in pan-fried beef. Journal of Agricultural and Food Chemistry, 56(22), 1062510632.

Mendes, A. C. G., Rettore, D. M., Ramos, A. L. S., da Cunha, S. F. V., de Oliveira, L. C., \& Ramos, E. M. (2014). Milano type salami elaborated with fibers of red wine byproducts. Ciencia Rural, 44(7), 1291-1296.

Menezes Oliveira, D., Rodrigues Marques, D., Kwiatkowski, A., Giriboni Monteiro, A. R., \& Clemente, E. (2013). Sensory analysis and chemical characterization of cereal enriched with grape peel and seed flour. Acta Scientiarum. Technology, 35(3), 427-431.

Meral, R., \& Doğan, I. S. (2013). Grape seed as a functional food ingredient in breadmaking. International Journal of Food Sciences and Nutrition, 64(3), 372-379.

Meyer, A. S., Jepsen, S. M., \& Sørensen, N. S. (1998). Enzymatic Release of Antioxidants for Human Low-Density Lipoprotein from Grape Pomace. Journal of Agricultural and Food Chemistry, 46(7), X-2446.

Mielnik, M. B., Olsen, E., Vogt, G., Adeline, D., \& Skrede, G. (2006). Grape seed extract as antioxidant in cooked, cold stored turkey meat. LWT - Food Science and Technology, 39(3), 191-198.

Mieres Pitre, A. (2011). Desarrollo de una galleta a partir del orujo de uva variedad criolla negra: Universidad Metropolitana.

Mildner-Szkudlarz, S., \& Bajerska, J. (2013). Protective effect of grape by-productfortified breads against cholesterol/cholic acid diet-induced hypercholesterolaemia in rats. Journal of the Science of Food and Agriculture, 93(13), 3271-3278.

Mildner-Szkudlarz, S., Bajerska, J., Zawirska-Wojtasiak, R., \& Górecka, D. (2013). White grape pomace as a source of dietary fibre and polyphenols and its effect on physical and nutraceutical characteristics of wheat biscuits. Journal of the Science of Food and Agriculture, 93(2), 389-395.

Mildner-Szkudlarz, S., Siger, A., Szwengiel, A., \& Bajerska, J. (2015). Natural compounds from grape by-products enhance nutritive value and reduce formation of CML in model muffins. Food Chemistry, 172, 78-85.

Mildner-Szkudlarz, S., Zawirska-Wojtasiak, R., Szwengiel, A., \& Pacyński, M. (2011). Use of grape by-product as a source of dietary fibre and phenolic compounds in sourdough mixed rye bread. International Journal of Food Science and Technology, 46(7), 1485-1493.

Mingo, E., Silván, J. M., \& Martinez-Rodriguez, A. J. (2016). Selective antibacterial effect on Campylobacter of a winemaking waste extract (WWE) as a source of active phenolic compounds. LWT - Food Science and Technology, 68, 418-424. 
Mironeasa, S., Codină, G. G., \& Mironeasa, C. (2012). The effects of wheat flour substitution with grape seed flour on the rheological parameters of the dough assessed by mixolab. Journal of Texture Studies, 43(1), 40-48.

Mironeasa, S., Codinə, G. G., \& Mironeasa, C. (2016). Optimization of wheat-grape seed composite flour to improve alpha-amylase activity and dough rheological behavior. International Journal of Food Properties, 19(4), 859-872.

Montero, P., Giménez, B., Pérez-Mateos, M., \& Gómez-Guillén, M. C. (2005). Oxidation stability of muscle with quercetin and rosemary during thermal and high-pressure gelation. Food Chemistry, 93(1), 17-23.

Moradi, M., Tajik, H., Razavi Rohani, S. M., \& Oromiehie, A. R. (2011). Effectiveness of Zataria multiflora Boiss essential oil and grape seed extract impregnated chitosan film on ready-to-eat mortadella-type sausages during refrigerated storage. Journal of the Science of Food and Agriculture, 91(15), 2850-2857.

Morley, W. (2013). The challenges for natural ingredients in foods - Fat, salt, sugar and air! Food Science and Technology (London), 27(1), 17-20.

Munteanu, M. F., Gligor, R., Alexa, E., Poiana, A. M., \& Onet, M. (2013). Determination of the nutritional properties from grape seed flour. Current Opinion in Biotechnology, 24, S115.

Nguyen, H. T., van der Fels-Klerx, H. J., \& van Boekel, M. A. J. S. (2014). N €(carboxymethyl)lysine: A Review on Analytical Methods, Formation, and Occurrence in Processed Food, and Health Impact. Food Reviews International, 30(1), 36-52.

Nirmal, N. P., \& Benjakul, S. (2010). Effect of catechin and ferulic acid on melanosis and quality of Pacific white shrimp subjected to prior freeze-thawing during refrigerated storage. Food Control, 21(9), 1263-1271.

Nirmal, N. P., \& Benjakul, S. (2011). Use of tea extracts for inhibition of polyphenoloxidase and retardation of quality loss of Pacific white shrimp during iced storage. LWT - Food Science and Technology, 44(4), 924-932.

Nissen, L. R., Byrne, D. V., Bertelsen, G., \& Skibsted, L. H. (2004). The antioxidative activity of plant extracts in cooked pork patties as evaluated by descriptive sensory profiling and chemical analysis. Meat Science, 68(3), 485-495.

Nissen, L. R., Månsson, L., Bertelsen, G., Huynh-Ba, T., \& Skibsted, L. H. (2000). Protection of dehydrated chicken meat by natural antioxidants as evaluated by electron spin resonance spectrometry. Journal of Agricultural and Food Chemistry, 48(11), 5548-5556.

Oral, R. A., Dogan, M., \& Sarioglu, K. (2014). Effects of certain polyphenols and extracts on furans and acrylamide formation in model system, and total furans during storage. Food Chemistry, 142, 423-429.

Ortega-Heras, M., \& González-Sanjosé, M. L. (2009). Binding capacity of brown pigments present in special Spanish sweet wines. LWT - Food Science and Technology, 42(10), 1729-1737.

Ortega-Heras, M., González-Sanjosé, M. L., \& Beltrán, S. (1999). Metal content of Spanish red wines from certified denomination of origin. Quimica Analitica, 18, 127-131. 
Özalp Özen, B., Eren, M., Pala, A., Özmen, I., \& Soyer, A. (2011). Effect of plant extracts on lipid oxidation during frozen storage of minced fish muscle. International Journal of Food Science and Technology, 46(4), 724-731.

Özlem, T., Barry, G. S., \& Gustavo, V. C. (2014). Phytochemical Quality, Microbial Stability, and Bioactive Profiles of Berry-Type Fruits, Grape, and Grape ByProducts with High-Pressure Processing. Improving Food Quality with Novel Food Processing Technologies, (pp. 215-250): CRC Press.

Özvural, E. B., \& Vural, H. (2011). Grape seed flour is a viable ingredient to improve the nutritional profile and reduce lipid oxidation of frankfurters. Meat Science, 88(1), 179-183.

Özvural, E. B., \& Vural, H. (2014). Which is the best grape seed additive for frankfurters: Extract, oil or flour? Journal of the Science of Food and Agriculture, 94(4), 792-797.

Pateiro, M., Lorenzo, J. M., Amado, I. R., \& Franco, D. (2014). Effect of addition of green tea, chestnut and grape extract on the shelf-life of pig liver pâté. Food Chemistry, 147, 386-394.

Pazos, M., González, M., Gallardo, J., Torres, J., \& Medina, I. (2005). Preservation of the endogenous antioxidant system of fish muscle by grape polyphenols during frozen storage. European Food Research and Technology, 220(5-6), 514-519.

Pedroza, M. A., Carmona, M., Pardo, F., Salinas, M. R., \& Zalacain, A. (2012). Waste grape skins thermal dehydration: potential release of colour, phenolic and aroma compounds into wine. CyTA - Journal of Food, 10(3), 225-234.

Peralbo-Molina, T., \& Luque deCastro, M. D. (2013). Potential of residues from the Mediterranean agriculture and agrifood industry. Trends in Food Science and Technology, 32(1), 16-24.

Pérez-Jiménez, J., Arranz, S., \& Saura-Calixto, F. (2009). Proanthocyanidin content in foods is largely underestimated in the literature data: An approach to quantification of the missing proanthocyanidins. Food Research International, 42(10), 1381-1388.

Pérez-Magariño, S., \& González-SanJosé, M. L. (2000). Effect of pectolytic enzymes on the composition of white grape musts and wines. Italian Journal of Food Science, 12(2), 153-162.

Pérez-Magariño, S., Ortega-Heras, M., Cano-Mozo, E., \& González-Sanjosé, M. L. (2009). The influence of oak wood chips, micro-oxygenation treatment, and grape variety on colour, and anthocyanin and phenolic composition of red wines. Journal of Food Composition and Analysis, 22(3), 204-211.

Pérez-Magariño, S., Revilla, I., Izcara, E., \& González-SanJosé, M. L. (1999). Discrimination of DO wine vintages as a function of chemical composition. Quimica Analitica, 18, 133-136.

Philip, T., \& Kuykendall, J. R. (1973). Changes in Titratable Acidity, ${ }^{\circ}$ Brix, Ph, Potassium Content, Malate and Tartrate During Berry Development of Thompson Seedless Grapes. Journal of Food Science, 38(5), 874-876. 
Pinelo, M., Fabbro, P. D., Manzocco, L., Nuñez, M. J., \& Nicoli, M. C. (2005). Optimization of continuous phenol extraction from Vitis vinifera byproducts. Food Chemistry, 92(1), 109-117.

Planinic, M., Aliakbarian, B., Perego, P., Greganic, K., Tomas, S., \& Bucic-Kojic, A. (2015). Influence of temperature and drying time on extraction yield of phenolic compounds from grape pomace variety "portogizac". Chemical and Biochemical Engineering Quarterly, 29(3), 343-350.

Poiana, M. A. (2012). Enhancing oxidative stability of sunflower oil during convective and microwave heating using grape seed extract. International Journal of Molecular Sciences, 13(7), 9240-9259.

Price, A., Díaz, P., Bañón, S., \& Garrido, M. D. (2013). Natural extracts versus sodium ascorbate to extend the shelf life of meat-based ready-to-eat meals. Food Science and Technology International, 19(5), 427-438.

Rababah, T. M., Ereifej, K. I., Alhamad, M. N., Al-Qudah, K. M., Rousan, L. M., AlMahasneh, M. A., Al-U'Datt, M. H., \& Yang, W. (2011a). Effects of green tea and grape seed and TBHQ on physicochemical properties of baladi goat meats. International Journal of Food Properties, 14(6), 1208-1216.

Rababah, T. M., Feng, H., Yang, W., Al-Mahasneh, M., Ereifej, K., \& Al-U'Datt, M. (2012a). Effect of grape seed extracts on physicochemical and sensory properties of goat meat cooked by conventional electric or microwave ovens. Food Science and Technology Research, 18(3), 325-332.

Rababah, T. M., Feng, H., Yang, W., \& Yücel, S. (2012b). Fortification of potato chips with natural plant extracts to enhance their sensory properties and storage stability. JAOCS, Journal of the American Oil Chemists' Society, 89(8), 14191425.

Rababah, T. M., Hettiarachchy, N. S., Horax, R., Cho, M. J., Davis, B., \& Dickson, J. (2006). Thiobarbituric acid reactive substances and volatile compounds in chicken breast meat infused with plant extracts and subjected to electron beam irradiation. Poultry Science, 85(6), 1107-1113.

Rababah, T. M., Over, K., Hettiarachchy, N. S., Horax, R., Eswaranandam, S., Davis, B., Dickson, J., \& Niebuhr, S. (2010). Infusion of plant extracts during processing to preserve quality attributes of irradiated chicken breasts over 9 months storage at -20C. Journal of Food Processing and Preservation, 34(SUPPL. 1), 287-307.

Rababah, T. M., Yücel, S., Ereifej, K. I., Alhamad, M. N., Al-Mahasneh, M. A., Yang, W., Muhammad, A. U. H., \& Ismaeal, K. (2011b). Effect of grape seed extracts on the physicochemical and sensory properties of corn chips during storage. JAOCS, Journal of the American Oil Chemists' Society, 88(5), 631-637.

Raeisi, M., Tajik, H., Aliakbarlu, J., \& Valipour, S. (2014). Effect of carboxymethyl cellulose edible coating containing Zataria multiflora essential oil and grape seed extract on chemical attributes of rainbow trout meat. Veterinary Research Forum : an International Quarterly Journal, 5(2), 89-93. 
Reddy, G. V. B., Sen, A. R., Nair, P. N., Reddy, K. S., Reddy, K. K., \& Kondaiah, N. (2013). Effects of grape seed extract on the oxidative and microbial stability of restructured mutton slices. Meat Science, 95(2), 288-294.

Revilla, I., \& González-SanJosé, M. L. (2002). Multivariate evaluation of changes induced in red wine characteristics by the use of extracting agents. Journal of Agricultural and Food Chemistry, 50(16), 4525-4530.

Rhodes, P. L., Mitchell, J. W., Wilson, M. W., \& Melton, L. D. (2006). Antilisterial activity of grape juice and grape extracts derived from Vitis vinifera variety Ribier. International Journal of Food Microbiology, 107(3), 281-286.

Ribeiro, B., Cardoso, C., Silva, H. A., Serrano, C., Ramos, C., Santos, P. C., \& Mendes, R. (2013). Effect of grape dietary fibre on the storage stability of innovative functional seafood products made from farmed meagre (Argyrosomus regius). International Journal of Food Science and Technology, 48(1), 10-21.

Ribéreau-Gayon, P., Glories, Y., Maujean, A., \& Dubourdieu, D. (2006). Handbook of Enology: The Chemistry of Wine Stabilization and Treatments. (pp. 429-441): John Wiley \& Sons, Ltd.

Ricardo-Da-Silva, J. M., Bourzeix, M., Cheynier, V., \& Moutounet, M. (1991). Procyanidin composition of Chardonnay, Mauzac and Grenache blanc grapes. . Vitis, 30(3), 245-252.

Robredo, L. M., Junquera, B., González-SanJosé, M. L., \& Barrón, L. J. R. (1991). Biochemical events during ripening of grape berries. Italian Journal of Food Science, 3, 173-180.

Rodríguez, H., Curiel, J. A., Landete, J. M., de las Rivas, B., de Felipe, F. L., GómezCordovés, C., Mancheño, J. M., \& Muñoz, R. (2009). Food phenolics and lactic acid bacteria. International Journal of Food Microbiology, 132(2-3), 79-90.

Rodríguez, R., Jiménez, A., Fernández-Bolaños, J., Guillén, R., \& Heredia, A. (2006).

Dietary fibre from vegetable products as source of functional ingredients. Trends in Food Science \& Technology, 17(1), 3-15.

Rodríguez Vaquero, M. J., Aredes Fernández, P. A., Manca de Nadra, M. C., \& Strasser de Saad, A. M. (2010). Phenolic Compound Combinations on Escherichia coli Viability in a Meat System. Journal of Agricultural and Food Chemistry, 58(10), 6048-6052.

Rogiers, S. Y., Greer, D. H., Hatfield, J. M., Orchard, B. A., \& Keller, M. (2006). Mineral sinks within ripening grape berries (Vitis vinifera L.). Vitis - Journal of Grapevine Research, 45(3), 115-123.

Rohm, H., Brennan, C., Turner, C., Günther, E., Campbell, G., Hernando, I., Struck, S., \& Kontogiorgos, V. (2015). Adding Value to Fruit Processing Waste: Innovative Ways to Incorporate Fibers from Berry Pomace in Baked and Extruded Cereal-based Foods-A SUSFOOD Project. Foods, 4(4), 690.

Rojas, M. C., \& Brewer, M. S. (2007). Effect of Natural Antioxidants on Oxidative Stability of Cooked, Refrigerated Beef and Pork. Journal of Food Science, 72(4), S282-S288. 
Rojas, M. C., \& Brewer, M. S. (2008). Effect of natural antioxidants on oxidative stability of frozen, vacuum-packaged beef and pork. Journal of Food Quality, 31(2), 173-188.

Rosales Soto, M. U., Brown, K., \& Ross, C. F. (2012). Antioxidant activity and consumer acceptance of grape seed flour-containing food products. International Journal of Food Science and Technology, 47(3), 592-602.

Rounds, L., Havens, C. M., Feinstein, Y., Friedman, M., \& Ravishankar, S. (2012). Plant extracts, spices, and essential oils inactivate Escherichia coli O157:H7 and reduce formation of potentially carcinogenic heterocyclic amines in cooked beef patties. Journal of Agricultural and Food Chemistry, 60(14), 3792-3799.

Ruberto, G., Renda, A., Daquino, C., Amico, V., Spatafora, C., Tringali, C., \& Tommasi, N. D. (2007). Polyphenol constituents and antioxidant activity of grape pomace extracts from five Sicilian red grape cultivars. Food Chemistry, 100(1), 203-210.

Rüdel, R., Lehmann-Horn, F., Ricker, K., \& Küther, G. (1984). Hypokalemic periodic paralysis: In vitro investigation of muscle fiber membrane parameters. Muscle \& Nerve, 7(2), 110-120.

Ryu, K. S., Shim, K. S., \& Shin, D. (2014). Effect of grape pomace powder addition on TBARS and color of cooked pork sausages during storage. Korean Journal for Food Science of Animal Resources, 34(2), 200-206.

Sagdic, O., Ozturk, I., Cankurt, H., \& Tornuk, F. (2012a). Interaction Between Some Phenolic Compounds and Probiotic Bacterium in Functional Ice Cream Production. Food and Bioprocess Technology, 5(8), 2964-2971.

Sagdic, O., Ozturk, I., \& Kisi, O. (2012b). Modeling antimicrobial effect of different grape pomace and extracts on $\mathrm{S}$. aureus and E. coli in vegetable soup using artificial neural network and fuzzy logic system. Expert Systems with Applications, 39(8), 6792-6798.

Sagdic, O., Ozturk, I., Yilmaz, M. T., \& Yetim, H. (2011). Effect of Grape Pomace Extracts Obtained from Different Grape Varieties on Microbial Quality of Beef Patty. Journal of Food Science, 76(7), M515-M521.

Sánchez-Alonso, I., Borderías, J., Larsson, K., \& Undeland, I. (2007a). Inhibition of Hemoglobin-Mediated Oxidation of Regular and Lipid-Fortified Washed Cod Mince by a White Grape Dietary Fiber. Journal of Agricultural and Food Chemistry, 55(13), 5299-5305.

Sánchez-Alonso, I., Jiménez-Escrig, A., Saura-Calixto, F., \& Borderías, A. J. (2006). Effect of grape antioxidant dietary fibre on the prevention of lipid oxidation in minced fish: Evaluation by different methodologies. Food Chemistry, 101(1), 372-378.

Sánchez-Alonso, I., Jiménez-Escrig, A., Saura-Calixto, F., \& Borderías, A. J. (2008). Antioxidant protection of white grape pomace on restructured fish products during frozen storage. LWT - Food Science and Technology, 41(1), 42-50.

Sánchez-Alonso, I., Solas, M. T., \& Borderías, A. J. (2007b). Physical Study of Minced Fish Muscle with a White-Grape By-Product Added as an Ingredient. Journal of Food Science, 72(2), E94-E101. 
Sasse, A., Colindres, P., \& Brewer, M. S. (2009). Effect of natural and synthetic antioxidants on the oxidative stability of cooked, frozen pork patties. Journal of Food Science, 74(1), S30-S35.

Saura-Calixto, F. (2012). Concept and health-related properties of nonextractable polyphenols: The missing dietary polyphenols. Journal of Agricultural and Food Chemistry, 60(45), 11195-11200.

Saura-Calixto, F., \& García-Laurrari, J. A. (1999). Concentrado de fibra dietetica antioxidante natural de uva y su procedimiento de obtencion. WO 1999025209 Al(PCT/ES1998/000305).

Saura-Calixto, F., Goñi, I., Mañas, E., \& Abia, R. (1991). Klason lignin, condensed tannins and resistant protein as dietary fibre constituents: Determination in grape pomaces. Food Chemistry, 39(3), 299-309.

Sáyago-Ayerdi, S. G., Brenes, A., \& Goñi, I. (2009). Effect of grape antioxidant dietary fiber on the lipid oxidation of raw and cooked chicken hamburgers. LWT - Food Science and Technology, 42(5), 971-976.

Scalbert, A. (1991). Antimicrobial properties of tannins. Phytochemistry, 30(12), 38753883.

Schevey, C. T., \& Brewer, M. S. (2015). Effect of natural antioxidants and lipid model system on lipid oxidation. Journal of Food Quality, 38(1), 40-52.

Schevey, C. T., Toshkov, S., \& Brewer, M. S. (2013). Effect of natural antioxidants, irradiation, and cooking on lipid oxidation in refrigerated, salted ground beef patties. Journal of Food Science, 78(11), S1793-S1799.

Schillinger, U., Holzapfel, W. H., \& Björkroth, K. J. (2006). Lactic acid bacteria. C. d. W. Blackburn (Ed.), Food Spoilage Microorganisms, (pp. 541-578). Cambridge, England: Woodhead Publishing Limited.

Selani, M. M., Contreras-Castillo, C. J., Shirahigue, L. D., Gallo, C. R., Plata-Oviedo, M., \& Montes-Villanueva, N. D. (2011). Wine industry residues extracts as natural antioxidants in raw and cooked chicken meat during frozen storage. Meat Science, 88(3), 397-403.

Shaker, E. S. (2006). Antioxidative effect of extracts from red grape seed and peel on lipid oxidation in oils of sunflower. LWT - Food Science and Technology, 39(8), 883-892.

Shan, B., Cai, Y. Z., Brooks, J. D., \& Corke, H. (2011). Potential application of spice and herb extracts as natural preservatives in cheese. Journal of Medicinal Food, 14(3), 284-290.

Shelef, L. A. (1984). Antimicrobial effects of spices. Journal of Food Safety, 6(1), 2944.

Shi, C., Cui, J., Yin, X., Luo, Y., \& Zhou, Z. (2014). Grape seed and clove bud extracts as natural antioxidants in silver carp (Hypophthalmichthys molitrix) fillets during chilled storage: Effect on lipid and protein oxidation. Food Control, 40(1), 134-139.

Shibambo, S. L. (2008). The anti-fungal and anti-oxidant properties of polyphenols extracted from the resurrection plant, Myrothamnus flabellifolia. University of Cape Town. 
Shirahigue, L. D., Contreras-Castillo, C. J., Selani, M. M., Nadai, A. P., Mourão, G. B., \& Gallo, C. R. (2011). Winery grape-residue extract: Effects on quality and sensory attributes of cooked chicken meat. Food Science and Biotechnology, 20(5), 1257-1264.

Shirahigue, L. D., Plata-Oviedo, M., de Alencar, S. M., Bismara Regitano d'Arce, M. A., Ferreira de Souza Vieira, T. M., Cadorin Oldoni, T. L., \& ContrerasCastillo, C. J. (2010). Wine industry residue as antioxidant in cooked chicken meat. International Journal of Food Science and Technology, 45(5), 863-870.

Shrikhande, A. J. (2000). Wine by-products with health benefits. Food Research International, 33(6), 469-474.

Silván, J. M., Mingo, E., Hidalgo, M., de Pascual-Teresa, S., Carrascosa, A. V., \& Martinez-Rodriguez, A. J. (2013). Antibacterial activity of a grape seed extract and its fractions against Campylobacter spp. Food Control, 29(1), 25-31.

Simopoulos, A. P. (1999). Essential fatty acids in health and chronic disease. The American Journal of Clinical Nutrition, 70(3), 560s-569s.

Sivarooban, T., Hettiarachchy, N. S., \& Johnson, M. G. (2008). Physical and antimicrobial properties of grape seed extract, nisin, and EDTA incorporated soy protein edible films. Food Research International, 41(8), 781-785.

Smith, I., \& Yu, J. (2015). Nutritional and Sensory Quality of Bread Containing Different Quantities of Grape Pomace from Different Grape Cultivars. EC Nutrition, 2(1), 291-301.

Soladoye, O. P., Juárez, M. L., Aalhus, J. L., Shand, P., \& Estévez, M. (2015). Protein Oxidation in Processed Meat: Mechanisms and Potential Implications on Human Health. Comprehensive Reviews in Food Science and Food Safety, 14(2), 106-122.

Souquet, J.-M., Cheynier, V., Brossaud, F., \& Moutounet, M. (1996). Polymeric proanthocyanidins from grape skins. Phytochemistry, 43(2), 509-512.

Soysal, C. (2009). Effects of green tea extract on "golden delicious" apple polyphenoloxidase and its browning. Journal of Food Biochemistry, 33(1), 134148.

Spigno, G., \& De Faveri, D. M. (2007). Antioxidants from grape stalks and marc: Influence of extraction procedure on yield, purity and antioxidant power of the extracts. Journal of Food Engineering, 78(3), 793-801.

Sui, Y., Yang, J., Ye, Q., Li, H., \& Wang, H. (2014). Infrared, Convective, and Sequential Infrared and Convective Drying of Wine Grape Pomace. Drying Technology, 32(6), 686-694.

Sun, H., Lv, H., Yuan, G., \& Fang, X. (2014). Effect of grape seed extracts on the melanosis and quality of pacific white shrimp (Litopenaeus vannamei) during iced storage. Food Science and Technology Research, 20(3), 671-677.

Surh, J., \& Koh, E. (2014). Effects of four different cooking methods on anthocyanins, total phenolics and antioxidant activity of black rice. Journal of the Science of Food and Agriculture, 94(15), 3296-3304.

Tajik, H., Aminzare, M., Mounesi Raad, T., Hashemi, M., Hassanzad Azar, H., Raeisi, M., \& Naghili, H. (2015). Effect of Zataria multiflora Boiss Essential Oil and 
Grape Seed Extract on the Shelf Life of Raw Buffalo Patty and Fate of Inoculated Listeria monocytogenes. Journal of Food Processing and Preservation.

Taylor, V. F., Longerich, H. P., \& Greenough, J. D. (2003). Multielement Analysis of Canadian Wines by Inductively Coupled Plasma Mass Spectrometry (ICP-MS) and Multivariate Statistics. Journal of Agricultural and Food Chemistry, 51(4), 856-860.

Teixeira, A., Baenas, N., Dominguez-Perles, R., Barros, A., Rosa, E., Moreno, D. A., \& Garcia-Viguera, C. (2014). Natural Bioactive Compounds from Winery ByProducts as Health Promoters: A Review. International Journal of Molecular Sciences, 15(9), 15638-15678.

Tesaki, S., Tanabe, S., Moriyama, M., Fukushi, E., Kawabata, J., \& Watanabe, M. (1999). Isolation and identification of an antibacterial compound from grape and its application to foods. Nippon Nogeikagaku Kaishi, 73(2), 125-128.

Thimothe, J., Bonsi, I. A., Padilla-Zakour, O. I., \& Koo, H. (2007). Chemical Characterization of Red Wine Grape (Vitis vinifera and Vitis Interspecific Hybrids) and Pomace Phenolic Extracts and Their Biological Activity against Streptococcus mutans. Journal of Agricultural and Food Chemistry, 55(25), 10200-10207.

Totlani, V. M., \& Peterson, D. G. (2005). Reactivity of Epicatechin in Aqueous Glycine and Glucose Maillard Reaction Models: Quenching of C2, C3, and C4 Sugar Fragments. Journal of Agricultural and Food Chemistry, 53(10), 41304135.

Tseng, A., \& Zhao, Y. (2012). Effect of Different Drying Methods and Storage Time on the Retention of Bioactive Compounds and Antibacterial Activity of Wine Grape Pomace (Pinot Noir and Merlot). Journal of Food Science, 77(9), H192H201.

Tseng, A., \& Zhao, Y. (2013). Wine grape pomace as antioxidant dietary fibre for enhancing nutritional value and improving storability of yogurt and salad dressing. Food Chemistry, 138(1), 356-365.

Ulbin-Figlewicz, N., Zimoch-Korzycka, A., \& Jarmoluk, A. (2014). Antibacterial Activity and Physical Properties of Edible Chitosan Films Exposed to Lowpressure Plasma. Food and Bioprocess Technology, 7(12), 3646-3654.

Vaithiyanathan, S., Naveena, B. M., Muthukumar, M., Girish, P. S., \& Kondaiah, N. (2011). Effect of dipping in pomegranate (Punica granatum) fruit juice phenolic solution on the shelf life of chicken meat under refrigerated storage $\left(4{ }^{\circ} \mathrm{C}\right)$. Meat Science, 88(3), 409-414.

Vaquero, M. J. R., Alberto, M. R., \& de Nadra, M. C. M. (2007). Antibacterial effect of phenolic compounds from different wines. Food Control, 18(2), 93-101.

Viegas, O., Amaro, L. F., Ferreira, I. M. P. L. V. O., \& Pinho, O. (2012). Inhibitory Effect of Antioxidant-Rich Marinades on the Formation of Heterocyclic Aromatic Amines in Pan-Fried Beef. Journal of Agricultural and Food Chemistry, 60(24), 6235-6240. 
Viegas, O., Yebra-Pimentel, I., Martínez-Carballo, E., Simal-Gandara, J., \& Ferreira, I. M. P. L. V. O. (2014). Effect of Beer Marinades on Formation of Polycyclic Aromatic Hydrocarbons in Charcoal-Grilled Pork. Journal of Agricultural and Food Chemistry, 62(12), 2638-2643.

Viuda-Martos, M., Fernández-López, J., Sayas-Barbera, E., Sendra, E., Navarro, C., \& Pérez-Álvarez, J. A. (2009). Citrus Co-Products as Technological Strategy to Reduce Residual Nitrite Content in Meat Products. Journal of Food Science, 74(8), R93-R100.

Wagh, R. V., Chatli, M. K., Ruusunen, M., Puolanne, E., \& Ertbjerg, P. (2015). Effect of various phyto-extracts on physico-chemical, colour, and oxidative stability of pork frankfurters. Asian-Australasian Journal of Animal Sciences, 28(8), 11781186.

Walker, R. M. (2013). Feasibility of developing wine grape pomace fortified baked goods for health promotion. Oregon State University, Oregon.

Wang, Y., Li, F., Zhuang, H., Chen, X., Li, L., Qiao, W., \& Zhang, J. (2015a). Effects of plant polyphenols and $\alpha$-tocopherol on lipid oxidation, residual nitrites, biogenic amines, and $\mathrm{N}$-nitrosamines formation during ripening and storage of dry-cured bacon. LWT - Food Science and Technology, 60(1), 199-206.

Wang, Y., Li, F., Zhuang, H., Li, L., Chen, X., \& Zhang, J. (2015b). Effects of plant polyphenols and $\alpha$-tocopherol on lipid oxidation, microbiological characteristics, and biogenic amines formation in dry-cured bacons. Journal of Food Science, 80(3), C547-C555.

WHO. (2011). Codex Alimentarius. In Milk and milk products, (pp. 7-8).

Williams, C. M. (2000). Dietary fatty acids and human health. Animal Research, 49(3), 165-180.

Wójciak, K. M., Dolatowski, Z. J., \& Okoń, A. (2011). The effect of water plant extracts addition on the oxidative stability of meat products. Acta Scientiarum Polonorum, Technologia Alimentaria, 10(2), 175-188.

Wong, P. Y. Y., \& Kitts, D. D. (2002). The effects of herbal pre-seasoning on microbial and oxidative changes in irradiated beef steaks. Food Chemistry, 76(2), 197-205.

Xia, E.-Q., Deng, G.-F., Guo, Y.-J., \& Li, H.-B. (2010). Biological Activities of Polyphenols from Grapes. International Journal of Molecular Sciences, 11(2), 622-646.

Xu, C., Yagiz, Y., Hsu, W.-Y., Simonne, A., Lu, J., \& Marshall, M. R. (2014). Antioxidant, Antibacterial, and Antibiofilm Properties of Polyphenols from Muscadine Grape (Vitis rotundifolia Michx.) Pomace against Selected Foodborne Pathogens. Journal of Agricultural and Food Chemistry, 62(28), 6640-6649.

Xu, C., Yagiz, Y., Marshall, S., Li, Z., Simonne, A., Lu, J., \& Marshall, M. R. (2015). Application of muscadine grape (Vitis rotundifolia Michx.) pomace extract to reduce carcinogenic acrylamide. Food Chemistry, 182, 200-208.

Yadav, D., Kumar, A., Kumar, P., \& Mishra, D. (2015). Antimicrobial properties of black grape (Vitis vinifera L.) peel extracts against antibiotic-resistant 
pathogenic bacteria and toxin producing molds. Indian Journal of Pharmacology, 47(6), 663-667.

Yerlikaya, P., \& Gokoglu, N. (2010). Inhibition effects of green tea and grape seed extracts on lipid oxidation in bonito fillets during frozen storage. International Journal of Food Science \& Technology, 45(2), 252-257.

Yu, H., Qin, C., Wu, X., Ge, Q., Wu, M., Wu, J., Wang, M., \& Wang, Z. (2013). Effect of grape seed and rosemary phenolics on protein oxidation in Chinese-style sausage. Journal of Food, Agriculture and Environment, 11(2), 231-236.

Zhou, T., Zhang, T., Liu, W., \& Zhao, G. (2011). Physicochemical characteristics and functional properties of grape (Vitis vinifera L.) seeds protein. International Journal of Food Science \& Technology, 46(3), 635-641.

Zhu, F., Cai, Y. Z., Ke, J., \& Corke, H. (2011). Dietary plant materials reduce acrylamide formation in cookie and starch-based model systems. Journal of the Science of Food and Agriculture, 91(13), 2477-2483. 



\title{
ChAPTER 2:
}

\author{
ANTIOXIDANT AND ANTIMICROBIAL \\ Properties of Wine By-Products AND \\ Their Potential USES IN THE FOOD
}

INDUSTRY 



\section{Presentación}

El aprovechamiento integral de los orujos de vinificación puede ser una de las alternativas que contribuya a la demandada "producción sostenible". El aprovechamiento integral del orujo supone una reducción real e importante del volumen de residuos generados, requiriendo en general menos energía, agua, etc., lo que supone reducir la huella hídrica y del carbono de la producción vitivinícola. No obstante, las propuestas de aprovechamiento integral de orujos de vinificación siguen siendo hoy en día escasas, (y lo eran aún más cuando se comenzó con el desarrollo de este estudio en la vendimia de 2011), por lo que se consideró interesante desarrollar propuestas de este tipo de aprovechamiento teniendo como objetivo el desarrollo de productos con aplicación en la industria alimentaria.

Este capítulo presenta una propuesta de aprovechamiento integral del orujo de vinificación a través de tres productos de composición y propiedades diferentes, debido a que se obtienen desde orujos completos, desde orujos libres de pepitas o desde las pepitas aisladas de los orujos.

\section{Resultados más relevantes}

Los tres productos presentaron un alto contenido en fibra, minerales y compuestos fenólicos, así como gran actividad antioxidante, siendo mayor en el caso del sazonador procedente del orujo libre de semillas. Además este producto mostró efecto bactericida, mientras que el procedente de las pepitas aceleró el crecimiento microbiano. 



\title{
Chapter 2: Antioxidant and Antimicrobial Properties of Wine By-
}

\section{Products and Their Potential Uses in the Food Industry}

\begin{abstract}
Wine pomace (WP) is one of the agricultural by-products that has received most attention from food scientists due to the wide range of interesting compounds that remain after the winemaking process. Different powdered products rich in phenolic compounds, with interesting antioxidant and antimicrobial activities were obtained from WP by applying processes that are both environmentally friendly and economically affordable for the food industry. The products obtained showed high global antioxidant activities (ABTS assay), successfully delayed the onset of lipid oxidation in the Rancimat test, and showed different antimicrobial properties. Products derived from seed-free WP showed bactericidal effects against total aerobic mesophilic bacteria (TAMB) and lactic acid bacteria (LAB) and inhibited Enterobacteriaceae growth completely. The product derived from whole WP presented bacteriostatic activity against the three microorganism groups tested, whereas the product obtained from grape seed promoted TAMB and LAB growth but delayed Enterobacteriaceae proliferation.
\end{abstract}
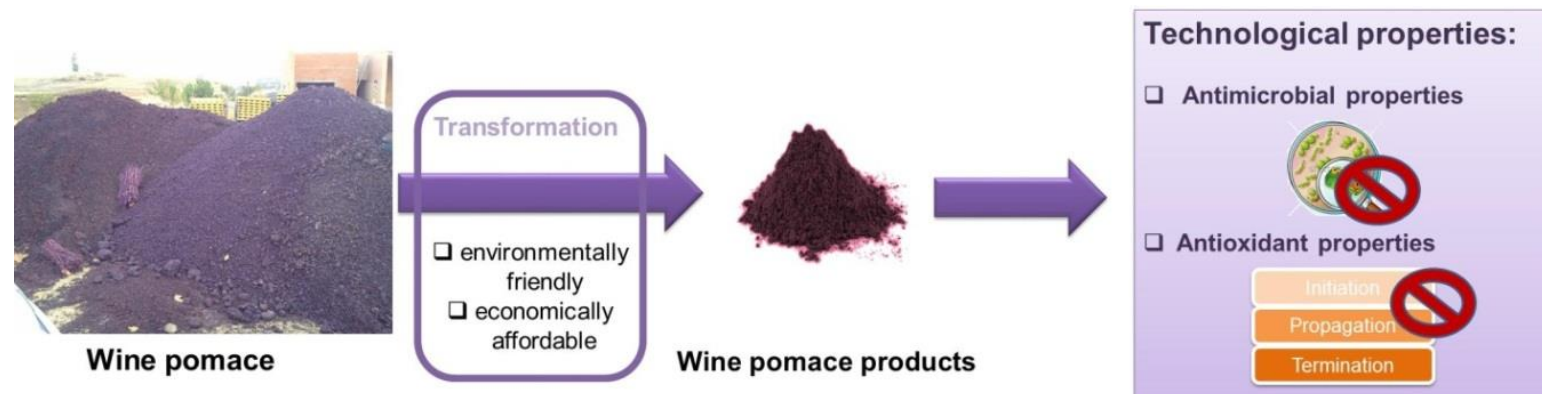

Source of fiber and potassium

Published in Journal of Agricultural and Food Chemistry, 2014, 62 (52), pp 1259512602. The final publication is available at pubs.acs.org/doi/10.1021/jf5042678 


\section{INTRODUCTION}

The food industry needs to extend the shelf-life of its products in order to reduce the amount of food that is wasted. The use of antioxidants and antimicrobials is therefore required in order to produce microbiologically safe foods while maintaining adequate sensory properties. Synthetic additives have traditionally been used due to their low price and high effectiveness (Brul \& Coote, 1999). However, consumer awareness concerning the potential risks of long-term intake of synthetic additives is increasing (Devcich et al., 2007). This fact has led the food industry to search for natural products that possess antioxidant and antimicrobial activity and can be used to replace synthetic additives in food formulations. Plant extracts and by-products from different industries have emerged as potential replacements for synthetic additives since they may exert similar effects and are preferred by consumers due to their natural nature. The preservative effects of such extracts have been attributed to their elevated content in bioactive compounds, including polyphenols, which are well-known antioxidants and antimicrobials (Brewer, 2011; Cowan, 1999).

The use or reuse of by-products, especially those from plant-based materials, presents several advantages such as the low cost of these by-products, reduced storage and elimination costs, their environmentally friendly nature, and revalorization of both the process and its by-products (Devesa-Rey et al., 2011). Wine pomace (WP) has been one of the most widely studied plant-based by-products for many years and many applications have been proposed for its revalorization, as recently reviewed by $\mathrm{Yu} \&$ Ahmedna (2013).

The solids remaining after the fermentation of red grapes, racking-off the wine, and subsequent pressure is usually known as WP, which mainly comprises solid grape 
parts (skin, rest of pulp and seeds) along with small pieces of stalk. WP also contents residual yeasts and bacteria which were the main agents to carry out alcoholic and malo-lactic fermentations. WP revalorization is usually approached by producing extracts rich in antioxidants, which can be incorporated into different food matrixes and also used in the cosmetics and pharmaceutical industries due to their antioxidant properties (Jongberg et al., 2011) and antimicrobial effects (Özkan et al., 2004). Although the use of these extracts is usually claimed to be a "green" alternative for the food industry, extracts are often obtained using organic solvents, thus meaning that this "green" status is questionable and could lead to their use in food formulations being refused (Chemat et al., 2012). Furthermore, extraction steps could considerably increase production costs and complicate broader applications in the food industry.

In addition to such extracts, other authors have proposed the use of wine byproducts without any prior extraction of the phenolic compounds, an approach that presents clear economic and environmental advantages (Devesa-Rey et al., 2011). The most widespread use of these products in the food industry is to increase the fiber and the global antioxidant capacity of the product they are added to (Yu \& Ahmedna, 2013). However, few studies have investigated the ability of such products to improve the stability of foodstuffs, and there is a lack of information regarding the effect of these products on the spoilage population of food systems. In light of the above, the main aim of this work was to evaluate the ability of products obtained directly from wine byproducts (specifically WP) to extend the shelf-life of foodstuffs by preventing oxidative degradation and controlling the growth of spoiler microorganisms. 


\section{MATERIALS AND METHODS}

\subsection{Material}

Wine pomaces from red winemaking were kindly supplied by seven different wineries located in the Burgos region. Wine pomaces from all wineries were well mixed and dehydrated to achieve a final water content of $<10 \%$.

Three products were obtained from the dry material: one from the global or whole wine pomace, termed "whole wine pomace product" (WWPP), another from the seed-free WP, termed "Skins wine pomace product" (SkWPP), and the third from the isolated seeds, termed "Seeds wine pomace product" (SdWPP). The dried materials were milled and sieved, and powdered products with particle sizes of less than 0.250 (SkWPP and WWPP) and $0.355 \mathrm{~mm}$ (SdWPP) were used to carry out this study. Ultraviolet (UV-C, $254 \mathrm{~nm})$ and thermal $\left(90^{\circ} \mathrm{C}\right)$ treatments were applied to inactivate the microbial flora present in the products obtained. Different heat and UV treatment times $(15,30,60,90$ and 120 minutes) were tested in order to reach the optimum microbial inactivation.

\subsection{Analytical Methodologies}

\subsubsection{Main composition analysis}

The moisture content was evaluated by the difference in the sample weight before and after drying at $105^{\circ} \mathrm{C}$ to constant weight. The fat content was determined after Soxhlet extraction using petroleum ether (Lab-Scan, Gliwice, Poland) as extraction solvent in a Buchi B-811 extraction system (Buchi, Switzerland). The protein content was determined using the Kjeldahl method, which measures the total nitrogen content after digestion with boiling sulfuric acid. A conversion factor of 6.25 was used to convert nitrogen into protein values. The total dietary fiber content was evaluated 
using the kit provided by Sigma (St Lois, USA) according to the manufacturer's instructions based on AOAC method 985.29. Total $\mathrm{SO}_{2}$ was determined using the enzymatic kit developed by R-Biopharm AG (Darmstadt, Germany) according to the manufacturer's instructions.

\subsubsection{Mineral content}

The ash content was determined by incineration of the samples at $525^{\circ} \mathrm{C}$ in a furnace (P-selecta, Barcelona, Spain). Sodium and potassium contents were determined according to the dry ashing method proposed by AOAC (2000) using flame photometry (Flame Photometer 410, Corning, UK), whereas the calcium content was measured in the same acid solution using a polarized Zeeman atomic absorption spectrophotometer Z-8200 (Hitachi; Japan). Phosphorus determinations were conducted by reaction of the acid solution with vanadate-molybdate reagent (Panreac, Barcelona, Spain) (Kitson \& Mellon, 1944).

\subsubsection{Main phenolic families}

Previously rehydrated powders were extracted in methanol/HCl (97:3) for 24 hours. The resulting extract was centrifuged and filtered. The content of four phenolic groups was determined: total polyphenol content (TPC) was determined by reaction with Folin-Ciocalteu reagent (Merck, Darmstadt, Germany) and expressed as mg of gallic acid per gram (Singleton \& Rossi, 1965), total catechin content (TCC) was determined by treatment with vanillin reagent (Sigma) and expressed as mg of Dcatechin per gram (Swain \& Hillis, 1959); total anthocyanin content (TAC) was quantified by measuring the difference in the absorbance $(525 \mathrm{~nm})$ of the sample diluted in $1 \mathrm{~N} \mathrm{HCl}$ and in phosphate citrate buffer (pH 3.5) (Paronetto, 1977) and the results expressed as mg of malvidin-3-glucoside per gram; and total proanthocyanidin 
content (TPAC) was measured after acid hydrolysis at $95^{\circ} \mathrm{C}$ for 40 minutes and expressed as mg of procyanidin B1 per gram (Porter et al., 1986).

\subsubsection{Antioxidant capacity}

$\boldsymbol{A B T S}^{+}$method: The radical scavenger activities of the powdered products were studied by measuring the decrease in the absorbance at $734 \mathrm{~nm}$ after incubation of methanolic extracts with a solution of ABTS (2,2'-azinobis-3-ethylbenzothiazoline-6sulfonic acid). The ABTS radical solution was prepared by mixing ABTS and $\mathrm{K}_{2} \mathrm{O}_{8} \mathrm{~S}_{2}$ in water (1:1) (Rivero-Pérez et al., 2007).

Fat oxidation inhibition capacity: The ability of the extracts to protect fats against oxidation was evaluated using the Rancimat test, which was performed using a Rancimat 743 Instrument (Metrohm, Switzerland). The air flow-rate and temperature were set at $20 \mathrm{~L} / \mathrm{h}$ and $110^{\circ} \mathrm{C}$ respectively. The tests were conducted in triplicate on commercial olive oil and melted pork lard. Controls and fats with $2 \%$ (w/w) of the different wine pomace products (WPPs) under study were conducted. The Rancimat test evaluates the conductivity caused by the short-chain fatty acids produced during lipid oxidation. Although this test has been criticized due to the use of high temperatures, which may affect the mechanism of lipid oxidation (Frankel, 1998), it remains a valuable tool for predicting the protection exerted by an antioxidant in real food systems. The results were expressed as protection factor, which was calculated by dividing the induction period of the WPPs with that for controls (fat without WPPs).

\subsubsection{Microbial analysis}

Samples were weighed in a Stomacher bag, decimally diluted with Ringer solution (Oxoid, Basingstoke, Hampshire, UK) under sterile conditions and homogenized in a laboratory blender (Stomacher 400, Colworth, London, UK). Total 
aerobic mesophilic bacteria (TAMB) and total yeasts and moulds were evaluated on plate count agar (PCA) (Merck) and Sabouraud agar with chloramphenicol (Pronadisa, Madrid, Spain) respectively. PCA plates were incubated at $30^{\circ} \mathrm{C}$ for 72 hours and Sabouraud plates at $25^{\circ} \mathrm{C}$ for 7 days.

\subsubsection{Antimicrobial potential of products}

The antimicrobial capacity was measured using meat homogenates, which were prepared by homogenizing commercially available beef in sterile water (1:3). A comparative study was carried out using homogenates of control meat (additive-free), meat with $2 \%$ of each WPP, and meat with $300 \mathrm{ppm}$ of $\mathrm{SO}_{2}$. Homogenates were incubated while stirring for 32 hours in an incubator (New Brunswick Scientific, Edison, U.S.A.) at $37^{\circ} \mathrm{C}$. For each sample, decimal dilutions were prepared in Ringer solution and plated onto the appropriate culture medium. TAMB were determined using pour plates on PCA after incubation at $30{ }^{\circ} \mathrm{C}$ for $72 \mathrm{~h}$. Lactic acid bacteria (LAB) were enumerated using de Man, Rogosa, Sharpe (MRS) agar (Oxoid) after incubation at $25^{\circ} \mathrm{C}$ in an atmosphere of $5 \% \mathrm{CO}_{2}$ for 5 days. Those colonies that reacted positively to the catalase test were not counted. Enterobacteriaceae counts were determined using a double layer of violet red bile glucose agar (Pronadisa) incubated at $37^{\circ} \mathrm{C}$ for 24 hours. Antimicrobial experiments were repeated three different times with duplicate homogenates each time.

\subsection{Statistical analysis}

Statistical analysis was performed using StatGraphics ${ }^{\circledR}$ Centurion XVI. Fisher's least significant difference (LSD) test was performed in order to identify significant differences. 


\section{RESULTS AND DISCUSSION}

WP presents a sufficiently high water content to promote both microbial growth and enzyme-related degradation, therefore a dehydration process was required in order to obtain a raw material that remains stable until final transformation into the desired powder products. Thermal drying was chosen over freeze-drying for the following reasons. Previous studies have suggested that, in contrast to freeze-drying, oven drying does not affect total extractable polyphenols and condensed tannins as long as the temperature does not exceed $60^{\circ} \mathrm{C}$ (Larrauri et al., 1997). Tseng \& Zhao (2012) reported that freeze-dried products had the lowest stability during storage, probably due to their higher porosity and higher exposure to oxygen. Furthermore, the costs of freeze-drying, which is estimated to be 4-8 times more expensive than thermal drying (Ratti, 2001), was also considered. WP was dehydrated to a water content of $<10 \%$.

Particle size determines the use and application of different ingredients in food manufacture (Huang et al., 2005). The handling safety of the ingredient, palatability of the resulting foodstuff, and the release of active compounds are some of the factors involved in this aspect. Furthermore, stability of products and manufacturing costs need to be considered. The likelihood of oxidative reactions and microbiological contamination increases with the reduction of particle size. Besides, the manufacturing costs also increase, due to longer manufacturing times and higher energy levels required to obtain smaller particle size. To balance the advantages and drawbacks of a very small particle size, SkWPP and WWPP were milled and sieved through a mesh with a size of $0.250 \mathrm{~mm}$, whereas SdWPP was milled and sieved through a mesh with a size of 0.355 $\mathrm{mm}$. The reason for choosing a higher particle size in SdWPP was the low yield obtained using a size of $0.250 \mathrm{~mm}$. This could be explained by the caking and sticking of the seeds powder as a consequence of the high fat content of grape seeds. These 
phenomena are commonly found for dairy-based powders with high lipid contents. Surface fat may melt during the grinding process due to the temperature increase, which leads to the formation of fatty bridges between particles. When the temperature drops the fat solidifies, forming bridges between particles and resulting in a lumpy product (Buma, 1971; Wakiyama et al., 1992). Furthermore, the tough structure of grape seed endosperm (Xu et al., 2010) could also contribute to the low yield obtained.

\subsection{Characterization of the products obtained}

The three products obtained showed significant differences in terms of composition (Table 2.1.). Dietary fiber was the main component in all three products, with the highest content being found for SdWPP $( \pm 59 \%)$, probably due to the presence of lignin in the seeds. These results agree with those of Saura-Calixto et al. (1991) and Tseng \& Zhao (2012), who indicated that WP mainly contains insoluble fiber and, more specifically, Klason lignin. WP fiber is associated with a high amount of antioxidants, thus making it a valuable source of dietary antioxidant fiber (Saura-Calixto, 1998). Similar protein contents were found for SkWPP and WWPP $( \pm 14 \%$ and $13 \%$ respectively), with the value for SdWPP (12\%) being slightly lower due to the higher fiber and lipid content. Protein values were comparable to those obtained by other authors (Gül et al., 2013; Saura-Calixto, 1998). Similar differences in the content of the various components of WP (mainly between skins and seeds) have been described previously (Basalan et al., 2011; Gül et al., 2013; Tseng \& Zhao, 2012).

SkWPP showed the highest ash content $( \pm 14 \%)$, with the values obtained being similar to those reported for Spanish grape pomaces by Saura-Calixto (1998) thus indicating a high mineral content in grape skins. Potassium was the predominant macroelement, especially in the products derived from raw material containing grape 
skins ( $\pm 43 \mathrm{mg} / \mathrm{g}$ ), which correlates with the well-known high potassium content usually found in grape skins. It is widely accepted that during grape ripening, potassium accumulates in the skin and forms both soluble and insoluble salts with organic acids (Coombe, 1987). Seeds are considered to be the strongest sinks for calcium and phosphorous in grape berry which explains the higher content of these minerals observed in SdWPP in comparison to SkWPP (Rogiers et al., 2006). The low sodium levels detected also agree with the lack of accumulation of these mineral during grape ripening (Rogiers et al., 2006). The incorporation of sulfating agents is widespread in wineries due to the microbial and oxidative stability provided by them. However, sulfites were not detected in any of the WP products obtained. The phenolic composition of the obtained products (Table 2.2.) agrees with the well-known fact that grape seeds are a richer source of polyphenols, especially catechins and proanthocyanidins, than grape skins and that only grape skins contain a relevant amount of anthocyanins (Kammerer et al., 2004; Xia et al., 2010) .

Table 2.1. Proximate composition of skin wine pomace product (SkWWP), whole wine pomace products (WWPP) and seed wine pomace product (SdWPP). ${ }^{\mathrm{a}}$

\begin{tabular}{cccc}
\hline Parameter & SkWPP & WWPP & SdWPP \\
\hline Moisture (\%) & $6.78 \pm 0.43 \mathrm{a}$ & $7.12 \pm 0.25 \mathrm{a}, \mathrm{b}$ & $7.57 \pm 0.09 \mathrm{~b}$ \\
Total dietary fiber (\% DM) & $48.6 \pm 0.7 \mathrm{a}$ & $49.4 \pm 0.9 \mathrm{a}$ & $58.9 \pm 0.5 \mathrm{~b}$ \\
Total lipid (\% DM) & $3.69 \pm 0.07 \mathrm{a}$ & $10.61 \pm 0.18 \mathrm{~b}$ & $16.99 \pm 0.18 \mathrm{c}$ \\
Total protein (\% DM) & $14.35 \pm 0.81 \mathrm{~b}$ & $13.09 \pm 1.51 \mathrm{a}, \mathrm{b}$ & $12.04 \pm 0.21 \mathrm{a}$ \\
Ash (\% DM) & $14.37 \pm 0.27 \mathrm{c}$ & $10.73 \pm 0.13 \mathrm{~b}$ & $2.94 \pm 0.21 \mathrm{a}$ \\
\hline Potassium & $43.34 \pm 2.53 \mathrm{c}$ & $38.20 \pm 1.26 \mathrm{~b}$ & $4.39 \pm 0.13 \mathrm{a}$ \\
Calcium & $1.82 \pm 0.11 \mathrm{a}$ & $3.13 \pm 0.20 \mathrm{~b}$ & $3.4 \pm 0.27 \mathrm{~b}$ \\
Phosphorous & $1.93 \pm 0.11 \mathrm{a}$ & $2.57 \pm 0.18 \mathrm{~b}$ & $2.75 \pm 0.24 \mathrm{~b}$ \\
Sodium & $1.31 \pm 0.11 \mathrm{c}$ & $0.98 \pm 0.07 \mathrm{~b}$ & $0.12 \pm 0.02 \mathrm{a}$ \\
\hline
\end{tabular}

${ }^{\mathrm{a}}$ Different letters $(\mathrm{a}, \mathrm{b}, \mathrm{c})$ denotes significant differences (LSD test and $\left.\mathrm{P}<0.05\right)$ between products. Values are means \pm standard deviation of three replicate determinations. 
Table 2.2. Phenolic composition of untreated, UV-treated, thermally treated wine pomace products $^{\mathrm{a}}$

\begin{tabular}{|c|c|c|c|}
\hline & Untreated & UV-treated & Thermally treated \\
\hline \multicolumn{4}{|c|}{ Total polyphenol content (mg gallic acid/g) } \\
\hline SkWPP & $25.87 \pm 0.34 \mathrm{~b}$ & $23.95 \pm 0.27 \mathrm{a}$ & $24.43 \pm 0.15 \mathrm{a}$ \\
\hline WWPP & $32.49 \pm 0.26 \mathrm{c}$ & $27.13 \pm 0.11 \mathrm{a}$ & $30.62 \pm 0.45 \mathrm{~b}$ \\
\hline SdWPP & $42.72 \pm 0.79 \mathrm{~b}$ & $38.59 \pm 0.67 \mathrm{a}$ & $41.66 \pm 0.34 \mathrm{~b}$ \\
\hline \multicolumn{4}{|c|}{ Total catechin content (mg d-catechin/g) } \\
\hline SkWPP & $10.52 \pm 0.17 \mathrm{c}$ & $7.78 \pm 0.25 \mathrm{a}$ & $8.78 \pm 0.22 b$ \\
\hline WWPP & $18.86 \pm 0.49 \mathrm{c}$ & $14.16 \pm 0.36 \mathrm{a}$ & $16.93 \pm 0.33 \mathrm{~b}$ \\
\hline SdWPP & $33.44 \pm 1.29 \mathrm{c}$ & $26.22 \pm 0.92 \mathrm{a}$ & $30.25 \pm 0.36 b$ \\
\hline \multicolumn{4}{|c|}{ Total anthocyanin content (mg of malvidin-3-glucoside/g) } \\
\hline SkWPP & $3.38 \pm 0.13 b$ & $3.12 \pm 0.27 \mathrm{~b}$ & $2.47 \pm 0.10 \mathrm{a}$ \\
\hline WWPP & $1.42 \pm 0.06 \mathrm{~b}$ & $1.62 \pm 0.04 \mathrm{c}$ & $1.02 \pm 0.10 \mathrm{a}$ \\
\hline SdWPP & $0.18 \pm 0.02 \mathrm{~b}$ & $0.09 \pm 0.05 \mathrm{a}$ & $0.09 \pm 0.02 \mathrm{a}$ \\
\hline \multicolumn{4}{|c|}{ Total proanthocyanidin content (mg of procyanidin B1/g) } \\
\hline SkWPP & $43.45 \pm 0.79 \mathrm{c}$ & $35.92 \pm 1.63 \mathrm{a}$ & $39.62 \pm 1.03 \mathrm{~b}$ \\
\hline WWPP & $56.87 \pm 6.23 b$ & $46.90 \pm 1.63 \mathrm{a}$ & $51.37 \pm 1.60 \mathrm{a}, \mathrm{b}$ \\
\hline SdWPP & $81.43 \pm 11.52 \mathrm{a}$ & $77.36 \pm 3.33 \mathrm{a}$ & $76.67 \pm 1.61 \mathrm{a}$ \\
\hline
\end{tabular}

a Different letters $(a, b, c)$ denotes significant differences (LSD test and $\mathrm{P}<0.05)$ among treatments. SkWPP $=$ Skin wine pomace product, $\mathrm{WWPP}=$ Whole wine pomace product, SdWPP $=$ Seed wine pomace product. Values are means \pm standard deviation of three replicate determinations.

It should be noted that the obtained values are lower than those reported in grapes (Pérez-Magariño \& González-San José, 2004) but are in agreement with the quantity of phenolic compounds transferred from grapes to wine during red winemaking (Peynaud, 1984).

Control of the microbial load of the products obtained was considered both convenient and necessary in order to obtain the safe products required by the food 
industry. Despite their wide range of applications, the microbiological contribution of WP-derived ingredients to foodstuffs has been underestimated as it has been assumed that the drying process is sufficient to ensure the safety of the powdered products (Walpole, 2008). However, other agricultural products with similar water contents and water activities, such as herbs and spices, have been involved in different outbreaks of food poisoning caused by the presence of pathogens (Vij et al., 2006). Moreover, it is also important to consider that fungi are able to produce mycotoxins even at low water activities (Romagnoli et al., 2007).

Our results showed that SkWPP had the highest microbial load, most likely due to the higher degree of manipulation and exposure to microbial contamination (Table 2.3.). Although the microbial load observed is usually considered to be acceptable in spices (Debevere, 2006), microbial inactivation is recommended to ensure the quality of the powdered products obtained. Two inactivation methods were conducted: thermal treatment and UV treatment. Although thermal treatment is the most common means of inactivating microorganisms, the low thermal stability of phenolic compounds may limit its application in WP products. Ultraviolet radiation has been mainly applied in liquid foods, although its use has also been proposed in powdered products (Peyron et al., 2002). In addition, it has successfully been used in leafy vegetables and is a clean and relatively inexpensive alternative (Allende et al., 2006; Escalona et al., 2010). As such, it may be a valuable option for WP products.

Preliminary studies were conducted in order to establish the most efficient conditions for thermal and UV treatments. Firstly, the efficiencies of different UVtreatment times were tested. The differences between the microbial load of untreated and UV-treated WWPP and SdWPP were not significant (Table 2.3.). The highest 
effectiveness of UV treatment was observed for SkWPP. These differences in effectiveness could be due to the difference in the particle size of each type of product (Fine \& Gervais, 2004). A progressive reduction in microbial load of SkWPP was observed from 15 to 60 minutes of treatment, while no significant reduction was observed during the second hour (from 60 to 120 minutes) of UV treatment. Thus, after 60 minutes of UV treatment, SkWPP showed reductions of 1.16 and $1.26 \log \mathrm{CFU} / \mathrm{g}$ in the counts of TAMB and yeasts and moulds, respectively (Table 2.3.). The thermal treatment at $90{ }^{\circ} \mathrm{C}$ produced a progressive reduction in the microbial load of the three products under study. The complete inactivation of the studied microbial flora was achieved after 90 minutes of treatment.

Table 2.3. Microbial load of untreated, UV-treated and thermal-treated treated wine pomace products. Results are expressed as log CFU/g of each product ${ }^{\text {a }}$

\begin{tabular}{clllc}
\hline & Product & Untreated & UV-treated & $\begin{array}{c}\text { Thermally } \\
\text { treated }\end{array}$ \\
\hline $\begin{array}{c}\text { Total aerobic } \\
\text { mesophilic } \\
\text { bacteria }\end{array}$ & SkWPP & $4.65 \pm 0.06$ & $3.49 \pm 0.17$ & nd \\
& WWPP & $4.00 \pm 0.09$ & $3.95 \pm 0.06$ & nd \\
\hline $\begin{array}{c}\text { Yeasts and } \\
\text { moulds }\end{array}$ & SkWPP & $3.42 \pm 0.09$ & $2.16 \pm 0.02$ & nd \\
& WWPP & $1.75 \pm 0.21$ & $1.53 \pm 0.09$ & nd \\
\hline
\end{tabular}

${ }^{\mathrm{a}}$ nd: not detected. SkWPP $=$ Skin wine pomace product, WWPP = Whole wine pomace product, SdWPP $=$ Seed wine pomace product. Values are means \pm standard deviation of three replicates.

UV and thermally treated products showed similar main compositions to untreated ones, although some differences in phenolic composition were detected (Table 2.2.). WWPP showed the highest decrease in TPC (16\% in UV-treated and $6 \%$ in thermally treated), whereas the TPC of SkWPP was affected similarly by both treatments. In contrast, only UV treatment affected the TPC of SdWPP. The cause of 
this higher decrease in UV-treated samples might be the photodimerization and isomerization of phenolic compounds induced by UV radiation (Turner et al., 1993). Furthermore, UV radiation may also promote the formation of new linkages between hydroxycinnamic acids and lignin units (Peyron et al., 2002), thereby decreasing their extractability. As far as thermal processing is concerned, previous studies found no significant decrease after heating to $100^{\circ} \mathrm{C}$ for $250 \mathrm{~min}$ and even a significant increase at $150^{\circ} \mathrm{C}$ (Sólyom et al., 2014). This fact can be explained by the degradation of cellwall polysaccharide structures, thus facilitating polyphenol release and extractability from the matrix structure (Pinelo et al., 2006). Similarly, Chamorro et al. (2012) found no significant decrease in $\mathrm{TP}$ after thermal treatment at $100^{\circ} \mathrm{C}$ for 1 hour.

Catechin was one of the groups most affected by treatments $(26 \%$ after UV treatment and $17 \%$ after thermal treatment). Epimerization and autoxidation seem to be the most likely mechanism for catechin degradation. The observed degradation agrees with the rates reported by Volf et al. (2014). Thermal treatment produced the highest degradation in TAC (27\% in WWPP and SkWPP), which may be explained by the well-known thermal lability of anthocyanins (Zorić et al., 2014). Sólyom et al. (2014) reported degradation rates of $75 \%$ in similar thermal treatments of non-dehydrated WP. Water availability plays a key role in anthocyanin degradation and the low water activity of the studied products may explain the relatively limited degradation of anthocyanins observed in this study (Erlandson \& Wrolstad, 1972; Gradinaru et al., 2003). UV treatment did not decrease the TAC of either WWPP or SkWPP. Thermal and UV treatments produced similar decreases in the TPAC for all products studied (approximately 15\%). Previous literature data in this regard are contradictory. Significant reductions in TPAC levels were reported by Khanal et al. (2010) for grape pomace after thermal treatment at temperatures of $60{ }^{\circ} \mathrm{C}$ or higher. These authors 
observed degradation of the oligomeric procyanidins in WP upon increasing the temperature from $60{ }^{\circ} \mathrm{C}$ to $125^{\circ} \mathrm{C}$. In contrast, Chamorro et al. (2012) found no significant reductions after heating grape pomace at $100{ }^{\circ} \mathrm{C}$ for 60 minutes. Overall, thermal treatment produced less intense reductions in TPC, TCC and TPAC than UV treatment, whereas it affected TAC more extensively. These reductions can be considered acceptable since the WPPs obtained retain the vast majority of their phenols and their safety is markedly improved. Consequently, thermal treatment was selected as the best option and thermally stabilized products were used in the subsequent study of antioxidant and antimicrobial activities.

\subsection{Properties of interest for food industry applications}

In addition to use of the products obtained as a source of fiber, antioxidant, and possibly some minerals, such as potassium, WPPs exhibit other properties of interest to the food industry. In this regard, antioxidant and antimicrobial properties were considered to be of particular importance for application as natural food preservatives.

The ABTS method was used to evaluate the global antioxidant capacity of the products studied from amongst the large number of possibilities available due to its simplicity and the complete information provided by it (Rivero-Pérez et al., 2007). All WP products showed interesting antioxidant capacities but with statistically significant differences. SdWPP exhibited the highest antioxidant activity $(141.99 \pm 2.09 \mu \mathrm{mol} / \mathrm{g})$, followed by WWPP $(103.29 \pm 0.23 \mu \mathrm{mol} / \mathrm{g})$ and SkWPP $(75.65 \pm 1.98 \mu \mathrm{mol} / \mathrm{g})$. ABTS results were positively and strongly correlated with TPC, TCC and TPAC, as it is indicated by Pearson correlation coefficient, which showed values of $0.9951,0.9968$ and 0.987 , respectively. This fact agrees with the attribution of antioxidant activity to the phenolic composition of WP. For example, Bonilla et al. (1999) reported that gallic 
acid exerted the highest protection amongst all the phenols extracted from crushed grape pomace when added at the same concentration. Lafka et al. (2007) also concluded that catechins and gallic acid contents are the main factors that determine the antioxidant activity of WPPs.

Considering the importance of preventing fat oxidation in the food industry, the ability of the products obtained to protect against fat oxidation was evaluated using the Rancimat method. Two fat systems with different oxidation sensitivities (olive oil and pork lard) were used. Olive oil mainly contains unsaturated fatty acids, which are more susceptible to oxidation than the saturated fatty acids found in pork lard. However, olive oil also contains polyphenols and tocopherols with antioxidant activity, (Velasco \& Dobarganes, 2002) whereas pro-oxidants can be found in pork lard (Morris et al., 1950). Furthermore, both fats can be considered as good representatives of the different types of fat used in the food industry (plant and animal fats).

Olive oil and pork lard gave average induction times of 26.07 and 14.65 hours respectively. The three products studied delayed the onset of lipid oxidation in both types of fats (Table 2.4.). These results could be correlated to the global antioxidant capacities of the products, most likely to the phenol content. The protection exerted by SdWPP was significantly lower than that exerted by SkWPP despite their higher TPC, TCC and TPAC values. These findings are in agreement with the findings of Shaker (2006) who reported a higher inhibition for grape skin extracts in comparison to grape seed extracts when added to sunflower oils at the same polyphenol concentration.

The data obtained appear to indicate a key role for anthocyanins in the protection against lipid oxidation (Tamura \& Yamagami, 1994). The same authors found that grape skin anthocyanins present a higher protective capacity against lipid 
oxidation than catechin and $\alpha$-tocopherol at the same concentration. Although anthocyanins are not soluble in fat, their protective properties could be associated with their excellent ability to scavenge the free radicals formed during fat oxidation. Wine anthocyanins showed a particularly intense hydroxyl radical scavenging capacity, which was similar to their superoxide radical scavenging activity (Rivero-Pérez et al., 2008). Furthermore, the possible lipid oxidation of seed fat during the production and storage of SdWPP and WWPP should be also considered, due to the fact that the presence of oxidized fatty acids may initiate oil and fat oxidation (Zheng et al., 2014), counteracting the antioxidant effects of polyphenols.

Table 2.4. Protection factor of wine pomace products in olive oil and pork lard measured by Rancimat method ${ }^{\mathrm{a}}$.

\begin{tabular}{cccc}
\hline & SkWWP & WWPP & SdWPP \\
\hline Olive oil & $1.087 \pm 0.028 \mathrm{~b}$ & $1.061 \pm 0.026 \mathrm{a}, \mathrm{b}$ & $1.024 \pm 0.016 \mathrm{a}$ \\
Pork lard & $1.145 \pm 0.028 \mathrm{~b}$ & $1.086 \pm 0.036 \mathrm{a}, \mathrm{b}$ & $1.052 \pm 0.010 \mathrm{a}$ \\
\hline
\end{tabular}

Protection factor $=$ induction time of fat with product under study / induction time of control fat. Different letters $(a, b)$ denote significant differences (LSD test and $\mathrm{P}<0.05)$ among products. SkWPP $=$ Skin wine pomace product, WWPP $=$ Whole wine pomace product, SdWPP $=$ Seed wine pomace product. ${ }^{\text {a }}$ Values are means \pm standard deviation of three replicate determinations.

Antimicrobial activities were studied in meat homogenates since meat is a good system for studying spoiler growth. The inhibitory effect of the WP products on the growth of potential spoilage microorganisms was studied and compared with the antimicrobial effect of sulfites (Figure 2.1.), a standard and well-known antimicrobial food additive, as control. The antimicrobial activity of sulfites appears to be related to their ability to induce changes in protein structures. Other antimicrobial mechanisms of sulfites include blockage of transport, inhibition of glycolysis, nutrient destruction and inhibition of microbial metabolism (Cornelius \& Lilian, 2005). 

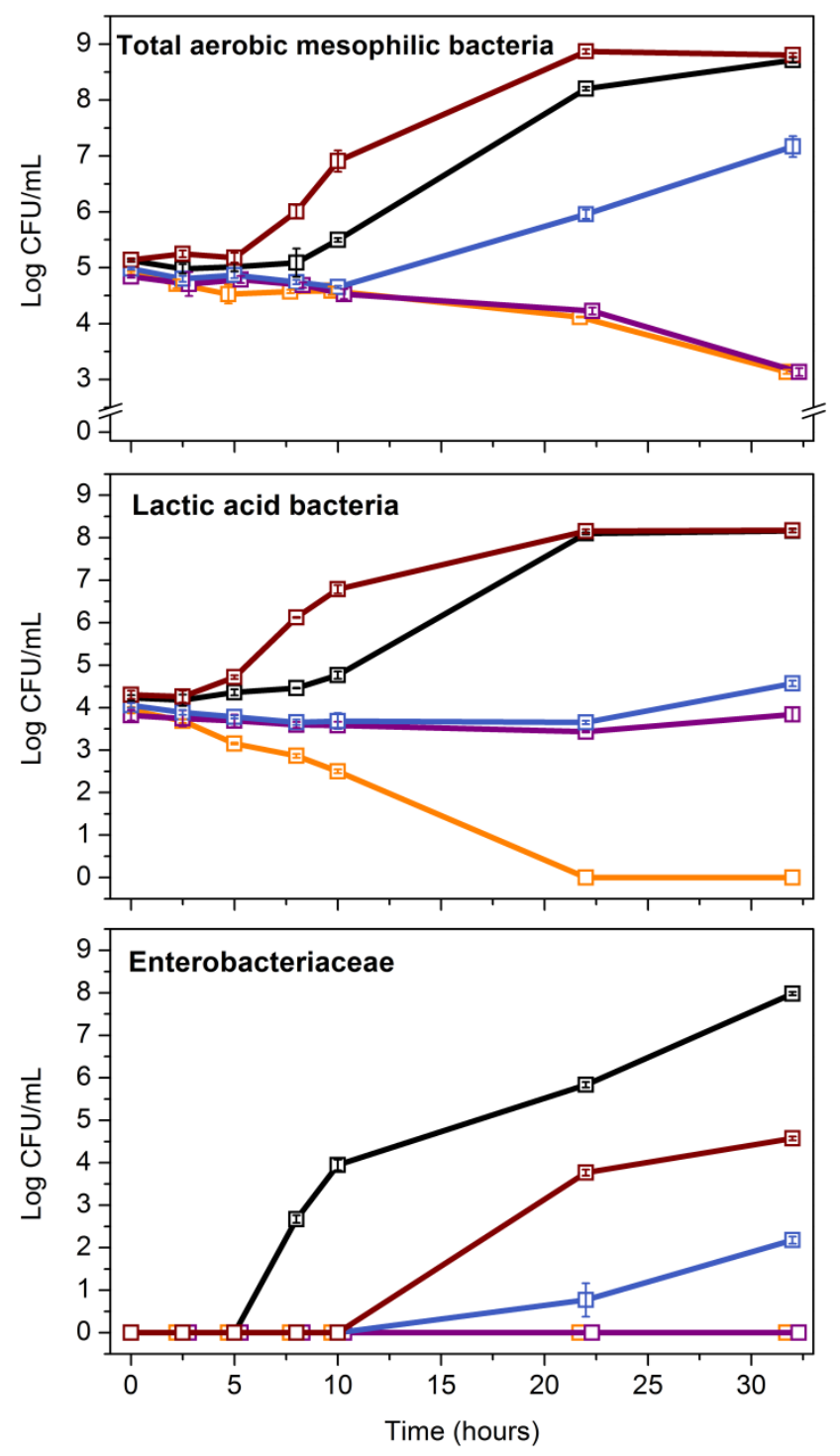

$\neg-$ Control $-\square-$ Sulfites $\square-$ SkWPP $\square-$ WWPP $\longrightarrow-$ SdWPP

Figure 2.1. Effect of incorporation of sulfites, skin wine pomace product (SkWPP), whole wine pomace product (WWPP) and seed wine pomace product (SdWPP) on the total aerobic mesophilic bacteria, lactic acid bacteria and Enterobacteriaceae counts of beef homogenates incubated at $37^{\circ} \mathrm{C}$.

Firstly, it is worth noting that the incorporation of SdWPP did not affect the initial load of homogenates, whereas addition of SkWPP, WWWP and sulfites produced an immediate decrease in TAMB and LAB counts. This finding suggests that the WP products obtained were in optimal conditions for use as food additives. Significant protective effects were detected for all three products studied, with these effects being very similar for all three assays performed. 
Meat homogenates incubated with sulfites exhibited a significant decrease in TAMB count, a complete inactivation of LAB after 32 hours of incubation, and no Enterobacteriaceae growth. SkWPP produced similar inhibitions of TAMB and Enterobacteriaceae growth to those produced by sulfites. The decrease in TAMB and LAB counts in the meat incubated with SkWPP suggests its bactericidal capacity. The addition of WWPP delayed the onset of TAMB and LAB growth (by 15 and 22 hours respectively), thereby confirming its bacteriostatic activity against spoilage flora. Moreover, addition of WWPP delayed Enterobacteriaceae growth and decreased the final counts in comparison with controls. These results could be correlated with the phenolic compounds present in SkWPP and WWPP. The effect of grape polyphenols on the growth of different meat spoiler microorganisms, such as LAB, has been widely studied and appears to depend on the polyphenol concentration, medium, and species (or even strains) under study (Reguant et al., 2000; Tabasco et al., 2011; Vivas et al., 1997).

The antimicrobial effects of plant materials containing phenolic compounds have been associated with different mechanisms of action (Cowan, 1999), such as the ability to inhibit cell wall synthesis, thereby producing cell membrane alterations and the consequent loss of crucial intracellular material; the ability to chelate essential metals such as iron; and the ability to bind polysaccharides and proteins, thereby producing compounds that cannot be metabolized by microorganisms (Chung et al., 1998). Furthermore, Friedman (2007) reported the ability to bind vital components in the cell, such as enzymes and cell transport proteins. Previous studies have shown an ability to increase the microbial stability of meat products but using grape pomace extracts. For instance, Sagdic et al. (2011) observed the inhibitory effect of ethanolic grape pomace extract on the spoiler growth of beef patties. The incorporation of high 
levels of grape pomace extracts $(10 \%)$ led to the complete inactivation of spoilage flora, whereas the addition of $1 \%$ grape pomace extract delayed the onset of microbial growth. The microbial results obtained with WWPP were worse than those obtained with SkWPP but better than those observed for SdWPP. The incorporation of SdWPP promoted the growth of TAMB and LAB and reduced their lag phases. These results were surprising in light of the higher phenolic content of this product. However, they are in agreement with the stimulatory role of grape seed extract on Lactobacillus acidophilus growth (Hervert-Hernández et al., 2009) and with the improved growth caused by gallic acid and catechin in Lactobacillus hilgardii (Rodríguez et al., 2008). Alberto et al. (2001) have suggested that polyphenols may improve sugar metabolism in LAB, thereby stimulating proliferation. The results obtained are satisfactory and novel.

From a microbial stability and spoilage protection point of view the best product was SkWPP, although WWPP also showed good results. Moreover, the results obtained upon addition of SdWPP were also interesting, especially considering that the promoting effect on $\mathrm{LAB}$ could result in an increase in the production of certain bacteriocins with antimicrobial activity against pathogens (Lewus et al., 1991). In addition, it has been found that the bacteriocins produced by gallic acid and catechin adapted LAB are particularly potent inhibitors of the growth of some food-borne pathogens such as Staphylococcus aureus and Salmonella enterica (Khalil, 2010).

\section{CONCLUSIONS}

In conclusion, wine pomace can be readily transformed into a series of products that meet the requirements of the food industry, namely cheap, environmentally friendly and natural, and with good antioxidant and antimicrobial abilities. Furthermore, these products can be used as a natural source of fiber, antioxidants and potassium. The 
bactericidal activity of SkWPP, which is similar to that for sulfites, suggests the possibility of using this product as a sulfite substitute, thereby reducing the allergenic risk. The ability of the products studied to inhibit fat oxidation also suggests potential applications in fatty food with a high tendency to rancidity, thereby extending their shelf life.

\section{REFERENCES}

Alberto, M. R., Farías, M. E., \& Manca de Nadra, M. C. (2001). Effect of Gallic Acid and Catechin on Lactobacillus hilgardii 5w Growth and Metabolism of Organic Compounds. Journal of Agricultural and Food Chemistry, 49(9), 4359-4363.

Allende, A., McEvoy, J. L., Luo, Y., Artes, F., \& Wang, C. Y. (2006). Effectiveness of two-sided UV-C treatments in inhibiting natural microflora and extending the shelf-life of minimally processed 'Red Oak Leaf' lettuce. Food Microbiology, 23(3), 241-249.

AOAC. (2000). Sodium and Potassium in Seafoods 969.23. Official methods of analysis (17th ed.).

Basalan, M., Gungor, T., Owens, F. N., \& Yalcinkaya, I. (2011). Nutrient content and in vitro digestibility of Turkish grape pomaces. Animal Feed Science and Technology, 169(3-4), 194-198.

Bonilla, F., Mayen, M., Merida, J., \& Medina, M. (1999). Extraction of phenolic compounds from red grape marc for use as food lipid antioxidants. Food Chemistry, 66(2), 209-215.

Brewer, M. S. (2011). Natural Antioxidants: Sources, Compounds, Mechanisms of Action, and Potential Applications. Comprehensive Reviews in Food Science and Food Safety, 10(4), 221-247.

Brul, S., \& Coote, P. (1999). Preservative agents in foods: Mode of action and microbial resistance mechanisms. International Journal of Food Microbiology, 50(1-2), 1-17.

Buma, T. J. (1971). Free fat in spray-dried whole milk. 5. cohesion; determination influence of particle size, moisture content and free-fat content. Nederlands melk- en zuiveltijdschrift, 25(2), 107-122.

Coombe, B. G. (1987). Distribution of Solutes within the Developing Grape Berry in Relation to Its Morphology. American Journal of Enology and Viticulture, 38(2), 120-127.

Cornelius, S. O., \& Lilian, W. (2005). Sulfur Dioxide and Sulfites. Antimicrobials in Food, Third Edition, (pp. 143-167): CRC Press.

Cowan, M. M. (1999). Plant Products as Antimicrobial Agents. Clinical Microbiology Reviews, 12(4), 564-582. 
Chamorro, S., Goñi, I., Hervert-Hernández, D., Viveros, A., \& Brenes, A. (2012). Changes in polyphenolic content and antioxidant activity after thermal treatments of grape seed extract and grape pomace. European Food Research and Technology, 234(1), 147-155.

Chemat, F., Vian, M. A., \& Cravotto, G. (2012). Green extraction of natural products: Concept and principles. International Journal of Molecular Sciences, 13(7), 8615-8627.

Chung, K. T., Lu, Z., \& Chou, M. W. (1998). Mechanism of inhibition of tannic acid and related compounds on the growth of intestinal bacteria. Food and Chemical Toxicology, 36(12), 1053-1060.

Debevere, J. (2006). Microbial Guide Values \& legal microbiological criteria. In U. Gent (Ed.)).

Devcich, D. A., Pedersen, I. K., \& Petrie, K. J. (2007). You eat what you are: Modern health worries and the acceptance of natural and synthetic additives in functional foods. Appetite, 48(3), 333-337.

Devesa-Rey, R., Vecino, X., Varela-Alende, J. L., Barral, M. T., Cruz, J. M., \& Moldes, A. B. (2011). Valorization of winery waste vs. the costs of not recycling. Waste Management, 31(11), 2327-2335.

Erlandson, J. A., \& Wrolstad, R. E. (1972). Degradation of anthocyanins at limited water concentration. Journal of Food Science, 37(4), 592-595.

Escalona, V. H., Aguayo, E., Martínez-Hernández, G. B., \& Artés, F. (2010). UV-C doses to reduce pathogen and spoilage bacterial growth in vitro and in baby spinach. Postharvest Biology and Technology, 56(3), 223-231.

Fine, F., \& Gervais, P. (2004). Efficiency of pulsed UV light for microbial decontamination of food powders. Journal of Food Protection, 67(4), 787-792.

Frankel, E. N. (1998). Free radical oxidation. E. N. Frankel (Ed.), Lipid oxidation. Dundee: The Oily Press.

Friedman, M. (2007). Overview of antibacterial, antitoxin, antiviral, and antifungal activities of tea flavonoids and teas. Molecular Nutrition and Food Research, 51(1), 116-134.

Gradinaru, G., Biliaderis, C. G., Kallithraka, S., Kefalas, P., \& Garcia-Viguera, C. (2003). Thermal stability of Hibiscus sabdariffa L. anthocyanins in solution and in solid state: effects of copigmentation and glass transition. Food Chemistry, 83(3), 423-436.

Gül, H., Acun, S., Şen, H., Nayir, N., \& Türk, S. (2013). Antioxidant activity, total phenolics and some chemical properties of Öküzgözü and Narince grape pomace and grape seed flour. Journal of Food Agriculture and Environment, 11(2), 28-34.

Hervert-Hernández, D., Pintado, C., Rotger, R., \& Goñi, I. (2009). Stimulatory role of grape pomace polyphenols on Lactobacillus acidophilus growth. International Journal of Food Microbiology, 136(1), 119-122. 
Huang, S. C., Shiau, C. Y., Liu, T. E., Chu, C. L., \& Hwang, D. F. (2005). Effects of rice bran on sensory and physico-chemical properties of emulsified pork meatballs. Meat Science, 70(4), 613-619.

Jongberg, S., Skov, S. H., Tørngren, M. A., Skibsted, L. H., \& Lund, M. N. (2011). Effect of white grape extract and modified atmosphere packaging on lipid and protein oxidation in chill stored beef patties. Food Chemistry, 128(2), 276-283.

Kammerer, D., Claus, A., Carle, R., \& Schieber, A. (2004). Polyphenol screening of pomace from red and white grape varieties (Vitis vinifera L.) by HPLC-DADMS/MS. Journal of Agricultural and Food Chemistry, 52(14), 4360-4367.

Khalil, R. S. (2010). Influence of gallic acid and catechin polyphenols on probiotic properties of Streptococcus thermophilus CHCC 3534 strain. World Journal of Microbiology and Biotechnology, 26(11), 2069-2079.

Khanal, R. C., Howard, L. R., \& Prior, R. L. (2010). Effect of heating on the stability of grape and blueberry pomace procyanidins and total anthocyanins. Food Research International, 43(5), 1464-1469.

Kitson, R. E., \& Mellon, M. G. (1944). Colorimetric determination of phosphorus as molybdivanadophosphoric acid. Industrial and Engineering Chemistry, 16(6), 379-383.

Lafka, T. I., Sinanoglou, V., \& Lazos, E. S. (2007). On the extraction and antioxidant activity of phenolic compounds from winery wastes. Food Chemistry, 104(3), 1206-1214.

Larrauri, J. A., Rupérez, P., \& Saura-Calixto, F. (1997). Effect of Drying Temperature on the Stability of Polyphenols and Antioxidant Activity of Red Grape Pomace Peels. Journal of Agricultural and Food Chemistry, 45(4), 1390-1393.

Lewus, C. B., Kaiser, A., \& Montville, T. J. (1991). Inhibition of food-borne bacterial pathogens by bacteriocins from lactic acid bacteria isolated from meat. Applied and Environmental Microbiology, 57(6), 1683-1688.

Morris, S. G., Myers, J. S., Jr., Kip, M., \& Riemenschneider, R. W. (1950). Metal deactivation in lard. Journal of the American Oil Chemists' Society, 27(3), 105107.

Özkan, G., Sagdiç, O., Baydar, N. G., \& Kurumahmutoglu, Z. (2004). Antibacterial activities and total phenolic contents of grape pomace extracts. Journal of the Science of Food and Agriculture, 84(14), 1807-1811.

Paronetto, L. (1977). Polifenoli e tecnica enologica. Milan, Italy: Selepress.

Pérez-Magariño, S., \& González-San José, M. L. (2004). Evolution of Flavanols, Anthocyanins, and Their Derivatives during the Aging of Red Wines Elaborated from Grapes Harvested at Different Stages of Ripening. Journal of Agricultural and Food Chemistry, 52(5), 1181-1189.

Peynaud, E. (1984). Knowing and Making Wine. New York: John Wiley \& Sons.

Peyron, S., Abecassis, J., Autran, J. C., \& Rouau, X. (2002). Influence of UV exposure on phenolic acid content, mechanical properties of bran, and milling behavior of durum wheat (triticum durum desf.). Cereal Chemistry, 79(5), 726-731. 
Pinelo, M., Arnous, A., \& Meyer, A. S. (2006). Upgrading of grape skins: Significance of plant cell-wall structural components and extraction techniques for phenol release. Trends in Food Science and Technology, 17(11), 579-590.

Porter, L. J., Hrstich, L. N., \& Chan, B. G. (1986). The conversion of procyanidins and prodelphinidins to cyanidin and delphinidin. Phytochemistry, 25(1), 223-230.

Ratti, C. (2001). Hot air and freeze-drying of high-value foods: A review. Journal of Food Engineering, 49(4), 311-319.

Reguant, C., Bordons, A., Arola, L., \& Rozès, N. (2000). Influence of phenolic compounds on the physiology of CEnococcus œni from wine. Journal of Applied Microbiology, 88(6), 1065-1071.

Rivero-Pérez, M. D., Muñiz, P., \& González-Sanjosé, M. L. (2007). Antioxidant profile of red wines evaluated by total antioxidant capacity, scavenger activity, and biomarkers of oxidative stress methodologies. Journal of Agricultural and Food Chemistry, 55(14), 5476-5483.

Rivero-Pérez, M. D., Muñiz, P., \& González-Sanjosé, M. L. (2008). Contribution of anthocyanin fraction to the antioxidant properties of wine. Food and Chemical Toxicology, 46(8), 2815-2822.

Rodríguez, H., Rivas, B. d. 1., Gómez-Cordovés, C., \& Muñoz, R. (2008). Degradation of tannic acid by cell-free extracts of Lactobacillus plantarum. Food Chemistry, 107(2), 664-670.

Rogiers, S. Y., Greer, D. H., Hatfield, J. M., Orchard, B. A., \& Keller, M. (2006). Mineral sinks within ripening grape berries (Vitis vinifera L.). Vitis, 45(3), 115123.

Romagnoli, B., Menna, V., Gruppioni, N., \& Bergamini, C. (2007). Aflatoxins in spices, aromatic herbs, herb-teas and medicinal plants marketed in Italy. Food Control, 18(6), 697-701.

Sagdic, O., Ozturk, I., Yilmaz, M. T., \& Yetim, H. (2011). Effect of Grape Pomace Extracts Obtained from Different Grape Varieties on Microbial Quality of Beef Patty. Journal of Food Science, 76(7), M515-M521.

Saura-Calixto, F. (1998). Antioxidant Dietary Fiber Product: A New Concept and a Potential Food Ingredient. Journal of Agricultural and Food Chemistry, 46(10), 4303-4306.

Saura-Calixto, F., Goñi, I., Mañas, E., \& Abia, R. (1991). Klason lignin, condensed tannins and resistant protein as dietary fibre constituents: Determination in grape pomaces. Food Chemistry, 39(3), 299-309.

Shaker, E. S. (2006). Antioxidative effect of extracts from red grape seed and peel on lipid oxidation in oils of sunflower. LWT - Food Science and Technology, 39(8), 883-892.

Singleton, V. L., \& Rossi, J. A., Jr. (1965). Colorimetry of Total Phenolics with Phosphomolybdic-Phosphotungstic Acid Reagents. American Journal of Enology and Viticulture, 16(3), 144-158.

Sólyom, K., Solá, R., Cocero, M. J., \& Mato, R. B. (2014). Thermal degradation of grape marc polyphenols. Food Chemistry, 159, 361-366. 
Swain, T., \& Hillis, W. E. (1959). The phenolic constituents of Prunus domestica. I.The quantitative analysis of phenolic constituents. Journal of the Science of Food and Agriculture, 10(1), 63-68.

Tabasco, R., Sánchez-Patán, F., Monagas, M., Bartolomé, B., Victoria Moreno-Arribas, M., Peláez, C., \& Requena, T. (2011). Effect of grape polyphenols on lactic acid bacteria and bifidobacteria growth: Resistance and metabolism. Food Microbiology, 28(7), 1345-1352.

Tamura, H., \& Yamagami, A. (1994). Antioxidative activity of monoacylated anthocyanins isolated from Muscat Bailey A grape. Journal of Agricultural and Food Chemistry, 42(8), 1612-1615.

Tseng, A., \& Zhao, Y. (2012). Effect of Different Drying Methods and Storage Time on the Retention of Bioactive Compounds and Antibacterial Activity of Wine Grape Pomace (Pinot Noir and Merlot). Journal of Food Science, 77(9), H192$\mathrm{H} 201$.

Turner, L. B., Mueller-Harvey, I., \& McAllan, A. B. (1993). Light-induced isomerization and dimerization of cinnamic acid derivatives in cell walls. Phytochemistry, 33(4), 791-796.

Velasco, J., \& Dobarganes, C. (2002). Oxidative stability of virgin olive oil. European Journal of Lipid Science and Technology, 104(9-10), 661-676.

Vij, V., Ailes, E., Wolyniak, C., Angulo, F. J., \& Klontz, K. C. (2006). Recalls of spices due to bacterial contamination monitored by the U.S. Food and Drug Administration: The predominance of salmonellae. Journal of Food Protection, 69(1), 233-237.

Vivas, N., Lonvaud-Funel, A., \& Glories, Y. (1997). Effect of phenolic acids and anthocyanins on growth, viability and malolactic activity of a lactic acid bacterium. Food Microbiology, 14(3), 291-300.

Volf, I., Ignat, I., Neamtu, M., \& Popa, V. I. (2014). Thermal stability, antioxidant activity, and photo-oxidation of natural polyphenols. Chemical Papers, 68(1), 121-129.

Wakiyama, N., Kusai, A., \& Nishimura, K. (1992). Mechanism of caking of granules containing oily materials. International Journal of Pharmaceutics, 78(2-3), 95102.

Walpole, M. (2008). Method of producing concentrated flour wine grape pomace. United States Patent Application Publication, W02008014609 Al(WO2008014609 A1).

Xia, E. Q., Deng, G. F., Guo, Y. J., \& Li, H. B. (2010). Biological activities of polyphenols from grapes. International Journal of Molecular Sciences, 11(2), 622-646.

$\mathrm{Xu}$, C., Zhang, Y., Wang, J., \& Lu, J. (2010). Extraction, distribution and characterisation of phenolic compounds and oil in grapeseeds. Food Chemistry, 122(3), 688-694. 
Yu, J., \& Ahmedna, M. (2013). Functional components of grape pomace: their composition, biological properties and potential applications. International Journal of Food Science and Technology, 48(2), 221-237.

Zheng, C., Deng, Q., Yang, M., Zhou, Q., \& Huang, F. (2014). The effect of heating on the physicochemical and quality characteristics of grape seed oil. Journal of Food Agriculture and Environment, 12(1), 73-79.

Zorić, Z., Dragović-Uzelac, V., Pedisić, S., Kurtanjek, Ž., \& Garofulić, I. E. (2014). Kinetics of the degradation of anthocyanins, phenolic acids and flavonols during heat treatments of freeze-dried sour cherry Marasca paste. Food Technology and Biotechnology, 52(1), 101-108. 


\section{ChAPTER 3 :}

Alternative Natural Seasoning to IMPROVE THE MICROBIAL STABILITY OF LOWSalt Beef Patties 



\section{Presentación}

El elevado consumo de sodio es una de las causas que contribuye al aumento de la tasa de enfermedades coronarias observada en las poblaciones occidentales. La principal fuente de sodio en la dieta de estas sociedades son los alimentos procesados. Es por ello que uno de los retos que afronta la industria alimentaria en general, y en particular la industria cárnica, es la reducción del contenido en sal de sus productos. Sin embargo, debido al efecto antimicrobiano de la sal, la reducción de sal conlleva el descenso de la vida útil de los productos. Para paliar este efecto se han desarrollado diferentes propuestas entre las que se encuentra la modificación de las formulaciones incorporando ingredientes con características sápidas y con actividad antimicrobiana como especias, algas, etc.

Dada la actividad antimicrobiana demostrada por el sazonador procedente del orujo libre de pepitas frente a los microorganismos alterantes descrita en el capítulo 2, y debido a sus características gustativas, se pensó en su posible uso como sazonador en hamburguesas con contenidos reducidos de sal. Así, en este capítulo se estudia el efecto de la incorporación de un $2 \%$ de dicho producto sobre la vida útil de hamburguesas con contenidos reducidos de sal.

\section{Resultados más relevantes}

El producto se mostró eficaz para reducir el aumento del deterioro microbiano debido a la reducción de sal. Adicionalmente, debido al aporte de potasio y a la reducción de la sal se redujo el valor de la relación sodio:potasio de las hamburguesas “mejorando" su composición desde el punto de vista del consumo de sodio y del riesgo coronario, al que también contribuye el aporte de antioxidantes y de fibra. 



\title{
Chapter 3: Alternative Natural Seasoning to Improve the Microbial
}

\section{Stability of Low-Salt Beef Patties}

\begin{abstract}
The meat industry is seeking new strategies to reduce the sodium content of meat products without shortening their shelf-life. Natural seasonings as salt alternatives are better appreciated than chemical preservatives and also enable the incorporation of interesting nutrients. The present work studies the potential of a new red wine pomace seasoning (RWPS), derived from wine pomace, to inhibit spoilage growth in beef patties with different salt levels $(2 \%, 1.5 \%$ and $1 \%)$ and stored at $4^{\circ} \mathrm{C}$. The use of RWPS $(2 \% \mathrm{w} / \mathrm{w})$ improved the microbial stability of the patties, delaying total aerobic mesophilic and lactic acid bacteria growth, especially in samples with low-salt levels. Satisfactory results were obtained in modified-atmosphere and air-packaged patties. RWPS also improved the nutrient composition of patties, increasing their levels of potassium, calcium, fiber and phenolic compounds. RWPS presented an interesting potential as seasoning in meat products, enabling salt reduction without compromising their microbial stability.
\end{abstract}

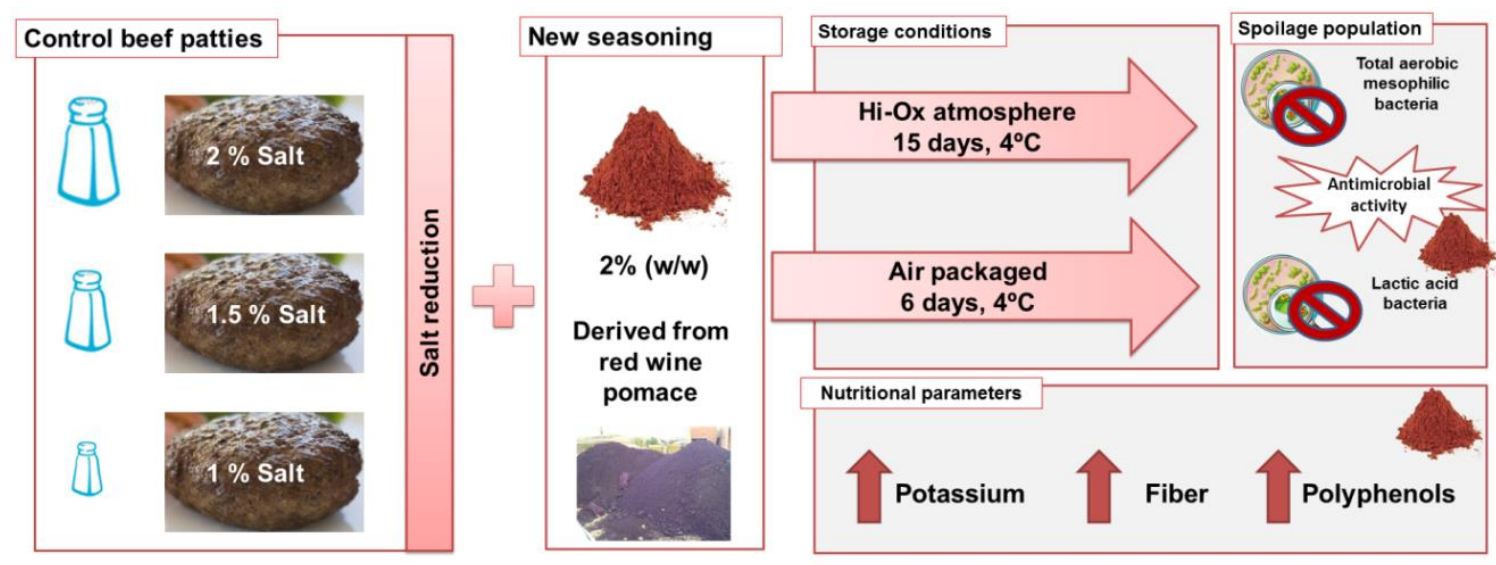




\section{INTRODUCTION}

The excessive current salt intakes in Europe (between 8 and 12 grams per day) are strongly correlated with several chronic diseases, mainly cardiovascular diseases (Doyle \& Glass, 2010; Perez \& Chang, 2014). Processed foods account for $80 \%$ of salt intake, which highlights the relevance of providing the food industry with new alternatives to reduce the amount of added salt in processed food (EuropeanComission, 2012).

Meat and meat products are one of the most widely consumed food categories in Western diets. Meat, per se, is poor in sodium, however meat products contribute to approximately $20 \%$ of daily sodium intake (Desmond, 2006) due to the addition of sodium chloride (common salt) during meat processing. In addition to the sensory aspects, salt acts as a preservative in meat products, as it decreases their water activity and induces osmotic stress in microorganisms (Doyle \& Glass, 2010). Consequently, reducing salt levels of meat products, without using any other preservative, shorts their shelf-life (Devlieghere et al., 2009; Doyle \& Glass, 2010). The use of chemical preservatives such as sulfites, nitrites and sorbates, is subject to increasing regulation and, in some cases, even forbidden, due to their effects on the nutritional value of meat products. Furthermore, their presence in the label may lead consumer to reject the product (Devcich et al., 2007). Salt reduction is, therefore, a complex problem and many factors need to be balanced in order to achieve a satisfactory solution (Desmond, 2006).

The meat industry is constantly looking for new natural alternatives in order to produce low-salt meat products without shortening their shelf-life. Some alternatives have been previously described such as the substitution of salt by herbs and spices (Viuda-Martos et al., 2011), new seasonings from algae (Hotchkiss, 2012) and whey 
(Minasian, 2011), among others (Devlieghere et al., 2009). Some technological solutions applying high pressure processing have been also implemented (Yang et al., 2015). The use of alternative seasonings from plant materials presents several advantages, such as the incorporation of interesting vegetal components including fibers, antioxidants and minerals. These nutrients can improve the daily intake among consumers with low-levels of vegetable consumption, enhance the "healthy" image of meat products and improve consumer perspective towards them. Furthermore, the reutilization of food industry by-products improves the environmental efficacy of the food industries.

Recently, new seasonings derived from wine pomace have been developed using environmentally friendly and economically affordable procedures (González San José et al., 2015). These seasonings present antioxidant and antimicrobial activities, highly interesting for the food industry, as well as relevant quantities of fiber, phenolic compounds and some minerals such as potassium (Del Pino-García et al., 2015; GarcíaLomillo et al., 2014).

The main aim of this work was to evaluate the potential application of a new vegetal seasoning to improve the microbial stability of beef patties and especially those with low-salt levels.

\section{MATERIALS AND METHODS}

\subsection{Materials and chemicals}

Beef meat, especially sold for patty manufacturing, was obtained from a local supplier (Gros Mercat, Burgos, Spain). Common salt, food grade starch and a commercially available mixture of phosphates provided by Doscadesa (Murcia, Spain) and sodium metabisulfite $\left(\mathrm{Na}_{2} \mathrm{~S}_{2} \mathrm{O}_{5}\right)$ (Panreac, Barcelona, Spain) were used in the formulation of beef patties. A red wine pomace seasoning (RWPS) obtained from 
seedless red wine pomace (González San José et al., 2015) was prepared at the pilot plant of the Food Technology Department of University of Burgos (Spain).

Reagent-grade chemicals were used for chemical analyses. $\mathrm{HNO}_{3}$ from Merck (Darmstadt, Germany) and sodium, potassium and calcium standards from Panreac were used for the mineral quantification procedure. Petroleum ether was obtained from Lab-Scan (Gliwice, Poland) and Folin-Ciocalteu reagent from Merck. For microbial analysis, buffered peptone and plate count agar (PCA) were obtained from Merck, and de Man, Rogosa and Sharpe (MRS) agar was purchased from Oxoid (Basingstoke, Hampshire, UK).

\subsection{Patty preparation}

Beef meat was chopped and ground using a food mincer (Cato, Sabadell, Spain) for 5 minutes. The patty base-meat mass was formulated as follow: $920 \mathrm{~g}$ of meat, $12 \mathrm{~g}$ of starch and $3.0 \mathrm{~g}$ of phosphates dissolved in $50 \mathrm{~mL}$ of water. Three different salt concentrations were used: $2 \%, 1.5 \%$ and $1 \%(\mathrm{w} / \mathrm{w}$, salt/base-meat mass). These formulations corresponded to the three control patties (control 2\%, 1.5\% and 1\%). RWPS, at $2 \% \mathrm{w} / \mathrm{w}$, was added to the three control patty base-meat masses. These formulations were labeled as RWPS patties. Furthermore, the study included patties with sulfite as a microbial stable control. Sulfite is relatively often applied as a preservative by different meat industries (Urtiaga et al., 2013). In this case, sodium metabisulfite was dissolved in water and then added to the mixture of the ingredients, to obtain a final concentration of $300 \mathrm{mg} \mathrm{SO}$ per $\mathrm{kg}$ of patty base meat-mass.

Two patties of 100 grams were packaged in a single polyethylene/ethylene vinyl alcohol/polystyrene tray (Sanviplast, Barcelona, Spain) using modified-atmosphere packaging (MAP). The trays were filled with a gas mixture $\left(70 \% \mathrm{O}_{2} / 30 \% \mathrm{CO}_{2}\right)$ using a gas mixer (WITT-Gasetechnik GmbH \& Co KG, Witten, Germany), and sealed using a 
polyvinylidene chloride/polyethylene film. Samples were stored at $4^{\circ} \mathrm{C}$ for up to 15 days. Three trays, containing two patties, of each type of patty were prepared for each sampling time $(0,4,8,12$ and 15 days). Furthermore, due to the inevitable variability of the meat, the study was performed in triplicate, it is said, all the above-mentioned experiments were repeated at three different moments, using different meat batches.

A complementary study was also conducted to evaluate the protective effect of RWPS in air-packaged samples. Beef patties with two different salt levels (2\% and 1\%) were prepared as previously described, and packaged in independent trays. Sampling was conducted at days 1, 4 and 6 of storage, and the study was performed in duplicate.

\subsection{Analysis}

The main composition of the patties was measured, as well as nutritional parameters of interest such as fiber, mineral contents and Folin index, were measured. Furthermore, the shelf-life of beef patties was assessed by the evaluation of the meat spoilage microorganisms, using the criteria established by Debevere (2006).

\subsection{Microbial analysis}

Samples from both patties in the same tray $(25 \mathrm{~g})$ were homogenized with 225 $\mathrm{mL}$ of buffered peptone water in a stomacher bag using a laboratory bender (Stomacher 400, Colworth, London, UK) and conventionally diluted. Total aerobic mesophilic bacteria (TAMB) and lactic acid bacteria (LAB) were evaluated on PCA and MRS plates, respectively. TAMB and LAB were enumerated after 72 hours of incubation at $30^{\circ} \mathrm{C}$. Lag phase and the potential maximum rate were also calculated, according to the model described by Baranyi \& Roberts (1994) with the Excel ad-in DMFit tool.

\subsection{Physicochemical analysis}

\subsubsection{Moisture, fat and protein}


Moisture, fat and protein contents were measured according to AOAC (2000) methods 950.46, 991.36 and 981.1, respectively. The moisture content was determined by the difference in the sample weight before and after drying at $105^{\circ} \mathrm{C}$ to constant weight. The fat content was evaluated by Soxhlet extraction using petroleum ether in a Buchi B-811 extraction system (Buchi, Switzerland). The protein content was determined using the Kjeldahl method with a conversion factor of 6.25 to convert nitrogen into protein values.

\subsubsection{Dietary fiber}

The total dietary fiber content was evaluated using the kit provided by Sigma (St Lois, USA), based on AOAC (2000), method 985.29.

\subsubsection{Ash and mineral content}

The ash and mineral contents of the samples were determined according to AOAC (2000) method 969.23. Samples were incinerated at $525^{\circ} \mathrm{C}$ in a furnace $(\mathrm{P}-$ Selecta, Barcelona Spain) and then solubilized in $\mathrm{HNO}_{3}(25 \%)$. Sodium and potassium contents were determined using a Flame Photometer 410 (Corning, UK), while calcium content was measured using a polarized Zeeman atomic absorption spectrophotometer Z-8200 (Hitachi, Japan).

\subsubsection{Folin Index}

One gram of beef patty was added to $15 \mathrm{~mL}$ of methanol/HCl (97:3). Extraction was carried out under continuous soaking for 24 hours. The resulting extract was centrifuged, filtered and brought to $25 \mathrm{~mL}$. Folin Index was determined according to Singleton \& Rossi (1965) and expressed as mg of gallic acid equivalent (GAE) per gram of patty. 


\subsection{5. $p H$ and water activity}

The $\mathrm{pH}$ was measured using a puncture electrode (Crison, Barcelona, Spain) in combination with a Crison $2001 \mathrm{pH}$ meter. Their water activity was measured using an AquaLab Cx-2 water activity-meter (Decagon Devices Inc., Pullman, Wash., U.S.A.).

\subsection{Statistical analysis}

Statistical analysis of the data was performed using StatGraphics ${ }^{\circledR}$ Centurion XVI (Statpoint Technologies, Inc., Warrenton, VA, USA). Fisher's least significant difference test was performed, in order to identify significant differences ( $p$-value $<$ 0.05 ) between different formulations and at different days of storage.

\section{RESULTS AND DISCUSSION}

The main composition of the different batches in this study was evaluated to control the quality and the homogeneity of all the batches. The mean values of its main composition parameters were: moisture $(67.5 \pm 1.8 \%)$, total protein $(16.7 \pm 0.9 \%)$ and total lipid content $(13.6 \pm 1.2 \%)$.

\subsection{Microbial stability}

\subsubsection{Effect on total aerobic mesophilic bacteria population}

Microbial spoilage is considered the main factor that limits the shelf-life of refrigerated meat products due to the modifications in their odor, taste and appearance. Microbial spoilage is even more relevant in beef patties, as grinding and mixing processes enhance the risk of contamination and reduce microbial stability (Gill et al., 1996). Early meat spoilage increases food losses, which is of relevance to the increasing worldwide scarcity of protein resources. Meat spoilage should therefore be controlled, in order to avoid meat losses and to maintain an efficient food production system. However, consumer expectations focus on healthier foods, without chemical 
additives, that are low in salt and with a reasonably long shelf-life (Devcich et al., 2007). Then, the present study proposes the use of an alternative natural seasoning to extend the shelf-life of beef patties, especially of those with low-salt content.

The microbial population in beef meat varies widely between batches according to different factors such as animal age, feed type and slaughterhouse conditions. The effect of these variations should be borne in mind, to assure the stability of meat products during their shelf-life, especially because the microbial quality of the incoming raw material is the most relevant factor in the shelf-life of the final product (Gill et al., 1996). Accordingly, this study was performed in triplicate, using three different batches of beef meat.

Initial levels of TAMB in each batch of patties ranged between 3.1 and $4.3 \operatorname{logs}$ CFU/g, and the highest value was observed in experiment 2 (Figure 3.1.). These results clearly showed the variability of beef meat between batches and corroborated the convenience of using real replicates (different batches), when testing the efficacy of new products against food spoilers.

The shelf-life of the beef patties was assessed by the evaluation of their TAMB and LAB counts, and according to Debevere (2006), $10^{7} \mathrm{CFU} / \mathrm{g}$ was considered the end of the shelf-life. Generally, all the patties under study showed different shelf-life stability in the three experiments (Figure 3.1.). The control patties with $2 \%$ salt reached the end of their shelf-life (7 logs CFU/g) after 8-to-14 days of storage, while the control patties with lower salt levels also showed lower stability. The results clearly show that lowering salt levels promotes TAMB growth and reduces the microbial stability of patties. The shelf-life was shortened by around 2 days in the case of patties with $1.5 \%$ salt and by around 3 days in patties with $1 \%$ of salt (Figure 3.1.). A similar decrease in the shelf-life (around 4 days) was observed in cooked meat products after $40 \%$ salt 
reduction (Devlieghere et al., 2009). The observed instability caused by salt reduction can be attributed to the increased amount of water available to the microorganisms in the meat products (Doyle \& Glass, 2010).

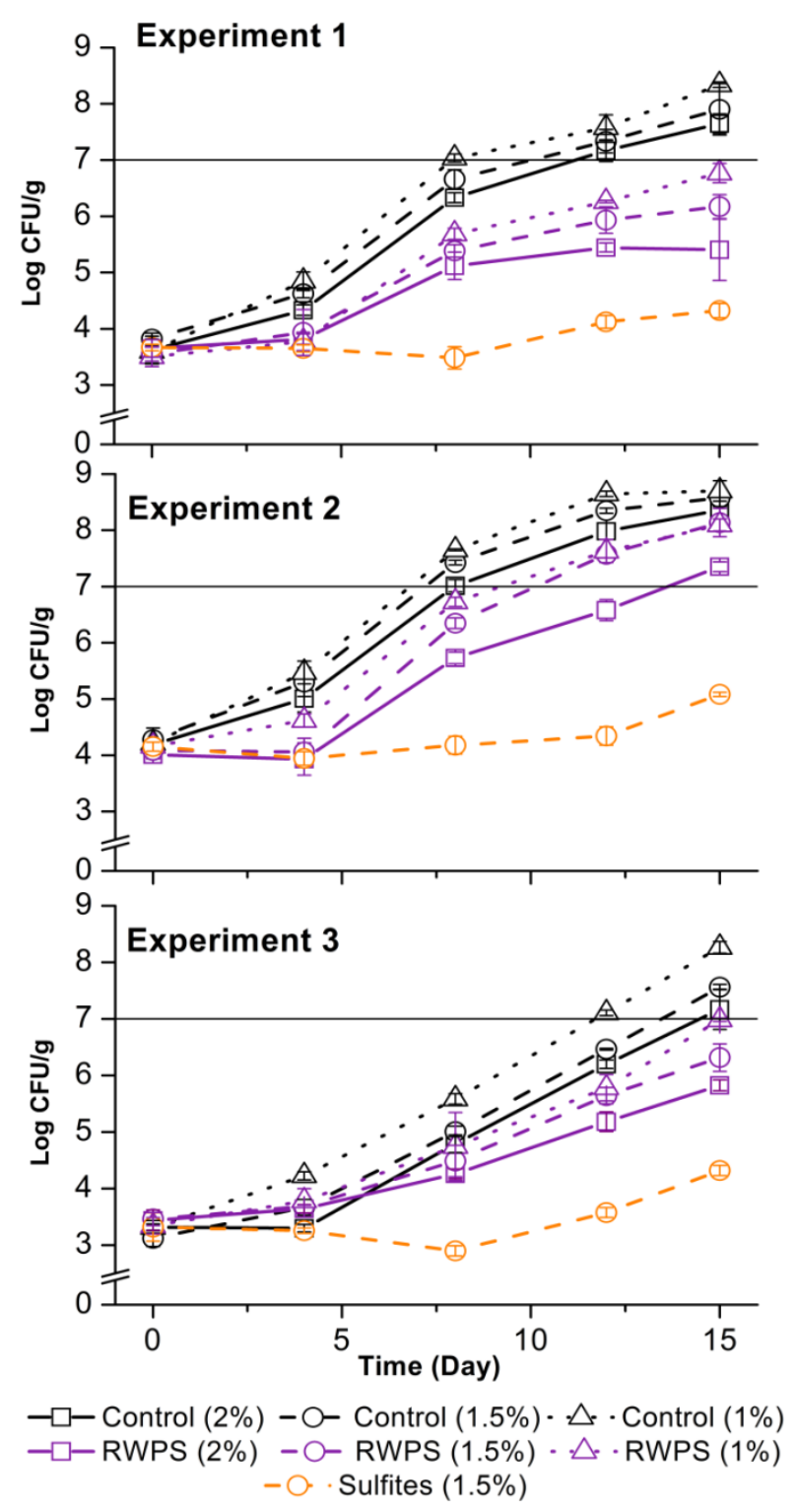

Figure 3.1. Total aerobic mesophilic bacteria (TAMB) counts (mean $\pm S D, n=3$ ) of beef patties without additives (Control), with sulfites (300 ppm $\mathrm{SO}_{2}$ ) and with $2 \%$ $(\mathrm{w} / \mathrm{w})$ of red wine pomace seasoning (RWPS), at three different salt levels $(2 \%, 1.5 \%$ and $1 \% \mathrm{w} / \mathrm{w}$ ), packaged in high-oxygen atmosphere and stored at $4^{\circ} \mathrm{C}$, for 15 days. Horizontal lines at $7 \operatorname{logs} \mathrm{CFU} / \mathrm{g}$ indicate the criteria established for the end of the shelf-life. 
The results also showed that the incorporation of RWPS counteracted the microbial instability of low-salt beef patties, and considerably increased their shelf-life (Figure 3.1.). Comparing RWPS patties with their respective control patties (at the same salt level) significantly lower TAMB counts were always observed in RWPS. This observation reveals the ability of RWPS to control microbial growth in different batches with different initial TAMB counts. Interestingly, RWPS patties with $1 \%$ salt showed a shelf-life similar or even longer than the shelf-life of the control samples with 2\% salt (Figure 3.1.).

The experimental data were fitted to the model proposed by Baranyi \& Roberts (1994) and the duration of the lag phase and the maximum growth rate were calculated. The use of the microbial growth models may provide a better understanding of the antimicrobial action of natural products (Jaiswal \& Jaiswal, 2015). The lag phase is a stationary phase during which the adaptation required for bacterial growth in the new medium takes place. It appears to be related to the preparation of bacteria for exponential growth and metal accumulation in the cell (Rolfe et al., 2012). An extended lag phase is desirable, to delay the onset of microbial growth and spoilage. Salt reduction shortened the duration of the lag phase (from 3.0 to 1.9 days) in the control patties. The incorporation of RWPS avoided the shortening in the lag phase produced by salt reduction. Interestingly, the lag phase of the RWPS patties with the lowest salt concentration was even longer $(3.8 \pm 0.3$ days $)$ than in the control samples with the highest level of salt. After adaptation to the new medium, the cells exponentially multiply reaching a potential maximum growth rate, until their growth is limited by nutrient availability. In agreement with previous results (Doyle \& Glass, 2010), the maximum specific growth rate was not significantly affected by the salt reduction applied in this study. Interestingly, RWPS increased salt susceptibility and decreased 
the maximum growth rate in samples with the highest level of salt (from 0.46 to 0.32 $\log (\mathrm{CFU} / \mathrm{g}) / \mathrm{day})$, revealing the ability of RWPS to slow down microbial growth. The aforementioned modifications of kinetic growth parameters highlight the importance of salt reduction and the benefits of using RWPS for the shelf-life of beef patties.

The extended shelf-life associated with RWPS, as well as the modifications observed in the kinetic growth parameters can be attributed to different and synergetic factors. The main factors appear to be the reductions in $\mathrm{pH}$, the phenolic content of RWPS, as well as the slight decrease in water activity.

The $\mathrm{pH}$ of the control patties was $5.89 \pm 0.04$, while the RWPS patties showed $\mathrm{pH}$ values of $5.45 \pm 0.04$. The reduction observed in their $\mathrm{pH}$ can mainly be explained by the presence of some organic acids, such as tartaric acid, in RWPS (Palma \& Barroso, 2002). The direct and positive effect of $\mathrm{pH}$ reduction on the microbial stability of food is well established. Furthermore, the organic acids present in RWPS may also induce structural changes and energy depletion in the microorganisms, contributing to the antimicrobial effect (Doores, 2005).

Salt has traditionally been used to decrease the water activity of meat products, inhibiting the growth of less halotolerant populations (Borch et al., 1996). This ability is due to its water retention capacity and its effect on protein solubility that increases the water holding capacity of meat products (Desmond, 2006). For these reasons, higher values of water activity were observed in low-salt beef patties (Table 3.1.). The incorporation of RWPS in the beef patty formulation produced a slight decrease in the water activity of the patties (Table 3.1.). This fact could be explained by their high content in fiber and potassium salts. RWPS patties presented $72 \%$ more fiber $(1.72 \pm$ $0.17 \%)$ than the control patties $(1.00 \pm 0.04 \%)$, due to the fiber present in RWPS 
(García-Lomillo et al., 2014). Plant fibers are known to possess excellent water retention capacities, due to the presence of polysaccharide chains that are able to hold relevant quantities of water through the formation of hydrogen bonds (Rodríguez et al., 2006).

Table 3.1. Water activity of beef patties prepared with and without red wine pomace seasoning (RWPS) at different salt levels. ${ }^{\text {a }}$

\begin{tabular}{cccc}
\hline & \% Salt $(w / w)$ & Control Patties & RWPS Patties \\
\hline Water & 2 & $0.979 \pm 0.001 \mathrm{ab}$ & $0.976 \pm 0.003 \mathrm{a}$ \\
Activity & 1.5 & $0.982 \pm 0.001 \mathrm{~cd}$ & $0.980 \pm 0.001 \mathrm{bc}$ \\
& 1 & $0.986 \pm 0.001 \mathrm{f}$ & $0.984 \pm 0.001 \mathrm{de}$ \\
\hline
\end{tabular}

${ }^{a}$ Different letters (a,b,c,d,e,f) denote significant differences (LSD test and p-value $\left.<0.05\right)$ between products. Values are means \pm standard deviation of three replicate determinations.

RWPS also increased the ash content of the beef patties, but the difference was only significant in low-salt patties (Table 3.2.). This observation is in accordance with its high mineral content, mainly potassium, with minor levels of sodium and calcium (García-Lomillo et al., 2014). Potassium is mainly found in the form of organic salt such as acetates, tartrates, oxalates and also at minor levels in inorganic forms such as sulfates or phosphates (Rogiers et al., 2006). The incorporation of these salts with the new seasoning can also contribute to the tendency towards lower water activity observed in the RWPS patties.

Apart from the effect caused by $\mathrm{pH}$ and water activity reductions, polyphenols also seem to play a relevant role in the observed antimicrobial activity. The RWPS patties showed higher Folin Index values $(0.942 \pm 0.036 \mathrm{mg}$ GAE /g meat $)$ than the control samples $(0.465 \pm 0.061 \mathrm{mg}$ GAE/g meat). The higher Folin Index can be attributed to the phenolic compounds present in the new seasoning (García-Lomillo et al., 2014). In recent years, there has been increasing interest in obtaining polyphenol- 
enriched extracts with antimicrobial activity from grape products. The capacity of grape skin extracts to inhibit the growth of Escherichia coli and Listeria innocua at concentrations ranging from $2 \%$ to $9 \%$ was noted by Tseng \& Zhao (2012). Grape pomace extracts (between $1 \%$ and $10 \%$ ) also reported an intense activity against spoilage populations in beef patties (Sagdic et al., 2011). However, this protective effect was not observed at lower levels of grape pomace extracts $(0.06 \%)$ (Garrido et al., 2011). Phenolic acids, especially gallic acid, appear to play a prevalent role in the antimicrobial effect of grape extracts (Cueva et al., 2012; Silván et al., 2013), although Cushnie \& Lamb (2005) also reported the importance of flavonoid compounds. Furthermore, it seems that the combination of phenolic compounds provides a synergic antimicrobial effect (Silván et al., 2013). The inhibitory mechanisms of phenolic compounds are related to nutrient chelation, microbial membrane disruption, and inhibition of intracellular material (Cowan, 1999).

Table 3.2. Ash, sodium, potassium contents and sodium-potassium ratio $(\mathrm{Na} / \mathrm{K}$ ratio) of beef patties prepared without (control) and with red wine pomace seasoning (RWPS). ${ }^{\text {a }}$

\begin{tabular}{lccccc}
\hline Sample & $\begin{array}{c}\text { \% Salt } \\
(\mathbf{w} / \mathbf{w})\end{array}$ & $\begin{array}{c}\text { Ash content } \\
(\mathbf{m g} / \mathbf{g})\end{array}$ & $\begin{array}{c}\text { Sodium content } \\
(\mathbf{m g} / \mathbf{g})\end{array}$ & $\begin{array}{c}\text { Potassium } \\
\text { content }(\mathbf{m g} / \mathbf{g})\end{array}$ & $\begin{array}{c}\mathbf{N a} / \mathrm{K} \\
\text { ratio }\end{array}$ \\
\hline & 2 & $30.2 \pm 0.06 \mathrm{a}$ & $7.44 \pm 0.21 \mathrm{a}$ & $2.87 \pm 0.04 \mathrm{~b}$ & 2.59 \\
$\begin{array}{c}\text { Control } \\
\text { patties }\end{array}$ & 1.5 & $24.8 \pm 0.06 \mathrm{~b}$ & $6.01 \pm 0.11 \mathrm{~b}$ & $2.89 \pm 0.09 \mathrm{~b}$ & 2.08 \\
& 1 & $19.5 \pm 0.17 \mathrm{~d}$ & $4.59 \pm 0.44 \mathrm{c}$ & $2.91 \pm 0.21 \mathrm{~b}$ & 1.58 \\
\hline & 2 & $30.2 \pm 0.28 \mathrm{a}$ & $7.61 \pm 0.22 \mathrm{a}$ & $3.62 \pm 0.23 \mathrm{a}$ & 2.10 \\
\hline $\begin{array}{l}\text { RWPS } \\
\text { patties }\end{array}$ & 1.5 & $26.1 \pm 0.15 \mathrm{~b}$ & $6.06 \pm 0.05 \mathrm{~b}$ & $3.52 \pm 0.11 \mathrm{a}$ & 1.72 \\
& 1 & $21.9 \pm 0.02 \mathrm{c}$ & $4.51 \pm 0.17 \mathrm{c}$ & $3.43 \pm 0.12 \mathrm{a}$ & 1.32 \\
\hline
\end{tabular}

${ }^{a}$ Different letters (a,b,c,d) denote significant differences (LSD test and p-value $<0.05$ ) between patties. Values are means \pm standard deviation of three replicate determinations.

The incorporation of sulfites strongly inhibited microbial growth and the samples did not reach $10^{5} \mathrm{CFU} / \mathrm{g}$ after 15 days of storage in any of the experiments 
(Figure 3.1.). TAMB was even reduced during the first 8 days exerting bactericidal effect, which can be attributed to sulfite reactivity to microbial protein structures, causing blockage of membrane transport, inhibition of glycolysis, nutrient destruction, and inhibition of microbial metabolism. Despite their excellent antimicrobial activities, sulfites have been related to adverse reactions, especially among sulfite sensitive consumers (Cornelius \& Lilian, 2005). Moreover, the U. S. Food and Drug Administration does not allow the use of sulfites in meat products, because it destroys thiamin and reduces the nutritional value of meat. Consequently, the seasoning under study can be an excellent alternative to assure a satisfactory shelf-life of meat products without using allergenic additives that are prohibited in some countries.

\subsubsection{Effect on lactic acid bacteria population}

$\mathrm{LAB}$ are very resistant to inhibition by $\mathrm{CO}_{2}$ and easily dominate the microbial population in meats stored in MAP atmospheres (Schillinger et al., 2006). Sensory modifications caused by LAB include sour and acid off-odors and off-flavors related to the formation of lactic acid, acetic acid and sulfur compounds as well as gas and slime production (Borch et al., 1996; Schillinger et al., 2006). Those deteriorations are detectable by consumers when LAB counts reach $10^{7} \mathrm{CFU} / \mathrm{g}$.

The results showed that TAMB and LAB counts presented similar magnitudes. This fact seems to indicate the predominant role of LAB in MAP-stored meat products (Figure 3.2.). As in the case of TAMB counts, initial LAB counts varied between batches from 2.3 to $3.8 \operatorname{logs} \mathrm{CFU} / \mathrm{g}$ (Figure 3.2.). Different growth patterns were also observed between experiments and consequently the shelf-life of the patties was variable. 


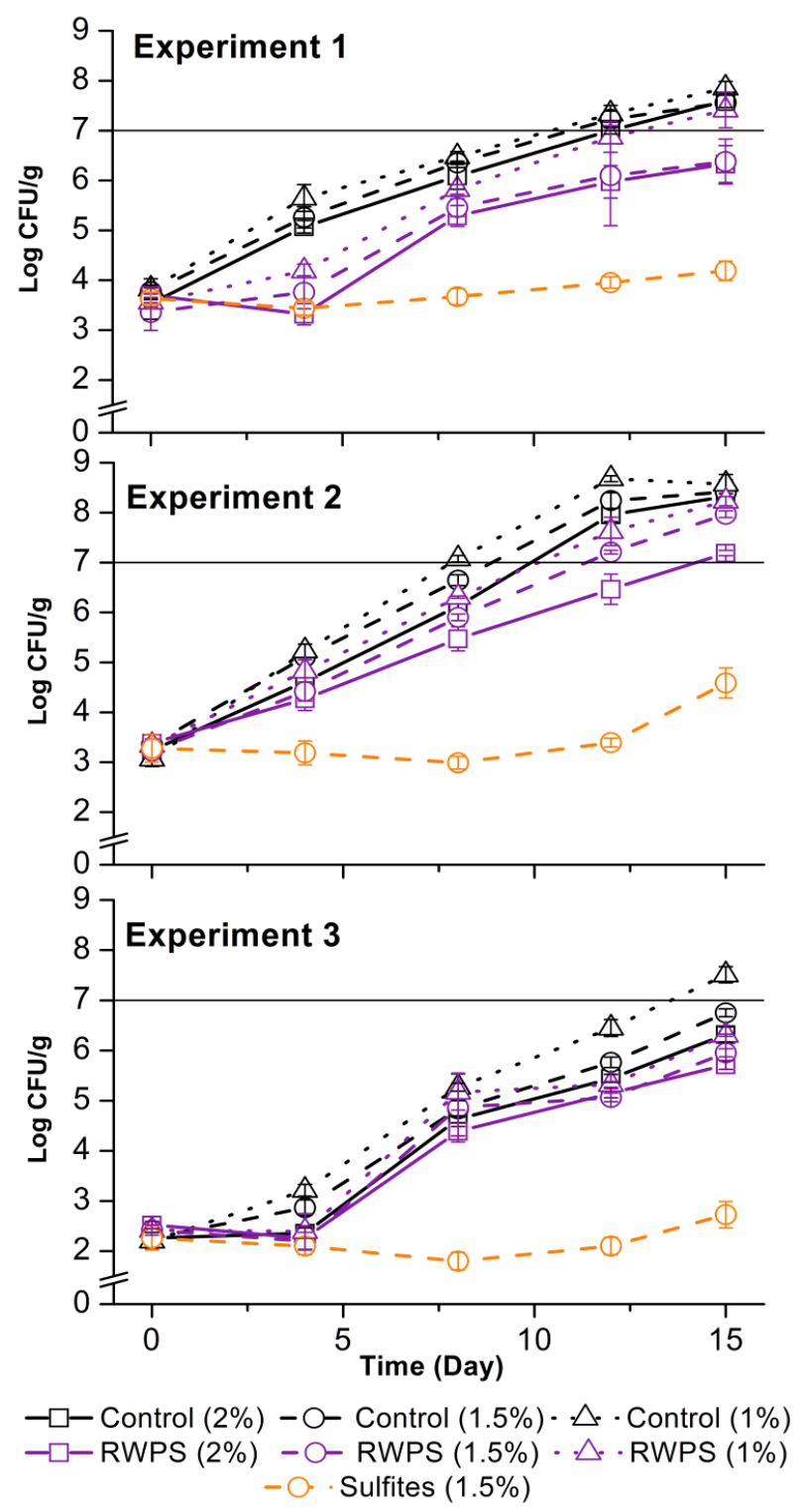

Figure 3.2. Lactic acid bacteria $(\mathrm{LAB})$ counts (mean $\pm \mathrm{SD}, \mathrm{n}=3$ ) of beef patties without additives (Control), with sulfites $\left(300 \mathrm{ppm} \mathrm{SO}_{2}\right)$ and with $2 \%(\mathrm{w} / \mathrm{w})$ of red wine pomace seasoning (RWPS), at three different salt levels (2\%, $1.5 \%$ and $1 \% \mathrm{w} / \mathrm{w})$, packaged in high-oxygen atmosphere and stored at $4^{\circ} \mathrm{C}$, for 15 days. Horizontal lines at 7 logs CFU/g indicate the criteria established for the end of the shelf-life.

Control patties with $2 \%$ salt showed shelf-lives that ranged between 10 and 15 days. The patties with reduced salt levels showed accelerated LAB growth and shorter shelf-lives ( 2 days). RWPS delayed LAB growth and improved the stability of patties, especially in the case of patties with the lowest-salt levels. These results revealed the ability of the seasoning to delay LAB growth in beef patties and to counteract the 
microbial instability caused by salt reduction. Furthermore, the RWPS patties with $2 \%$ salt were very stable and none reached $10^{7} \mathrm{CFU} / \mathrm{g}$ in any of the experiments after 15 days of storage. These results could be explained by the synergic antimicrobial action of salt and polyphenols (Cueva et al., 2012; Juneja et al., 2013).

The growth of $\mathrm{LAB}$ is delayed in mediums with low $\mathrm{pH}$ and water activity (Schillinger et al., 2006). Therefore, the reduction in $\mathrm{pH}$ and water activity caused by RWPS may contribute to its effect as a LAB inhibitor. Polyphenol content may also play a key role in delaying LAB growth in RWPS patties. Phenols present in grape products have been reported to inhibit LAB populations, although this effect seems to depend on the polyphenol type, concentration, growth medium and the type of LAB. Grape pomace extracts exerted an intense antimicrobial activity against the growth of Streptococcus thermophiles, Lactobacillus fermentum and Lactobacillus acidophilus, lowering LAB counts and their growth rates (Tabasco et al., 2011). However, the same study revealed that some Lactobacillus plantarum, Lactobacillus casei, and Lactobacillus bulgaricus strains are able to metabolize phenolic compounds and reached higher final counts in the presence of grape polyphenols.

As in the case of TAMB, the use of sulfites strongly inhibited LAB growth and the LAB population did not reach $10^{5} \mathrm{CFU} / \mathrm{g}$ in any of the experiments. The inhibitor effect of sulfite on LAB populations is well known, for which reason it is one of the most commonly used products, among others, to control fermentation processes in the alcoholic beverage industry (Cornelius \& Lilian, 2005).

\subsubsection{Effect in patties under air packaging conditions}

The behavior of spoilage populations and the spoilage pattern of meat products strongly depend on the packaging conditions (Borch et al., 1996). Consequently, a 
complementary study was conducted to evaluate the preservative efficacy of RWPS against microbial populations in air-packaged beef patties.

The shelf-life of air-packaged patties was shorter than in MAP, most likely due to the absence of $\mathrm{CO}_{2}$ (Figure 3.3.). Control patties with $2 \%$ and $1 \%$ salt reached $10^{7}$ CFU/g after 5 and 3 days of storage, respectively. As in the case of MAP experiments, RWPS improved the microbial stability of the samples. RWPS incorporation delayed the end of shelf-life to 6 and 4 days in the patties with $2 \%$ and $1 \%$ of salt, respectively. With regard to patties containing sulfites, they were very stable with no significant growth through storage.

In summary, the microbial results showed that RWPS was able to extended shelf-life of normal and low-salt patties, although the preservative potential of RWPS is lower than other chemical additives such as sulfites. These results may benefit consumers and retailers, reduce food losses and improve the efficacy of the meat supply chain, using synthetic additives in lower quantities or without using them.

\subsection{Effect of RWPS on beef patty composition}

In addition to the antimicrobial effects described above, the incorporation of RWPS in patties improved their composition, which can improve the consumer perception of the meat products, through the addition of some "nutritional or functional" values. The use of the proposed seasoning enhanced the level of potassium (around 23\%) and reduced the $\mathrm{Na} / \mathrm{K}$ ratio of the patties (Table 3.2.). Comprehensive sodium reduction, alone and in combination with increasing intakes of potassium or calcium, has been reported to produce substantial reductions in blood pressure, which is linked to lower mortality rates due to strokes and coronary heart disease (Doyle \& Glass, 2010; Perez \& Chang, 2014). In this regard, the Na/K ratio correlates better with 
blood pressure than using sodium or potassium levels alone (Perez \& Chang, 2014). Interestingly, RWPS patties also showed higher values of calcium than control samples, from $56 \mathrm{ppm}$ to $80 \mathrm{ppm}$.
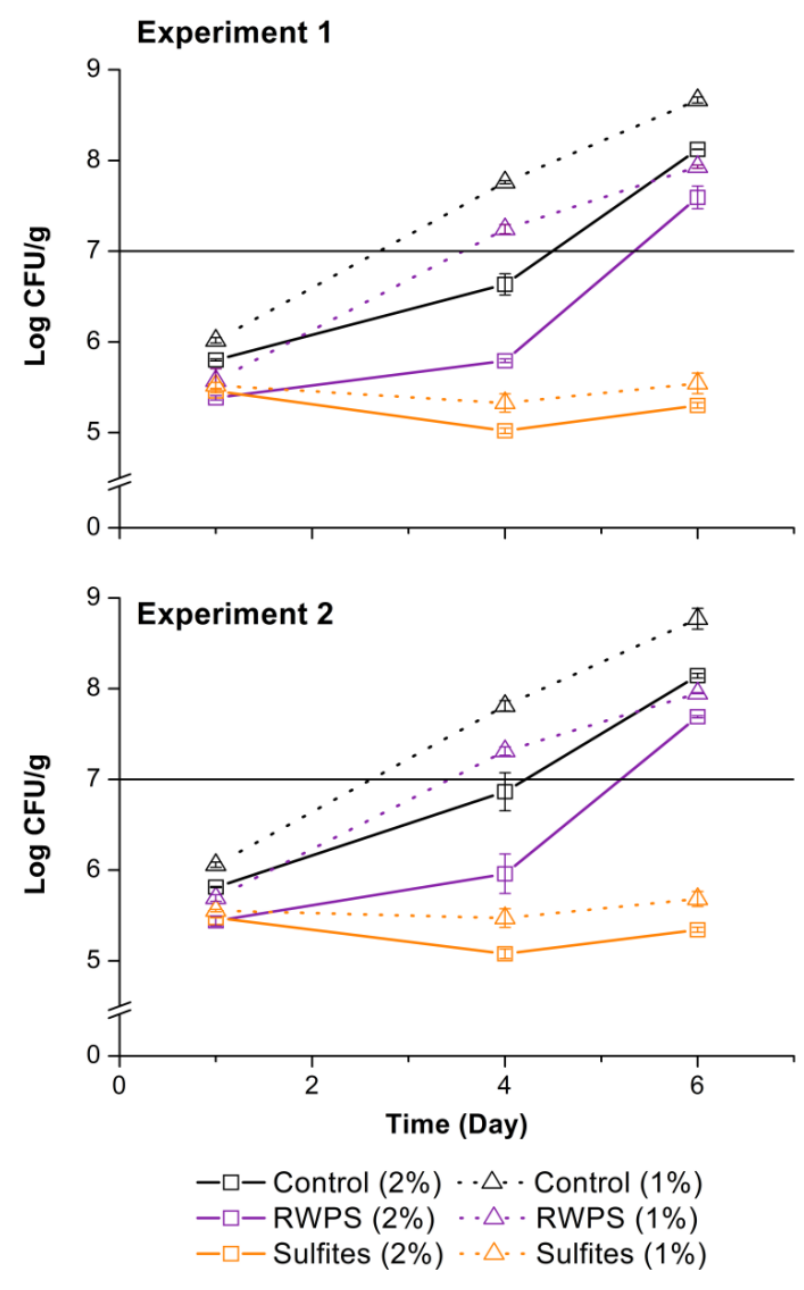

Figure 3.3. Total aerobic mesophilic bacteria (TAMB) counts (mean $\pm S D, n=3$ ) of air-packaged beef patties without additives (Control), with sulfites $\left(300 \mathrm{ppm} \mathrm{SO}_{2}\right)$ or with $2 \%(\mathrm{w} / \mathrm{w})$ of red wine pomace seasoning (RWPS), at two different salt levels (2\%, and $1 \% \mathrm{w} / \mathrm{w}$ ) stored at $4{ }^{\circ} \mathrm{C}$ for 6 days. Horizontal lines at $7 \mathrm{logs} \mathrm{CFU} / \mathrm{g}$ indicate the criteria established for the end of the shelf-life.

Furthermore, the dietary fiber and antioxidant contribution of RWPS could be of interest, to improve the intake of these nutrients in societies where consumption of vegetal foods may be low (Decker \& Park, 2010). As meat and meat products are widely consumed in these populations, they have been proposed as functional foods to 
be fortified with those nutrients (Decker \& Park, 2010). For example, $100 \mathrm{~g}$ of RWPS patties supplied $7 \%$ of the recommended dietary fiber intake of $25 \mathrm{~g} / \mathrm{day}$. Furthermore, from a commercial point of view, "high in fiber" claims are very positively valued among consumers and increase the consumer perceived value of the final product (Morley, 2013). This positive effect of fiber may either be enhanced or be synergic with the positive antioxidant effect of RWPS phenolic compounds. Numerous studies indicate certain well-established health effects of grapes and grape-related products, for example, on cardiovascular disease risk (Yu \& Ahmedna, 2013).

\section{CONCLUSIONS}

In conclusion, the use of $2 \%$ RWPS enabled the reduction of 0.5 and $1 \mathrm{~g}$ of salt by each $100 \mathrm{~g}$ of patty without compromising their microbial stability. RWPS delayed TAMB and LAB growth in low-salt beef patties stored under MAP and air packaging. Moreover, RWPS notably increased the stability of normal patties ( $2 \%$ salt), avoiding the use of allergenic preservatives as sulfites. Furthermore, the RWPS patties provided a relevant content of fiber and antioxidants (mainly phenolic compounds), together with relevant amounts of potassium and calcium as well as low sodium levels, producing meat products with lower $\mathrm{Na} / \mathrm{K}$ ratios.

\section{REFERENCES}

AOAC. (2000). Official methods of analysis of AOAC International. Gaithersburg, Md.: AOAC International.

Baranyi, J., \& Roberts, T. A. (1994). A dynamic approach to predicting bacterial growth in food. International Journal of Food Microbiology, 23(3), 277-294.

Borch, E., Kant-Muermans, M.-L., \& Blixt, Y. (1996). Bacterial spoilage of meat and cured meat products. International Journal of Food Microbiology, 33(1), 103120.

Cornelius, S. O., \& Lilian, W. (2005). Sulfur Dioxide and Sulfites. Antimicrobials in Food, Third Edition, (pp. 143-167): CRC Press.

Cowan, M. M. (1999). Plant Products as Antimicrobial Agents. Clinical Microbiology Reviews, 12(4), 564-582. 
Cueva, C., Mingo, S., Muñoz-González, I., Bustos, I., Requena, T., del Campo, R., Martín-Álvarez, P. J., Bartolomé, B., \& Moreno-Arribas, M. V. (2012). Antibacterial activity of wine phenolic compounds and oenological extracts against potential respiratory pathogens. Letters in Applied Microbiology, 54(6), 557-563.

Cushnie, T. P. T., \& Lamb, A. J. (2005). Antimicrobial activity of flavonoids. International Journal of Antimicrobial Agents, 26(5), 343-356.

Debevere, J. (2006). Microbial Guide Values \& Legal Microbiological Criteria. University of Gent.

Decker, E. A., \& Park, Y. (2010). Healthier meat products as functional foods. Meat Science, 86(1), 49-55.

Del Pino-García, R., García-Lomillo, J., Rivero-Perez, M. D., González-Sanjosé, M. L., \& Muñiz, P. (2015). Adaptation and Validation of QUick, Easy, New, CHEap, and Reproducible (QUENCHER) Antioxidant Capacity Assays in Model Products obtained from Residual Wine Pomace. Journal of Agricultural and Food Chemistry.

Desmond, E. (2006). Reducing salt: A challenge for the meat industry. Meat Science, 74(1), 188-196.

Devcich, D. A., Pedersen, I. K., \& Petrie, K. J. (2007). You eat what you are: Modern health worries and the acceptance of natural and synthetic additives in functional foods. Appetite, 48(3), 333-337.

Devlieghere, F., Vermeiren, L., Bontenbal, E., Lamers, P.-P., \& Debevere, J. (2009). Reducing salt intake from meat products by combined use of lactate and diacetate salts without affecting microbial stability. International Journal of Food Science and Technology, 44(2), 337-341.

Doores, S. (2005). Organic Acids. Antimicrobials in Food, Third Edition, (pp. 91142): CRC Press.

Doyle, M. E., \& Glass, K. A. (2010). Sodium Reduction and Its Effect on Food Safety, Food Quality, and Human Health. Comprehensive Reviews in Food Science and Food Safety, 9(1), 44-56.

EuropeanComission. (2012). Survey on Members States' Implementation of the EU Salt Reduction. Framework

García-Lomillo, J., González-SanJosé, M. L., Del Pino-García, R., Rivero-Pérez, M. D., \& Muñiz-Rodríguez, P. (2014). Antioxidant and antimicrobial properties of wine byproducts and their potential uses in the food industry. Journal of Agricultural and Food Chemistry, 62(52), 12595-12602.

Garrido, M. D., Auqui, M., Martí, N., \& Linares, M. B. (2011). Effect of two different red grape pomace extracts obtained under different extraction systems on meat quality of pork burgers. LWT - Food Science and Technology, 44(10), 22382243.

Gill, C. O., McGinnis, J. C., Rahn, K., \& Houde, A. (1996). The hygienic condition of manufacturing beef destined for the manufacture of hamburger patties. Food Microbiology, 13(5), 391-396. 
González San José, M. L., García Lomillo, J., Del Pino García, R., Dolores Rivero, M., \& Muñiz Rodríguez, P. (2015). Sazonador de origen vegetal con propiedades conservantes, sustitutivo de la sal, y procedimiento de obtención del mismo. ES2524870 B2. Spain.

Hotchkiss, S. (2012). Edible seaweeds: A rich source of flavour components for sodium replacement. Agro Food Industry Hi-Tech, 23(6), 30-32.

Jaiswal, A. K., \& Jaiswal, S. (2015). 12 - Modelling the effects of natural antimicrobials as food preservatives. T. M. Taylor (Ed.), Handbook of Natural Antimicrobials for Food Safety and Quality, (pp. 259-284). Oxford: Woodhead Publishing.

Juneja, V. K., Altuntaş, E. G., Ayhan, K., Hwang, C.-A., Sheen, S., \& Friedman, M. (2013). Predictive model for the reduction of heat resistance of Listeria monocytogenes in ground beef by the combined effect of sodium chloride and apple polyphenols. International Journal of Food Microbiology, 164(1), 54-59.

Minasian, S. (2011). Permeate can help you reduce sodium while improving flavor. Dairy Pipeline, 23(2), 3-8.

Morley, W. (2013). The challenges for natural ingredients in foods - Fat, salt, sugar and air! Food Science and Technology (London), 27(1), 17-20.

Palma, M., \& Barroso, C. G. (2002). Ultrasound-assisted extraction and determination of tartaric and malic acids from grapes and winemaking by-products. Analytica Chimica Acta, 458(1), 119-130.

Perez, V., \& Chang, E. T. (2014). Sodium-to-Potassium Ratio and Blood Pressure, Hypertension, and Related Factors. Advances in Nutrition: An International Review Journal, 5(6), 712-741.

Rodríguez, R., Jiménez, A., Fernández-Bolaños, J., Guillén, R., \& Heredia, A. (2006). Dietary fibre from vegetable products as source of functional ingredients. Trends in Food Science \& Technology, 17(1), 3-15.

Rogiers, S. Y., Greer, D. H., Hatfield, J. M., Orchard, B. A., \& Keller, M. (2006). Mineral sinks within ripening grape berries (Vitis vinifera L.). Vitis - Journal of Grapevine Research, 45(3), 115-123.

Rolfe, M. D., Rice, C. J., Lucchini, S., Pin, C., Thompson, A., Cameron, A. D. S., Alston, M., Stringer, M. F., Betts, R. P., Baranyi, J., Peck, M. W., \& Hinton, J. C. D. (2012). Lag Phase Is a Distinct Growth Phase That Prepares Bacteria for Exponential Growth and Involves Transient Metal Accumulation. Journal of Bacteriology, 194(3), 686-701.

Sagdic, O., Ozturk, I., Yilmaz, M. T., \& Yetim, H. (2011). Effect of Grape Pomace Extracts Obtained from Different Grape Varieties on Microbial Quality of Beef Patty. Journal of Food Science, 76(7), M515-M521.

Schillinger, U., Holzapfel, W. H., \& Björkroth, K. J. (2006). Lactic acid bacteria. C. d. W. Blackburn (Ed.), Food Spoilage Microorganisms, (pp. 541-578). Cambridge, England: Woodhead Publishing Limited. 
Silván, J. M., Mingo, E., Hidalgo, M., de Pascual-Teresa, S., Carrascosa, A. V., \& Martinez-Rodriguez, A. J. (2013). Antibacterial activity of a grape seed extract and its fractions against Campylobacter spp. Food Control, 29(1), 25-31.

Singleton, V. L., \& Rossi, J. A., Jr. (1965). Colorimetry of Total Phenolics with Phosphomolybdic-Phosphotungstic Acid Reagents. American Journal of Enology and Viticulture, 16(3), 144-158.

Tabasco, R., Sánchez-Patán, F., Monagas, M., Bartolomé, B., Victoria Moreno-Arribas, M., Peláez, C., \& Requena, T. (2011). Effect of grape polyphenols on lactic acid bacteria and bifidobacteria growth: Resistance and metabolism. Food Microbiology, 28(7), 1345-1352.

Tseng, A., \& Zhao, Y. (2012). Effect of Different Drying Methods and Storage Time on the Retention of Bioactive Compounds and Antibacterial Activity of Wine Grape Pomace (Pinot Noir and Merlot). Journal of Food Science, 77(9), H192H201.

Urtiaga, C., Amiano, P., Azpiri, M., Alonso, A., \& Dorronsoro, M. (2013). Estimate of dietary exposure to sulphites in child and adult populations in the Basque Country. Food Additives and Contaminants - Part A Chemistry, Analysis, Control, Exposure and Risk Assessment, 30(12), 2035-2042.

Viuda-Martos, M., Ruiz-Navajas, Y., Fernández-López, J., \& Pérez-Álvarez, J. A. (2011). Spices as functional foods. Critical Reviews in Food Science and Nutrition, 51(1), 13-28.

Yang, H., Han, M., Bai, Y., Han, Y., Xu, X., \& Zhou, G. (2015). High pressure processing alters water distribution enabling the production of reduced-fat and reduced-salt pork sausages. Meat Science, 102, 69-78.

Yu, J., \& Ahmedna, M. (2013). Functional components of grape pomace: their composition, biological properties and potential applications. International Journal of Food Science \& Technology, 48(2), 221-237. 


\section{CHAPTER 4:}

A New Seasoning with Potential Effect Against Foodborne Pathogens 



\section{Presentación}

La seguridad de los alimentos puede verse comprometida por el crecimiento de microorganismos patógenos. El uso de ingredientes que inhiban o limiten el crecimiento de estos microorganismos permite reducir el riesgo de toxiinfección alimentaria aumentando la seguridad alimentaria.

La capacidad antimicrobiana frente a microorganismos alternantes exhibida por el sazonador derivado del orujo libre de pepitas, descrita en el capítulo anterior, impulsó el estudio que se presenta en este capítulo y que se centra en la evaluación de la actividad antimicrobiana frente a microorganismos patógenos. Se seleccionaron 3 microorganismos con gran incidencia en la industria alimentaria: Staphylococcus aureus, Listeria innocua y dos cepas diferentes de Escherichia coli, evaluándose el efecto del sazonador a dos concentraciones, $2 \%$ que había sido exitosa en los estudios anteriores y el $4 \%$ que también podría ser aplicada en caso necesario sin grandes limitaciones.

\section{Resultados más relevantes}

El sazonador mostró nuevamente actividad microbiana pero variable según especie y cepa. Fue bactericida al $4 \%$ frente a $S$. aureus, pero sólo bacteriostático frente a L.innocua y E. coli, efecto observado también al $2 \%$ aunque en menor intensidad.

La actividad antimicrobiana observada puede adscribirse a la acción de los fenoles presentes en el sazonador, y en menor medida por la reducción del pH causada por el sazonador. 



\title{
Chapter 4: A New Seasoning with Potential Effect Against
}

\section{Foodborne Pathogens}

\begin{abstract}
The food industry is constantly looking for natural alternatives to chemical additives. Recently, natural seasonings (RWPS) with flavoring, antioxidant and antimicrobial activities have been obtained from red wine pomace. This study focused on the antimicrobial activity of RWPS against three microorganisms: Staphylococcus aureus, Listeria innocua, and Escherichia coli. Two different concentrations of the studied seasoning were assayed: $40 \mathrm{~g} / \mathrm{L}$ that was used in different food applications and $20 \mathrm{~g} / \mathrm{L}$ that was known to be active against food spoilage microorganisms. RWPS (at $40 \mathrm{~g} / \mathrm{L}$ ) presented bactericidal effects against $S$. aureus and L. innocua. Bacteriostatic effects were observed against two strains of $E$. coli with RWPS at $40 \mathrm{~g} / \mathrm{L}$ and against $S$. aureus with RWPS at $20 \mathrm{~g} / \mathrm{L}$. Furthermore, RWPS at $40 \mathrm{~g} / \mathrm{L}$ also slowed the growth of E. coli and L. innocua, extending the duration of the lag phase and decreasing the maximum growth rate of these two microorganisms. In conclusion, the studied seasoning, at the concentrations in which it was satisfactorily applied in food, inhibits reasonably the growth of the studied foodborne pathogens.
\end{abstract}
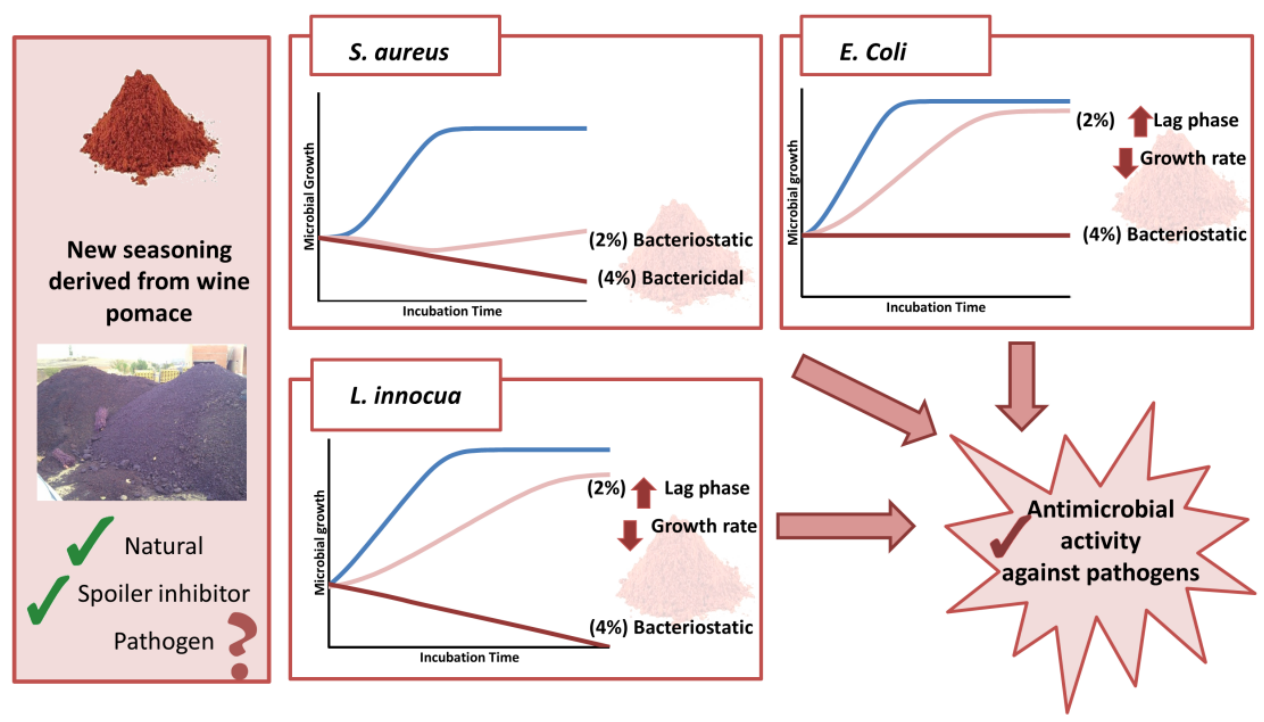


\section{INTRODUCTION}

Foodborne pathogens cause more than 320,000 cases of human infection each year in the European Union (EFSA \& ECDC, 2015). They are produced by the consumption of food and water contaminated with pathogenic microorganisms and their toxins. Eggs, meat and fish products are the most susceptible categories to pathogenic outbreaks (EFSA \& ECDC, 2015). Therefore, the food industry needs to find acceptable solutions to assure the safety of their products. Artificial additives are widely applied to control the growth of foodborne pathogenic (Davidson \& Branen, 2005). However, the rejection of chemical additives by consumers has led the food industry to seek other alternatives. Different natural products with a high potential to inhibit microbial growth, such as spices and products derived from agricultural byproducts, have been proposed to extend the shelf-life of food products (Grohs \& Kunz, 2000; Souza et al., 2005). In this sense, natural seasonings with effective preservative capacity have been recently obtained from red wine pomace (García-Lomillo et al., 2014; González San José et al., 2015). Wine pomace is a by-product of winemaking process consisting in the solid parts of grape pomace separated after fermentation. Currently, its applications are very limited and it is generally used to obtain steam distilled spirits or directly disposed to landfill without economic benefits. The patented process to obtain these natural seasoning enables the reutilization of an agricultural byproduct by using only sustainable techniques (González San José et al., 2015). These seasonings showed satisfactory antimicrobial effects against total aerobic mesophilic bacteria, lactic acid bacteria and Enterobacteriaceae in beef homogenates. This activity was ascribed to their high content in extractable total phenolic compounds including catechins, anthocyanins and proanthocyanidins (García-Lomillo et al., 2014). Furthermore, the seasonings reported excellent properties to be used as food ingredients 
as well as high levels of fiber, protein and minerals, mainly potassium with low level of sodium (García-Lomillo et al., 2014). Consumer studies also indicated the suitability of RWPS to be included in different food systems as hamburgers and salty snacks (data for publishing).

Listeriosis is the primary cause of death by foodborne pathogens due to its very high mortality rate $(15.6 \%)$. A relatively large number $(1,763)$ of confirmed cases of listeriosis occurred in the European Union (EFSA \& ECDC, 2015). Listeriosis is linked to the presence of Listeria monocytogenes, a Gram-positive bacterium, in smoked fish, cheeses and ready-to-eat meat products. People with weakened immune systems such as older adults and pregnant women represent the groups at highest risk (EFSA \& ECDC, 2015).

Escherichia coli is a common Gram-negative bacterium in the human gastrointestinal tract that forms part of the "normal" bacterial flora. Nevertheless, some E. coli may also be pathogenic and cause urinary tract infections, diarrhea, respiratory problems, and other illnesses (Banatvala et al., 2001). The development of diarrhea is usually associated with the consumption of food (mainly meat products) or water contaminated with faeces from infected animals and poor hygiene and food handling practices. Different strains may present diverse mechanisms to avoid the effect of antimicrobials (Harris et al., 1979) and relevant differences have been observed in the behavior of different E. coli strains (Vaquero et al., 2007), underlining the need to evaluate the effects of antimicrobials on different strains.

Another common cause of bacterial food poisoning is staphylococcal intoxication, which is caused by the presence of heat stable enterotoxins produced by many strains of Staphylococcus aureus, after reaching > 5 Logs (CFU/g) (Le Loir et al., 
2003). S. aureus, a Gram-positive bacterium, is a poor competitor, but it is an ubiquitous microorganism and survives well in food factory environments. Staphylococcus sp. causes almost 300 foodborne outbreaks in a wide range of foods such as cheese, meat, and bakery products, every year (EFSA, 2009). Patients typically experience vomiting, stomach cramps, nausea, and diarrhea, and in severe cases, collapse (Le Loir et al., 2003).

The antimicrobial effect of natural ingredients is usually tested using endpoint methods such as agar diffusion and broth dilution (López-Malo Vigil et al., 2005). Agar well diffusion tests provide interesting information on the antimicrobial activity and permit comparisons between antimicrobials under the same conditions. However, these methods only provide qualitative results with sometimes contradictory conclusions (Rhodes et al., 2006; Xu et al., 2014). Another option is to determine minimum bactericidal concentration and minimum inhibitory concentration (MIC) by consecutive dilutions. These methods are also end-point methods and do not provide any information on the growth kinetic parameters or the effect of concentrations below the MIC (Jaiswal \& Jaiswal, 2015). To obtain safe food products, the complete microbial inactivation may not be required, being enough to maintain populations at low levels (López-Malo Vigil et al., 2005). Consequently, the assessment of growth and inactivation curves is of paramount importance, in order to obtain more detailed and accurate information. Different kinetic growth models, both empirical and mechanistic, have been successfully applied to describe the inhibition exerted by natural compounds (Gupta et al., 2012; Jaiswal \& Jaiswal, 2015). Modified Gompertz and Logistic models are empirical sigmoidal models that simply describe experimental data under certain conditions. In contrast, semi-mechanistic models, such as the Baranyi-Roberts model, 
are based on theoretical principles and are usually preferred over empirical methods because they are simpler and more sensible (Pérez-Rodríguez \& Valero, 2013).

In view of the above, this study examines the antimicrobial potential of a new seasoning derived from wine pomace against three microorganisms (Listeria innocua, E. coli and S. aureus), also evaluating its inhibitory effect by using kinetic models.

\section{MATERIALS AND METHODS}

\subsection{Material}

Red wine pomace seasoning (RWPS) was obtained using the process patented by González San José et al. (2015) at the pilot plant of the Food Technology Area (University of Burgos). The seasoning used in the present work was obtained from seedless wine pomace, and it is a powdered product free of microorganisms with a particle size of $<250 \mu \mathrm{m}$. The main composition of this seasoning (main components, minerals, fiber and extractable phenolic contents), as well as its antioxidant capacity and its capacity to inhibit spoilage microorganisms were described in a previous work (García-Lomillo et al., 2014).

\subsection{Growth medium preparation}

Tryptic soy broth (TSB) (Oxoid, Basingstoke, UK) supplemented with yeast extract (Oxoid) $(6 \mathrm{~g} / \mathrm{L})$ was used in the present study. Broths containing 20 and $40 \mathrm{~g} / \mathrm{L}$ of RWPS were also prepared and their $\mathrm{pH}$ and water activity were measured using a Crison 2001 pH meter and an AquaLab Cx-2 water activity-meter (Decagon Devices Inc., Pullman, Wash., U.S.A). Furthermore, Folin Index and Index Total Polyphenols (ITP) were measured according to the classical Folin-Ciocalteu reaction (Singleton \& Rossi, 1965) and by measuring the absorbance to $280 \mathrm{~nm}$, respectively (RibereauGayón et al., 1982). Controls at the same pH as broths with RWPS were also prepared 
by adjusting their $\mathrm{pH}$ with tartaric acid, in order to evaluate the contribution of $\mathrm{pH}$ reduction on the antimicrobial effect.

\subsection{Microbial culture}

Strains were obtained from the Spanish Type Culture Collection (CECT) and were reconstituted according to CECT recommendations. Four strains were used in the present study: E. coli CECT 434 (ATCC 25922) and CECT 504, L. innocua CECT 910 (ATCC 33090) and S. aureus CECT 435 (ATCC 25923). These microorganisms were selected based on their relevance to the food industry as previously described.

\subsection{Microbial growth tests}

Bacterial strains, taken from overnight samples, were aseptically inoculated in TBS broths at the different pHs and in the broths with the studied seasoning (at 20 and $40 \mathrm{~g} / \mathrm{L})$. Optical density measurements were used for convenient dilution of the inoculum to reach an initial level of $3 \mathrm{Logs}(\mathrm{CFU} / \mathrm{mL})$ using a SmartSpec Plus spectrophotometer (Biorad, Hercules, CA, USA). Broths were then incubated at $37^{\circ} \mathrm{C}$ and sampled at 1, 3, 5, 7, 9, 11, 24 and 34 hours. Samples were decimally diluted in peptone water (Merck, Darmstadt, Germany) and counted on pouring plates using tryptic soy agar (Oxoid) supplemented with yeast extract $(6 \mathrm{~g} / \mathrm{L})$, and incubated at $37^{\circ} \mathrm{C}$ for 24 hours. The experiments were conducted in triplicate, on three different days, using three different batches of the seasoning.

\subsection{Growth kinetic parameters}

Inhibition provided by RWPS was characterized using three primary growth models, which were used to fit the experimental data. The online tool DMFit, available at http://www.combase.cc, was used to obtain lag time $(\lambda)$, and maximum specific growth rate $(\mu)$, according to the equation proposed by Baranyi and Roberts (1994). 
The modified Gompertz model proposed by Gibson et al. (1987) was also applied. Data were fitted to equation 1, as proposed by the above authors.

$$
\mathrm{Nt}=\mathrm{A}+\mathrm{C} * \exp [-\exp (-\mathrm{B} *(\mathrm{t}-\mathrm{M}))](\text { eq. } 1)
$$

The logistic model was also fitted, according to equation 2 proposed by Gibson et al. (1987) (equation 2)

$$
\mathrm{Nt}=\mathrm{A}+\mathrm{C} /[1+\exp (-\mathrm{B} *(\mathrm{t}-\mathrm{M}))](\text { eq. } 2)
$$

In equations 1 and 2, Nt indicates the cell number $(\log \mathrm{CFU} / \mathrm{mL})$ at any time $(\mathrm{t})$. The results were fitted to the equations by nonlinear regression using a Marquardt algorithm running on the software Statgraphics Centurion XVI and obtaining the values of $\mathrm{A}, \mathrm{C}$ and $\mathrm{M}$ for each equation. Then, $\mu$ and $\lambda$ were calculated according to the equations for each model as described by Gupta et al. (2012).

The standardized residuals of each model were evaluated, in order to test their suitability. The homoscedasticity and independence assumptions were checked by plotting the standardized residues against the fitted values and the independent variable. Moreover, the normal distribution of the standardized residues was checked with ChiSquare, Shapiro-Wilk W, Skewness Z-score and Kurtosis Z-score tests. The root mean square errors (RMSE) were calculated, and used to compare the suitability of each model.

\subsection{Statistical analysis}

Fisher's least significant difference test ( $\mathrm{p}$-value $<0.05$ ) was performed in Statgraphics Centurion XVI to identify significant differences in the microbial counts at different sampling points and between the parameters of the different growth curves. 


\section{RESULTS AND DISCUSSION}

\subsection{Effect of RWPS on growth curves}

RWPS presented antimicrobial effects against the three tested microorganisms, but each microorganism was affected in a different way (Figures 4.1. and 4.2.). $S$. aureus was the microorganism most affected by RWPS, especially at $40 \mathrm{~g} / \mathrm{L}$. At this level, an intense bactericidal effect was observed and no count was observed after 34 hours of incubation (Figure 4.1.A). These results suggest an interesting and intense protective potential of the seasoning during food storage. RWPS at $20 \mathrm{~g} / \mathrm{L}$ initially (until 11 hours) exerted bactericidal effect, and a significant decline (0.55 log CFU/mL) was observed. However, the microbial population increased after 34 hours in relation to the initial counts. This fact can be explained by an adaptation of $S$. aureus to the medium containing RWPS. Continuous assessment of microbial growth enabled the observation of these inhibition-adaptation effects, showing clear advantages over other end-point methods. Despite microbial growth between 11 and 34 hours of incubation, a clear inhibitory effect was observed during the complete incubation period and samples were under $5 \operatorname{logs} \mathrm{CFU} / \mathrm{mL}$. The results obtained in this study agree with those of other studies on extracts from grape and wine pomace. For instance, Özkan et al. (2004) reported that $10 \mathrm{~g} / \mathrm{L}$ of grape pomace extracts produced a bactericidal effect that led to the complete inactivation of $S$. aureus. MICs of between 110 and $440 \mathrm{mg}$ gallic acid equivalents/L of red grape skin extracts, depending on the type of grape, have previously been reported (Katalinić et al., 2010; Xu et al., 2014). Furthermore, a bactericidal effect was also observed in beef patties, but higher concentrations of extracts $(100 \mathrm{~g} / \mathrm{Kg})$ were required to reach a similar level of inactivation (Sagdic et al., 2011). It is worth remarking that the seasoning in this study, in contrast to grape extracts, was produced without a chemical extraction process. Therefore, these results 
are obtained by using a more natural and economical product that is manufactured through a rapid and environmentally friendly process (García-Lomillo et al., 2014). The effects exerted by the seasoning are comparable to those exerted by other spices. For instance, Aktuğ \& Karapinar (1986) found that the concentration required to inhibit the growth of $S$. aureus was $5 \mathrm{~g} / \mathrm{L}$ for thyme, $50 \mathrm{~g} / \mathrm{L}$ for mint and $50 \mathrm{~g} / \mathrm{L}$ in the case of ground bay leaves; whereas Grohs \& Kunz (2000) reported that $20 \mathrm{~g} / \mathrm{L}$ of two spice mixtures provided complete inhibition against Staphylococcus sp. growth.
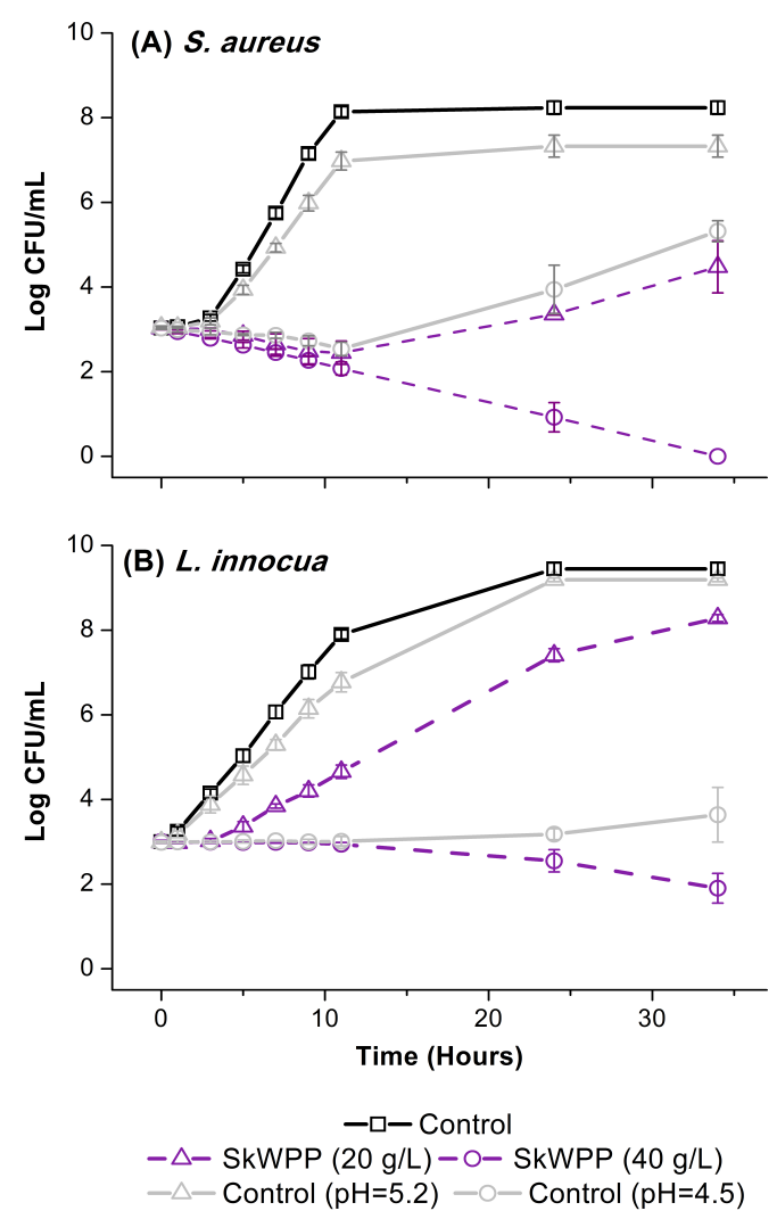

Figure 4.1. S. aureus (A) and L. innocua (B) counts (mean $\pm \mathrm{SD}, \mathrm{n}=3$ ), during incubation at $37^{\circ} \mathrm{C}$ in TSB broth supplemented with yeast extract at $\mathrm{pH}=7.2$ (Control), $\mathrm{pH} 5.2$ or 4.5 adjusted with tartaric acid and with red wine pomace seasoning (RWPS) at two different levels (20 and $40 \mathrm{~g} / \mathrm{L})$. 

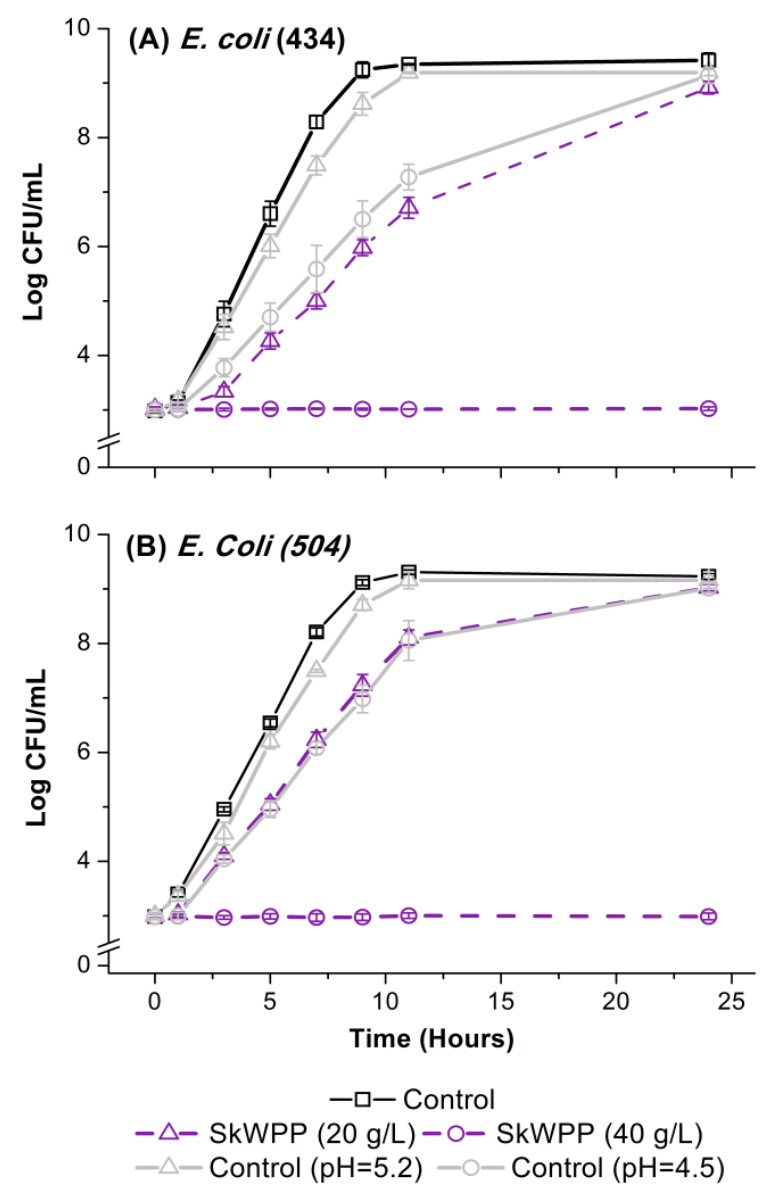

Figure 4.2. E. coli $\mathrm{CECT} 434$ (A) and E. coli $\mathrm{CECT} 504$ (B) counts (mean $\pm \mathrm{SD}, \mathrm{n}=$ 3), during incubation at $37^{\circ} \mathrm{C}$ in TSB broth supplemented with yeast extract at $\mathrm{pH}=7.2$ (Control), $\mathrm{pH} 5.2$ or 4.5 adjusted with tartaric acid and with red wine pomace seasoning (RWPS) at two different levels (20 and $40 \mathrm{~g} / \mathrm{L}$ ).

A bactericidal effect was also observed against L. innocua using RWPS at 40 $\mathrm{g} / \mathrm{L}$, although it was less intense than in the case of S. aureus (Figure 4.1.B). Bacterial counts were reduced in $1.1 \operatorname{logs} \mathrm{CFU} / \mathrm{mL}$ after 34 hours of incubation. RWPS at $20 \mathrm{~g} / \mathrm{L}$ delayed and decreased the growth of L. innocua. In this case, no significant growth was observed within the first 3 hours, and statistical differences with controls were observed at all sampling times. The highest difference was observed after 11 hours $(\sim 3.2 \operatorname{logs}$ $\mathrm{CFU} / \mathrm{mL}$ ). The results agree with works published on the antilisterial activity of grape extracts (Rhodes et al., 2006). Inhibition observed in this study at the end of the incubation period was similar to that exerted by $240 \mathrm{mg} / \mathrm{L}$ of a grape seed extract 
(Delgado Adámez et al., 2012). Leuschner \& Ielsch (2003) found that clove and red chilli (10 g/L) also presented bactericidal effect against L. monocytogenes, whereas 10 g/L garlic only presented bacteriostatic effect. Comparing the effect of the new seasoning with these spices, it seems that the new seasoning is less effective than some spices such as rosemary and clove, but more effective than others such as thyme, sage and oregano, that did not present activity. Moreover, the aroma and the flavor of the seasoning are not as intense as garlic, clove and hot chili, and may therefore be used at higher concentrations without relevant modifications in food flavor.

E. coli showed higher resistance against the new seasoning than S. aureus and L. innocua. Incubation in the presence of RWPS at $40 \mathrm{~g} / \mathrm{L}$ only produced bacteriostatic effects in both strains (Figure 4.2.). Furthermore, at $20 \mathrm{~g} / \mathrm{L}$, it slowed the growth of $E$. coli, showing different effects depending on the strain. E. coli 434 was more affected than E. coli 504. The highest differences were observed after 11 hours of incubation period. At this time, E. coli 434 incubated with RWPS at $20 \mathrm{~g} / \mathrm{L}$ showed mean values of $6.7 \operatorname{logs} \mathrm{CFU} / \mathrm{mL}$ (Figure 4.2.A), whereas samples with E. coli 504 reached $8.1 \operatorname{logs}$ CFU/mL (Figure 4.2.B). After 24 hours, counts of E. coli 504 were similar in control and 20 g/L RWPS samples, whereas counts of E. coli 434 remained slightly lower in samples with RWPS. Vaquero et al. (2007) also reported differences in the behavior of different $E$. coli strains in the presence of different wine phenolic compounds. MIC was found to range between 150 and $400 \mathrm{mg}$ GAE/L in grape skin extracts by Katalinić et al. (2010). In contrast, Corrales et al. (2010) found that white grape skin extracts (at $200 \mathrm{~g} / \mathrm{L}$ ) had no effect on $E$. coli growth using the agar diffusion method. In comparison with other spices, similar inhibition levels were produced by the incorporation of $10 \mathrm{~g} / \mathrm{L}$ ginger and mustard (Renata G. K. Leuschner \& Zamparini, 2002) and by two spice mixtures at $20 \mathrm{~g} / \mathrm{Kg}$ (Grohs \& Kunz, 2000). In contrast, garlic 
and clove exerted a more intense antimicrobial action than the seasoning in this study (Renata G. K. Leuschner \& Zamparini, 2002).

\subsection{Parameters explaining the antibacterial effect of RWPS}

The modification of $\mathrm{pH}$ and water activity, induced by RWPS, in combination with the polyphenolic content of this seasoning were suggested as the main factor to explain the antimicrobial activity against spoilage bacterial of this product (GarcíaLomillo et al., 2014). Then, the effects of these factors were also considered to explain the observed effect against the studied pathogen agents.

The incorporation of RWPS at 20 and $40 \mathrm{~g} / \mathrm{L}$ decreased the $\mathrm{pH}$ of TSB medium from 7.2 to 5.2 and 4.5 respectively, but no significant differences were detected in the water activity. Experiments were therefore conducted in parallel adjusting the $\mathrm{pH}$ of TSB broth to 5.2 and 4.5 with tartaric acid, the main acid of grape derivate products (Figures 4.1. and 4.2.). Although the four microorganisms were affected by $\mathrm{pH}$ decrease, especially S. aureus and L. innocua (Figure 4.1.), inhibition was clearly less intense than the inhibition produced by RWPS at the same $\mathrm{pH}$ values. For instance, control at $\mathrm{pH}=5.2$ presented only slight differences with control at $\mathrm{pH}=7.2$, whereas inhibition with RWPS at $20 \mathrm{~g} / \mathrm{L}$ was more intense in the three microorganisms, as previously described. Moreover, a pH decrease to 4.5, in contrast with RWPS at $40 \mathrm{~g} / \mathrm{L}$, neither produced a bacteriostatic effect against $E$. coli strains nor a bactericidal effect against S. aureus and L. innocua (Figures 4.1. and 4.2.). These results suggest that $\mathrm{pH}$ reduction is only partially responsible for the antimicrobial activity of RWPS; and other active compounds play a relevant role in the observed inhibition. This observation agrees with those of Vaquero et al. (2007), who reported that clarified wine exerted no 
antimicrobial activity, and suggested that wine phenolic compounds present a key role in the antimicrobial action.

The incorporation of RWPS increased significantly both the ITP index and the Folin Index of broths. Increases of 6 and 13\% of ITP and of 5 and 14\% of Folin Index were respectively observed after the incubation of the broth with 20 and $40 \mathrm{~g} / \mathrm{L}$ of RWPS. This fact was associated with the relevant contents of easily extractable total phenols of RWPS (24.4 mg/g of seasoning expressed as equivalents of gallic acid), mainly proanthocyanidins (39.6 mg/g of seasoning and expressed as equivalents of B1), followed by catechins $(8.8 \mathrm{mg} / \mathrm{g}$ of seasoning and expressed as equivalents of $\mathrm{D}$ catechin), and anthocyanins (2.5 mg/g of seasoning and expressed as equivalents of malvidin-3glucoside) (García-Lomillo et al., 2014).

The antimicrobial effect of phenols is well-known, and among them high molecular weight phenolic compounds seem to play a relevant role as antibacterial compounds. For example, Rhodes et al. (2006) found that polymeric phenolic of grape skins were more efficient than the corresponding monomeric fraction, especially against L. monocytogenes. According to this work, the high content of proanthocyandins detected in RWPS (García-Lomillo et al., 2014), may exert a relevant role in the observed antimicrobial activities. The observed effect may be complemented with other extractable compounds such as simple phenol acids, which exert a strong effect (Katalinić et al., 2010; Xu et al., 2014). Furthermore, together with the extractable phenolic compounds the non-extractable fraction present in RWPS could cause a synergistic effect on the antimicrobial activity of this seasoning, as suggested by other authors (Silván et al., 2013; Xu et al., 2014). 
Results showed that $S$. aureus was the most susceptive microorganism to RWPS, followed by L. innocua and E. coli (Figures 4.1. and 4.2.). These differences are in agreement with the studies using grape polyphenol-enriched extracts (Friedman et al., 2013) and other natural spices and seasonings (Kumar \& Berwal, 1998; Souza et al., 2005) and correlate well with the antimicrobial mechanisms of polyphenols. Three mechanisms have been reported to enable inhibition of phenolic compounds: damage in the cell membrane, nutrient deprivation and inactivation of intracellular material. Generally, Gram-positive bacteria (i.e S. aureus and L. innocua) are more affected by grape phenolic compounds than Gram-negative (i.e E. coli) (Oliveira et al., 2013; Xu et al., 2014). Gram-positive bacteria have no outer membrane, and phenolic compounds are able to enter the cytoplasmatic membrane and perturb their structure (Xu et al., 2014). Gram-negative bacteria, present a highly hydrophilic outer membrane acting as a strong barrier against polyphenols. Apart from the outer membrane, E. coli appears to possess other mechanisms that avoid damage produced by phenolic compounds. For example, E. coli may produce siderophores which are able to bind iron and solubilize it, enabling the transference into the cell cytoplasm (Harris et al., 1979). This fact can limit the RWPS antimicrobial effect exerted by metal deprivation. Moreover, E. coli also possesses efflux pump which can provide extra protection by removing polyphenols from the cell and avoiding the accumulation of polyphenols within the bacterium (Xu et al., 2014). In contrast, Katalinić et al. (2010) found no differences in the susceptibility of Gram-positive and Gram-negative bacteria towards grape skin extracts. Discrepancies in the results could be due to different methodology used in the assessment of the antimicrobial properties of the different phenolic compounds $(\mathrm{Xu}$ et al., 2014). 
In summary, the new seasoning under study presented interesting antimicrobial properties at similar levels than those used for other spices and seasonings in the food industry (Souza et al., 2005). These results highlight the potential of RWPS as a natural antimicrobial for the food industry.

\subsection{Comparison between microbial growth kinetic parameters}

Kinetic parameters can be used to characterize both microbial growth and inactivation. In the present study, the growth of L. innocua, E. coli 434 and E. coli 504 in TSB at pH 7.2 and 5.2 as well as TSB with RWPS at $20 \mathrm{~g} / \mathrm{L}$ were fitted to three models (Baranyi, Gompertz and Logistic), obtaining the corresponding kinetic parameters $(\lambda$ and $\mu)$ (Tables 4.1. and 4.2.).

Table 4.1. Lag phase ( $\lambda$, hours) \pm standard error of foodborne pathogens incubated at $37^{\circ} \mathrm{C}$ in TSB broth supplemented with yeast extract at $\mathrm{pH}=7.2$ (Control), at $\mathrm{pH} 5.2$ adjusted with tartaric acid and with red wine pomace seasoning (RWPS) at $20 \mathrm{~g} / \mathrm{L}$.

\begin{tabular}{ccccc}
\hline & & Baranyi & Gompertz & Logistic \\
\hline $\begin{array}{c}\boldsymbol{E} \text {. coli } \\
\text { CECT }\end{array}$ & Control & $1.154 \pm 0.171 \mathrm{a}$ & $1.519 \pm 0.226$ & $0.982 \pm 0.157$ \\
$\mathbf{4 3 4}$ & RWPS $(20 \mathrm{~g} / \mathrm{L})$ & $2.536 \pm 0.318 \mathrm{~b}$ & $2.332 \pm 0.321$ & $1.267 \pm 0.241$ \\
\hline & Control & $0.791 \pm 0.085$ & $1.242 \pm 0.200$ & $0.579 \pm 0.083 \mathrm{~b}$ \\
$\begin{array}{l}\boldsymbol{E} . \boldsymbol{c o l i} \\
\text { CECT }\end{array}$ & Control $(\mathrm{pH}=5.2)$ & $0.995 \pm 0.186$ & $1.513 \pm 0.242$ & $0.758 \pm 0.123 \mathrm{~b}$ \\
$\mathbf{5 0 4}$ & RWPS $(20 \mathrm{~g} / \mathrm{L})$ & $1.064 \pm 0.240$ & $1.347 \pm 0.180$ & $0.065 \pm 0.010 \mathrm{a}$ \\
\hline & Control & $0.759 \pm 0.227 \mathrm{a}$ & $0.509 \pm 0.068 \mathrm{a}$ & $0.891 \pm 0.071 \mathrm{a}$ \\
$\begin{array}{c}\text { L. } \\
\text { innocua }\end{array}$ & Control $(\mathrm{pH}=5.2)$ & $0.832 \pm 0.450 \mathrm{a}$ & $0.743 \pm 0.086 \mathrm{a}$ & $1.183 \pm 0.144 \mathrm{a}$ \\
& RWPS $(20 \mathrm{~g} / \mathrm{L})$ & $4.073 \pm 0.597 \mathrm{~b}$ & $3.928 \pm 1.531 \mathrm{~b}$ & $3.615 \pm 0.668 \mathrm{~b}$ \\
\hline
\end{tabular}

Different letters $(\mathrm{a}-\mathrm{c})$ denote significant differences (LSD test and $P<0.05$ ) among values of the same model for each microorganism. Values without letter do not differ significantly. 
Table 4.2. Maximum specific growth rate $(\mu, \log (\mathrm{CFU} / \mathrm{mL}) / \mathrm{h}) \pm$ standard error of foodborne pathogens incubated at $37^{\circ} \mathrm{C}$ in TSB broth supplemented with yeast extract at $\mathrm{pH}=7.2$ (Control), at $\mathrm{pH} 5.2$ adjusted with tartaric acid and with red wine pomace seasoning (RWPS) at $20 \mathrm{~g} / \mathrm{L}$.

\begin{tabular}{|c|c|c|c|c|}
\hline & & Baranyi & Gompertz & Logistic \\
\hline \multirow{3}{*}{$\begin{array}{c}\text { E. coli } \\
\text { CECT } \\
434\end{array}$} & Control & $0.951 \pm 0.031 \mathrm{c}$ & $1.123 \pm 0.092 b$ & $1.064 \pm 0.101 \mathrm{~b}$ \\
\hline & Control $(\mathrm{pH}=5.2)$ & $0.768 \pm 0.025 b$ & $0.917 \pm 0.087 \mathrm{~b}$ & $0.870 \pm 0.094 b$ \\
\hline & RWPS (20 g/L) & $0.455 \pm 0.018 \mathrm{a}$ & $0.461 \pm 0.038 \mathrm{a}$ & $0.463 \pm 0.054 \mathrm{a}$ \\
\hline \multirow{3}{*}{$\begin{array}{c}\text { E. coli } \\
\text { CECT } \\
504\end{array}$} & Control & $0.861 \pm 0.013 \mathrm{c}$ & $1.031 \pm 0.091 \mathrm{~b}$ & $1.001 \pm 0.040 \mathrm{~b}$ \\
\hline & Control (pH=5.2) & $0.766 \pm 0.023 b$ & $0.921 \pm 0.082 b$ & $0.870 \pm 0.085 b$ \\
\hline & RWPS (20 g/L) & $0.549 \pm 0.015 \mathrm{a}$ & $0.623 \pm 0.047 \mathrm{a}$ & $0.599 \pm 0.054 \mathrm{a}$ \\
\hline \multirow{3}{*}{$\begin{array}{c}L . \\
\text { innocua }\end{array}$} & Control & $0.491 \pm 0.012 \mathrm{c}$ & $0.535 \pm 0.039 \mathrm{~b}$ & $0.520 \pm 0.046 b$ \\
\hline & Control $(\mathrm{pH}=5.2)$ & $0.951 \pm 0.031 \mathrm{c}$ & $1.123 \pm 0.092 b$ & $1.064 \pm 0.101 \mathrm{~b}$ \\
\hline & RWPS (20 g/L) & $0.768 \pm 0.025 b$ & $0.917 \pm 0.087 \mathrm{~b}$ & $0.870 \pm 0.094 b$ \\
\hline
\end{tabular}

Different letters $(\mathrm{a}-\mathrm{c})$ denote significant differences (LSD test and $P<0.05)$ among values of the same model for each microorganism. Values without letter do not differ significantly.

Firstly, it was checked that the standardized residuals varied randomly around zero and that no systematic patterns were observed in any of the models. Moreover, the residuals obtained presented normal distributions tested by Chi-Square, Shapiro-Wilk W, Skewness Z-score and Kurtosis Z-score tests (p-values > 0.05). These results indicated the independence, homoscedasticity and normality of the residuals from the three proposed models. RMSE were used as a Goodness-of-Fit Index, since $\mathrm{R}^{2}$ is not recommended for non-linear models (Pérez-Rodríguez \& Valero, 2013). All the models presented adequate RMSE (Table 4.3.) within the range of those observed in similar studies (Gupta et al., 2012; Sanz-Puig et al., 2015). The Baranyi model provided the lowest RMSE values and averaged 0.127, whereas the modified Gompertz and Logistic models presented higher RMSE values (with averages of 0.162 and 0.156 respectively). The Baranyi model may be the most suitable method, although the differences were not 
relevant. Trends in the obtained parameters were also observed, showing that the logistic model provided the lowest lag phases (Table 4.1.), whereas the Baranyi models reported the lowest growth rates (Table 4.2.). Despite these trends, the differences observed between the models were not relevant. Therefore, the results indicated the suitability of the three models to assess the effect of the natural antimicrobial under study, in accordance with the suggestion of Jaiswal \& Jaiswal (2015).

Table 4.3. Root mean square error (RMSE) values of the growth curve adjusted in each model in foodborne pathogens incubated at $37^{\circ} \mathrm{C}$ in TSB broth supplemented with yeast extract at $\mathrm{pH}=7.2$ (Control), at $\mathrm{pH} 5.2$ adjusted with tartaric acid and with red wine pomace seasoning (RWPS) at $20 \mathrm{~g} / \mathrm{L}$

\begin{tabular}{ccccc}
\hline & & Baranyi & Gompertz & Logistic \\
\hline \multirow{2}{*}{. coli } & Control & 0.143 & 0.187 & 0.166 \\
CECT 434 & Control $(\mathrm{pH}=5.2)$ & 0.150 & 0.209 & 0.180 \\
& RWPS $\left(20 \mathrm{~g} / \mathrm{L}^{1}\right)$ & 0.141 & 0.135 & 0.152 \\
\hline \multirow{2}{*}{ coli } & Control & 0.064 & 0.186 & 0.137 \\
CECT 504 & Control (pH=5.2) & 0.131 & 0.192 & 0.159 \\
& RWPS (20 g/L) & 0.132 & 0.147 & 0.136 \\
\hline \multirow{2}{*}{ L. innocua } & Control (pH=5.2) & 0.152 & 0.119 & 0.139 \\
& RWPS (20 g/L) & 0.120 & 0.156 & 0.203 \\
\hline
\end{tabular}

\subsection{Effect of RWPS on growth and inactivation kinetic parameters}

The antimicrobial potential of natural compounds is usually evaluated by endpoint methods. However, these methods did not provide information on the effect at sub-MIC levels or on the kinetics of the inhibition (López-Malo Vigil et al., 2005). In food products, an extension of the lag phase or a reduction in the growth rate may be enough to control a pathogenic population without requiring high levels of the antimicrobials. Accordingly, kinetic models permitted the evaluation of relevant 
modifications in the kinetic growth parameters of the three microorganisms under study.

In general, the incorporation of RWPS produced more relevant modifications in the maximum growth of the microorganisms than in the duration of the lag phase (Tables 4.1. and 4.2.). RWPS at $20 \mathrm{~g} / \mathrm{L}$ extended the lag phase of L. innocua by 7 times, and the lag phase of E. coli by around 1.5-2 times (Table 4.1.). Furthermore, RWPS at $20 \mathrm{~g} / \mathrm{L}$ produced significant reductions in the maximum specific growth rate of the three tested microorganisms (Table 4.2.). E. coli 424 and L. innocua were more susceptible to RWPS and their growth rate was reduced by half (Table 4.2.), whereas only a $35 \%$ reduction was observed in E. coli 504 . Similar modifications in the lag phase were reported in connection with a seaweed polyphenolic extract used at 7.5-15 g/L (Gupta et al., 2012). Although the concentration of RWPS required to achieve similar inactivation rates was higher than other purified natural extracts, it is worth remarking that the developed seasoning is more economical, which could justify its application in food products.

The reduction of $\mathrm{pH}$ to 5.2 (the same $\mathrm{pH}$ value than the medium with $20 \mathrm{~g} / \mathrm{L}$ RWPS) produced a significant reduction of growth rates (only in the Baranyi models), but not in the duration of the lag phase (Tables 4.1. and 4.2.). Significant differences between the lag phase and the maximum growth rate of controls at $\mathrm{pH} 5.2$ and with RWPS were observed in both E. coli and L. innocua, although not in all the studied models. In agreement with previous comments, $\mathrm{pH}$ reduction may partially contribute to reduce the maximum growth rate. However, other antimicrobial compounds seem to present a higher impact on the observed effect due to the clear difference between controls at 5.2 and samples with RWPS at $20 \mathrm{~g} / \mathrm{L}$. Some results found in the literature 
suggest that compounds from different phenolic families may present different mechanisms of action with different impacts on growth kinetic parameters (Jaiswal \& Jaiswal, 2015). The extension of the lag phase may be ascribed to the phenolic ability to deprive nutrients (metals and proteins) from the medium. It is known that bacteria require metal accumulation such as iron, calcium, manganese and calcium to adapt to the new medium successfully and to start their essential metabolic machinery for the exponential growth phase (Harris et al., 1979). Apart from metal chelation, polyphenols, especially highly polymerized compounds, are able to precipitate proteins. Interestingly, RWPS may interact with proteins producing non-reducible cross-links, which may decrease the protein availability to microorganisms (Garcia-Lomillo et al., 2016). These results suggest that highly polymerized polyphenols are more effective, due most likely to nutrient deprivation.

The Baranyi model was also applied to describe the inactivation kinetics produced by RWPS against L. innocua and S. aureus. Inactivation of L. innocua with RWPS at $40 \mathrm{~g} / \mathrm{L}$ was characterized by a lag phase of $17.33 \pm 2.26$ hours and an inactivation rate of $0.0648 \pm 0.0107 \log (\mathrm{CFU} / \mathrm{mL}) / \mathrm{h}$. S. aureus was more strongly affected and the inactivation rate was $0.0908 \pm 0.0031 \log (\mathrm{CFU} / \mathrm{mL}) / \mathrm{h}$ with no lag phase observed for RWPS at $40 \mathrm{~g} / \mathrm{L}$. In the case of RWPS at $20 \mathrm{~g} / \mathrm{L}$, the rate was $0.0764 \pm 0.0205 \log$ $(\mathrm{CFU} / \mathrm{mL}) / \mathrm{h}$ but the inactivation was only effective during the first 11 hours. These inactivation rates are lower than those produced by other natural compounds such as oregano essential oils and cauliflower powdered residue (Sanz-Puig et al., 2015; Skandamis \& Nychas, 2000). 


\section{CONCLUSIONS}

RWPS has been shown to present interesting antimicrobial properties against the three pathogens under study. The effects depended on RWPS concentration and the microorganism. RWPS at $40 \mathrm{~g} / \mathrm{L}$ presented bactericidal effect against $L$. innocua and $S$. aureus and bacteriostatic activity against the two strains of E. coli assessed. RPWS at $20 \mathrm{~g} / \mathrm{L}$ completely inhibited the growth of $S$. aureus, and extended the lag phases and decreased the growth rate of both E. coli and L. innocua. The present study proposes a new sustainable solution to improve the safety of food products by reutilizing an agricultural by-product that is currently undervalued.

\section{REFERENCES}

Aktuğ, Ş. E., \& Karapinar, M. (1986). Sensitivity of some common food-poisoning bacteria to thyme, mint and bay leaves. International Journal of Food Microbiology, 3(6), 349-354.

Banatvala, N., Griffin, P. M., Greene, K. D., Barrett, T. J., Bibb, W. F., Green, J. H., Wells, J. G., Siegler, R. L., Pavia, A., Hedberg, K., MacDonald, K., Belongia, E., Kulhanjian, J., Janner, D., Morrell, R. E., Miller, K., Atkin, B., De Beukelaer, M., Waldo, B., Houser, M. T., Wead, T., Wendell, P., Knupp, C., Gerber, R. A., Frohlich, H., Bunchman, T., Wood, E., Ornt, D., Loveys, A., Powell, K., Baetz-Greenwalt, B., Bastian, J., Blumberg, D., Cherry, J. D., Foreman, J., Gauthier, B., Trachtman, H., Frank, R., Rogers, J., Lettau, L., Manian, F. A., Alejos, J., Calk, T. E., Cunningham, C., Guyton, D., Ross, S., \& Hanevold, C. (2001). The United States national prospective hemolytic uremic syndrome study: Microbiologic, serologic, clinical, and epidemiologic findings. Journal of Infectious Diseases, 183(7), 1063-1070.

Baranyi, J., \& Roberts, T. A. (1994). A dynamic approach to predicting bacterial growth in food. International Journal of Food Microbiology, 23(3), 277-294.

Corrales, M., Fernandez, A., Vizoso Pinto, M. G., Butz, P., Franz, C. M. A. P., Schuele, E., \& Tauscher, B. (2010). Characterization of phenolic content, in vitro biological activity, and pesticide loads of extracts from white grape skins from organic and conventional cultivars. Food and Chemical Toxicology, 48(12), 3471-3476.

Davidson, P. M., \& Branen, A. L. (2005). Food Antimicrobials - An Introduction. Antimicrobials in Food, Third Edition, (pp. 1-10): CRC Press.

Delgado Adámez, J., Gamero Samino, E., Valdés Sánchez, E., \& González-Gómez, D. (2012). In vitro estimation of the antibacterial activity and antioxidant capacity 
of aqueous extracts from grape-seeds (Vitis vinifera L.). Food Control, 24(1-2), 136-141.

EFSA. (2009). Assessment of the Public Health significance of meticillin resistant Staphylococcus aureus (MRSA) in animals and foods. EFSA Journal, 993, 173.

EFSA, \& ECDC. (2015). The European Union summary report on trends and sources of zoonoses, zoonotic agents and food-borne outbreaks in 2013. EFSA Journal 2015, 13(1), 1-165.

Friedman, M., Henika, P. R., \& Levin, C. E. (2013). Bactericidal Activities of HealthPromoting, Food-Derived Powders Against the Foodborne Pathogens Escherichia coli, Listeria monocytogenes, Salmonella enterica, and Staphylococcus aureus. Journal of Food Science, 78(2), M270-M275.

Garcia-Lomillo, J., González-SanJosé, M., Skibsted, L., \& Jongberg, S. (2016). Effect of Skin Wine Pomace and Sulfite on Protein Oxidation in Beef Patties During High Oxygen Atmosphere Storage. Food and Bioprocess Technology, 9(3), 532-542.

García-Lomillo, J., González-SanJosé, M. L., Del Pino-García, R., Rivero-Pérez, M. D., \& Muñiz-Rodríguez, P. (2014). Antioxidant and antimicrobial properties of wine byproducts and their potential uses in the food industry. Journal of Agricultural and Food Chemistry, 62(52), 12595-12602.

Gibson, A. M., Bratchell, N., \& Roberts, T. A. (1987). The effect of sodium chloride and temperature on the rate and extent of growth of Clostridium botulinum type A in pasteurized pork slurry. Journal of Applied Bacteriology, 62(6), 479-490.

González San José, M. L., García Lomillo, J., Del Pino García, R., Dolores Rivero, M., \& Muñiz Rodríguez, P. (2015). Sazonador de origen vegetal con propiedades conservantes, sustitutivo de la sal, y procedimiento de obtención del mismo. ES2524870 B2. Spain.

Grohs, B.-M., \& Kunz, B. (2000). Use of spice mixtures for the stabilisation of fresh portioned pork. Food Control, 11(6), 433-436.

Gupta, S., Cox, S., Rajauria, G., Jaiswal, A., \& Abu-Ghannam, N. (2012). Growth Inhibition of Common Food Spoilage and Pathogenic Microorganisms in the Presence of Brown Seaweed Extracts. Food and Bioprocess Technology, 5(5), 1907-1916.

Harris, W. R., Carrano, C. J., Cooper, S. R., Sofen, S. R., Avdeef, A. E., McArdle, J. V., \& Raymond, K. N. (1979). Coordination chemistry of microbial iron transport compounds. 19. Stability constants and electrochemical behavior of ferric enterobactin and model complexes. Journal of the American Chemical Society, 101(20), 6097-6104.

Jaiswal, A. K., \& Jaiswal, S. (2015). 12 - Modelling the effects of natural antimicrobials as food preservatives. T. M. Taylor (Ed.), Handbook of Natural Antimicrobials for Food Safety and Quality, (pp. 259-284). Oxford: Woodhead Publishing. 
Katalinić, V., Možina, S. S., Skroza, D., Generalić, I., Abramovič, H., Miloš, M., Ljubenkov, I., Piskernik, S., Pezo, I., Terpinc, P., \& Boban, M. (2010). Polyphenolic profile, antioxidant properties and antimicrobial activity of grape skin extracts of 14 Vitis vinifera varieties grown in Dalmatia (Croatia). Food Chemistry, 119(2), 715-723.

Kumar, M., \& Berwal, J. S. (1998). Sensitivity of food pathogens to garlic (Allium sativum). Journal of Applied Microbiology, 84(2), 213-215.

Le Loir, Y., Baron, F., \& Gautier, M. (2003). Staphylococcus aureus and food poisoning. Genetics and Molecular Research, 2(1), 63-76.

Leuschner, R. G. K., \& Ielsch, V. (2003). Antimicrobial effects of garlic, clove and red hot chilli on Listeria monocytogenes in broth model systems and soft cheese. International Journal of Food Sciences and Nutrition, 54(2), 127-133.

Leuschner, R. G. K., \& Zamparini, J. (2002). Effects of spices on growth and survival of Escherichia coli 0157 and Salmonella enterica serovar Enteritidis in broth model systems and mayonnaise. Food Control, 13(6-7), 399-404.

López-Malo Vigil, A., Palou, E., Parish, M. E., \& Davidson, P. M. (2005). Methods for Activity Assay and Evaluation of Results. Antimicrobials in Food, Third Edition, (pp. 659-680): CRC Press.

Oliveira, D. A., Salvador, A. A., Smânia Jr, A., Smânia, E. F. A., Maraschin, M., \& Ferreira, S. R. S. (2013). Antimicrobial activity and composition profile of grape (Vitis vinifera) pomace extracts obtained by supercritical fluids. Journal of Biotechnology, 164(3), 423-432.

Özkan, G., Sagdiç, O., Göktürk Baydar, N., \& Kurumahmutoglu, Z. (2004). Antibacterial activities and total phenolic contents of grape pomace extracts. Journal of the Science of Food and Agriculture, 84(14), 1807-1811.

Pérez-Rodríguez, F., \& Valero, A. (2013). Predictive Models: Foundation, Types, and Development. Predictive Microbiology in Foods, vol. 5 (pp. 25-55): Springer New York.

Rhodes, P. L., Mitchell, J. W., Wilson, M. W., \& Melton, L. D. (2006). Antilisterial activity of grape juice and grape extracts derived from Vitis vinifera variety Ribier. International Journal of Food Microbiology, 107(3), 281-286.

Ribereau-Gayón, J., Peynaud, E., Sudraud, P., \& Ribereau-Gayón, P. (1982). Traité d'oenologie. Sciences et techniques du vin. Tome 1. Analyse et contrôle des vins. Paris, France.

Sagdic, O., Ozturk, I., Yilmaz, M. T., \& Yetim, H. (2011). Effect of Grape Pomace Extracts Obtained from Different Grape Varieties on Microbial Quality of Beef Patty. Journal of Food Science, 76(7), M515-M521.

Sanz-Puig, M., Pina-Pérez, M. C., Rodrigo, D., \& Martínez-López, A. (2015). Antimicrobial activity of cauliflower (Brassica oleracea var. Botrytis) byproduct against Listeria monocytogenes. Food Control, 50, 435-440.

Silván, J. M., Mingo, E., Hidalgo, M., de Pascual-Teresa, S., Carrascosa, A. V., \& Martinez-Rodriguez, A. J. (2013). Antibacterial activity of a grape seed extract and its fractions against Campylobacter spp. Food Control, 29(1), 25-31. 
Singleton, V. L., \& Rossi, J. A., Jr. (1965). Colorimetry of Total Phenolics with Phosphomolybdic-Phosphotungstic Acid Reagents. American Journal of Enology and Viticulture, 16(3), 144-158.

Skandamis, P. N., \& Nychas, G. J. E. (2000). Development and evaluation of a model predicting the survival of Escherichia coli O157:H7 NCTC 12900 in homemade eggplant salad at various temperatures, pHs, and oregano essential oil concentrations. Applied and Environmental Microbiology, 66(4), 1646-1653.

Souza, E. L. d., Stamford, T. L. M., Lima, E. d. O., Trajano, V. N., \& Barbosa Filho, J. M. (2005). Antimicrobial effectiveness of spices: an approach for use in food conservation systems. Brazilian Archives of Biology and Technology, 48, 549558.

Vaquero, M. J. R., Alberto, M. R., \& de Nadra, M. C. M. (2007). Antibacterial effect of phenolic compounds from different wines. Food Control, 18(2), 93-101.

Xu, C., Yagiz, Y., Hsu, W.-Y., Simonne, A., Lu, J., \& Marshall, M. R. (2014). Antioxidant, Antibacterial, and Antibiofilm Properties of Polyphenols from Muscadine Grape (Vitis rotundifolia Michx.) Pomace against Selected Foodborne Pathogens. Journal of Agricultural and Food Chemistry, 62(28), 6640-6649. 



\section{ChAPTER 5:}

ANTIOXIDANT EFFECT OF SEASONINGS

DERIVED FROM WINE POMACE IN

Refrigerated ANd Frozen BeEF PATTIES 



\section{Presentación}

La oxidación de la fracción lipídica es una de las reacciones que más limitan la vida útil de los alimentos ya que causa el desarrollo de olores y sabores extraños, desagradables y rancios. En el caso de los productos cárnicos, este problema es incluso más relevante debido a su alto contenido en grasa y sal que pueden contribuir a la reducción de la calidad del producto durante su almacenamiento. Por todo ello, para la industria alimentaria en general, y para la cárnica en particular, resultan de gran interés la búsqueda de nuevos antioxidantes, mejor si son naturales, que inhiban la oxidación lipídica.

Los valores de actividad antioxidante global (ABTS) y la capacidad para inhibir la oxidación lipídica en el método Rancimat de los productos elaborados desde orujos tintos (capítulo 2) sugirieron su posible uso como antioxidantes naturales capaces de inhibir la oxidación lipídica de hamburguesas. Esta opción se estudia en el presente capítulo en el que hamburguesas con un $2 \%$ de los tres sazonadores son sometidas a diversas condiciones de almacenamiento.

\section{Resultados más relevantes}

Los tres sazonadores mostraron capacidad de inhibir la oxidación lipídica tanto en atmósfera convencional como modificada, pero el sazonador procedente del orujo libre de pepitas fue el más eficaz, siendo incluso más eficiente que los sulfitos. Resultados similares se obtuvieron con hamburguesas frescas y cocinadas envasadas a vacío y conservadas en condiciones de almacenamiento en congelación. 



\title{
Chapter 5: Antioxidant Effect of Seasonings Derived from Wine
}

\section{Pomace in Refrigerated and Frozen Beef Patties}

\begin{abstract}
The food industry is constantly looking for natural solutions to retard lipid oxidation and to extend the shelf-life of foodstuffs. Beef patties made with three natural seasonings derived from red wine pomace showed higher stability against lipid oxidation than control patties stored under refrigeration conditions in a high-oxygen atmosphere. The seasoning produced from seedless wine pomace presented the highest activity in comparison with the other seasonings. It showed higher efficacy than sulfites in delaying the formation of thiobarbituric acid reactive substances (TBARS) and other volatile organic compounds related to lipid oxidation. The seasoning also retarded the development of lipid oxidation in cooked and raw beef patties stored under freezing conditions. In the frozen samples, sulfites presented a contradictory effect, since it inhibited hexanal formation, but promoted the formation of TBARS. The results of the present study reveal that the seasoning is able to limit the development of lipid oxidation, extending the shelf-life of meat products without using synthetic antioxidants.
\end{abstract}

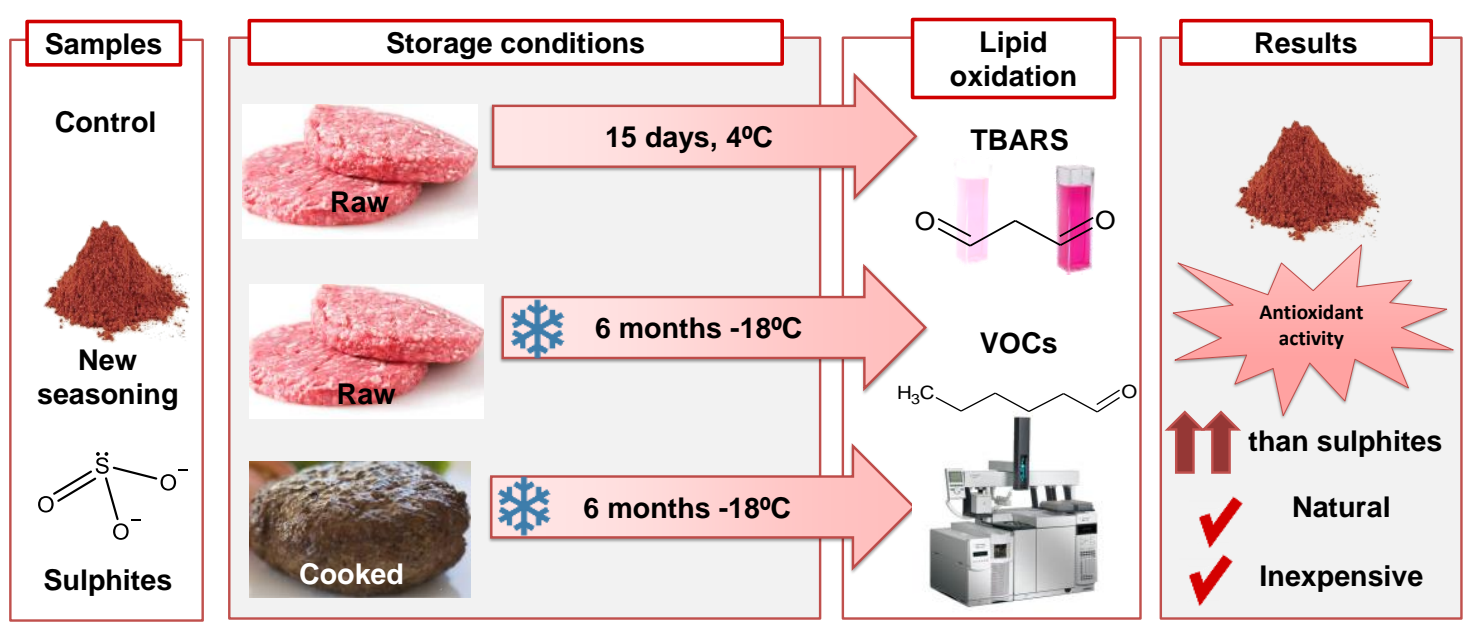




\section{INTRODUCTION}

Lipid oxidation is one of the major factors that limits the shelf-life of meat products. It involves the formation of hydroperoxides that are easily broken down to form low molecular weight compounds (Kanner, 1994; Zhao et al., 1994). Different volatile organic compounds (VOCs) such as alkanes, alkenes, aldehydes, ketones, alcohols, esters and acids, are extensively formed, causing rancid and unpleasant flavors and reducing the sensorial quality of meat products (Frankel, 1983; Kanner, 1994). Furthermore, lipid oxidation decreases the nutritional value of foodstuffs due to the loss of essential compounds such as polyunsaturated fatty acids (Kanner, 1994). Meat products are affected by lipid oxidation, as they usually contain high levels of fat and pro-oxidants such as salt. Furthermore, processes such as grinding or cooking also decrease the stability against lipid oxidation, due to structural degradation and the release of pro-oxidants (Alfawaz et al., 1994; Kanner, 1994).

Nowadays, meat products for storage under refrigerated conditions are usually packaged under high-oxygen atmospheres $\left(70-80 \% \mathrm{O}_{2}, 20-30 \% \mathrm{CO}_{2}\right)$. This type of atmosphere maintains the attractive bright red color associated with fresh meat and present antimicrobial effect. However, storage with high levels of oxygen also accelerates the process of lipid oxidation and the appearance of off-flavors (Zhao et al., 1994).

The development of a global meat market and the increase of distance between producers and consumers have increased the use of freezing as a preservation technique (Leygonie et al., 2012). Low temperatures and low levels of available water drastically reduce microbial and chemical reactions, thereby extending the shelf-life of these products. However, freezing also modifies the homeostasis of the meat system, due to 
the cryoconcentration of solutes in the unfrozen phase. These changes may damage cell membrane leading to leakage of intracellular pro-oxidants such as lipases and metals, affecting the chemical stability of the product (Leygonie et al., 2012). Moreover, the catering and retail sector is increasingly interested in ready-to-eat foods that can be stored over long periods. Some consumers also prefer cooked products due to their convenience and their shorter preparation times. However, storage of cooked products is usually linked to extensive lipid oxidation and the development of the unpleasant “warmed-over flavor" (Carpenter et al., 2007; Igene et al., 1979).

Several chemical additives can be used to inhibit lipid oxidation and consequently extend the shelf-life of meat products (Cornelius \& Lilian, 2005). For instance, sulfites are mainly applied as antimicrobial agents but also exert an important function as antioxidant. However, their consumption has been linked to allergic reactions and safety concerns over their long-term consumption have yet to be clarified (Cornelius \& Lilian, 2005). Moreover, consumer rejection of chemical additives is growing and the food industry is constantly looking for natural additives. Natural products, such as spices and plant extracts, have been proposed as natural antioxidants to replace the use of chemical additives (Brewer, 2011; Lindberg Madsen \& Bertelsen, 1995; Yanishlieva et al., 2006). Due to the complex reactions involved in lipid oxidation of foodstuffs, the efficacy of natural antioxidants may be affected under different storage conditions (Lindberg Madsen \& Bertelsen, 1995). For instance, different herbs and spices such as curry and cinnamon showed high antioxidant protection in refrigerated storage of minced chicken meat, but not at the frozen storage (El-Alim et al., 1999). Then, if their full potential is to be evaluated, natural antioxidants should be tested under different conditions. 
Different seasonings recently developed from wine pomace presented excellent properties to be used as food ingredients. The seasonings are rich in fiber, minerals, especially potassium, and in phenolic compounds, including extractable and nonextractable fractions such as catechins, anthocyanins and proanthocyanidins, among other phenols (García-Lomillo et al., 2014). They have successfully been applied in different food matrices and have shown a preservative effect in low salt patties with high levels of consumer acceptance (González-SanJosé et al., 2014). Furthermore, the seasonings were found to successfully inhibit lipid oxidation under accelerated oxidative conditions in the Rancimat test, which points out to their potential use as natural antioxidants in the food industry (García-Lomillo et al., 2014).

The main aim of this work is to study the potential of red wine pomace seasonings (RWPSs) to retard or inhibit lipid oxidation in beef patties under different storage conditions (raw refrigerated under high-oxygen atmosphere as well as raw and cooked frozen vacuum-packaged patties), comparing the antioxidant effect with the antioxidant capacity of sulfites, a common additive in meat patties.

\section{MATERIALS AND METHODS}

\subsection{Material}

Beef meat was obtained from a local supplier (Gros Mercat, Burgos, Spain). Common salt, food grade starch and a commercially available mixture of phosphates provided by Doscadesa (Murcia, Spain) and sodium metabisulfite $\left(\mathrm{Na}_{2} \mathrm{~S}_{2} \mathrm{O}_{5}\right)$ (Panreac, Barcelona, Spain) were used in the formulation of beef patties. The seasonings under study were prepared at the pilot plant of the Food Technology Department of University of Burgos (Spain), following the process described by González San José et al. (2015). The seasoning obtained directly from whole red wine pomace was labeled as 
WRWPS (whole red wine pomace seasoning). A second seasoning was obtained from seedless red wine pomace and was labeled as SkRWPS (skin red wine pomace seasoning). The third seasoning, obtained from the seeds that had been separated, was labeled SdRWPS (seed red wine pomace seasoning). The chemical and phenolic composition as well as their antimicrobial capacity of the three seasonings were previously described (García-Lomillo et al., 2014).

For lipid oxidation assessment, perchloric acid was purchased from VWR International (Barcelona, Spain), and 2-thiobarbituric acid, cyclopentanone, dichloromethane, hexanal, 1,1,3,3-tetraethoxypropane were purchased from Sigma (St. Louis, USA).

\subsection{Patty preparation}

Control beef patties were prepared by mixing $920 \mathrm{~g}$ of previously chopped and minced meat, $12 \mathrm{~g}$ of potato starch and $50 \mathrm{~mL}$ of water in which $3 \mathrm{~g}$ of a commercially available mix of food grade phosphates had previously been dissolved, and the corresponding quantity of salt to obtain a final concentration of $1.5 \mathrm{~g}$ of salt per $\mathrm{kg}$ of patty. Beef patties with seasonings were formulated in the same way, but suspending the corresponding amount of seasoning in water to obtain a final concentration of $2 \%$ $(w / w)$. Sulfite samples were similarly prepared obtaining a final concentration of 300 $\mathrm{mg}$ of $\mathrm{SO}_{2}$ per $\mathrm{kg}$ of patty (300 ppm). Ingredients were mixed in a food processor for 5 minutes and patties of 100 grams were manually formed and packaged or cooked and then packaged. Cooked samples were processed according to the procedure described by Carpenter et al. (2007) in a fan-assisted oven (Berto's, Padova, Italy) previously heated at $180^{\circ} \mathrm{C}$, until an internal temperature of $72^{\circ} \mathrm{C}$ was reached (8 minutes) and subsequently maintained for 8 minutes. 
Raw patties were stored under two different conditions, high-oxygen atmosphere $\left(70 \% \mathrm{O}_{2} / 30 \% \mathrm{CO}_{2}\right)$ and refrigeration, and vacuum packing and freezing. In the high-oxygen atmosphere, samples were packaged in trays of polyethylene/ethylene vinyl alcohol/polystyrene (PE/EVOH/PS) (Sanviplast, Barcelona, Spain) with permeability to oxygen of $0.99 \mathrm{~cm}^{3} /\left(\mathrm{m}^{2}\right.$ day atm). They were then sealed using a polyethylene terephthalate polyvinylidene chloride/polyethylene (PETPVdC/PE) film with an oxygen permeability of $7 \mathrm{~cm}^{3} /\left(\mathrm{m}^{2}\right.$ day atm) (Amcor, Burgos, Spain). The vacuum-packaged samples (raw and cooked), were sealed in polyamide/polyethylene (PA/PE) bags $(20 / 70 \mu \mathrm{m})$ (Vacioplast, Salamanca, Spain) with an oxygen permeability lower than $40 \mathrm{~cm}^{3} /\left(\mathrm{m}^{2}\right.$ day atm). The samples were frozen using a conventional freezer working at $-30^{\circ} \mathrm{C}$ stored over 6 months at $-18^{\circ} \mathrm{C}$.

Sampling of the refrigerated patties (conserved at $4^{\circ} \mathrm{C}$ ) was conducted at days 0 , 4, 8, 12 and 15 days of storage, and at months $0,2,4$ and 6 of the frozen samples. Frozen samples were thawed at $4^{\circ} \mathrm{C}$ for 12 hours before analysis. This study was performed in duplicate and, in each experiment, three independent replicates (trays or bags) were considered on each sampling date.

The chemical composition of the beef patties was analyzed using a FoodScan ${ }^{\mathrm{TM}}$ near-infrared spectrophotometer (Foss Electric A/S, Hillerød, Denmark) and data processing done with ISIscan ${ }^{\mathrm{TM}}$ Software.

\subsection{Thiobarbituric acid reactive substances (TBARS) analysis}

TBARS method was conducted according to the method proposed by Tarladgis et al. (1960) with minor modifications. Briefly, samples were homogenized in $3.86 \%$ perchloric acid, filtered and distilled. Three $\mathrm{mL}$ of the resulting distillate were mixed with $1 \mathrm{~mL}$ of $0.04 \mathrm{M}$ of 2-thiobarbituric acid in perchloric acid (10\%) and incubated at 
$100^{\circ} \mathrm{C}$ for 45 minutes. After incubation, samples were cooled and their absorbance was measured at $532 \mathrm{~nm}$ using a U-2000 Hitachi spectrophotometer (Tokyo, Japan) against a blank where sample was replaced with $3 \mathrm{~mL}$ of perchloric acid. Quantification was conducted by preparing a standard curve with tetraethoxypropane and the results were expressed in ppm of malondialdehyde (MDA). The quantification limit (0.08 ppm of MDA) of the method was calculated using the DETARCHI software (Sarabia \& Ortiz, 1994).

\subsection{Analysis of volatile organic compounds (VOCs)}

Volatile organic compounds were evaluated by a headspace solid-phase dynamic extraction (HS-SPDE) coupled with gas chromatography-mass spectrometry (GC-MS) (Agilent Technologies 6890N) fully controlled by a CTC-CombiPAL autosampler (Bender and Hobein, Zurich, Switzerland), following the method optimized by Corcuera-Tecedor (2013). Samples were introduced in a glass vial with $10 \mathrm{~mL}$ of headspace (Chromacol Ltd. Herts, United Kingdom), mixed with $5 \mu$ l of a ciclopentanone:dichloromethane (1:9) solution and sealed using a metallic cap with a chlorobutyl/polytetrafluoroethylene seal (Chromacol Ltd. Herts). Extraction was conducted in an incubation station at $55^{\circ} \mathrm{C}$, using a previously conditioned SPDEsyringe with a non-polar PDMS/AC (90\% polydimethylsiloxane and 10\% activated carbon) needle (60 extraction strokes). After extraction, VOCs were then desorbed from the fiber in the injection port at $250^{\circ} \mathrm{C}$, using helium as the carrier agent. Separation was conducted in 007-WAX capillary column (Quadrex Corporation, New Haven, USA) (60 $\mathrm{m}$ length, $0.32 \mathrm{~mm}$ inside diameter and $1 \mu \mathrm{m}$ film thickness). Compounds were identified by comparing their mass spectra with those found in the Wiley 7th and NIST 98 libraries and confirmed with their retention times. The retention index was calculated in relation to a series of standard alkanes (C6-C18) that were used 
for calculating Kovats indexes. The results were expressed as relative areas of each chromatographic peak (compounds) in relation to the peak area of the internal standard (arbitrary units, AU) that was used.

\subsection{Statistical analysis}

Statistical analysis was performed using StatGraphics ${ }^{\circledR}$ Centurion XVI. Fisher's least significant difference test was performed in order to identify significant differences between different formulations and at different days of storage ( $p$-value < $0.05)$

\section{RESULTS AND DISCUSSION}

\subsection{Chemical analysis of beef patties}

The main compositional parameters of the raw and the cooked samples were measured and significant differences were not observed between the different batches. Raw samples averaged $63.0 \pm 1.3 \%$ of moisture, $16.2 \pm 0.3 \%$ of total protein and 13.4 $\pm 0.9 \%$ of total lipid. Cooked samples presented values of $64.3 \pm 1.3 \%$ moisture, $23.8 \pm$ $1.2 \%$ of protein and $9.9 \pm 0.9 \%$ of total lipid content.

\subsection{Lipid oxidation under high-oxygen atmosphere and refrigeration} conditions

TBARS analysis is a widely used indicator to evaluate secondary lipid oxidation during the storage of meat products. It is usually considered a measure of the MDA content, although other aldehydes may also participate in the reaction (Kanner, 1994).

Previous studies reported that SkRWPS showed a higher antioxidant effect in the Rancimat test in comparison to SdRWPS and WRWPS (García-Lomillo et al., 2014). The present study also showed different inhibition capacities for each seasoning (Figure 5.1.). 


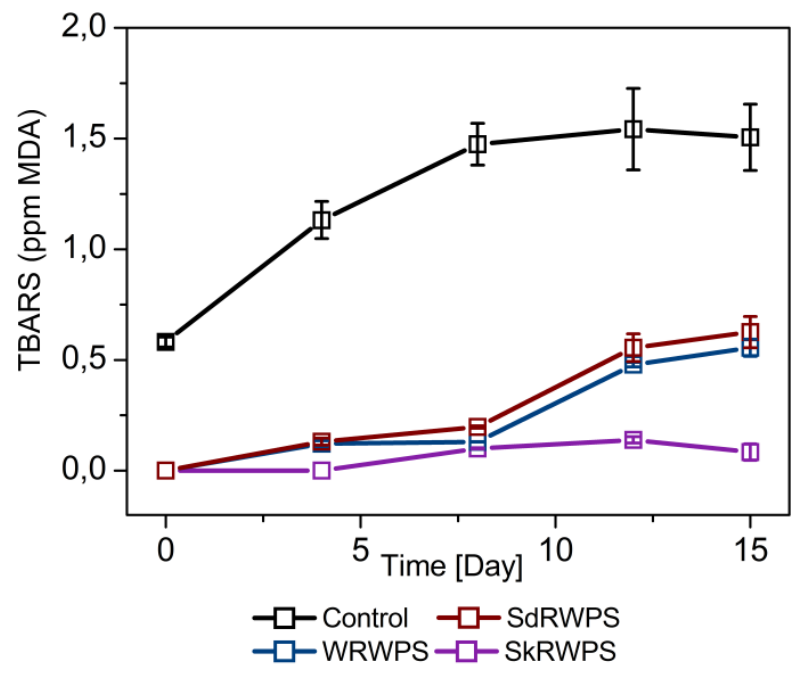

Figure 5.1. Formation of TBARS in beef patties without antioxidants (Control), with the addition red wine pomace seasonings (Seed RWPS, Whole RWPS or Skin RWPS at $2 \% \mathrm{w} / \mathrm{w})$ stored under high-oxygen atmosphere $\left(70 \% \mathrm{O}_{2} / 30 \% \mathrm{CO}_{2}\right)$ for 15 days at 4 ${ }^{\circ} \mathrm{C}$. Points show mean values of three replicates, and bars indicate standard deviations at each sampling point.

TBARS values of the control patties increased during refrigerated storage, due to the lipid instability of meat products stored under a high-oxygen atmosphere (Frankel, 1983). Patties are minced meat products with high fat and relatively high salt contents, factors that enhance lipid oxidation (Alfawaz et al., 1994; Kanner, 1994). These facts could explain the extensive formation of TBARS not only during storage but also during patty preparation. The three seasonings under study were able to prevent lipid oxidation during patty processing and subsequent storage, but with different levels of efficacy. SkRWPS was the most effective inhibiting lipid oxidation completely until the end of storage (two weeks). WRWPS and SdRWPS were also able to delay the onset of lipid oxidation for around one week and to reduce the oxidation rate significantly. Then, patties made with these seasonings showed TBARS values that were $55 \%$ lower than the control patties, and no significant differences were observed between them. 
In view of the high effectiveness of SkRWPS against lipid oxidation of patties, further experiments were conducted to compare the effect of this seasoning with sulfites (Figure 5.2.). The results obtained in the two assays showed that sulfite was less efficient than SkRWPS, which totally inhibited TBARS formation. Sulfites were not able to retard the onset of the oxidation, but they were able to reduce the intensity of lipid oxidation, and lower TBARS values than in control samples were obtained at all sampling points. At the end of storage, formulation with sulfites presented $55 \%$ lower TBARS values than the control samples.

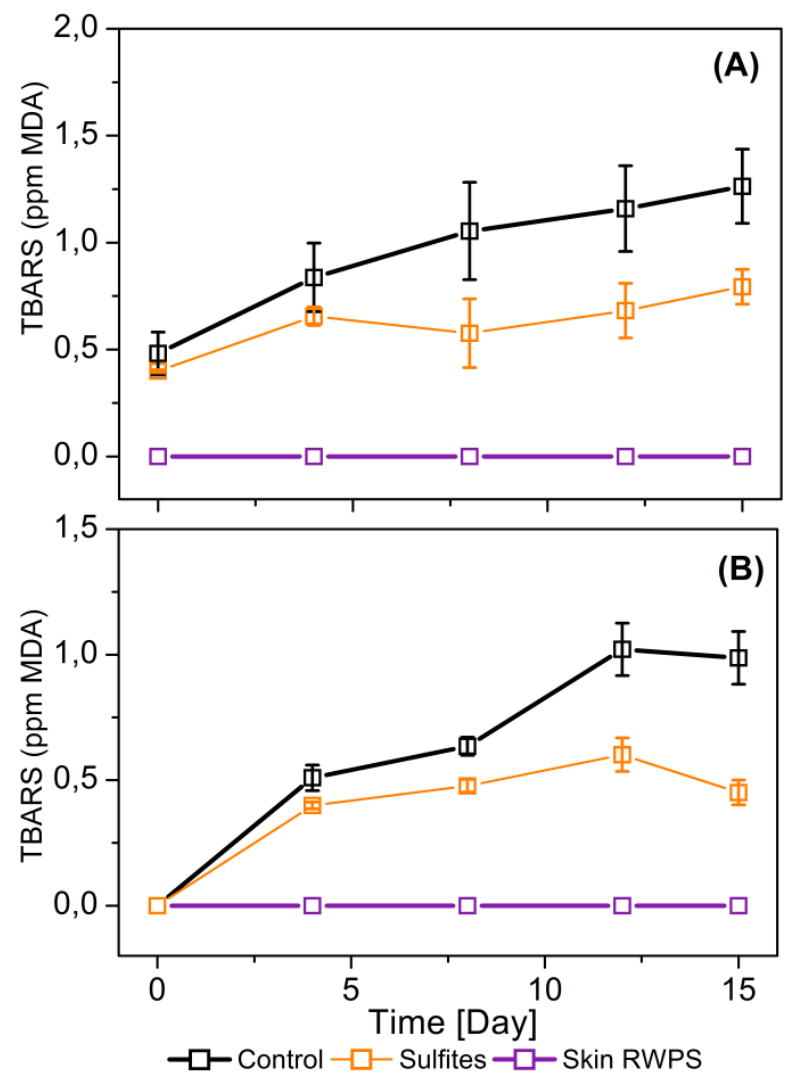

Figure 5.2. Formation of TBARS in beef patties without addition of any antioxidant (Control), with addition red skin wine pomace seasonings (Skin RWPS at 2\% w/w) or sulfites $(300 \mathrm{ppm})$ stored under high-oxygen atmosphere $\left(70 \% \mathrm{O}_{2} / 30 \% \mathrm{CO}_{2}\right)$ for 15 days at $4{ }^{\circ} \mathrm{C}$ in two independent experiments (A and B). Points show mean values of three replicates, and bars indicated standard deviation at each sampling point. 
Besides the information provided by TBARS value, which quantifies those aldehydes (mainly MDA) that react to thiobarbituric acid, other low molecular weight compounds, formed by the breakdown of the fatty acids, are also considered good indices of this process. Among these Volatile Organic Compounds (VOCs), saturated aldehydes and especially hexanal are extensively recognized as indicators of the lipid oxidation. They play a major role in the development of rancid odors, due to their extensive formation and their relatively low threshold (Calkins \& Hodgen, 2007). Other VOCs of interest are alcohols, 2,3-octanedione and 2-pentylfuran which also contribute to the development of rancid off-odors (Calkins \& Hodgen, 2007; Gravador et al., 2015).

Different VOCs were detected in all the patties, although they were mainly present in control patties, and, there was a general increase throughout the storage period (Figures 5.3. and 5.4.). Hexanal content of control samples increased notably throughout the storage and similar results were obtained in the two assays carried out (Figure 5.3). This result indicated an advanced stage of lipid oxidation, in agreement with trends of TBARS values for these samples. These results agree with previous studies reporting high correlations between TBARS values and hexanal formation (Frankel, 1983; Kanner, 1994). In agreement with hexanal levels, significant increases of levels of 1-pentanol, 1-hexanol, 1-octen-3-ol, 2,3-octanedione and 2-pentylfuran were also detected in control samples (Figure 5.4.), corroborating the development of secondary lipid oxidation.

Patties made with sulfites showed lower levels of hexanal and the other analyzed VOCs in comparison to control patties (Figures 5.3. and 5.4.), which is in agreement with the antioxidant activity of this additive (Günther et al., 1997). The antioxidant activity of sulfites is usually linked to their capacity to reduce lipid 
hydroperoxides without producing radicals (Günther et al., 1997). Moreover, reactive oxygen species can also be scavenged by sulfites leading to radical termination processes (Kaneda et al., 1996). It might also involve the reduction of other prooxidants such as $\mathrm{H}_{2} \mathrm{O}_{2}$ and the ability of sulfites to avoid the accumulation of protein radicals that could act as lipid pro-oxidants (Garcia-Lomillo et al., 2016).
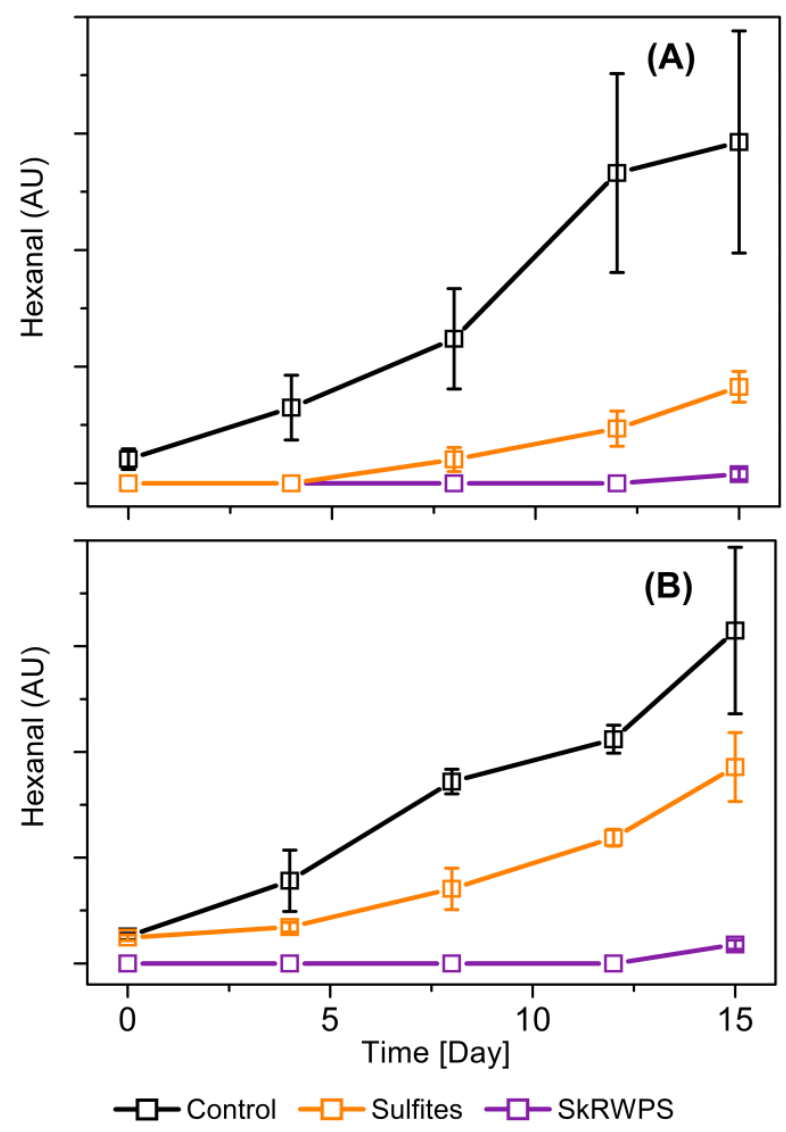

Figure 5.3. Formation of hexanal in beef patties without addition of antioxidants (Control), with the addition of skin red wine pomace seasoning (SkRWPS at 2\% w/w) or with addition of sulfites $(300 \mathrm{ppm})$ stored under high-oxygen atmosphere $(70 \%$ $\mathrm{O}_{2} / 30 \% \mathrm{CO}_{2}$ ) for 15 days at $4{ }^{\circ} \mathrm{C}$ in two independent experiments ( $\mathrm{A}$ and $\mathrm{B}$ ). Results are expressed in Arbitrary Units (AU). Points show mean values of three replicates, and bars indicated standard deviations at each sampling point.

According to TBARS results, SkRWPS patties showed no hexanal except for very low levels at the end of storage. The seasoning was also able to inhibit the formation of 1-octen-3-ol, and to reduce the formation of the other VOCs (Figure 5.4.). 
These results showed higher effectiveness of SkRWPS than sulfites, pointing out the high potential of the new seasoning as an antioxidant in beef patties stored under a high-oxygen atmosphere.

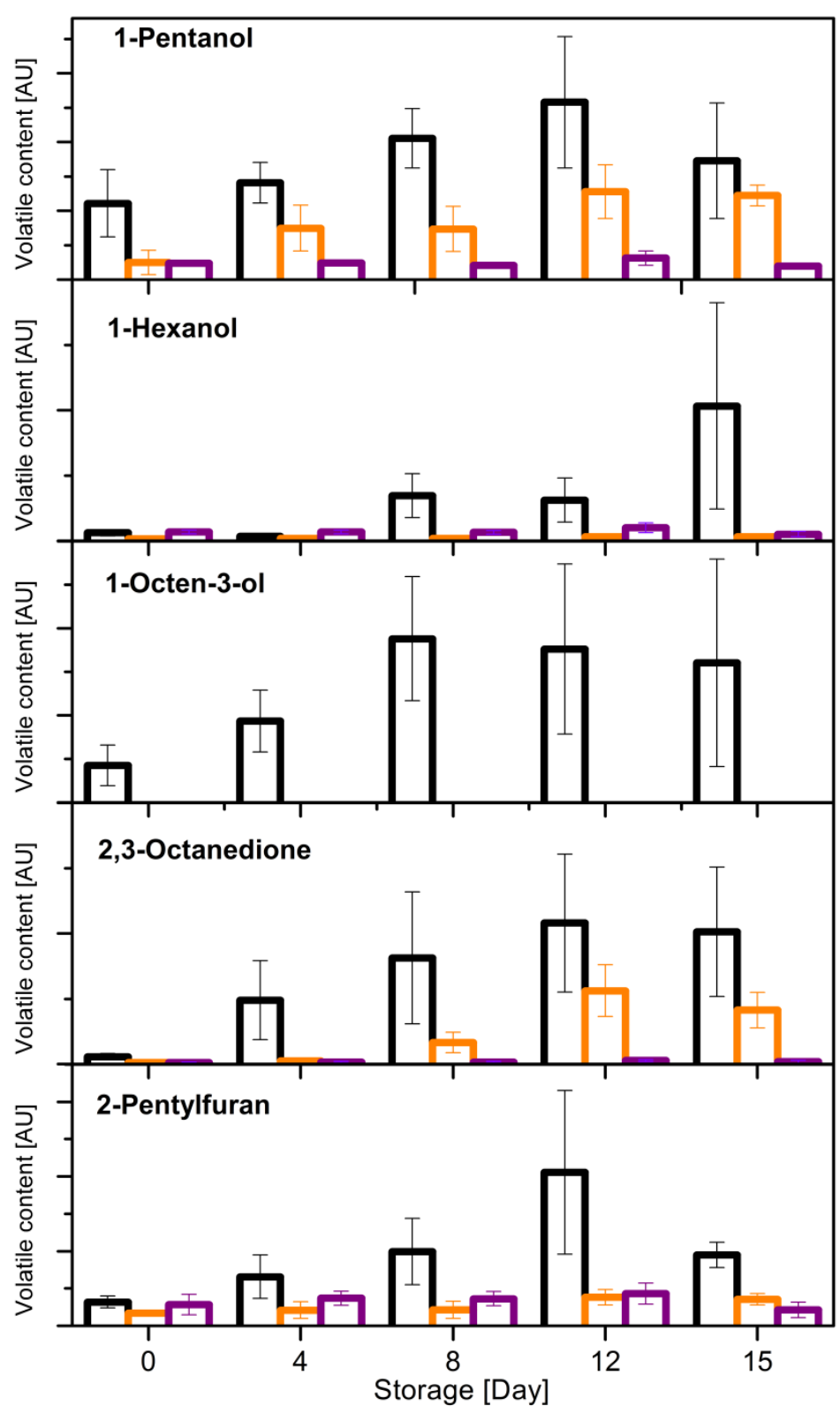

$\square$ Control $\square$ Sulphites $\square$ SkRWPS

Figure 5.4. Formation of five volatile organic compounds: 1-pentanol, 1-hexanol, 1octen-3-ol, 2,3-octanedione and 2-pentylfuran in beef patties without addition of antioxidants (Control), with the addition of skin red wine pomace seasoning (SkRWPS at $2 \% \mathrm{w} / \mathrm{w})$ or with the addition of sulfites (300 ppm) stored under high-oxygen atmosphere $\left(70 \% \mathrm{O}_{2} / 30 \% \mathrm{CO}_{2}\right)$ for 15 days at $4{ }^{\circ} \mathrm{C}$. Results are expressed in Arbitrary Units (AU). Points show mean values of three replicates, and bars indicate standard deviations at each sampling point. 
The obtained results agree with those reported by other authors. Sáyago-Ayerdi et al. (2009) reported that grape antioxidant dietary fiber was capable of inhibiting lipid oxidation in chicken hamburger and Garrido et al. (2011) observed the protective effect of different grape pomace extracts in pork burgers stored under aerobic conditions. Herbs and spices have also reported antioxidant activity in refrigerated meat products (Lindberg Madsen \& Bertelsen, 1995; Yanishlieva et al., 2006). El-Alim et al. (1999) tested different spices observing that the highest inhibition was produced by clove, nutmeg, curry and cinnamon. However, the inhibition was lower than the protection reported for SkRWPS. The protection exerted by SkRWPS was also higher than the antioxidant activity of other spices such rosemary, sage or ground mustard (Lindberg Madsen \& Bertelsen, 1995).

The strong inhibition produced by the seasonings can be ascribed to their high content of phenolic compounds (García-Lomillo et al., 2014). According to Pazos et al. (2005), grape polyphenols present an optimal degree of polymerization and galloylation to delay lipid oxidation in muscle systems. Some authors pointed out the importance of simple extractable compounds such as flavanol monomers, phenolic acids or anthocyanins (Yu \& Ahmedna, 2013). In contrast, Ursini et al. (2001) reported the relevance of polymerized compounds in comparison to their correspondent monomers. Most probably, synergistic reactions between the high content in extractable polyphenols and polymerized proanthocyanidins of the seasoning could explain the observed antioxidant activity (García-Lomillo et al., 2014). The antioxidant mechanisms of polyphenols are usually ascribed to their capacity to donate electrons to free radicals formed during lipid oxidation and to their capacity to stabilize their structure by the resonance delocalization of an electron within their aromatic ring (Brewer, 2011). Moreover, grape phenolics are able to reduce highly-oxidizing ferryl 
species (Kanner et al., 1994) as well as to scavenge superoxide anions (Chen et al., 1990) and hydroxyl radicals (Rafat Husain et al., 1987). Other proposed mechanisms include the chelation of metal initiators and the inhibition of the enzymatic activity of lipoxygenase (Duque et al., 2011).

\subsection{Lipid oxidation under frozen storage of raw and cooked patties}

Meat products stored under different conditions are affected by different oxidative mechanisms and natural antioxidants may show different efficacy in products stored under different storage conditions (Lindberg Madsen \& Bertelsen, 1995). Then, the potential efficacy of the SkRWPS against lipid oxidation was also tested during frozen storage of raw and cooked patties.

TBARS content increased during storage in both the cooked and the raw control samples (Figure 5.5.). At the end of storage, TBARS levels were $0.18 \mathrm{ppm}$ in the raw and $0.08 \mathrm{ppm}$ in the cooked control patties. The observed values were relatively low (ten times lower than in patties stored under refrigeration) indicating only slight lipid oxidation. This fact agrees with the stability of beef, in comparison to other meats, during frozen storage (Igene et al., 1979). The slight formation of TBARS correlated well with the low levels of hexanal that were detected (Figure 5.6.).

The cooked patties showed higher stability against lipid oxidation than the control patties (Figures 5.5. and 5.6.). Although cooking usually produces pro-oxidant effects due to the disruption of cellular organization and the release of iron with catalyst activity (Kanner, 1994). Utrera et al. (2015) also showed lower oxidative stages in cooked samples, ascribing this fact to potential reactions between formed aldehydes and meat proteins. Other authors also hypothesized that Maillard reaction products formed during cooking may have antioxidant effect (Alfawaz et al., 1994). Moreover, 
the inactivation of pro-oxidant enzymes such as lipases could also contribute to the higher stability of cooked rather than raw samples (Kanner, 1994).

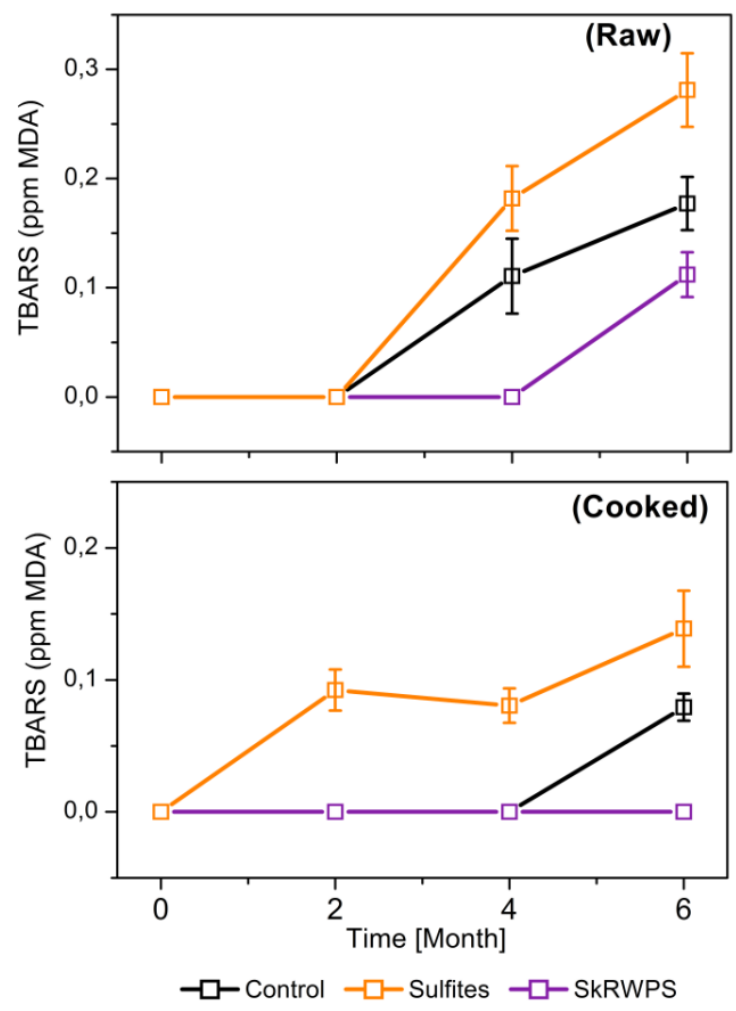

Figure 5.5. Formation of TBARS in raw and cooked beef patties without addition of antioxidants (Control), with the addition of sulfites $\left(300 \mathrm{ppm} \mathrm{SO}_{2}\right)$ or skin red wine pomace seasoning (SkRWPS, $2 \% \mathrm{w} / \mathrm{w}$ ) stored in vacuum packaging for 6 months at $18{ }^{\circ} \mathrm{C}$. Points show mean values of three replicates, and bars indicate standard deviations at each sampling point.

SkRWPS was able to reduce lipid oxidation in both the raw and the cooked frozen patties significantly, which showed lower TBARS and hexanal values than the control samples through the storage (Figures 5.5. and 5.6.). No TBARS were formed in the cooked patties and the raw patties showed a $60 \%$ reduction in comparison to the control patties. The seasoning also inhibited hexanal formation by around $80 \%$ in both types of patties. The formation of other VOCs such as alcohols and ketones was also inhibited by the seasoning (data not shown) in a similar way to hexanal. 

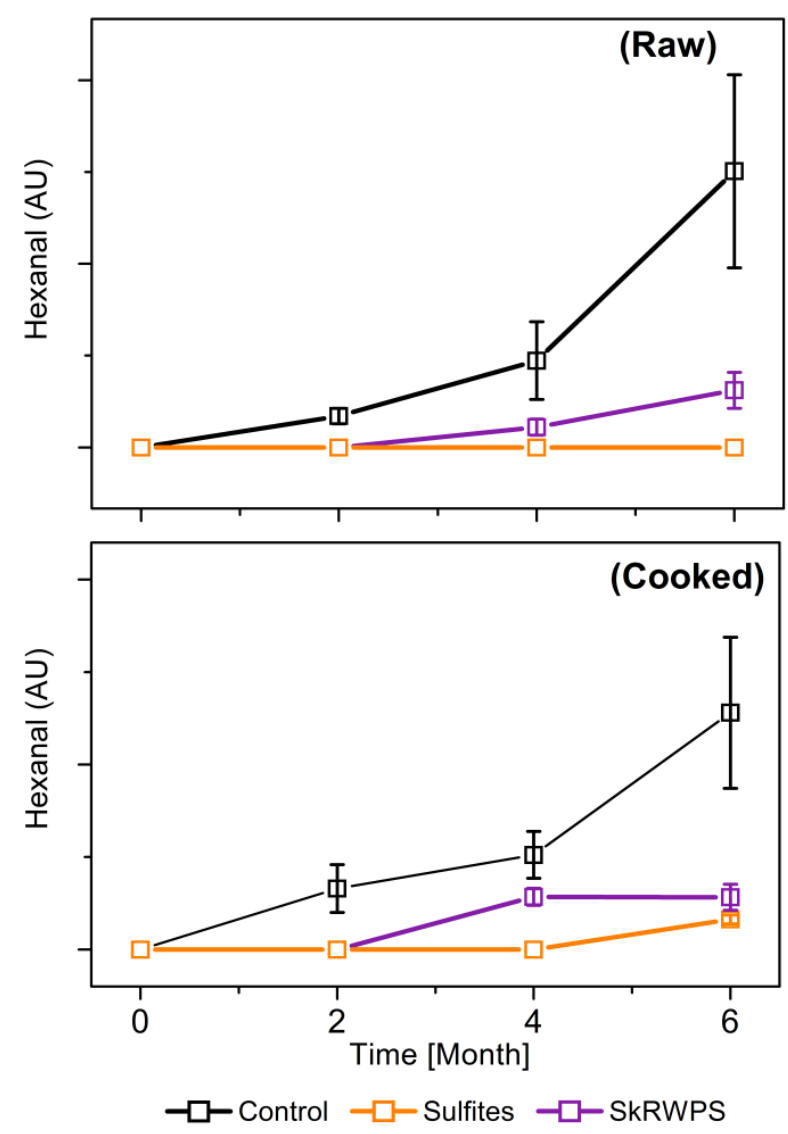

Figure 5.6. Formation of hexanal in raw and cooked beef patties without addition of antioxidants (Control), with the addition of sulfites (300 ppm $\mathrm{SO}_{2}$ ) or skin red wine pomace seasoning (SkRWPS, 2\% w/w) stored in vacuum packaging for 6 months at $18{ }^{\circ} \mathrm{C}$. Results are expressed in Arbitrary Units (AU). Points show mean values of three replicates, and bars indicate standard deviations at each sampling point.

Similar products derived from wine pomace or herbs and spices also showed capacity to inhibit lipid oxidation during frozen storage. For instance, Sánchez-Alonso et al. (2006) found that red grape antioxidant dietary fibre was able to minimize the development of primary and secondary oxidation in minced fish muscle stored at $-20^{\circ}$ C. These authors highlighted the importance of the so-called "non-extractable polyphenols" (NEPP) in the observed antioxidant capacity. Cagdas \& Kumcuoglu (2015) also found that grape seed powder added into the batter inhibited oxidation in precooked chicken nuggets. Wine pomace extracts lowered TBARS values in vacuum 
packaged chicken (Selani et al., 2011). El-Alim et al. (1999) tested different spices at $1 \%$ and found that the most effective spices were marjoram, caraway and rosemary oleoresin preventing TBARS formation in frozen meat products (Lindberg Madsen \& Bertelsen, 1995), but the inhibition was lower than the protection exerted by SkRWPS.

The results observed in patties with sulfites were controversial. Sulfites promoted the formation of TBARS in both cooked and raw hamburgers (Figure 5.5.), which suggests a pro-oxidant activity. However, sulfites successfully delayed the formation of other VOCs derived from lipid oxidation and assessed by GC-MS including hexanal (Figure 5.6.). In this case, their efficacy was even higher than in samples with SkRWPS. The discrepancy between TBARS and VOCs analysis as well as the different behavior of sulfite samples stored under different conditions may be ascribed to diverse factors. In frozen samples, the amount of water decreases in the liquid phase and the solutes (as sulfites) are cryoconcentrated in the liquid phase of water, and may reach pro-oxidant levels (Leygonie et al., 2012). In this regard, sulfites may induce direct intramolecular cleavage of polyunsaturated fatty acids and induce the formation of low molecular weight compounds (Southerland et al., 1982). From among the predominant polyunsaturated fatty acids in beef muscle, sulfites are more likely to attack linolenic acid, (that is MDA precursor) than linoleic acid (whose degradation forms hexanal) (Daley et al., 2010; Southerland et al., 1982). Then, cryoconcentrated sulfites in frozen samples may directly attack double bonds from linolenic leading to MDA formation. The pro-oxidant effect observed in the TBARS analysis could also be explained by conformational changes produced by sulfites in antioxidant enzymes by breaking disulfide bonds inhibiting their activity (Veljovic-Jovanovic et al., 1999). The antioxidant protection provided by these enzymes seems to have a higher relevance on vacuum packaged meat products than in high-oxygen atmosphere (Kang et al., 2014), 
which could explain the observed difference between samples with added sulfites stored in high-oxygen atmosphere and in frozen state. In the case of the cooked samples, sulfites may also inhibit the formation of products derived from Maillard reactions (McWeeny et al., 1969) which may have an antioxidant effect. The chemistry of sulfites in food is rather complex and depends on several factors such as concentration, temperature, matrix effect, etc. (Günther et al., 1997; Kaneda et al., 1996). Further experiments should therefore be conducted for a complete evaluation of the effect of sulfites on lipid oxidation in frozen samples.

\section{CONCLUSIONS}

Taken together, the results of the present study suggest that, from among the three seasonings, the seasoning derived from seedless red wine pomace presented the highest activity. It inhibited the formation of compounds derived from lipid oxidation in patties under different storage conditions. This seasoning also showed higher efficacy than sulfites that showed contradictory results in frozen samples, suggesting a possible pro-oxidant activity.

\section{REFERENCES}

Alfawaz, M., Smith, J. S., \& Jeon, I. J. (1994). Maillard reaction products as antioxidants in pre-cooked ground beef. Food Chemistry, 51(3), 311-318.

Brewer, M. S. (2011). Natural Antioxidants: Sources, Compounds, Mechanisms of Action, and Potential Applications. Comprehensive Reviews in Food Science and Food Safety, 10(4), 221-247.

Cagdas, E., \& Kumcuoglu, S. (2015). Effect of grape seed powder on oxidative stability of precooked chicken nuggets during frozen storage. Journal of Food Science and Technology, 52(5), 2918-2925.

Calkins, C. R., \& Hodgen, J. M. (2007). A fresh look at meat flavor. Meat Science, 77(1), 63-80.

Carpenter, R., O’Grady, M. N., O’Callaghan, Y. C., O’Brien, N. M., \& Kerry, J. P. (2007). Evaluation of the antioxidant potential of grape seed and bearberry extracts in raw and cooked pork. Meat Science, 76(4), 604-610. 
Corcuera Tecedor, E. (2013). Estudio de la aptitud de un aroma natural obtenido a partir de subproductos de buey de mar (Cancer Pagurus) para su aplicación a distintas matrices alimentarias. Universidad de Burgos.

Cornelius, S. O., \& Lilian, W. (2005). Sulfur Dioxide and Sulfites. Antimicrobials in Food, Third Edition, (pp. 143-167): CRC Press.

Chen, Y., Zheng, R., Jia, Z., \& Ju, Y. (1990). Flavonoids as superoxide scavengers and antioxidants. Free Radical Biology \& Medicine, 9(1), 19-21.

Daley, C. A., Abbott, A., Doyle, P. S., Nader, G. A., \& Larson, S. (2010). A review of fatty acid profiles and antioxidant content in grass-fed and grain-fed beef. Nutrition Journal, 9, 10-10.

Duque, A. L., Pinto, M. d. C., \& Macias, P. (2011). Lipoxygenase inhibition by red wine phenolics compounds. Journal of Food Biochemistry, 35(2), 542-555.

El-Alim, S. S. L. A., Lugasi, A., Hóvári, J., \& Dworschák, E. (1999). Culinary herbs inhibit lipid oxidation in raw and cooked minced meat patties during storage. Journal of the Science of Food and Agriculture, 79(2), 277-285.

Frankel, E. N. (1983). Volatile lipid oxidation products. Progress in Lipid Research, 22(1), 1-33.

Garcia-Lomillo, J., González-SanJosé, M., Skibsted, L., \& Jongberg, S. (2016). Effect of Skin Wine Pomace and Sulfite on Protein Oxidation in Beef Patties During High Oxygen Atmosphere Storage. Food and Bioprocess Technology, 9(3), 532-542.

García-Lomillo, J., González-SanJosé, M. L., Del Pino-García, R., Rivero-Pérez, M. D., \& Muñiz-Rodríguez, P. (2014). Antioxidant and antimicrobial properties of wine byproducts and their potential uses in the food industry. Journal of Agricultural and Food Chemistry, 62(52), 12595-12602.

Garrido, M. D., Auqui, M., Martí, N., \& Linares, M. B. (2011). Effect of two different red grape pomace extracts obtained under different extraction systems on meat quality of pork burgers. LWT - Food Science and Technology, 44(10), 22382243.

González-SanJosé, M. L., García-Lomillo, J., Del Pino-García, R., Rivero-Pérez, D., Ortega-Heras, M., \& Muñiz, P. (2014). Seasoning products from wine pomace with interesting preservative and healthful properties. World Buk Wine.

González San José, M. L., García Lomillo, J., Del Pino García, R., Dolores Rivero, M., \& Muñiz Rodríguez, P. (2015). Sazonador de origen vegetal con propiedades conservantes, sustitutivo de la sal, y procedimiento de obtención del mismo. ES2524870 B2. Spain.

Gravador, R. S., Serra, A., Luciano, G., Pennisi, P., Vasta, V., Mele, M., Pauselli, M., $\&$ Priolo, A. (2015). Volatiles in raw and cooked meat from lambs fed olive cake and linseed. Animal, 9(4), 715-722.

Günther, A., König, T., Habicher, W. D., \& Schwetlick, K. (1997). Antioxidant action of organic sulphites-I. Esters of sulphurous acid as secondary antioxidants. Polymer Degradation and Stability, 55(2), 209-216. 
Igene, J. O., Pearson, A. M., Merkel, R. A., \& Coleman, T. H. (1979). Effect of Frozen Storage Time, Cooking and Holding Temperature upon Extractable Lipids and TBA Values of Beef and Chicken. Journal of Animal Science, 49(3), 701-707.

Kaneda, H., Takashio, M., Osawa, T., Kawakishi, S., \& Tamaki, T. (1996). Behavior of sulfites during fermentation and storage of beer. Journal of the American Society of Brewing Chemists, 54(2), 115-120.

Kang, S. M., Kang, G., Seong, P. N., Park, B., \& Cho, S. (2014). Evaluation of various packaging systems on the activity of antioxidant enzyme, and oxidation and color stabilities in sliced hanwoo (Korean Cattle) Beef loin during chill storage. Asian-Australasian Journal of Animal Sciences, 27(9), 1336-1344.

Kanner, J. (1994). Oxidative processes in meat and meat products: Quality implications. Meat Science, 36(1-2), 169-189.

Kanner, J., Frankel, E., Granit, R., German, B., \& Kinsella, J. E. (1994). Natural antioxidants in grapes and wines. Journal of Agricultural and Food Chemistry, 42(1), 64-69.

Leygonie, C., Britz, T. J., \& Hoffman, L. C. (2012). Impact of freezing and thawing on the quality of meat: Review. Meat Science, 91(2), 93-98.

Lindberg Madsen, H., \& Bertelsen, G. (1995). Spices as antioxidants. Trends in Food Science \& Technology, 6(8), 271-277.

McWeeny, D. J., Biltcliffe, D. O., Powell, R. C. T., \& Spark, A. A. (1969). The Maillard Reaction and its Inhibition by Sulfite. Journal of Food Science, 34(6), 641-643.

Pazos, M., Gallardo, J. M., Torres, J. L., \& Medina, I. (2005). Activity of grape polyphenols as inhibitors of the oxidation of fish lipids and frozen fish muscle. Food Chemistry, 92(3), 547-557.

Rafat Husain, S., Cillard, J., \& Cillard, P. (1987). Hydroxyl radical scavenging activity of flavonoids. Phytochemistry, 26(9), 2489-2491.

Sánchez-Alonso, I., Jiménez-Escrig, A., Saura-Calixto, F., \& Borderías, A. J. (2006). Effect of grape antioxidant dietary fibre on the prevention of lipid oxidation in minced fish: Evaluation by different methodologies. Food Chemistry, 101(1), 372-378.

Sarabia, L., \& Ortiz, M. C. (1994). DETARCHI: A program for detection limits with specified assurance probabilities and characteristic curves of detection. TrAC Trends in Analytical Chemistry, 13(1), 1-6.

Sáyago-Ayerdi, S. G., Brenes, A., \& Goñi, I. (2009). Effect of grape antioxidant dietary fiber on the lipid oxidation of raw and cooked chicken hamburgers. $L W T$ - Food Science and Technology, 42(5), 971-976.

Selani, M. M., Contreras-Castillo, C. J., Shirahigue, L. D., Gallo, C. R., Plata-Oviedo, M., \& Montes-Villanueva, N. D. (2011). Wine industry residues extracts as natural antioxidants in raw and cooked chicken meat during frozen storage. Meat Science, 88(3), 397-403. 
Southerland, W. M., Akogyeram, C. O., Toghrol, F., Sloan, L., \& Scherrer, R. (1982). Interaction of bisulfite with unsaturated fatty acids. Journal of Toxicology and Environmental Health, 10(3), 479-491.

Tarladgis, B., Watts, B., Younathan, M., \& Dugan, L., Jr. (1960). A distillation method for the quantitative determination of malonaldehyde in rancid foods. Journal of the American Oil Chemists Society, 37(1), 44-48.

Ursini, F., Rapuzzi, I., Toniolo, R., Tubaro, F., \& Bontempelli, G. (2001). Characterization of antioxidant effect of procyanidins. P. Lester (Ed.), Methods in Enzymology, vol. Volume 335 (pp. 338-350): Academic Press.

Utrera, M., Morcuende, D., Ganhão, R., \& Estévez, M. (2015). Role of Phenolics Extracting from Rosa canina L. on Meat Protein Oxidation During Frozen Storage and Beef Patties Processing. Food and Bioprocess Technology, 8(4), 854-864.

Veljovic-Jovanovic, S., Milovanovic, L., Oniki, T., \& Takahama, U. (1999). Inhibition of catalase by sulfite and oxidation of sulfite by $\mathrm{H} 2 \mathrm{O} 2$ cooperating with ascorbic acid. Free Radical Research, 31(SUPPL.), S51-S57.

Yanishlieva, N. V., Marinova, E., \& Pokorný, J. (2006). Natural antioxidants from herbs and spices. European Journal of Lipid Science and Technology, 108(9), 776-793.

Yu, J., \& Ahmedna, M. (2013). Functional components of grape pomace: their composition, biological properties and potential applications. International Journal of Food Science \& Technology, 48(2), 221-237.

Zhao, Y., Wells, J. H., \& McMillin, K. W. (1994). Applications of dynamic modified atmosphere packaging systems for fresh red meats: Review. Journal of Muscle Foods, 5(3), 299-328. 


\section{CHAPTER 6:}

\section{EFfect of Skin Wine Pomace ANd Sulfite on Protein Oxidation in BeEF PatTies}

During High OXygen AtMosphere Storage 



\section{Presentación}

Los procesos de degradación oxidativa de las proteínas han sido menos frecuentemente estudiados en alimentos que los de la fracción lipídica. No obstante, estos procesos también pueden afectar la calidad de los alimentos ya que alteran las propiedades sensoriales y nutricionales de los mismos.

Este capítulo se centra en la evaluación de la capacidad protectora frente a la oxidación proteica de dos productos obtenidos a partir de orujos, comparándolo con el efecto protector de los sulfitos. En este estudio, la actividad antioxidante del producto más eficaz en estudios previos, el derivado de orujo tinto libre de pepitas, se comparó con un producto similar elaborado desde orujos de uva blanca, aplicados en hamburguesas conservadas en atmósfera modificada. La razón de esta comparación fue el interés mostrado en este segundo producto por el equipo de investigación danés con el que el trabajo se desarrolló en colaboración.

\section{Resultados más relevantes}

Sólo el producto procedente del orujo tinto, así como los sulfitos, redujeron la formación de radicales de la fracción proteica. Los tres productos inhibieron el entrecruzamiento de la miosina. Por otra parte, la incorporación de los productos derivados de los orujos produjo un descenso instantáneo de los niveles de grupos tioles conduciendo a la formación de nuevas bandas proteicas. Por tanto, aunque los productos en estudio fueron capaces de inhibir algunas de las reacciones relacionadas con la oxidación de las proteínas no fueron tan eficaces como los sulfitos. 



\title{
Chapter 6: Effect of Skin Wine Pomace and Sulfite on Protein
}

\section{Oxidation in Beef Patties During High Oxygen Atmosphere Storage}

\begin{abstract}
Meat storage in high oxygen atmosphere has been reported to induce protein oxidation reactions decreasing meat quality. The incorporation of antioxidants has been proposed to reduce the extent of these reactions. In this study, the ability of red and white skin wine pomaces as well as sulfites to inhibit protein oxidation were tested in beef patties stored for up to 15 days at $4{ }^{\circ} \mathrm{C}$ in a high oxygen atmosphere $\left(70 \% \mathrm{O}_{2}\right.$ and $\left.30 \% \mathrm{CO}_{2}\right) . \mathrm{SO}_{2}(300 \mathrm{ppm})$ effectively protected against protein oxidation measured as radical formation by electron spin resonance (ESR) spectroscopy, as thiol loss by the DTNB assay, and as myosin heavy chain (MHC) disulfide cross-linking by SDSPAGE. Pomace from red wine production with total phenol of $9.9 \mathrm{mg}$ gallic acid equivalent/g protected against protein radical formation and against MHC crosslinking, but not against thiol loss by addition of $2.0 \%(\mathrm{w} / \mathrm{w})$ to the beef patties. Pomace from white wine production with total phenol of $4.0 \mathrm{mg}$ gallic acid equivalents/g only protected against MHC cross-linking. For both types of wine pomace, protein modifications not seen for sulfite addition were observed and were proposed to involve covalent phenol addition to proteins. Red wine pomace may be an alternative to sulfite as a meat additive for protection of beef patties against protein oxidation.
\end{abstract}
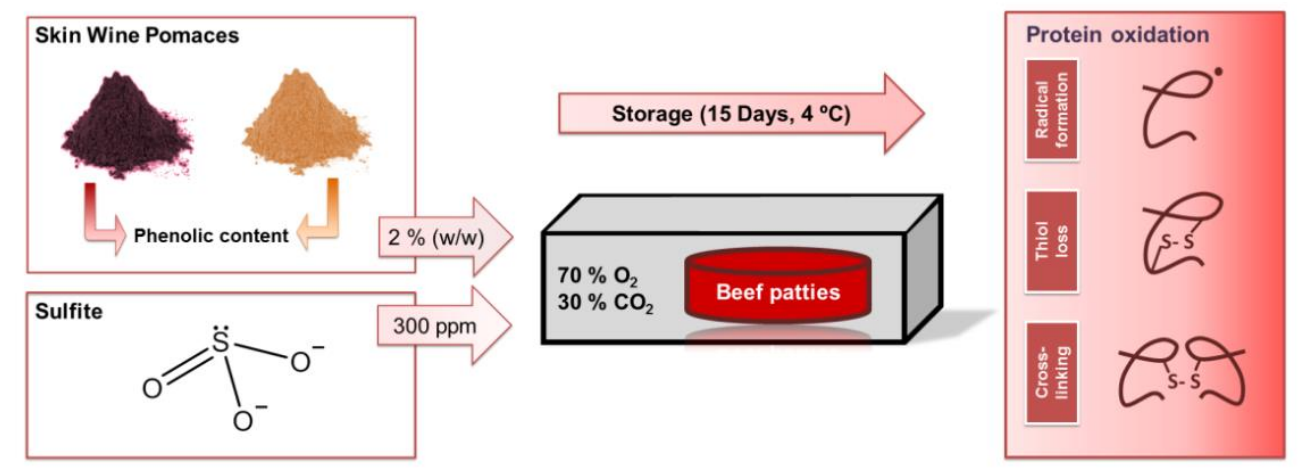

Published in Food and Bioprocess Technology, March 2016, Volume 9, Issue 3, pp 532-542. DOI: 10.1007/s11947-015-1649-y 


\section{INTRODUCTION}

Protein oxidation has recently attracted attention due to its consequences on protein solubility and functionality. Protein oxidation is accelerated by technological aspects such as high-oxygen modified atmosphere packaging (HiOx MAP), salting or exposure to light (Benjakul et al., 2012; Fu et al., 2015; Jongberg et al., 2014). As a consequence of protein oxidation, meat sensory properties are deteriorated, essential amino acids may be lost, and protein digestibility may decrease (Xiong, 2000). These protein alterations are detrimental to the overall quality of fresh meat and meat products. In biological matrices such as meat, protein oxidation progresses via free radical chain reactions, initiated by reactive oxygen species generating protein radicals, which in turn may undergo different reactions resulting in formation of carbonyl derivatives, loss of thiol groups, and formation of protein cross-links. All reactions are widely used to evaluate the effect on meat quality (Lund et al., 2011).

Meat and meat products are basic components of Western diets and are excellent sources of proteins, vitamins or iron. However, the link between consumption of meat and meat products and some prevalent diseases such as cardiovascular disease, cancer, hypertension or obesity has affected consumers`' opinion about meat negatively (Jiménez-Colmenero et al., 2001). Consequently, the meat industry is seeking new alternatives in order to produce healthier meat products such as the replacement of artificial additives by natural plant extracts (Brewer, 2011; Serrano \& Bañón, 2012), improving their fatty acid profile (Martínez et al., 2012) or fortifying the dietary fiber content (Martínez et al., 2011).

Natural plant extracts have been found to be effective antioxidants reducing the oxidation of meat and meat products (Brewer, 2011). Previous studies show that numerous of these plant extracts can inhibit or, at least delay lipid oxidation in meat 
products. However, the results reported on protein oxidation are more ambiguous. Jongberg et al. (2011b) showed that white grape extract was able to inhibit the formation of disulfide protein cross-links, but accelerated the loss of protein thiols. Nieto et al. (2013) found that the addition of oregano and rosemary essential oils to pork patties protected both against thiol loss and cross link formation. On the other hand, in the same study a prooxidative effect of garlic essential oil resulted in the complete depletion of protein thiols. Further, clear prooxidant activity was found by addition of aqueous potato peel extracts to minced horse mackerel, which increased the loss of tyrosine and tryptophan as measured by fluorescence spectroscopy (Sabeena Farvin et al., 2012). In contrast, significant reduction of carbonyl formation was found for addition of certain fruit and pine bark extracts to cooked porcine patties prior to cooking (Ganhão et al., 2010; Vuorela et al., 2005).

Wine pomace is a solid by-product generated in large quantities during the winemaking process after grape fermentation that contains mainly grape skin and grape seeds. Wineries have traditionally needed to handle and dispose this residue, incurring in new costs. However, it can be reutilized by the food industry because it still contains a wide range of interesting compounds such as dietary fiber, polyphenols, and minerals (García-Lomillo et al., 2014). Several studies have reported positive effects of increased fiber and antioxidant contents in bakery products (Mildner-Szkudlarz et al., 2011) resulting from the incorporation of processed wine pomace. Other studies have documented the ability of wine pomace to limit lipid oxidation in different fat systems (García-Lomillo et al., 2014), in yoghurt and in salad dressing (Tseng \& Zhao, 2013). The high content in bioactive compounds and the antioxidant activity suggest that wine pomace could effectively inhibit the oxidative processes affecting meat protein. 
In southern European countries, sulfites are used to extend the shelf life of burger patties. The European Commission ("Council Directive $\mathrm{N}^{\circ}$ 95/2/EC of 20 February 1995 on food additives other than colours and sweeteners," 1995) allows the incorporation of different sources of sulfur dioxide into products labeled as "burger meat". Sulfite is commonly used in agreement with this directive in burger meat in the Spanish meat industry due to its ability to delay the microbial spoilage and discoloration resulting from myoglobin oxidation (Serrano \& Bañón, 2012). Although sulfites possess exceptional good technological properties, the allergic and respiratory reactions resulting from exposure to sulfites, especially for sensitive individuals (Vally \& Misso, 2012), have led the meat industry to search for alternatives to sulfites, to extend the shelf-life of this type of products.

In the present study, the protective effects against protein oxidation in beef patties stored for 15 days in $\mathrm{HiOx}$ MAP of red and white skin wine pomaces were compared to the protective effect of sulfite. The progression of the protein oxidation was evaluated by the formation of protein radicals, loss of protein thiols, and the degree of protein cross-linking.

\section{MATERIALS AND METHODS}

\subsection{Reagents}

Reagent-grade chemicals and distilled-deionized (Milli-Q Plus, Millipore Coorporation, Bedford, MA) water were used throughout.

\subsection{Preparation of wine pomace products}

Red wine pomace was obtained from a selection of wineries situated in Burgos (Spain). White wine pomace was produced in the pilot plant at University of Burgos by fermentation of white grapes, obtained from different wineries situated in Burgos 
(Pérez-Magariño \& González-San José, 2001). At the end of the alcoholic fermentation (reducing sugar content lower than $2 \mathrm{~g} / \mathrm{l}$ ), white wine pomace was separated from liquids by draining and pressing.

Wine pomaces were dried in a conventional oven (P-Selecta, Barcelona, Spain) during $4-4.5$ hours at a temperature lower than $60{ }^{\circ} \mathrm{C}$. After dehydration, seeds were removed and the products obtained were milled using a grinder (Ascaso, Barcelona, Spain), and sieved to obtain a skin wine pomace product (SkWPP) with particles smaller than $0.25 \mathrm{~mm}$. In order to assure microbial safety, SkWPP were subjected to thermal processing $\left(90^{\circ} \mathrm{C}\right.$ for 90 minutes) in a conventional oven before storage in opaque packages at room temperature until patty preparation. Further details regarding the preparation of wine pomace products and their characterization are described in a previous work (García-Lomillo et al., 2014).

\subsection{Preparation, packaging, and storage of beef patties}

Beef meat (65.5\% water, $16.5 \%$ protein, $13.4 \%$ fat) was purchased from a local supplier, chopped, ground using a food mincer (Cato, Sabadell, Spain), and divided in four portions. In the control formulation, the ingredients per kilogram of burger patty were as follow: $920 \mathrm{~g}$ of meat, $50 \mathrm{~mL}$ of water, $15 \mathrm{~g}$ of sodium chloride, $12 \mathrm{~g}$ of potato starch, and $3.0 \mathrm{~g}$ of a commercially available mix of food grade phosphates (Doscadesa, Murcia, Spain). In the samples added sulfite, water was replaced by $50 \mathrm{~mL}$ of an aqueous solution of sodium metabisulfite $\left(\mathrm{Na}_{2} \mathrm{~S}_{2} \mathrm{O}_{5}\right)$ to obtain a final concentration of $300 \mathrm{mg}$ of $\mathrm{SO}_{2}$ per $\mathrm{kg}$ of burger $(300 \mathrm{ppm})$ in agreement with the Council Directive 95/2/EC. In the case of red and white grape pomace, water was replaced by a suspension in water of the red or white SkWPP to obtain a final concentration of $20 \mathrm{~g}$ of SkWPP per kg of burger $(2 \% \mathrm{w} / \mathrm{w})$. The level of SkWPP was based on preliminary experiments including a sensory analysis, and the same levels 
were found to reduce lipid oxidation in a previous study (García-Lomillo et al., 2014). The meat was processed using a food mixer (Cato) for 5 minutes, and patties of 100 grams were formed by hand before packaging in trays of polyethylene/ethylene vinyl alcohol/polystyrene (PE/EVOH/PS) (Sanviplast, Barcelona, Spain) with a permeability to oxygen of $0.99 \mathrm{~cm}^{3} /\left(\mathrm{m}^{2}\right.$ day atm). They were then sealed using a polyethylene terephthalate polyvinylidene chloride/polyethylene (PETPVdC/PE) film with an oxygen permeability of $7 \mathrm{~cm}^{3} /\left(\mathrm{m}^{2}\right.$ day atm) (Amcor, Burgos, Spain) and using a gas mixer (WITT-Gasetechnik GmbH \& Co KG, Witten, Germany). Samples were stored at $4^{\circ} \mathrm{C}$ for up to 15 days. One sample refers to two beef patties packaged together in one tray, and three trays of each sample were prepared resulting in three replicates of each sample for each time point, days $4,8,12$ and 15 . On the day of collection, the two patties were mixed and a portion of $10 \mathrm{~g}$ were collected and stored in vacuum at $-80{ }^{\circ} \mathrm{C}$ until preparation of myofibrillar protein isolates (MPI).

\subsection{Extractable phenol contents of SkWPP}

Two grams of SkWPP and $25 \mathrm{~mL}$ of methanol: formic acid (97:3) were left for extraction at room temperature for 24 hours and solid residues were removed by filtration. Total polyphenol content (TPC), total catechin content (TCC), total anthocyanin content (TAC) and total proanthocyanidin content (TPAC) were measured according the methods described by Barceló (1990). Briefly, TPC was determined by reaction with Folin-Ciocalteu reagent, and were expressed as mg/g of gallic acid. TCC was determined by the spectrophotometric vanillin method, and expressed as $\mathrm{mg} / \mathrm{g}$ of D-catechin. TAC was quantified by measuring the absorbance at $525 \mathrm{~nm}$ of $1 \mathrm{~mL}$ of extract diluted in $10 \mathrm{~mL}$ of $1 \mathrm{~N} \mathrm{HCl}$, using $1 \mathrm{~mL}$ of the extract diluted in $10 \mathrm{~mL}$ of citrate phosphate buffer $\mathrm{pH} 3.5$ as a blank, and expressed as mg/g of malvidin-3- 
glucoside. TPAC was determined from the increase of absorbance at $550 \mathrm{~nm}$ after acid hydrolysis at $95^{\circ} \mathrm{C}$ for 40 minutes, and expressed as $\mathrm{mg} / \mathrm{g}$ of proanthocyanidin $\mathrm{B} 1$.

\subsection{Isolation of myofibrillar proteins}

The myofibrillar protein fractions were isolated from beef patties according to the method described by Jongberg et al. (2011a). The MPI were lyophilized and stored at $-20{ }^{\circ} \mathrm{C}$ until analysis.

\subsection{Protein radicals by ESR spectroscopy}

The formation of protein radical was assessed according to the method proposed by Jongberg et al. (2013). Pulverized lyophilized MPI were transferred to quartz electron spin resonance $(\mathrm{ESR})$ tubes $($ inner diameter $=4 \mathrm{~mm}$, wall $=0.5 \mathrm{~mm}$; Wilmad, Buena, NJ) to a height of $1 \mathrm{~cm}$ in the tube. The tubes were placed in the cavity of a JEOL JES-FR30X ESR spectrometer (JEOL Ltd., Tokyo, Japan) with the following settings: microwave power, $4 \mathrm{mV}$; center field, $336 \mathrm{mT}$; sweep width, $5 \mathrm{mT}$; sweep time, 2 min; modulation width, $0.125 \mathrm{mT}$; amplitude, 200; time constant, $0.1 \mathrm{~s}$; accumulations, 1 . The radical signal intensity of the ESR spectra were determined as follows:

$$
\text { Peak height } \cdot(\text { peak width })^{2} / \text { Sigr }
$$

$$
\text { Radical intensity }=\frac{\text { Weight of sample }(g)}{\text { Weigh }}
$$

where the peak width is the peak-to-peak width in the ESR spectrum. Data are presented as mean \pm SD of three replicates. Spectral manipulation using SavitzkyGolay signal processing (400 points were considered during the smoothing routine) was applied for the presentation of selected ESR spectra. 


\subsection{Protein thiol groups}

Protein thiol groups were quantified after derivatisation with 5,5 dithiobis (2nitrobenzoic acid) (DTNB) as recently described by Jongberg et al. (2014) though downscaled to use only $167 \mu \mathrm{L}$ supernatant compared to $500 \mu \mathrm{L}$ in the original method. The thiol concentrations in $\mathrm{nmol}$ thiol/mg protein are presented as means $\pm \mathrm{SD}$ of three independent replicates.

Any potential interference caused by the presence of remaining sulfites and SkWPP in the DNTB assay was tested. Initially, free sulfite concentration was evaluated by dissolving $10 \mathrm{mg}$ of MPI originating from patties added sulfite in $1 \mathrm{~mL}$ of 0.10 M TRIS buffer ( $\mathrm{pH} 8.0$ ) for one hour in an $80{ }^{\circ} \mathrm{C}$ water bath. Insoluble parts were removed by centrifugation and filtration and the supernatant was analyzed for sulfite content by derivatization with ThioGlo 1 and subsequent reversed-phase highperformance liquid chromatography (RP-HPLC) separation of the fluorescent adducts (Abrahamsson et al., 2012). Moreover, the interference from SkWPP was tested in a sample containing $10 \mathrm{mg}$ of MPI originating from patties added red SkWPP. Further, the amount of red or white SkWPP in the MPI was estimated by spectrophotometric measurement of pure SkWPP compared with MPI containing SkWPP. Thus, a sample containing $0.57 \mathrm{mg}$ red SkWPP and a sample containing $0.69 \mathrm{mg}$ white SkWPP was prepared. All three samples (MPI $\mathrm{SkWPP}_{\mathrm{S}}$, red SkWPP, and white SkWPP) were dissolved in $1 \mathrm{~mL} 5.0 \%$ SDS in $0.10 \mathrm{M}$ TRIS buffer ( $\mathrm{pH} 8.0$ ) for one hour in an $80{ }^{\circ} \mathrm{C}$ water bath, centrifuged and filtrated. An aliquot of $167 \mu \mathrm{L}$ of each filtrate was added to the reaction mixture of L-cysteine and DTNB before or after the 30 minutes reaction time.

\subsection{SDS-PAGE for analysis of protein cross-linking}

Lyophilized MPIs ( $1 \mu \mathrm{g}$ protein per well) were analyzed by gel-electrophoresis using NuPAGE Novex 3-8 \% TRIS-acetate gels according to the manufacturer's 
instructions (Invitrogen, Carlsbad, CA) as described previously by Jongberg et al. (2014). The gels were scanned with a Thypoon scanner (GE Healthcare, Freiburg, Germany) and the volume of the observed bands was determined after subtraction of background, using Phoretix 1D software, version 2003.02. Percent volume of myosin heavy chain (MHC) and cross-linked myosin heavy chain (CL-MHC) was calculated as follows:

$$
\% \text { volume }=\frac{\text { Volume of the studied band }}{\text { Sum of volume of all bands in the same lane }} * 100
$$

\subsection{Statistical analysis}

Statistical analysis was performed using StatGraphics ${ }^{\circledR}$ Centurion XVI. Shapiro-Wilk tests were conducted to check the normal distribution of results with $95 \%$ confidence level. Fisher's least significant difference test was performed in order to identify significant differences between different formulations and at different days of storage with $95 \%$ confidence level.

\section{RESULTS AND DISCUSSION}

\subsection{Extractable phenol contents of SkWPP}

Results showed that red skin wine pomace product (SkWPP) contained more than two times the concentration of TPC $(9.86 \pm 0.24 \mathrm{mg}$ gallic acid/g) as compared to the white SkWPP $(3.97 \pm 0.03 \mathrm{mg}$ gallic acid/g). As expected, anthocyanins were only present in red SkWPP $(1.23 \pm 0.04 \mathrm{mg}$ malvidin-3-glucoside/g). Anthocyanins are the characteristic pigments of red grapes and they are the main phenols in red grape skin (Pinelo et al., 2006). In contrast, levels of extractable catechins were similar in both white $(2.10 \pm 0.01 \mathrm{mg}$ D-catechin/g) and red SkWPP $(2.44 \pm 0.15 \mathrm{mg}$ D-catechin/g). Proanthocyanidins are oligomers of catechins and they are usually synthesized in higher quantities in red than in white grapes (Pinelo et al., 2006), and accordingly red 
SkWPP was found to have a higher content of proanthocyanidins $(14.82 \pm 0.50 \mathrm{mg}$ proanthocyanidin B1/g) than white $\operatorname{SkWPP}(8.23 \pm 0.20 \mathrm{mg}$ proanthocyanidin $\mathrm{B} 1 / \mathrm{g})$. Catechins and specially proanthocyanidins are usually found to be highly reactive towards proteins (McManus et al., 1985).

\subsection{Protein radical formation}

The electron spin resonance (ESR) spectra of myofibrillar protein isolates (MPI) from beef stored for 15 days in HiOX MAP indicates that the lowest accumulation of protein radicals had occurred in the patties added sulfites (Figure 6.1., left panel). In contrast, addition of white SkWPP to the beef patties resulted in higher radical intensity, whereas addition of red SkWPP was not found to affect the protein radical intensity in the beef patties after 15 days of storage as compared to the control (Figure 6.1., left panel). In order to evaluate whether the observed ESR signals from the different samples were due to similar type of radicals, the ESR spectra were compared after augmentation, meaning that the sample added sulfites spectra was amplified to the size of the control, followed by comparison of the two spectra shapes (Figure 6.1., right panel). The shape of ESR spectra from beef patties added sulfites did not deviate from the shape of the control spectrum, indicating that the radical species formed were of similar nature (Figure 6.1., right panel, A). In the case of the samples containing red and white SkWPP, the peak-to-peak width was narrower in comparison to the control (Figure 6.1., right panel, B) indicating that the radical species may deviate from the radicals generated in the control beef patties. It is expected that the water soluble free phenolic compounds are removed during the MPI isolation process. Consequently, the difference in the shape of the spectra is caused by the formation of other types of radicals incorporated into the protein structure. Jongberg et al. (2013) ascribed these changes in the spectra to the formation of protein-bound phenoxyl radicals, formed 
subsequently to covalent protein-phenol interactions. No relevant differences in the radical spectra were observed between MPI from samples containing red or white SkWPP, which suggests that the radicals are of similar nature in the two types of samples (Figure 6.1., right panel, C).
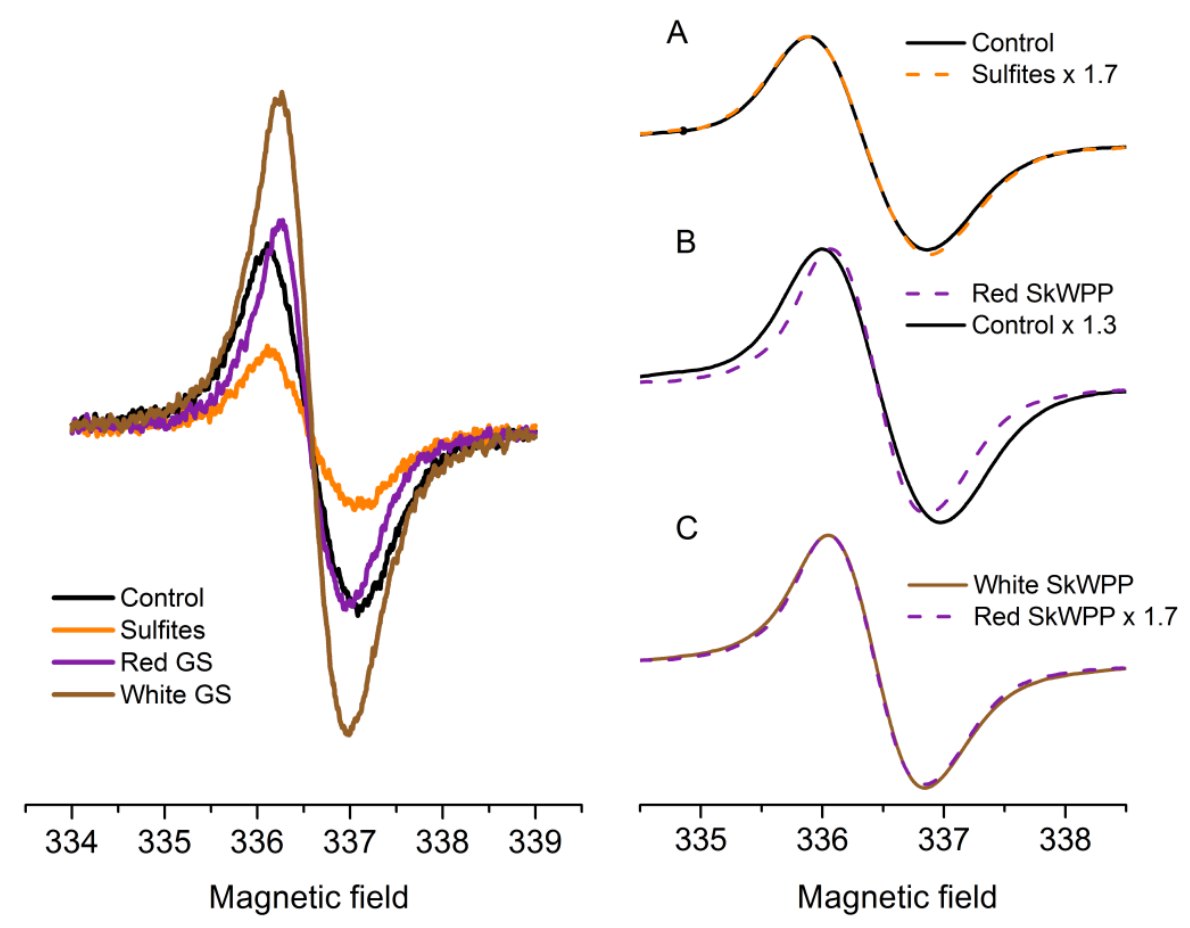

Figure 6.1. ESR spectra of myofibrillar protein isolates (MPI) extracted from beef patties without addition of any antioxidant (Control) or with addition of sulfites (300 ppm $\mathrm{SO}_{2}$ ), red or white skin wine pomace product (SkWPP, $2 \% \mathrm{w} / \mathrm{w}$ ) stored in highoxygen atmosphere for 15 days at $4{ }^{\circ} \mathrm{C}$. Left panel: representative ESR spectra obtained from freeze dried myofibrillar protein isolate. Right panel: ESR spectrum of MPI from A) control beef patties compared to patties added sulfites (spectra amplified by 1.7). B) beef patties added red SkWPP compared to control beef patties (spectra amplified by 1.3). C) beef patties added white SkWPP compared to beef patties added red SkWPP (spectra amplified by 1.7).

The protein radical intensity was quantified during storage time, and it was found that the radical intensity of the control patties and in those containing white SkWPP increased during storage (Figure 6.2.). Radical accumulation may cause undesirable changes in the structure, functionality and digestibility of meat protein, decreasing the overall quality of meat products (Nissen et al., 2000; Xiong, 2000). 
Contrary, no significant increase over time was found in MPI from beef patties added sulfites or red SkWPP. The observed difference between red and white SkWPP may be explained by the higher phenolic content of red SkWPP in proanthocyanidins and anthocyanins. Grape anthocyanins are water-soluble and well-known radical scavengers due to their more complete conjugated structure, which better allows electron delocalization and formation of very stable radicals (Rivero-Pérez et al., 2008). In the present study, water-soluble compounds, including possible anthocyanins, are most likely removed during the MPI isolation process, and this may explain the reduced radical intensity in the MPI from the beef patties added red SkWPP.

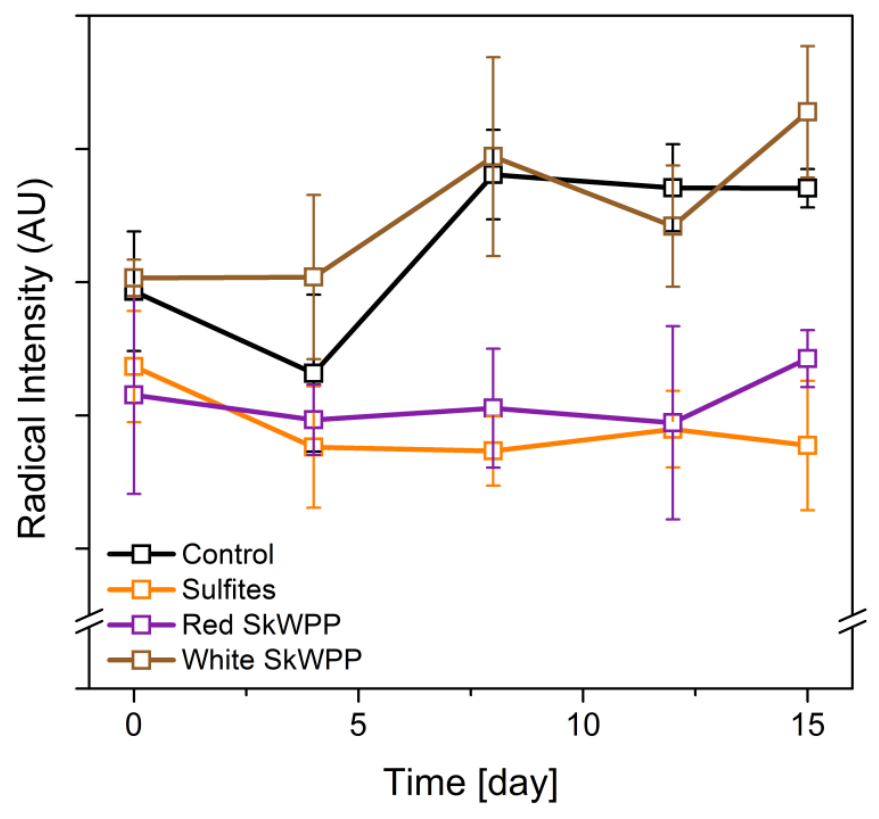

Figure 6.2. Protein radical intensity (mean $\pm \mathrm{SD}, \mathrm{n}=3$ ) of myofibrillar protein isolates (MPI) extracted from beef patties without addition of any antioxidant (Control), with addition of sulfites (300 $\mathrm{ppm} \mathrm{SO}_{2}$ ), or with addition of red or white skin wine pomace product (SkWPP, $2 \% \mathrm{w} / \mathrm{w}$ ) stored for 15 days in high-oxygen atmosphere at $4{ }^{\circ} \mathrm{C}$ as determined by ESR spectroscopy.

Sulfite was also able to inhibit the formation of protein radicals throughout storage. There are several plausible pathways which may explain this protective effect. Sulfites are able to remove $\mathrm{H}_{2} \mathrm{O}_{2}$ (McFeeters, 1998) (eq. 1), which otherwise is a 
common source of highly reactive radicals in meat due to its participation in the pseudo-peroxidase cycle of myoglobin (Davies, 1990) and in the Fenton reaction (Stadtman, 1990).

$$
\mathrm{HSO}_{3}^{-}+\mathrm{H}_{2} \mathrm{O}_{2} \rightarrow \mathrm{SO}_{4}^{2-}+\mathrm{H}^{+}+\mathrm{H}_{2} \mathrm{O}
$$

Sulfites may also inhibit radical formation by reducing lipid and protein hydroperoxides to the corresponding alcohol without formation of radicals (eq. 2) (Serrano \& Bañón, 2012).

$$
\mathrm{HSO}_{3}{ }^{-}+\mathrm{ROOH} \rightarrow \mathrm{SO}_{4}{ }^{2-}+\mathrm{H}^{+}+\mathrm{ROH}
$$

In addition, sulfites may protect against protein radical formation by acting as a radical scavenger (Andersen et al., 2000). Protein radicals may also be scavenged by sulfites (eq. 3) (Neta \& Huie, 1985), forming sulfite radicals that may undergo radical termination process (eq. 4) (Hayon et al., 1972).

$$
\begin{gathered}
\text { Protein }+\mathrm{HSO}_{3}{ }^{-} \rightarrow \text { Protein }+\mathrm{SO}_{3}^{-} \\
2 \mathrm{~S} \mathrm{O}_{3}^{-} \rightarrow \mathrm{S}_{2} \mathrm{O}_{6}{ }^{-{ }^{-}}
\end{gathered}
$$

\subsection{Protein thiol loss}

Protein thiols are highly susceptible to oxidation by radicals and transition metal ions leading to loss of thiol groups. Thiol oxidation may serve as an antioxidant mechanism to prevent other substrates from oxidation, and is in general considered a marker of protein oxidation in meat (Lund et al., 2011). Protein thiol loss was evaluated in the MPI obtained from the samples stored for 15 days (Figure 6.3.). At day 0, samples added red and white SkWPP contained approximately $40 \%$ less protein thiols than the control samples and samples added sulfite. As there may be some SkWPP remaining in the MPI that could interfere in the result of the DTNB assay, a set of 
control experiments were conducted for the reaction mixture of DTNB and the thiol group of cysteine (Cys-SH). The thiol-exchange reaction to form the yellow thiolate anion (NB-S ${ }^{-}$) from the weakly colored disulfide reagent (NB-SS-BN) is:

$$
\text { Cys-SH }+ \text { NB-SS-BN } \rightarrow \text { Cys-SS-BN + NB-S- }
$$

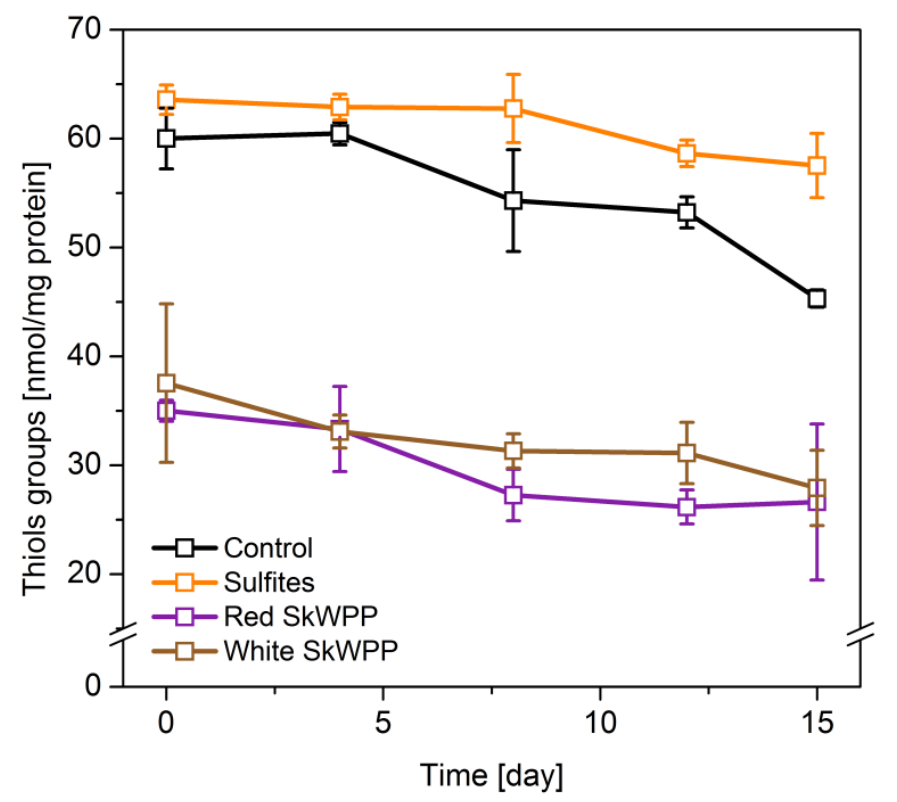

Figure 6.3. Protein thiol concentration (mean $\pm \mathrm{SD}, \mathrm{n}=3$ ) in myofibrillar protein isolates (MPI) extracted from beef patties without addition of any antioxidant (Control) or with addition of sulfites $\left(300 \mathrm{ppm} \mathrm{SO}_{2}\right.$ ), red or white skin wine pomace product (SkWPP, $2 \% \mathrm{w} / \mathrm{w}$ ) stored in high-oxygen atmosphere for 15 days at $4{ }^{\circ} \mathrm{C}$.

When pure SkWPP was added to the reaction mixture containing cysteine and DTNB before the 30 minutes incubation time, the formation of the thiolate anion (NB$\mathrm{S}^{-}$) decreased significantly. However, adding pure SkWPP to the reaction mixture of DTNB and cysteine after 30 minutes reaction, no loss in the level of the yellow thiolate anion was observed. This suggested that the interference from components in SkWPP was a result of a reaction between the thiol group of the cysteine to form an addition products "Cys-SkWPP" rather than with the yellow thiolate anion for the quantification (eq. 6).

$$
\text { Cys-SH + NB-SS-BN + SkWPP } \rightarrow \text { “Cys-S-SkWPP” + NB-SS-BN }
$$


As a further control, instead of pure SkWPP, MPI obtained from meat samples

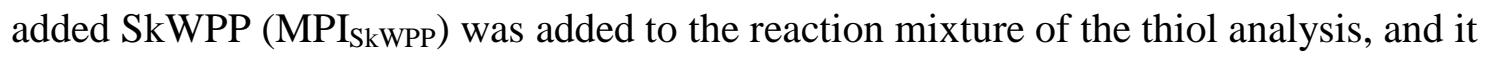
was found, that MPI $\mathrm{SkWPP}_{\mathrm{S}}$ did not affect the reaction between cysteine and DNTB:

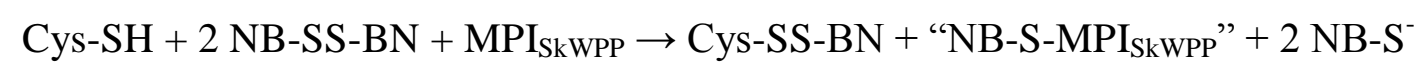

The fact that pure SkWPP, in contrast to the SkWPP residues in the MPI, was reactive towards cysteine demonstrated the presence of thiol-reactive components in the SkWPP. This indicates that the lower protein thiol concentrations found in beef patties added SkWPP were the actual level of protein thiols and the lowering in protein thiol concentration was most likely caused by reaction between thiol-reactive compounds in SkWPP and the protein thiol groups in the beef patties, as also previously described (Jongberg et al., 2011a).

Sulfites added to patties could be another source of interference with the DNTB resulting in an overestimation of the thiol content due to sulfitolysis of the DNTB (Morel et al., 2000). However, no residual sulfite remaining was detected in the MPI obtained from patties added sulfites and there was no significant difference between control samples and samples added sulfite at day 0 , indicating that sulfite residues were completely removed by the extensive washing procedure during the MPI preparation.

During storage, the protein thiol content decreased significantly in all samples (Figure 6.3.). After 15 days of storage, the largest protein thiol loss was observed in the control samples ( $15 \mathrm{nmol}$ thiol/mg protein), while the decrease in samples containing sulfites was only $8 \mathrm{nmol}$ thiol/mg protein. Significant differences between samples added sulfites and control were observed at day 8, 12 and 15, indicating a protective effect of sulfite against protein thiol loss in the beef patties added sulfite. As mentioned earlier, sulfites are able to remove several oxidizing agents such as $\mathrm{H}_{2} \mathrm{O}_{2}$, peroxides and 
radicals, and hence, will protect proteins against thiol loss. The protein thiol loss in beef patties added red or white SkWPP during the 15 days storage was comparable to the loss observed in the beef added sulfite, although the concentration at day 0 was considerable lower. The reduced thiol loss in beef added SkWPP as compared to the control sample is concluded to result from the antioxidant capacity of SkWPP against thiol oxidation. However, taking the low starting level into consideration, conclusions should be drawn very carefully. Sun et al. (2011) showed that thiols were only lost to a certain level during long-term drying of Cantonese sausages indicating that some thiols in MPI are not available for oxidation. Thus, the low thiol loss in the beef patties added SkWPP may be due to inaccessible thiols rather than to a true antioxidant activity. Addition of either red or white SkWPP resulted in similar low starting level and low thiol loss during storage, despite the difference between the two products observed in the formation of protein radicals. This stresses that the radical scavenging activity of the components in the individual SkWPP was negligible with regards to protection against thiol loss.

\subsection{Characterization of protein cross-linking}

Thiol groups are highly susceptible to oxidation, which among other reactions leads to formation of disulfides. As a result, protein thiol oxidation changes the structural properties of myosin heavy chain (MHC) due to disulfide cross-linking (Lund et al., 2011). This reaction can be assayed by gel electrophoresis, which allows separation of cross-linked MHC (CL-MHC) as a dimer from MHC. In the present study, both loss of myosin heavy chain (MHC) as well as formation of cross-linked MHC (CL-MHC) were investigated by gel electrophoresis (Figure 6.4.), and the intensities of protein bands were analyzed by a semi-quantitative approach in order to compare the levels of MHC and CL-MHC in the meat samples (Figures 6.5. and 6.6.). 


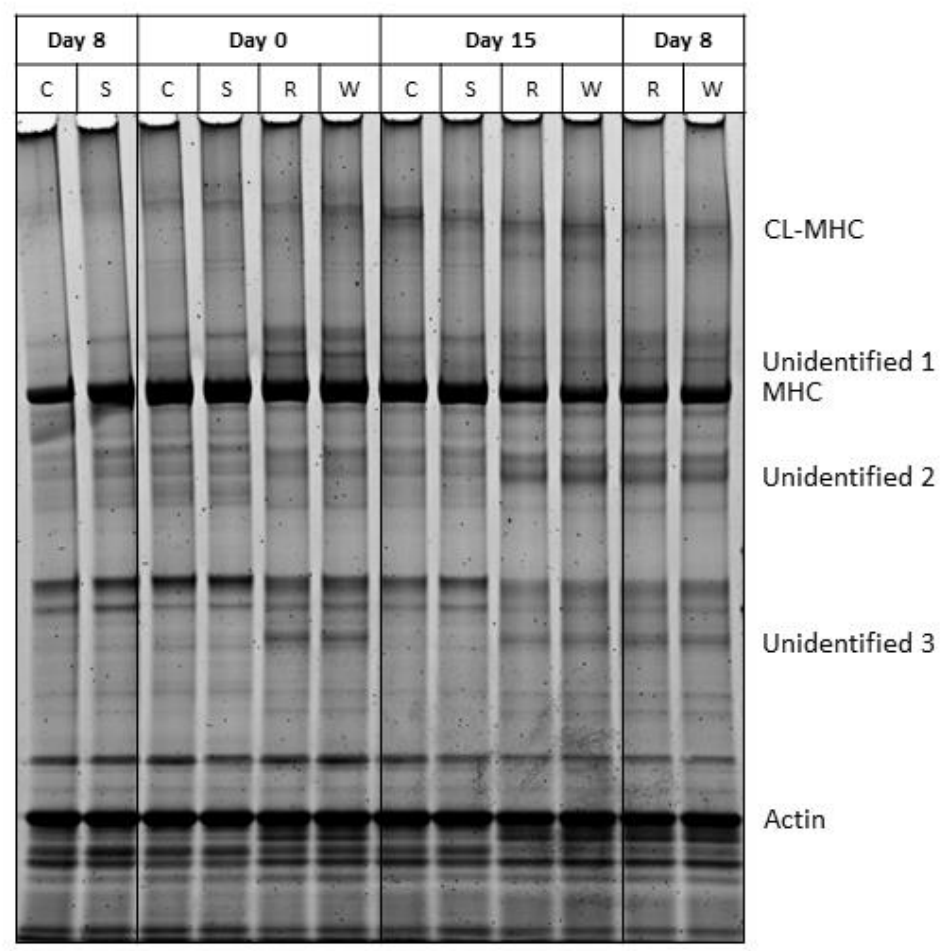

Figure 6.4. Representative SDS-Gel of MPI from beef patties (C), added sulfites (S), red $(\mathrm{R})$ and white $(\mathrm{W})$ skin wine pomace product packaged in high-oxygen atmosphere $\left(70 \% \mathrm{O}_{2} / 30 \% \mathrm{CO}_{2}\right)$ and stored for 0,8 and 15 days at $4{ }^{\circ} \mathrm{C}$. Myosin heavy chain (MHC), cross-linked MHC (CL-MHC), and actin are indicated on the gel, as well as unidentified proteins 1, 2, and 3. Samples from day 0 and 15 were run in the central lanes of the gel to ensure the highest quality in protein separation of these samples.

Gel electrophoresis revealed that at the end of storage, the dimer (CL-MHC) was formed, and was especially visual for the control sample (Figure 6.4.). The CLMHC was not found in the samples run after reduction by dithiothreitol (DTT), indicating that the dimer CL-MHC is formed through reducible disulfide bonds, as also reported elsewhere for meat stored in HiOx MAP (Kim et al., 2010). The formation of CL-MHC is linked to a serious loss in sensory properties, especially tenderness and juiciness (Kim et al., 2010; Lund et al., 2011). In contrast, the presence of sulfite, or red or white SkWPP in beef patties partly prevented the formation of CL-MHC during storage, indicating that these additives all protected against protein cross-linking induced by oxidation. 

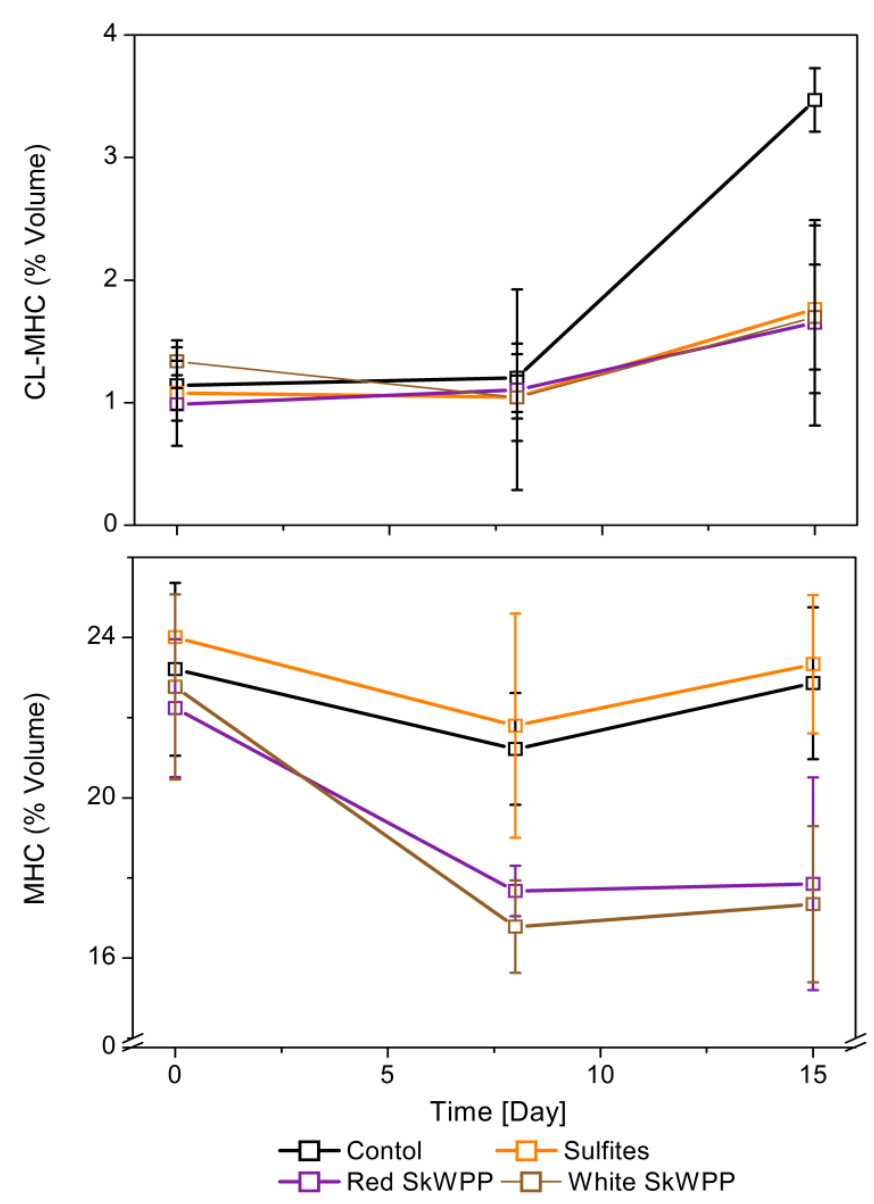

Figure 6.5. Percentage volume (mean $\pm \mathrm{SD}, \mathrm{n}=3$ ) of cross-linked myosin heavy chain (CL-MHC) (upper panel) and myosin heavy chain (MHC) (lower panel) separated by SDS-PAGE in control beef patties (C), and beef patties added sulfite (300 $\mathrm{ppm} \mathrm{SO}_{2}$ ), red or white skin wine pomace product (SkWPP, 2\% w/w) stored for 0, 8 and 15 days in high-oxygen atmosphere packaging $\left(70 \% \mathrm{O}_{2} / 30 \% \mathrm{CO}_{2}\right)$ at $4{ }^{\circ} \mathrm{C}$. Values are means of three independent replicates.

Sulfite is able to reduce disulfides leading to the formation of S-sulfonates (eq. 8) (Cecil \& McPhee, 1955).

$$
\mathrm{P}-\mathrm{S}-\mathrm{S}-\mathrm{P}+\mathrm{HSO}_{3}{ }^{-} \rightarrow \mathrm{PS}_{-} \mathrm{SO}_{3}{ }^{-}+\mathrm{PSH} \text { (eq. 8) }
$$

In the present study, sulfite was found to reduce the level of protein radicals and to partly prevent thiol loss, which complies with the low level of protein cross-linking as observed by the gel electrophoresis. 

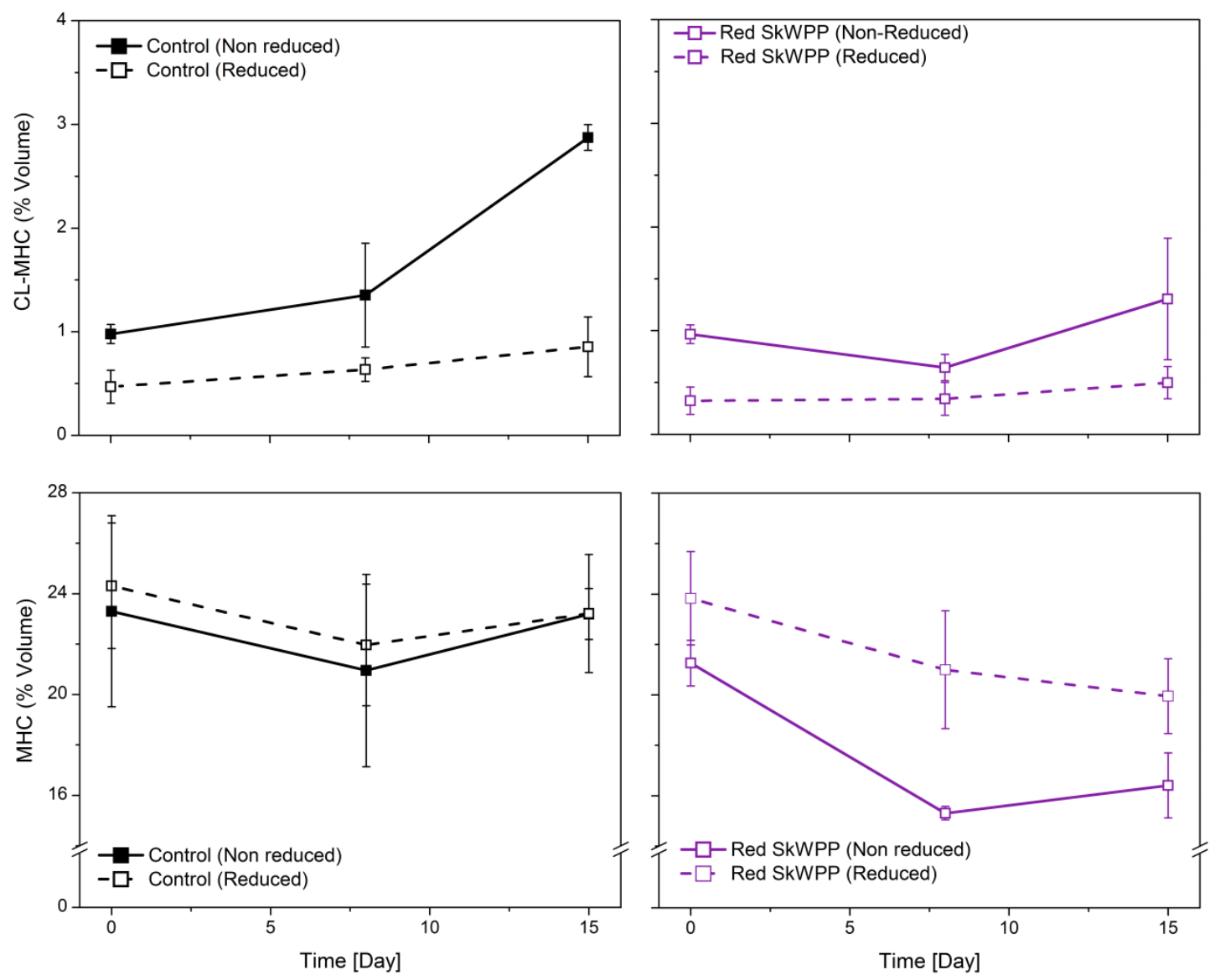

Figure 6.6. Percentage volume (mean $\pm \mathrm{SD}, \mathrm{n}=3$ ) of cross-linked myosin heavy chain (CL-MHC) (upper panels) and myosin heavy chain (MHC) (lower panels) separated by SDS-PAGE in control beef patties (left panels), and beef patties added red skin wine pomace product (SkWPP, 2\% w/w) (right panels) stored for 0, 8 and 15 days in highoxygen atmosphere packaging $\left(70 \% \mathrm{O}_{2} / 30 \% \mathrm{CO}_{2}\right)$ at $4{ }^{\circ} \mathrm{C}$. Solid lines correspond to non-reduced samples and dotted lines correspond to samples previously reduced by DTT. Values are means of three independent replicates.

Even though SkWPP partly prevented CL-MHC formation (Figure 6.4.), samples added SkWPP was found to generate new protein bands which were not seen in control samples or in samples added sulfite. The three unidentified protein bands (Unidentified 1, 2, and 3) are indicated in Figure 6.4. The unidentified bands 1 and 3 were most prominent at day 0 and seem to disappear during storage, whereas the unidentified band 2 was most prominent at day 15 and seem to be formed during storage. The molecular weights were estimated to be $220 \mathrm{KDa}, 155 \mathrm{KDa}$ and $90 \mathrm{KDa}$, respectively. When the samples were run in their reduced state, the unidentified bands 
disappeared, suggesting that these bands were formed through reducible protein crosslinking. An increase in protease activity may also explain the unidentified bands, as increased proteolysis could lead to the formation of new peptides that could become subsequently cross-linked and form new protein bands. However, this seems unlike since polyphenols have been traditionally considered enzyme inhibitors due to the conformational changes produced in the enzyme structures as well as the modification produced in their substrate (Sartor et al., 2002).

\subsection{Quantification of protein-cross-linking}

The band intensities were determined and used as a semi-quantitative measure of the degree of protein cross-link formation. Control beef patties had significant higher CL-MHC levels as compared to the other samples (Figure 6.5., upper panel). As already seen from the gel, red and white SkWPP was able to prevent formation of CLMHC to a similar level as by addition of sulfite. However, in contrast to both the control beef patties and beef patties added sulfite, addition of SkWPP resulted in a significant decrease in the MHC band intensity at day 8 and 15 as compared to day 0 (Figure 6.5., lower panel). This indicates that the MHC in the beef patties added SkWPP was modified during storage.

As mentioned, treatment by DTT significantly reduced the band intensity of the dimer CL-MHC formed in the control beef patties (Figure 6.6., upper left panel) indicating that the CL-MHC were formed through reducible disulfide protein crosslinks. The MHC band intensity increased significantly in beef patties added SkWPP stored for 8 or 15 days after treatment by DTT, indicating that the low MHC level observed in these samples were partially due to reducible modifications or polymerization reactions generated during storage (Figure 6.6., lower right panel). Meanwhile, the MHC level in the control beef patties did not change significantly after 
treatment by DTT (Figure 6.6., lower left panel) indicating that no reducible modifications were generated. By comparing the levels of MHC in the control beef patties and beef patties added red SkWPP after treatment by DTT it becomes clear that MHC in the beef patties added red SkWPP was only partially recovered by treatment with DTT, suggesting that some protein polymers in the beef patties added SkWPP were generated through non-reducible cross-links. Jongberg et al. (2013) found that addition of green tea extract to Bologna type sausages modified the myofibrillar proteins through covalent thiol-quinone adduct formation causing phenol-mediated protein cross-linking. Both reducible and non-reducible protein cross-links were reported in pork patties added essential oil of rosemary or oregano (Nieto et al., 2013), and Hagerman et al. (1998) observed that the addition of DTT did not increase the solubility of the precipitate formed by reaction between two different tannins and bovine serum albumin, indicating that a considerable proportion of protein-phenol interactions may be resistant to strong reducing agents such as DTT.

\subsection{Protein-phenol interactions}

The results of the present study suggests that protein cross-links generated through reaction with quinones from the SkWPP may be responsible for the unidentified protein bands observed on the gel (Figure 6.4.). Quinones are extensively formed during the vinification process and the subsequent processing. Since the SkWPP are obtained from the by-product of vinification, the phenolics may already have been subjected to oxidation leading to the formation of quinones. As mentioned, quinones reacts rapidly with nucleophiles in meat to generate thiol-quinone adducts (Jongberg et al., 2011a).

Protein-phenol interactions have been suggested not only to change the protein structure but also to play a key role in the protection against deteriorative reactions of 
proteins (Viljanen et al., 2005). Phenols incorporated into the protein structure may exert their antioxidant protection locally on the protein structure (Satué-Gracia et al., 1997). In the present study, proanthocyanidins were found in both products in relatively high concentrations, and may be responsible for the reduced protein thiol concentration due to thiol-quinone interactions, and subsequently reduced CL-MHC levels. The difference between the molecular weight of MHC and the unidentified band 1 was $~ 20$ $\mathrm{KDa}$. Seventy units of catechin could produce the observed increase in the molecular weight of MHC. Similar polymerization degrees have previously been detected in grape skin (Pinelo et al., 2006), and the reaction between such structures and the myofibrillar proteins may have caused the formation of the unidentified protein bands. Moreover, polyphenols in wine pomace are usually associated with an elevated content of fiber (García-Lomillo et al., 2014). The incorporation of large polymers of fiber into the protein structure could also contribute to the increase in the molecular weight of MHC due to addition reactions.

\section{CONCLUSIONS}

Red SkWPP protected against protein radical formation, unlike white SkWPP, and may be an interesting antioxidant in meat products. During storage, red and white SkWPP protected against the formation of the dimer CL-MHC, but resulted in loss of native $\mathrm{MHC}$ and in formation of unidentified protein structures, presumably MHC modified through protein-phenol interactions. However, both red and white SkWPP were found to result in an instant drop in protein thiol concentration at day 0 . Sulfite added to beef patties was found to be an effective antioxidant towards protein oxidation in beef patties stored in high-oxygen atmosphere, since not only thiol loss was reduced, but also the formation of protein radical and cross link were inhibited. 


\section{REFERENCES}

Abrahamsson, V., Hoff, S., Nielsen, N. J., Lund, M. N., \& Andersen, M. L. (2012). Determination of sulfite in beer based on fluorescent derivatives and liquid chromatographic separation. Journal of the American Society of Brewing Chemists, 70(4), 296-302.

Andersen, M. L., Outtrup, H., \& Skibsted, L. H. (2000). Potential antioxidants in beer assessed by ESR spin trapping. Journal of Agricultural and Food Chemistry, 48(8), 3106-3111.

Barceló, J. G. (1990). 8. Compuestos fenólicos. Técnicas analíticas para vinos 1st ed., (pp. 8.3 - 8.33). Barcelona: GAB.

Benjakul, S., Sungsri-in, R., \& Kijroongrojana, K. (2012). Effect of Treating of Squid with Sodium Chloride in Combination with Oxidising Agent on Bleaching, Physical and Chemical Changes During Frozen Storage. Food and Bioprocess Technology, 5(6), 2077-2084.

Brewer, M. S. (2011). Natural Antioxidants: Sources, Compounds, Mechanisms of Action, and Potential Applications. Comprehensive Reviews in Food Science and Food Safety, 10(4), 221-247.

Cecil, R., \& McPhee, J. R. (1955). A kinetic study of the reactions on some disulphides with sodium sulphite. The Biochemical journal, 60(3), 496-506.

Council Directive $N^{\circ}$ 95/2/EC of 20 February 1995 on food additives other than colours and sweeteners. (1995).

Davies, M. J. (1990). Detection of myoglobin-derived radicals on reaction of metmyoglobin with hydrogen peroxide and other peroxidic compounds. Free Radical Research Communications, 10(6), 361-370.

Fu, Q.-q., Liu, R., Zhang, W.-g., Li, Y.-p., Wang, J., \& Zhou, G.-h. (2015). Effects of Different Packaging Systems on Beef Tenderness Through Protein Modifications. Food and Bioprocess Technology, 8(3), 580-588.

Ganhão, R., Morcuende, D., \& Estévez, M. (2010). Protein oxidation in emulsified cooked burger patties with added fruit extracts: Influence on colour and texture deterioration during chill storage. Meat Science, 85(3), 402-409.

García-Lomillo, J., González-SanJosé, M. L., Del Pino-García, R., Rivero-Pérez, M. D., \& Muñiz-Rodríguez, P. (2014). Antioxidant and antimicrobial properties of wine byproducts and their potential uses in the food industry. Journal of Agricultural and Food Chemistry, 62(52), 12595-12602.

Hagerman, A. E., Rice, M. E., \& Ritchard, N. T. (1998). Mechanisms of Protein Precipitation for Two Tannins, Pentagalloyl Glucose and Epicatechin16 $(4 \rightarrow 8)$ Catechin (Procyanidin). Journal of Agricultural and Food Chemistry, 46(7), 2590-2595.

Hayon, E., Treinin, A., \& Wilf, J. (1972). Electronic spectra, photochemistry, and autoxidation mechanism of the sulfite-bisulfite-pyrosulfite systems. The $\mathrm{SO} 2$-, SO3 -, SO4 -, and SO5 - radicals. Journal of the American Chemical Society, 94(1), 47-57. 
Jiménez-Colmenero, F., Carballo, J., \& Cofrades, S. (2001). Healthier meat and meat products: their role as functional foods. Meat Science, 59(1), 5-13.

Jongberg, S., Gislason, N. E., Lund, M. N., Skibsted, L. H., \& Waterhouse, A. L. (2011a). Thiol-Quinone Adduct Formation in Myofibrillar Proteins Detected by LC-MS. Journal of Agricultural and Food Chemistry, 59(13), 6900-6905.

Jongberg, S., Skov, S. H., Tørngren, M. A., Skibsted, L. H., \& Lund, M. N. (2011b). Effect of white grape extract and modified atmosphere packaging on lipid and protein oxidation in chill stored beef patties. Food Chemistry, 128(2), 276-283.

Jongberg, S., Tørngren, M. A., Gunvig, A., Skibsted, L. H., \& Lund, M. N. (2013). Effect of green tea or rosemary extract on protein oxidation in Bologna type sausages prepared from oxidatively stressed pork. Meat Science, 93(3), 538546.

Jongberg, S., Wen, J., Tørngren, M. A., \& Lund, M. N. (2014). Effect of high-oxygen atmosphere packaging on oxidative stability and sensory quality of two chicken muscles during chill storage. Food Packaging and Shelf Life, 1(1), 38-48.

Kim, Y. H., Huff-Lonergan, E., Sebranek, J. G., \& Lonergan, S. M. (2010). Highoxygen modified atmosphere packaging system induces lipid and myoglobin oxidation and protein polymerization. Meat Science, 85(4), 759-767.

Lund, M. N., Heinonen, M., Baron, C. P., \& Estévez, M. (2011). Protein oxidation in muscle foods: A review. Molecular Nutrition and Food Research, 55(1), 83-95.

Martínez, B., Miranda, J., Vázquez, B., Fente, C., Franco, C., Rodríguez, J., \& Cepeda, A. (2012). Development of a Hamburger Patty with Healthier Lipid Formulation and Study of its Nutritional, Sensory, and Stability Properties. Food and Bioprocess Technology, 5(1), 200-208.

Martínez, B., Miranda, J. M., Franco, C. M., Cepeda, A., \& Vázquez, M. (2011). Evaluation of transglutaminase and caseinate for a novel formulation of beef patties enriched in healthier lipid and dietary fiber. LWT - Food Science and Technology, 44(4), 949-956.

McFeeters, R. F. (1998). Use and removal of sulfite by conversion to sulfate in the preservation of salt-free cucumbers. Journal of Food Protection, 61(7), 885890.

McManus, J. P., Davis, K. G., Beart, J. E., Gaffney, S. H., Lilley, T. H., \& Haslam, E. (1985). Polyphenol interactions. Part 1. Introduction; some observations on the reversible complexation of polyphenols with proteins and polysaccharides. Journal of the Chemical Society, Perkin Transactions 2(9), 1429-1438.

Mildner-Szkudlarz, S., Zawirska-Wojtasiak, R., Szwengiel, A., \& Pacyński, M. (2011). Use of grape by-product as a source of dietary fibre and phenolic compounds in sourdough mixed rye bread. International Journal of Food Science and Technology, 46(7), 1485-1493.

Morel, M. H., Bonicel, J., Micard, V., \& Guilbert, S. (2000). Protein Insolubilization and Thiol Oxidation in Sulfite-Treated Wheat Gluten Films during Aging at Various Temperatures and Relative Humidities. Journal of Agricultural and Food Chemistry, 48(2), 186-192. 
Neta, P., \& Huie, R. E. (1985). Free-radical chemistry of sulfite. Environmental Health Perspectives, VOL. 64, 209-217.

Nieto, G., Jongberg, S., Andersen, M. L., \& Skibsted, L. H. (2013). Thiol oxidation and protein cross-link formation during chill storage of pork patties added essential oil of oregano, rosemary, or garlic. Meat Science, 95(2), 177-184.

Nissen, L. R., Månsson, L., Bertelsen, G., Huynh-Ba, T., \& Skibsted, L. H. (2000). Protection of Dehydrated Chicken Meat by Natural Antioxidants as Evaluated by Electron Spin Resonance Spectrometry. Journal of Agricultural and Food Chemistry, 48(11), 5548-5556.

Pérez-Magariño, S., \& González-San José, M. L. (2001). Influence of commercial pectolytic preparations on the composition and storage evolution of Albillo white wines. International Journal of Food Science and Technology, 36(7), 789-796.

Pinelo, M., Arnous, A., \& Meyer, A. S. (2006). Upgrading of grape skins: Significance of plant cell-wall structural components and extraction techniques for phenol release. Trends in Food Science \& Technology, 17(11), 579-590.

Rivero-Pérez, M. D., Muñiz, P., \& González-Sanjosé, M. L. (2008). Contribution of anthocyanin fraction to the antioxidant properties of wine. Food and Chemical Toxicology, 46(8), 2815-2822.

Sabeena Farvin, K. H., Grejsen, H. D., \& Jacobsen, C. (2012). Potato peel extract as a natural antioxidant in chilled storage of minced horse mackerel (Trachurus trachurus): Effect on lipid and protein oxidation. Food Chemistry, 131(3), 843851.

Sartor, L., Pezzato, E., Dell'Aica, I., Caniato, R., Biggin, S., \& Garbisa, S. (2002). Inhibition of matrix-proteases by polyphenols: chemical insights for antiinflammatory and anti-invasion drug design. Biochemical Pharmacology, 64(2), 229-237.

Satué-Gracia, M. T., Heinonen, M., \& Frankel, E. N. (1997). Anthocyanins as Antioxidants on Human Low-Density Lipoprotein and Lecithin-Liposome Systems. Journal of Agricultural and Food Chemistry, 45(9), 3362-3367.

Serrano, R., \& Bañón, S. (2012). Reducing SO2 in fresh pork burgers by adding chitosan. Meat Science, 92(4), 651-658.

Stadtman, E. R. (1990). Metal ion-catalyzed oxidation of proteins: Biochemical mechanism and biological consequences. Free Radical Biology and Medicine, 9(4), 315-325.

Sun, W., Cui, C., Zhao, M., Zhao, Q., \& Yang, B. (2011). Effects of composition and oxidation of proteins on their solubility, aggregation and proteolytic susceptibility during processing of Cantonese sausage. Food Chemistry, 124(1), 336-341.

Tseng, A., \& Zhao, Y. (2013). Wine grape pomace as antioxidant dietary fibre for enhancing nutritional value and improving storability of yogurt and salad dressing. Food Chemistry, 138(1), 356-365. 
Vally, H., \& Misso, N. L. A. (2012). Adverse reactions to the sulphite additives. Gastroenterology and Hepatology from Bed to Bench, 5(1), 16-23.

Viljanen, K., Halmos, A. L., Sinclair, A., \& Heinonen, M. (2005). Effect of blackberry and raspberry juice on whey protein emulsion stability. European Food Research and Technology, 221(5), 602-609.

Vuorela, S., Salminen, H., Mäkelä, M., Kivikari, R., Karonen, M., \& Heinonen, M. (2005). Effect of plant phenolics on protein and lipid oxidation in cooked pork meat patties. Journal of Agricultural and Food Chemistry, 53(22), 8492-8497.

Xiong, Y. L. (2000). Antioxidants in muscle foods. E. A. Decker, C. Faustman \& C. J. Lopez-Bote (Eds.), Protein oxidation and implications for muscle food quality., (pp. 85-112). New York: John Wiley \& Sons, Inc. 


\section{Chapter 7:}

EfFect of Red Wine Pomace Seasoning on THE FORMATION OF MEAT COOKING Carcinogens in Beef Patties Before and 



\section{Presentación}

En Octubre del 2015, la organización mundial de la salud incluyó a la carne procesada dentro del grupo de agentes cancerígenos. Entre las razones citadas para ello, se encontraron la formación de hidrocarburos aromáticos policíclicos (HAPs) y aminas heterocíclicas (AHs) formados en los tratamientos a altas temperaturas de la carne. Algunos trabajos han descrito la capacidad de los productos derivados de la uva para mitigar la formación de dichos compuestos (ver capítulo 1). Por todo ello, se consideró conveniente evaluar la capacidad del sazonador procedente de la piel de orujo tinto para limitar la formación de HAPs y AHs en hamburguesas cocinadas en barbacoa, siendo este estudio el que se muestra en este capítulo. Dado que algunos estudios indican que un factor que favorece la formación de HAPs y AHs es el tiempo de conservación el estudio se llevó a cabo con hamburguesas recién preparadas y almacenadas.

\section{Resultados más relevantes}

El uso del sazonador produjo efectos similares en ambos grupos de compuestos HAPs y AHs estudiados. Se observó un ligero aumento de sus niveles en las muestras elaboradas con el sazonador y cocinadas recién hechas. Mientras que en las muestras conservadas durante 9 días la formación de HAPs y AHs fue menor en aquellas elaboradas con el sazonador. Los resultados fueron correlacionados positivamente con la capacidad antioxidante (valor ABTS) de las muestras, lo cual podría sugerir una relación entre la captación de radicales y la formación de estos compuestos. 



\title{
Chapter 7: Effect of Red Wine Pomace Seasoning on the Formation of
}

\section{Meat Cooking Carcinogens in Beef Patties Before and After Storage}

\begin{abstract}
The formation of polycyclic aromatic hydrocarbons (PAHs), and heterocyclic amines (HAs) during heat treatment of meat has received considerable attention due to the carcinogenic activity of these compounds. This study aims to evaluate the effect of a seasoning derived from red wine pomace (RWPS) on the formation of PAHs and HAs, in beef patties. Alternatively, the effect of storage in high-oxygen atmosphere packaging with and without RWPS was evaluated. Generally, the quantified levels of PAHs and HAs were relatively low. Patties with RWPS cooked the same day of preparation, presented higher levels of PAHs and HAs when compared with control patties. 9-day storage promoted higher formation of PAHs, but not HAs, in the barbecued control samples, whereas RWPS samples presented the opposite effect. Patties cooked after 9day storage with RWPS, presented lower levels of PAHs and HAs than control samples at 9 day and RWPS patties at day 0 . The same trend was observed in the results of ABTS assay, which may suggest a correlation between PAHs and HAs formation and the radical scavenging activity of the samples. In conclusion, RWPS could be an interesting ingredient to inhibit the formation of carcinogenic compounds in stored meat.
\end{abstract}

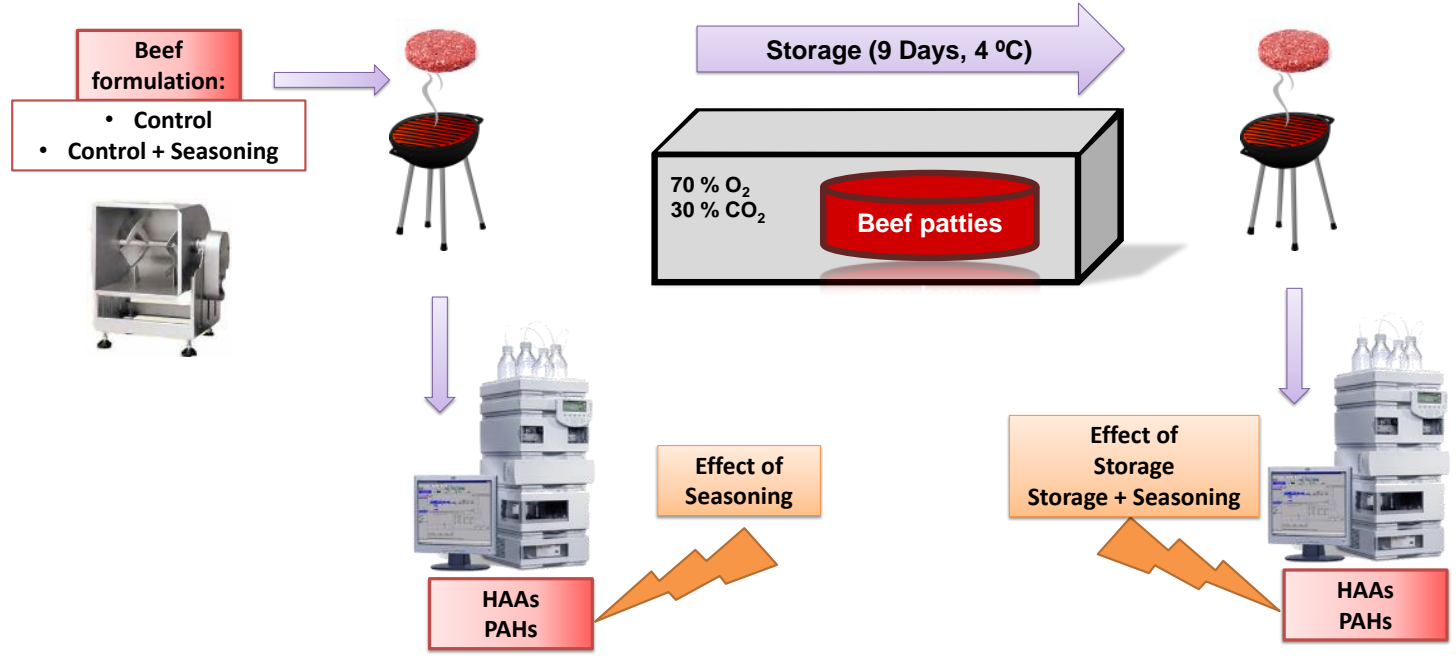




\section{INTRODUCTION}

Meat and meat products contain high biological-valuable components including protein, vitamins, iron and zinc. Meat cooking improves the digestibility and prevents microbiological hazards, but also produces carcinogenic chemicals that have drawn the attention of scientific community. In October, 2015, the International Agency for Research on Cancer (IARC) classified "processed meat" and "red meat" as "carcinogenic" and "probably carcinogenic" to humans (groups 1 and 2A), respectively (Bouvard et al., 2015), based on more than 800 epidemiological studies that reported the link between meat consumption and 16 types of cancer, especially colorectal, pancreas and stomach cancers. Polycyclic aromatic hydrocarbons (PAHs), and heterocyclic amines (HAs) were pointed out as the components of cooked meat with the highest carcinogenic potential (Bouvard et al., 2015).

PAHs are mainly formed when meat is cooked over an open flame. Although the mechanisms are not completely understood, several theories have been proposed to explain the formation of PAHs. Organic matter seems to be fragmented at high temperatures through pyrolysis producing free radicals that can recombine producing new stable polynuclear aromatic compounds by pyrosynthesis. High temperatures (at least $200^{\circ} \mathrm{C}$ ) are required to form relevant amounts of PAHs (Chen \& Chen, 2001; Sharma et al., 2006). In samples cooked over an open flame, the incomplete combustion of the heat source may generate low molecular weight PAHs, or "light PAHs" (with 2-3 aromatic aromatic rings). In barbecued food, melted fat drips onto the heat source generating PAHs with more than 3 aromatic rings ("heavy PAHs") that are brought again on the surface of the food due to their volatile nature. This mechanism

seems to be the most important mechanism of formation due to the large amount of PAHs generated and the higher toxicity of heavy PAHs (Viegas et al., 2012c). 
The assessment of health risk associated to PAHs exposure has been addressed in different ways (Yebra-Pimentel et al., 2015). The surrogate approach evaluates the potential risk by using a unique compound as indicator; typically benzo(a)pyrene (BaP). In a second approach (relative potency factor) the toxic potential of each compound is related to a toxicity factor, typically assigning $\mathrm{BaP}$ a value of 1 . However, EFSA discouraged the use of the relative potency approach, due to the lack of data concerning, oral carcinogenicity, mechanisms of action and synergistic effects between PAHs. According to the EU Scientific Committee on Food, the most suitable indicator for the occurrence and carcinogenic potency of PAHs in food is the sum of the following PAHs (PAH8): benzo(a)anthracene (BaA), chrysene (CHR), benzo(b)fluoranthene $\quad(\mathrm{BbFA}), \quad$ benzo(k)fluoranthene $\quad(\mathrm{BkFA}), \quad \mathrm{BaP}$, dibenzo(a,h)anthracene (DBahA), benzo(g,h,i)perylene (BghiP), and indeno(1,2,3c,d)pyrene (IP) (EFSA, 2008).

HAs is another category of carcinogenic compounds formed in treatments at high temperature of meat products. They contain 3 fused aromatic rings, one or more nitrogen atoms in the ring and one exocyclic amino group. HAs are usually classified as thermic (formed at temperatures between 150 and $250^{\circ} \mathrm{C}$ ) and pyrolytic (formed at temperatures above $250^{\circ} \mathrm{C}$ ). The formation of thermic HAs is linked to the reaction between creatinine (derived from the cyclization and water elimination of creatine) and Strecker degradation products derived from Maillard reaction (Skog et al., 1998).

Packaged raw meat is usually stored under refrigerated conditions in highoxygen atmosphere in order to keep the bright red color, which is highly appreciated by consumers. However, those conditions induce oxidative processes, namely depletion of endogenous antioxidants, lipid and protein oxidation and radical accumulation. 
Recently, it has been observed that cooked meat after storage presented higher formation of HAs, which was ascribed to the formation of precursors during storage specially free amino acids (Polak et al., 2009; Szterk et al., 2012; Szterk \& Waszkiewicz-Robak, 2014) . Since PAHs formation is also mediated by radical chain reactions, the oxidative status of meat may also affect the formation of PAHs but the effect of storage on PAHs formations has not been described.

Different strategies to mitigate the formation of PAHs and HAs in barbecued meat have been proposed, including lower cooking temperatures, reduction of smoke release, avoid fat dripping and keep meat away from heat source (Lee et al., 2016; Skog et al., 1998). Moreover, natural products such as spices and plant extracts have been proposed to limit the formation of PAHs and HAs due to the ability of phenolic compounds to act as radical scavenger, breaking radical chain reactions. Recent studies demonstrated that marinating with beer (Viegas et al., 2014) or cooking with onion and garlic (Janoszka, 2011) reduced the formation of PAHs, whereas grape seed extract, and wine marinades inhibited HAs formation (Ahn \& Grün, 2005; Busquets et al., 2006; Melo et al., 2008; Viegas et al., 2012a; Viegas et al., 2015).

Recently, a new seasoning derived from red wine pomace was developed with preservative activity inhibiting microbial growth, lipid and protein oxidation (GarciaLomillo et al., 2016; García-Lomillo et al., 2014). RWPS is known to be rich in phenolic compounds (Del Pino-García et al., 2016), predominating flavonoid compounds, mainly anthocyanins with the usal predominance of malvidin derivates, followed by flavan-3-ols (mainly oligomers) and some flavonols (especially myricetin derivates), although phenolic acids are also present. The aim of the present work was to 
evaluate the effect of the red wine pomace seasoning (RWPS) on the formation of PAHs and HAs in barbecued beef patties before and after 9 days of storage.

\section{MATERIALS AND METHODS}

\subsection{Chemicals}

For ABTS assay, 2,2'-Azinobis 3-ethylbenzothiazoline-6-sulfonic acid (ABTS reagent), 6-hydroxy-2,5,7,8-tetramethyl-2-carboxylic acid (Trolox) were obtained from Sigma and potassium persulfate $\left(\mathrm{K}_{2} \mathrm{O}_{8} \mathrm{~S}_{2}\right)$ from Panreac (Barcelona, Spain).

For PAHs analysis, the standard PAH mixture of naphthalene, acenaphthene, acenaphthylene, fluorene, phenanthrene, anthracene (A), fluoranthene (FA), pyrene (PYR), BaA, CHR, BbFA, BkFA, BaP, DBahA, BghiP, and IP was provided by Supelco, (Bellefonte, PA, USA) The glassware used was ambar and previously washed and rinsed with diacetone and hexane before being used. Acetonitrile, ethyl acetate, $n$ hexane were of HPLC grade and were obtained from Merck (Darmstadt, Germany). Water was purified using a Milli-Q System (Millipore, Bedford, MA, USA). Dichloromethane and methanol obtained for Sigma (St Louis, MO, USA) were passed through membrane nylon $0.22 \mu \mathrm{m}$ from Magna before injection into the HPLC system.

For HAs analysis, standards, 2-amino-3-methylimidazo[4,5-f]quinoline (IQ), 2amino-3-methylimidazo[4,5-f]quinoxaline (IQx)， 2-amino-3,4-dimethylimidazo[4,5f]quinoline (MeIQ), 2-amino-3,8-dimethylimidazo[4,5-f]quinoxaline (MeIQx), 2amino-3,4,8-trimethylimidazo[4,5-f]quinoxaline $\quad(4,8-D i M e I Q x), \quad 2$-amino-3,7,8trimethylimidazo[4,5-f]quinoxaline $\quad$ (7,8-DiMeIQx), $\quad$ 2-amino-3,4,7,8tetramethylimidazo[4,5-f]quinoxaline $\quad$ (TriMeIQx), 2-amino-1-methyl-6phenylimidazo[4,5-b]pyridine (PhIP), 3-amino-1,4-dimethyl-5H-pyrido[4,3- $b]$ indole (Trp-P-1), 3-amino-1-methyl-5H-pyrido[4,3-b]indole $\quad$ (Trp-P-2), 2-amino-9H- 
pyrido[2,3-b]indole $(\mathrm{A} \alpha \mathrm{C}), 2$-amino-3-methyl-9H-pyrido[2,3-b]indole (MeA $\alpha \mathrm{C}), 2$ amino-6-methyldipyrido[1,2-a:3',2'-d]imidazole (Glu-P-1), and 2-aminodipyrido[1,2$\left.a: 3^{\prime}, 2^{\prime}-d\right]$ imidazole (Glu-P-2), were obtained from Toronto Research Chemicals (North York Ontario, Canada). Sodium hydroxide, ammonium acetate and ammonia solution $25 \%(\mathrm{v} / \mathrm{v})$ used for HAs quantification were obtained from Merck. Triethylamine from Fisher Scientific (Pittsburgh, PA,USA), hydrochloric acid from Panreac (Barcelona, Spain). Extrelut reservoirs and Extrelut HM-N diatomaceous earth refill material were obtained from Merck. Bond Elut PRS (500 mg) and endcapped Bond Elut C18 (100 and $500 \mathrm{mg}$ ) cartridges were from Agilent Technologies (USA).

Supelco Visiprep and a Visidry SPE vacuum manifold (Supelco) were used to aid in the extraction of PAHs and HAs.

\subsection{RWPS preparation}

RWPS was obtained from dehydrated seedless red wine pomace (González San José et al., 2015), whose chemical composition (dietary fiber, fat, protein, minerals and phenolic classes) as well antimicrobial and antioxidant activities have been previously reported (García-Lomillo et al., 2014).The seasoning was milled (particle size less than $250 \mu \mathrm{m}$ mesh) and kept in dark until its use.

\subsection{Patty preparation and cooking}

Beef meat was obtained from a local supplier (GrosMercat, Burgos, Spain). Ingredients and additives included in the formulation (common salt, food grade starch and a commercially available mixture of phosphates) were provided by Doscadesa (Murcia, Spain). Beef meat was ground in a food mixer and additives were added according to the following formulation: $920 \mathrm{~g}$ of meat $12 \mathrm{~g}$ of starch, $15 \mathrm{~g}$ of salt and 3 $\mathrm{g}$ of phosphates and $50 \mathrm{~mL}$ of water. In the case of RWPS samples, $20 \mathrm{~g}$ of the studied 
seasoning was added in a water suspension to obtain a final concentration of $2 \%(\mathrm{w} / \mathrm{w})$. Eight patties per treatment were manually formed with a thickness between 12 and 15 $\mathrm{mm}$ and a weight between 100 and $105 \mathrm{~g}$. The total patties were divided in 4 groups, control at 0 days, control at 9 days, RWPS treated at 0 days and RWPS treated at 9 days.

For storage, samples were placed in polyethylene/ethylene vinyl alcohol/polystyrene trays (Sanviplast, Barcelona, Spain), filled with a gas mixture (70\% $\mathrm{O}_{2} / 30 \% \quad \mathrm{CO}_{2}$ ), and sealed using a polyethylene terephthalate polyvinylidene chloride/polyethylene film and keept at $4^{\circ} \mathrm{C}$ during 9 days.

Wood charcoal for barbecue was ignited and the temperature was assed using a thermometer Crison $638 \mathrm{Pt}$ (Barcelona, Spain). When the temperature was $210^{\circ} \mathrm{C}$, samples were placed at $8 \mathrm{~cm}$ of distance from the heat source. Temperature in the patties inner was monitored during the total barbecuing time (seven minutes). Samples were turned once at the half time of barbecuing. Charcoal was replaced between different samples. Raw and barbecued patties were weighed and the cooking loss was evaluated according to equation 1:

$$
\text { Cooking loss }(\%)=\frac{\text { Weight }_{\text {raw }}-\text { Weight }_{\text {cooked }}}{\text { Weight }_{\text {raw }}} * 100
$$

Four patties were mixed, homogenized and frozen at $-80^{\circ} \mathrm{C}$. Half of the sample was kept frozen for HAs analysis, whereas the other half were freeze-dried for PAHs analysis. Samples for PAHs analysis were protected from light with aluminum paper. Two independent replicates (consisting in 4 patties each replicate) were prepared, and cooked separately for each sample to take into account the inevitable variability between batches and cooking procedures. 
The chemical composition of the raw and cooked beef patties were analyzed using a FoodScan ${ }^{\mathrm{TM}}$ near-infrared spectrophotometer (Foss Electric A/S, Hillerød, Denmark) and the data processed by the ISIscan ${ }^{\mathrm{TM}}$ Software.

\subsection{ABTS assay}

The radical scavenger activity of raw patties was assessed according to the method described by Rivero-Pérez et al. (2007) adapted to meat samples. The day before analysis, the ABTS reagent was prepared by mixing ABTS solution and $\mathrm{K}_{2} \mathrm{O}_{8} \mathrm{~S}_{2}$ in mili Q water (1:1). For the analysis, $75 \pm 2 \mathrm{mg}$ of raw patty were mixed with $15 \mathrm{~mL}$ of the solution of ABTS reagent and conventionally vortexed. After 30 minutes of reaction with agitation, the radical scavenger activity was evaluated by measuring the decrease in the absorbance at $734 \mathrm{~nm}$ during the 30 minutes of reaction. A standard calibration was conducted using trolox as standard and results were expressed as $\mu$ mol of trolox / g of patty.

\subsection{Extraction and quantification of PAHs}

PAHs were extracted, separated and quantified according to the method described by Viegas et al. (2012b). Briefly, two grams of freeze-dried sample were subjected to ultrasound-assisted solvent extraction with $20 \mathrm{~mL}$ of $\mathrm{n}$-hexane for $1 \mathrm{~h}$ at room temperature. The suspension was then filtrated and dried with a rotatory evaporator. The residue was resuspended and transferred to a $5 \mathrm{~g}$ silica cartridge (Mega BE-Si, 5g, 20ml, from Agilent Technologies, USA). PAHs were eluted from the cartridge with $24 \mathrm{~mL}$ of $\mathrm{n}$-hexane/dichloromethane $(70: 30, \mathrm{v} / \mathrm{v})$. The resulting solution was evaporated to dryness under nitrogen stream at room temperature and the residue was re-dissolved in $100 \mu \mathrm{L}$ of acetonitrile. 
The separation was carried out using a HPLC unit (Jasco, Japan) equipped with one PU-1580 HPLC pump, an AS-950 auto sampler with a $20 \mu \mathrm{L}$ loop and a FP-920 fluorescence detector. The system was fully controlled by Borwin PDA Controller Software (JMBS Developments, Le Fontanil, France). The column was a C18 Supelcosil LC-PAH (25 cm length; $4.6 \mathrm{~mm}$ internal diameter, $5 \mu \mathrm{m}$ particle size) (Supelco, Bellefonte, PA, USA) thermostated at $32^{\circ} \mathrm{C}$. Mobile phase were composed by three solvents: $75 \%$ methanol in water (A), methanol (B) and ethyl acetate $(\mathrm{C})$ with the follow linear gradient: $0-18 \mathrm{~min}, 0-80 \% \mathrm{~B}$ in $\mathrm{A} ; 18-19 \mathrm{~min}, 80-100 \% \mathrm{~B}$ in $\mathrm{A} ; 19-20$ $\min , 100-90 \%$ B in C; $20-28,5 \min , 90-82 \%$ B in C; $28,5-37,5$ min, $82-80 \%$ B in C; 37,5-40 $\mathrm{min}, 80-100 \% \mathrm{~B}$ in $\mathrm{C}, 40-45 \mathrm{~min} 100-0 \% \mathrm{~B}$ in a flow rate of $1 \mathrm{ml} / \mathrm{min}$. Fluorescence detector set up with the following excitation/emission wavelengths: 276/330 nm for naphthalene, acenaphthene, fluorene; 250/336 nm for phenanthrene; 250/402 nm for A; 270/460 nm for FA; 270/390 nm for PYR, BaA and CHR; 260/430 nm for BbFA; 290/410 nm for BkFA, BaP, BDahA, and BhigP; 290/470 nm for IP. Peak identification was carried out based on retention times of standard solution peaks. For quantification, standard additions were conducted at two fortification levels (10-20 $\mathrm{ng} / \mathrm{g})$.

\subsection{Extraction and quantification of HAs}

HAs were extracted and purified using the reference method in interlaboratorial exercises (Santos et al., 2004). Briefly, sample (5 g) was homogenized in $15 \mathrm{~mL}$ of $1 \mathrm{M}$ $\mathrm{NaOH}$ with sonication (10 min) followed by one hour of shaking using a Vortex Mixer VV3 (VWR International, West Chester, PA, USA). The resulting solution was mixed with diatomaceous earth (16 g) and used to fill an empty Extrelut 20 column (Extrelut ${ }^{\circledR}$, Merck, Darmstadt, Germany), that was coupled to an a PRS SPE column (Bond Elut PRS, $500 \mathrm{mg}$ ). $75 \mathrm{~mL}$ of dichloromethane were passed through the tandem. 
Then, the washing solutions $(6 \mathrm{~mL}$ of $0.01 \mathrm{M} \mathrm{HCl}, 15 \mathrm{~mL}$ of $\mathrm{MeOH}, 0.1 \mathrm{M} \mathrm{HCl}$ (6:4, $\mathrm{v} / \mathrm{v}$ ), and $2 \mathrm{~mL}$ of water) were passed through the PRS cartridge. The eluted solution was neutralized with $500 \mu \mathrm{L}$ of ammonia solution and diluted with $25 \mathrm{~mL}$ of water prior to pass through the preconditioned C18 cartridge $(500 \mathrm{mg}$ ) for the analysis of $\mathrm{PhIP}$ and less polar compounds (A $\alpha \mathrm{C}, \mathrm{MeA} \alpha \mathrm{C}$, Trp-P-1, Trp-P-2). Finally, C18 cartridge was rinsed with $5 \mathrm{~mL}$ of water and HAs were eluted with $1.4 \mathrm{~mL}$ of methanol/ammonia solution (9:1, v/v). The most polar amines (Glu-P-1, Glu-P-2, IQ, MeIQ, MeIQx, 4,8-DiMeIQx, 7,8-DiMeIQx, PhIP) were eluted from the PRS cartridge using $20 \mathrm{~mL}$ of $0.5 \mathrm{M}$ ammonium acetate at $\mathrm{pH} 8.5$, to the preconditioned $100 \mathrm{mg}$ Bond Elut C18 cartridge coupled online. Finally, the C18 cartridge was rinsed with 5 $\mathrm{mL}$ of water, and the HAs were desorbed using $0.8 \mathrm{~mL}$ of methanol/ammonia solution $(9: 1, v / v)$. The extracts containing either the most or least polar analytes were gently evaporated under a stream of nitrogen, and re-dissolved in $80 \mu \mathrm{L}$ of methanol.

The separation of HAs were performed in the same HPLC unit (Jasco, Japan) than PAHs but also equipped with a diode array (MD 910 Multiwavelength detector) (HPLC-DAD/FLD). The column was a TSK gel ODS80 (Toyo Soda) $(5 \mu \mathrm{m} ; 250 \mathrm{~mm}$ length; $4.6 \mathrm{~mm}$ internal diameter). The mobile phase was as follows: solvent A, 0.01 M triethylamine adjusted with phosphoric acid to $\mathrm{pH} 3.2$; solvent $\mathrm{B}$, same as $\mathrm{A}$, but adjusted to $\mathrm{pH} 3.6$; solvent $\mathrm{C}$ acetonitrile. The linear gradient program was: 0-10 min, 5-15\% C in A, 10-10.1 min exchange of A with $\mathrm{B} ; 10.1-20$ min, $15-25 \% \mathrm{C}$ in $\mathrm{B} ; 20-$ $30 \mathrm{~min}, 25-55 \% \mathrm{C}$ in $\mathrm{B} ; 30-55 \mathrm{~min}$, column rinse and re-equilibration. DAD was set at

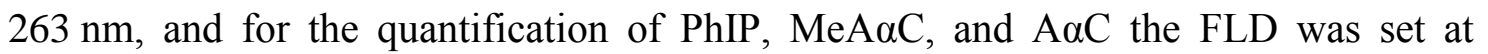
excitation $307 \mathrm{~nm}$ and emission at $370 \mathrm{~nm}$. Peak identification in food samples was carried out by comparing retention times and spectra of unknown peaks with reference standards. Standard addition method was used for quantification of HAs using the non- 
spiked sample and two fortified levels (5 and $10 \mathrm{ng} / \mathrm{g}$, for thermic HAs and 10 and $20 \mathrm{ng} / \mathrm{g}$ for pyrolytic HAs) before extraction procedure.

\subsection{Statistical analysis}

Two independent experiences with 4 patties per experience were prepared and cooked for each treatment. Furthermore, each replicate was extracted and quantified in triplicate. Fisher's least significant difference test ( $\mathrm{p}$-value $<0.05$ ) was performed in Statgraphics Centurion XVI version 16.2.04 (Statpoint Technologies, Inc., Warranton, VA, USA) to detect significant differences between treatments.

\section{RESULTS AND DISCUSSION}

\subsection{Effect of seasoning and storage on total antioxidant capacity of raw patties}

Control patties at day 0 presented a radical scavenger activity of $2.98 \pm 0.37$ $\mu \mathrm{mol} / \mathrm{g}$, whereas after the addition of RWPS it decreased to $1.99 \pm 0.27 \mu \mathrm{mol} / \mathrm{g}$. Del Pino-García et al. (2015) observed that RWPS presented high radical scavenger activity (120 $\pm 5 \mu \mathrm{mol} / \mathrm{g}$ of RWPS). However, RWPS blocks thiol groups of proteins, which are known to have a predominant role in the antioxidant activity of meat products (Garcia-Lomillo et al., 2016; Serpen et al., 2012), which could explain the decrease in the antioxidant activity of RWPS patties. Furthermore, RWPS may induce protein cross-linking of protein tissue, which could limit the release of some of the endogenous antioxidants from muscle tissue during the assay (Nirmal \& Benjakul, 2011).

After 9 days of storage, opposite results were observed. Control samples decreased their radical scavenger activity $(1.89 \pm 0.41 \mu \mathrm{mol} / \mathrm{g})$, most likely due to the depletion of endogenous antioxidants such as thiols groups or vitamin E during storage. In contrast, patties with RWPS exhibited higher radical scavenger activity $(2.89 \pm 0.40$ $\mu \mathrm{mol} / \mathrm{g}$ ), presenting higher values than control samples, and very similar to control at 0 
days. This fact could be explained by the release of phenolic compounds from RWPS matrix during the storage and the protective effect of grape polyphenols on the endogenous chain-braking antioxidants (vitamin $\mathrm{E}$, vitamin $\mathrm{C}$, thiol groups, amine groups or enzymes) (Pazos et al., 2005). Marchiani et al. (2016) also observed a gradual release of quercetin during storage of yogurt enriched with grape pomace.

\subsection{Patty composition, cooking temperature and cooking loss}

The incorporation of RWPS did not affect moisture, protein and lipid contents of either raw or cooked patties. Significant differences were not observed between samples cooked at 0 day and at 9 day (Table 7.1.). The inner temperature at the end of the cooking was around $83^{\circ} \mathrm{C}$ and no significant differences were observed in the temperature profile between control and RWPS samples at 0 and 9 days. The cooking loss averaged $29.8 \%$, without significant differences between the different treatments. These results are within the range reported for beef patties (U.S. Department of Agriculture, 2012), but lower than other products such as beef steaks or pork loin that ranged between $40 \%$ and $48 \%$ (Viegas et al., 2012c). The use of salt, starch and phosphates increases the water holding capacity and reduces cooking loss (Sebranek, 2009), which can explain the low levels of cooking loss observed in the present study.

\subsection{Effect of RWPS on PAHs formation in barbecued beef patties}

\section{before and after storage}

The PAH8 (EFSA, 2008), as well as A, FA, PYR were quantified in all samples (Table 7.2.). The levels were low, but within the range reported previously for beefsteaks (Viegas et al., 2012b; Viegas et al., 2012c). The fat content is an extremely important parameter for PAHs formation in charcoal grilled muscle foods. Beef is known to form lower amount of PAHs compared with pork, chicken and salmon 
(Viegas et al., 2012c; Viegas et al., 2014). Chung et al. (2011) compared the formation of PAHs in pork and beef meat, and observed PAHs formation in charcoal grilled beef samples similar to obtained in our study, and highlighted that pork meat produces relatively higher values. PAHs formation is related to drippings juices from meat to the charcoal bed and exposition time, the low cooking losses and short cooking time of patties may explain the low level of PAHs found.

Table 7.1. Chemical composition and cooking loss of beef patties raw and cooked without red wine pomace seasoning (control) or with red wine pomace seasoning (RWPS).

\begin{tabular}{|c|c|cc|cc|}
\cline { 2 - 6 } \multicolumn{1}{c|}{} & \multirow{2}{*}{\begin{tabular}{c} 
Raw \\
\multicolumn{1}{c|}{}
\end{tabular}} & \multicolumn{4}{c|}{ Cooked patties } \\
\cline { 3 - 6 } & patties & \multicolumn{2}{c|}{ Control } & \multicolumn{2}{c|}{ RWPS } \\
Day 0 & Day 9 & \multicolumn{1}{c|}{ Day 0 } & Day 9 \\
\hline Moisture (\%) & $64.2 \pm 0.6$ & $57.0 \pm 1.5$ & $57.0 \pm 0.3$ & $57.3 \pm 0.3$ & $57.9 \pm 1.2$ \\
Protein (\%) & $18.3 \pm 0.3$ & $22.6 \pm 1.5$ & $21.3 \pm 0.9$ & $21.7 \pm 0.8$ & $20.6 \pm 1.4$ \\
Lipid (\%) & $12.4 \pm 0.8$ & $9.7 \pm 0.8$ & $11.7 \pm 1.5$ & $11.0 \pm 0.8$ & $10.5 \pm 0.8$ \\
\hline Cooking loss (\%) & & $28.6 \pm 1.9$ & $29.2 \pm 2.0$ & $30.7 \pm 3.0$ & $30.7 \pm 1.9$ \\
\hline
\end{tabular}

${ }^{a}$ Results are presented as the mean \pm standard deviation. No significant differences were observed between cooked samples at a p-value $<0.05$.

At day 0, RWPS patties presented significantly higher values of A, FA, PYR, CHR, BbFA, BaP and IP than control (Table 7.2.). These results were surprising since antioxidants and spices were reported to mitigate the formation of PAHs (Janoszka, 2011; Viegas et al., 2014). However, RWPS patties at day 0 presented lower scavenging activity against ABTS radical than the corresponding control. Since PAHs formation seems to be mediated by free-radical chain, the lower scavenging activity observed in RWPS patties may explain the higher value of PAHs compared with control. The pyrolysis of phenolic compounds may contribute to the higher PAHs measured in RWPS patties. Lignin, cellulose and pectin may also render PAHs under 
pyrolytic conditions (McGrath et al., 2001; Sharma \& Hajaligol, 2003). The fact that RWPS is a complex product with high levels of plant fiber and polyphenols (GarcíaLomillo et al., 2014) could explain the higher levels of PAHs measured in RWPS patties at 0 days.

Table 7.2. PAHs content in barbecued beef patties without seasoning (control) and with seasoning $(2 \% \mathrm{w} / \mathrm{w})$ at day 0 and day 9 storage at high-oxygen atmosphere. ${ }^{\text {a }}$

\begin{tabular}{cccc}
\hline \multicolumn{2}{c}{ Control Patties } & \multicolumn{2}{c}{ RWPS patties } \\
\cline { 2 - 5 } Day 0 & Day 9 & Day 0 & Day 9 \\
\hline
\end{tabular}

\section{Light PAHs}
A
$0.86 \pm 0.26 \mathrm{a}$
$1.37 \pm 0.61 \mathrm{a}$
$2.28 \pm 0.41 b$
$0.71 \pm 0.09 \mathrm{a}$

\section{Heavy PAHs}

\begin{tabular}{ccccc} 
FA & $3.35 \pm 0.47 \mathrm{a}$ & $7.36 \pm 1.47 \mathrm{c}$ & $5.42 \pm 0.56 \mathrm{~b}$ & $3.20 \pm 0.47 \mathrm{a}$ \\
PYR & $3.04 \pm 0.85 \mathrm{a}$ & $4.28 \pm 0.36 \mathrm{~b}$ & $5.10 \pm 0.31 \mathrm{~b}$ & $2.40 \pm 0.34 \mathrm{a}$ \\
BaA & $0.42 \pm 0.12 \mathrm{a}$ & $0.51 \pm 0.06 \mathrm{a}, \mathrm{b}$ & $0.66 \pm 0.11 \mathrm{~b}$ & $0.32 \pm 0.17 \mathrm{a}$ \\
CHR & $0.63 \pm 0.11 \mathrm{a}, \mathrm{b}$ & $0.76 \pm 0.16 \mathrm{~b}$ & $1.30 \pm 0.07 \mathrm{c}$ & $0.54 \pm 0.15 \mathrm{a}$ \\
BbFA & $0.30 \pm 0.13 \mathrm{a}$ & $0.55 \pm 0.10 \mathrm{~b}$ & $0.53 \pm 0.12 \mathrm{~b}$ & $0.37 \pm 0.20 \mathrm{a}, \mathrm{b}$ \\
BkFA & $0.19 \pm 0.07$ & $0.18 \pm 0.01$ & $0.18 \pm 0.03$ & $0.18 \pm 0.06$ \\
BaP & $0.22 \pm 0.09 \mathrm{a}$ & $0.20 \pm 0.05 \mathrm{a}$ & $0.34 \pm 0.11 \mathrm{~b}$ & $0.23 \pm 0.07 \mathrm{a}, \mathrm{b}$ \\
DBahA & $0.21 \pm 0.06$ & $0.20 \pm 0.01$ & $0.18 \pm 0.05$ & $0.17 \pm 0.05$ \\
BghiP & $0.30 \pm 0.11$ & $0.34 \pm 0.13$ & $0.32 \pm 0.07$ & $0.24 \pm 0.13$ \\
IP & $0.15 \pm 0.04 \mathrm{a}$ & $0.24 \pm 0.02 \mathrm{a}, \mathrm{b}$ & $0.33 \pm 0.08 \mathrm{~b}$ & $0.43 \pm 0.07 \mathrm{c}$ \\
\hline PAHs & $\mathbf{9 . 6 7} \pm \mathbf{2 . 1 2} \mathbf{a}$ & $\mathbf{1 5 . 9 8} \pm \mathbf{1 . 6 3} \mathbf{b}$ & $\mathbf{1 6 . 6 3} \pm \mathbf{0 . 9 9} \mathbf{b}$ & $\mathbf{8 . 7 9} \pm \mathbf{1 . 4 0} \mathbf{a}$
\end{tabular}

${ }^{\mathrm{a}}$ Results are presented as the mean \pm standard deviation. Means with different letters in the same row represent values significantly different ( $\mathrm{p}$ value $<0.05$ ).

Control samples cooked after 9 days of storage presented an increase of PAHs content compared with patties cooked at 0 day, being the differences significant for FA, PYR and BbFA. The depletion of endogenous antioxidants from meat during storage, 
observed through the lower ABTS values, explains the decreased scavenge capacity of meat against the radicals derived from the pyrolytic reaction resulting in higher PAHs formation. Furthermore, conjugated dienes, formed during lipid oxidation, may directly undergo dimerization and polymerization leading to the formation of PAHs via DielsAlder type reactions (Nawar, 1984).

No information was found concerning effect of storage on PAHs formation, however, Szterk \& Waszkiewicz-Robak (2014) demonstrated that the longer the raw meat was stored, the more HAs was formed during grilling, through the higher content of free amino acids. RWPS patties grilled after 9 days of storage presented lower levels than stored control samples, although significant reduction (between 29 and $51 \%$ ) was observed only for FA, PYR, and CHR. Comparison between RWPS patties cooked at 0 and 9 days, stored samples presented lower levels of A, FA, PYR, BaA, CHR and IP. Then, a period may be required for the polyphenols to exert their action, since at 0 day ABTS from RWPS patties was $1.99 \pm 0.27 \mu \mathrm{mol} / \mathrm{g}$ increasing to $2.89 \pm 0.40 \mu \mathrm{mol} / \mathrm{g}$ at 9 days. Furthermore, the seasoning is known to retard lipid oxidation and to protect the endogenous antioxidants during the storage at high-oxygen atmosphere (GarciaLomillo et al., 2016; García-Lomillo et al., 2014). Lipid content is closely related with PAHs formation, and preventing its oxidation may inhibit PAHs formation.

\subsection{Effect of RWPS on HAs formation in barbecued beef patties before}

\section{and after storage}

Among the 5 apolar HAs and the 7 polar HAs evaluated in the present study, only two HAs (PhIP and $\mathrm{A} \alpha \mathrm{C}$ ) were detected above the limit of detection in all the samples (Table 7.3.). Furthermore, MeA- $\alpha-C$ was also detected in patties cooked with RWPS at 0 day and control samples at 9 day of storage, but not in other samples (Table 7.3.). The 
levels of PhIP and $\mathrm{A} \alpha \mathrm{C}$ found in the present study are within the range reported by Szterk et al. (2012) in beef samples. Other authors also detected very low amounts of HAs, such as Polak et al. (2009) that only detected MeIQx and PhIP in grilled beef steaks. The low formation of HAs in the present study agrees with the fact that beef meat form lower amounts of HAs than other muscles foods such as chicken or salmon (Viegas et al., 2012c). Additionally, the low cooking loss limits the transfer of precursors to the patty surface where HAs are more abundantly formed (Skog et al., 1998). The use of starch, salt and phosphate may restrict the transport of precursors towards the surface during cooking (Borgen \& Skog, 2004; Persson et al., 2003). The short cooking time ( 4 min each side) and the relatively high thickness of beef patties (10 mm), also explain the observed low HAs formation in this meat product. Costa et al. (2009) evaluated the effect of cooking time in HAs formation in charcoal grilled sardines, and observed that no HAs were detected in samples cooked 5 minutes each side even at $280 / 300{ }^{\circ} \mathrm{C}$.

Table 7.3. HAs content (ng/g) in barbecued beef patties without seasoning (control) and with seasoning $(2 \% \mathrm{w} / \mathrm{w})$ at day 0 and day 9 storage at high-oxygen atmosphere. ${ }^{\mathrm{a}}$

\begin{tabular}{|c|cc|cc|}
\hline \multirow{2}{*}{ HAs } & \multicolumn{2}{|c|}{ Control Patties } & \multicolumn{2}{c|}{ RWPS Patties } \\
& Day 0 & Day 9 & Day 0 & Day 9 \\
\hline PhIP & $0.86 \pm 0.22 \mathrm{a}, \mathrm{b}$ & $0.68 \pm 0.33 \mathrm{a}$ & $1.16 \pm 0.42 \mathrm{~b}$ & $0.69 \pm 0.17 \mathrm{a}$ \\
A $\boldsymbol{\alpha C}$ & $0.33 \pm 0.08 \mathrm{a}, \mathrm{b}$ & $0.24 \pm 0.02 \mathrm{a}$ & $0.49 \pm 0.17 \mathrm{~b}$ & $0.38 \pm 0.18 \mathrm{a}, \mathrm{b}$ \\
MeAC & n.q. & n.d. & $0.29 \pm 0.12$ & n.d. \\
\hline
\end{tabular}

${ }^{a}$ Results are presented as the mean \pm standard deviation. Means with different letters in the same row are significantly different ( $\mathrm{p}$ value $<0.05)$.n.d.: not detected $(<0.02 \mathrm{ng} / \mathrm{g})$; n.q: not quantifiable $(<0.25 \mathrm{ng} / \mathrm{g})$. LOQ and LOD were previously determined (Melo et al., 2008) 
Charcoal grilling creates a very dry environment, especially when samples are grilled near the heat source. PhIP and $\mathrm{A} \alpha \mathrm{C}$ formation are favored by higher temperatures and dry environment, in opposite this conditions are disadvantageous to MeIQx and other thermic HAs formation (Skog et al., 2000). Persson et al. (2003) also observed that the addition of $\mathrm{NaCl} /$ sodium tripolyphosphate to the beefburgers reduced the cooking loss and decreased the formation of PhIP, MeIQx, and 4,8-DiMeIQx. This decrease was significant for MeIQx and 4,8-DiMeIQx, that may explain the absence of detection of these HAs in our samples. Starch added to the beef patties inhibited mutagenic activity by up to $54 \%$ (Skog et al., 1992). These factors may explain why MeIQx, a relevant HA found in beef meat was not found in our samples.

At day 0, RWPS patties showed higher contents of PhIP, $\mathrm{A} \alpha \mathrm{C}$ and $\mathrm{MeAC}$ than control, although the difference was not significant. Control samples cooked after 9 days of storage presented very similar values than samples at the beginning of the storage (Table 7.3.). As in the case of PAHs, RWPS patties at 9 days also present similar values than control patties and lower content than RWPS patties at day 0 . These results agree with the results from ABTS test as described previously. The increased antioxidant activity observed during storage of RWPS patties may explain the HAs inhibition observed after 9 days of storage. Some studies have correlated the inhibition exerted by natural antioxidants with their radical scavenging activity (Gibis, 2016; Kikugawa, 1999; Shin, 2005). In contrast, other authors did not find significant correlations, which suggests that other mechanisms may be involved in the inhibition provided (Cheng et al., 2007; Viegas et al., 2012a). 


\section{CONCLUSIONS}

Low levels of PAHs and HAs were found in beef patties, most likely due to the use of additives that may decrease the cooking loss. Nine days of storage increased PAHs formation ( $\sum$ PAHs $15.16 \mathrm{ng} / \mathrm{g}$ ) in barbecued patties compared with control samples at 0 days ( $\sum$ PAHs $9.67 \mathrm{ng} / \mathrm{g}$ ). RWPS patties with 9 days of storage presented similar PAHs levels ( $\sum$ PAHs $8.79 \mathrm{ng} / \mathrm{g}$ ) to those found initially for control patties. These results agree with the ABTS radical scavenging activity of raw samples, which may suggest that the radical chain reactions have a predominant role in the formation of PAHs. The other major carcinogenic of cooked meat HAs was also evaluated, lower levels of these compounds were quantified and no significant effect was observed in their formation after 9 days of storage, which was not surprising since this type of meat product does not promote HAs formation.

The addition of RWPS during the storage at high-oxygen atmosphere increases the scavenging capacity and protects the endogenous antioxidants of meat, preventing the formation of PAHs and also HAs, and maintaining the meat preserved and with less meat cooking carcinogens.

\section{REFERENCES}

Ahn, J., \& Grün, I. U. (2005). Heterocyclic amines: 2. Inhibitory effects of natural extracts on the formation of polar and nonpolar heterocyclic amines in cooked beef. Journal of Food Science, 70(4), C263-C268.

Borgen, E., \& Skog, K. (2004). Heterocyclic amines in some Swedish cooked foods industrially prepared or from fast food outlets and restaurants. Molecular Nutrition and Food Research, 48(4), 292-298.

Bouvard, V., Loomis, D., Guyton, K. Z., Grosse, Y., Ghissassi, F. E., BenbrahimTallaa, L., Guha, N., Mattock, H., \& Straif, K. (2015). Carcinogenicity of consumption of red and processed meat. The Lancet Oncology, 16(16), 15991600 .

Busquets, R., Puignou, L., Galceran, M. T., \& Skog, K. (2006). Effect of Red Wine Marinades on the Formation of Heterocyclic Amines in Fried Chicken Breast. Journal of Agricultural and Food Chemistry, 54(21), 8376-8384. 
Costa, M., Viegas, O., Melo, A., Petisca, C., Pinho, O., \& Ferreira, I. M. P. L. V. O. (2009). Heterocyclic Aromatic Amine Formation in Barbecued Sardines (Sardina pilchardus) and Atlantic Salmon (Salmo salar). Journal of Agricultural and Food Chemistry, 57(8), 3173-3179.

Chen, B. H., \& Chen, Y. C. (2001). Formation of polycyclic aromatic hydrocarbons in the smoke from heated model lipids and food lipids. Journal of Agricultural and Food Chemistry, 49(11), 5238-5243.

Cheng, K.-W., Chen, F., \& Wang, M. (2007). Inhibitory activities of dietary phenolic compounds on heterocyclic amine formation in both chemical model system and beef patties. Molecular Nutrition \& Food Research, 51(8), 969-976.

Chung, S. Y., Yettella, R. R., Kim, J. S., Kwon, K., Kim, M. C., \& Min, D. B. (2011). Effects of grilling and roasting on the levels of polycyclic aromatic hydrocarbons in beef and pork. Food Chemistry, 129(4), 1420-1426.

Del Pino-García, R., García-Lomillo, J., Rivero-Pérez, M. D., González-Sanjosé, M. L., \& Muñiz, P. (2015). Adaptation and Validation of QUick, Easy, New, CHEap, and Reproducible (QUENCHER) Antioxidant Capacity Assays in Model Products Obtained from Residual Wine Pomace. Journal of Agricultural and Food Chemistry, 63(31), 6922-6931.

Del Pino-García, R., Gerardi, G., Rivero-Pérez, M. D., González-SanJosé, M. L., García-Lomillo, J., \& Muñiz, P. (2016). Wine pomace seasoning attenuates hyperglycaemia-induced endothelial dysfunction and oxidative damage in endothelial cells. Journal of Functional Foods, 22, 431-445.

EFSA. (2008). Scientific opinion of the panel on contaminants in the food chain on a request from the European Commission on polycyclic aromatic hydrocarbons in food. EFSA Journal, 724, 1-114.

Garcia-Lomillo, J., González-SanJosé, M., Skibsted, L., \& Jongberg, S. (2016). Effect of Skin Wine Pomace and Sulfite on Protein Oxidation in Beef Patties During High Oxygen Atmosphere Storage. Food and Bioprocess Technology, 9(3), 532-542.

García-Lomillo, J., González-SanJosé, M. L., Del Pino-García, R., Rivero-Pérez, M. D., \& Muñiz-Rodríguez, P. (2014). Antioxidant and antimicrobial properties of wine byproducts and their potential uses in the food industry. Journal of Agricultural and Food Chemistry, 62(52), 12595-12602.

Gibis, M. (2016). Heterocyclic Aromatic Amines in Cooked Meat Products: Causes, Formation, Occurrence, and Risk Assessment. Comprehensive Reviews in Food Science and Food Safety, 15(2), 269-302.

González San José, M. L., García Lomillo, J., Del Pino García, R., Dolores Rivero, M., \& Muñiz Rodríguez, P. (2015). Sazonador de origen vegetal con propiedades conservantes, sustitutivo de la sal, y procedimiento de obtención del mismo. ES2524870 B2. Spain.

Janoszka, B. (2011). HPLC-fluorescence analysis of polycyclic aromatic hydrocarbons (PAHs) in pork meat and its gravy fried without additives and in the presence of onion and garlic. Food Chemistry, 126(3), 1344-1353. 
Kikugawa, K. (1999). Involvement of free radicals in the formation of heterocyclic amines and prevention by antioxidants. Cancer Letters, 143(2), 123-126.

Lee, J.-G., Kim, S.-Y., Moon, J.-S., Kim, S.-H., Kang, D.-H., \& Yoon, H.-J. (2016). Effects of grilling procedures on levels of polycyclic aromatic hydrocarbons in grilled meats. Food Chemistry, 199, 632-638.

Marchiani, R., Bertolino, M., Belviso, S., Giordano, M., Ghirardello, D., Torri, L., Piochi, M., \& Zeppa, G. (2016). Yogurt Enrichment with Grape Pomace: Effect of Grape Cultivar on Physicochemical, Microbiological and Sensory Properties. Journal of Food Quality, 39, 77-89.

McGrath, T., Sharma, R., \& Hajaligol, M. (2001). An experimental investigation into the formation of polycyclic-aromatic hydrocarbons (PAH) from pyrolysis of biomass materials. Fuel, 80(12), 1787-1797.

Melo, A., Viegas, O., Petisca, C., Pinho, O., \& Ferreira, I. M. P. L. V. (2008). Effect of beer/red wine marinades on the formation of heterocyclic aromatic amines in pan-fried beef. Journal of Agricultural and Food Chemistry, 56(22), 1062510632.

Nawar, W. W. (1984). Chemical changes in lipids produced by thermal processing. Journal of Chemical Education, 61(4), 299.

Nirmal, N. P., \& Benjakul, S. (2011). Use of tea extracts for inhibition of polyphenoloxidase and retardation of quality loss of Pacific white shrimp during iced storage. Lwt-Food Science and Technology, 44(4), 924-932.

Pazos, M., González, M. J., Gallardo, J. M., Torres, J. L., \& Medina, I. (2005). Preservation of the endogenous antioxidant system of fish muscle by grape polyphenols during frozen storage. European Food Research and Technology, 220(5-6), 514-519.

Persson, E., Graziani, G., Ferracane, R., Fogliano, V., \& Skog, K. (2003). Influence of antioxidants in virgin olive oil on the formation of heterocyclic amines in fried beefburgers. Food and Chemical Toxicology, 41(11), 1587-1597.

Polak, T., Andrenšek, S., Žlender, B., \& Gašperlin, L. (2009). Effects of ageing and low internal temperature of grilling on the formation of heterocyclic amines in beef Longissimus dorsi muscle. LWT - Food Science and Technology, 42(1), 256-264.

Rivero-Pérez, M. D., Muñiz, P., \& González-Sanjosé, M. L. (2007). Antioxidant profile of red wines evaluated by total antioxidant capacity, scavenger activity, and biomarkers of oxidative stress methodologies. Journal of Agricultural and Food Chemistry, 55(14), 5476-5483.

Santos, F. J., Barceló-Barrachina, E., Toribio, F., Puignou, L., Galceran, M. T., Persson, E., Skog, K., Messner, C., Murkovic, M., Nabinger, U., \& Ristic, A. (2004). Analysis of heterocyclic amines in food products: interlaboratory studies. Journal of Chromatography B, 802(1), 69-78.

Sebranek, J. G. (2009). Basic Curing Ingredients. R. Tarté (Ed.), Ingredients in Meat Products: Properties, Functionality and Applications, (pp. 1-23). New York, NY: Springer New York. 
Serpen, A., Gökmen, V., \& Fogliano, V. (2012). Total antioxidant capacities of raw and cooked meats. Meat Science, 90(1), 60-65.

Sharma, R. K., Chan, W. G., \& Hajaligol, M. R. (2006). Product compositions from pyrolysis of some aliphatic $\alpha$-amino acids. Journal of Analytical and Applied Pyrolysis, 75(2), 69-81.

Sharma, R. K., \& Hajaligol, M. R. (2003). Effect of pyrolysis conditions on the formation of polycyclic aromatic hydrocarbons (PAHs) from polyphenolic compounds. Journal of Analytical and Applied Pyrolysis, 66(1-2), 123-144.

Shin, H. S. (2005). Influence of food ingredients on the formation of heterocyclic aromatic amine in cooked pork patties. Food Science and Biotechnology, 14(5), $572-575$.

Skog, K. I., Jägerstad, M., \& Laser Reuterswärd, A. (1992). Inhibitory effect of carbohydrates on the formation of mutagens in fried beef patties. Food and Chemical Toxicology, 30(8), 681-688.

Skog, K. I., Johansson, M. A. E., \& Jägerstad, M. I. (1998). Carcinogenic Heterocyclic Amines in Model Systems and Cooked Foods: A Review on Formation, Occurrence and Intake. Food and Chemical Toxicology, 36(9-10), 879-896.

Skog, K. I., Solyakov, A., \& Jägerstad, M. (2000). Effects of heating conditions and additives on the formation of heterocyclic amines with reference to aminocarbolines in a meat juice model system. Food Chemistry, 68(3), 299-308.

Szterk, A., Roszko, M., Małek, K., Kurek, M., Zbieć, M., \& Waszkiewicz-Robak, B. (2012). Profiles and concentrations of heterocyclic aromatic amines formed in beef during various heat treatments depend on the time of ripening and muscle type. Meat Science, 92(4), 587-595.

Szterk, A., \& Waszkiewicz-Robak, B. (2014). Influence of selected quality factors of beef on the profile and the quantity of heterocyclic aromatic amines during processing at high temperature. Meat Science, 96(3), 1177-1184.

U.S. Department of Agriculture, A. R. S. (2012). USDA Table of Cooking Yields for Meat and Poultry. In): Nutrient Data Laboratory Home Page: http://www.ars.usda.gov/nutrientdata.

Viegas, O., Amaro, L. F., Ferreira, I. M. P. L. V. O., \& Pinho, O. (2012a). Inhibitory effect of antioxidant-rich marinades on the formation of heterocyclic aromatic amines in pan-fried beef. Journal of Agricultural and Food Chemistry, 60(24), 6235-6240.

Viegas, O., Moreira, P. S., \& Ferreira, I. M. P. L. V. O. (2015). Influence of beer marinades on the reduction of carcinogenic heterocyclic aromatic amines in charcoal-grilled pork meat. Food Additives and Contaminants - Part A Chemistry, Analysis, Control, Exposure and Risk Assessment, 32(3), 315-323.

Viegas, O., Novo, P., Pinho, O., \& Ferreira, I. M. P. L. V. O. (2012b). A comparison of the extraction procedures and quantification methods for the chromatographic determination of polycyclic aromatic hydrocarbons in charcoal grilled meat and fish. Talanta, 88, 677-683. 
Viegas, O., Novo, P., Pinto, E., Pinho, O., \& Ferreira, I. M. P. L. V. O. (2012c). Effect of charcoal types and grilling conditions on formation of heterocyclic aromatic amines (HAs) and polycyclic aromatic hydrocarbons (PAHs) in grilled muscle foods. Food and Chemical Toxicology, 50(6), 2128-2134.

Viegas, O., Yebra-Pimentel, I., Martínez-Carballo, E., Simal-Gandara, J., \& Ferreira, I. M. P. L. V. O. (2014). Effect of Beer Marinades on Formation of Polycyclic Aromatic Hydrocarbons in Charcoal-Grilled Pork. Journal of Agricultural and Food Chemistry, 62(12), 2638-2643.

Yebra-Pimentel, I., Fernández-González, R., Martínez-Carballo, E., \& Simal-Gándara, J. (2015). A Critical Review about the Health Risk Assessment of PAHs and Their Metabolites in Foods. Critical Reviews in Food Science and Nutrition, 55(10), 1383-1405. 


\section{Chapter 8:}

EfFect of a New Natural SEasoning ON THE Formation OF PyRAZINES IN BARBECUED BeEF PATTIES 



\section{Presentación}

Las pirazinas son compuestos derivados de la reacción de Maillard que se forman durante el procesado de los alimentos a altas temperaturas. Son compuestos con impacto positivo porque aportan notas aromáticas de tostado, asado, etc., altamente apreciadas por los consumidores.

Dado que la incorporación de productos procedentes de la uva con alto contenido en antioxidantes podría interferir en la formación de las pirazinas (capítulo 1), se consideró interesante evaluar el efecto del sazonador procedente del orujo libre de pepitas sobre la formación de pirazinas en hamburguesas cocinadas en la barbacoa.

\section{Resultados más relevantes}

Las hamburguesas elaboradas con el sazonador mostraron niveles superiores de todas las pirazinas estudiadas en comparación con las hamburguesas control. La 2,5dimetilpirazina fue la que se encontró en mayor proporción, aunque debido al bajo valor umbral, 2-etil-5-metilpyrazina fue la que presentó mayor relevancia en el perfil olfativo. Los resultados de la nariz electrónica mostraron resultados concordantes con los mayores niveles de pirazinas, observándose mayor intensidad en las respuestas de los sensores relacionados con los olores de tostado.

Los resultados obtenidos se han asociado principalmente con la capacidad antioxidante del sazonador que favorece la reducción de metales, así como con la formación de quinonas, procedentes de los fenoles del sazonador, que pueden participar en la formación de pirazinas. 



\title{
Chapter 8: Effect of a New Natural Seasoning on the Formation
}

\section{of Pyrazines in Barbecued Beef Patties}

\begin{abstract}
The formation of pyrazines in food cooking is required to obtain satisfactory "roasted" flavor. The aim of this work was to evaluate the effect of a new red wine pomace seasoning (RWPS) on the formation of pyrazines in barbecued beef patties. Five pyrazines were successfully identified, being 2,5-dimethylpyrazine the most abundant. Although 2-ethyl-5-methylpyrazine was in lower levels, it presented the highest odor units, due to its low threshold. RWPS enhanced the formation of the five identified pyrazines (2.1 times), without relevant changes in the proportion between them. The highest increase was observed for 2-ethyl-6-methylpyrazine (3 times higher than in control). These results were corroborated by electronic nose analysis, presenting RWPS beef patties higher odor intensities. Mechanisms to explain these effects are also proposed in the present work, and the high content of polyphenols seems to be the major cause of the observed results. The use of RWPS could improve the flavor characteristics of meat products or enable using less intense cooking conditions with no changes in the flavor.
\end{abstract}

Accepted in Journal of Chemistry (In press) 


\section{INTRODUCTION}

Pyrazines is a class of heterocyclic compounds with two nitrogen atoms in para position with a major role in the "roast" flavor of foods. In this sense, pyrazines present a large impact on the flavor of cooked meat products, accounting for up to $80 \%$ of total volatiles (Mottram, 1985). Currently, pyrazines are included in the list of flavoring agents authorized by the European Union and are incorporated by the food industry to imitate meat flavors. Although some studies reported certain mutagenic activity of pyrazines (Müller \& Rappert, 2010), the concentration required is several orders of magnitudes higher than the normal intakes in Europe (EFSA, 2008).

The formation of pyrazines has been reported in frying, roasting, but not in boiled meat products (Jayasena et al., 2013). They are usually present in those products elaborated at high temperatures. Their odor threshold values are low and the most common associated odor notes are roasted nuts, coffee and chocolate flavors (Table 8.1.). (Mihara \& Masuda, 1988; Zhang et al., 2010) Due to the fact that the formation of pyrazines is required to achieve an optima sensory quality of roasted products, different research works have been conducted in order to ensure an adequate formation of this type of compounds and to optimize their final concentration (Farah et al., 2012; Jung et al., 1999). Many factors may affect the formation of pyrazines, such as temperature and duration of processing, $\mathrm{pH}$ or water content (Jayasena et al., 2013), and then several technological factors need to be taken into consideration in order to achieve an adequate level of pyrazines (Jiao et al., 2015; Pasqualone et al., 2014). Moreover, the ingredients of meat products should be considered (Jayasena et al., 2013; Pérez-Juan et al., 2008). 
Table 8.1. Pyrazines commonly found in meat products and their published flavor characteristics. $^{\text {a }}$

\begin{tabular}{|c|c|c|}
\hline $\begin{array}{c}\text { 2,5- } \\
\text { Dimethylpyrazine }\end{array}$ & Flavors \\
\hline $\begin{array}{c}\text { 2,6- } \\
\text { Dimethylpyrazine }\end{array}$ & $\begin{array}{c}\text { Chocolate, roasted nuts, roasted barley } \\
\text { aroma, chocolate taste, butter odor, } \\
\text { fried potatoes. }\end{array}$ \\
\hline $\begin{array}{c}\text { 2,3- } \\
\text { Dimethylpyrazine } \\
\text { methylpyrazine }\end{array}$ & $\begin{array}{c}\text { Roasted, coffee, nutty, peanuts, } \\
\text { chocolate flavor, potato aroma. }\end{array}$ \\
\hline $\begin{array}{c}\text { 2-Ethyl-5- } \\
\text { methylpyrazine }\end{array}$
\end{tabular}

${ }^{\mathrm{a}}$ References:(Leffingwell, 2004; Mihara \& Masuda, 1988; Zhang et al., 2010)

In relation to the ingredients used in the recipes of meat products and according to previous studies, the presence of natural phenolic compounds may inhibit or promote the formation of pyrazines affecting the quality of the final product (Misnawi et al., 2004; Porter et al., 2006; Wilker et al., 2015). Contradictory effects were exerted by pure phenolics, whereas gallic acid almost completely inhibited pyrazine formation, ellagic acid showed strong promoting activity (Porter et al., 2006). Misnawi et al. (2004) detected that the increase of polyphenol levels limited the formation of pyrazines in roasting process. The inhibition was different for each pyrazine, being 2,3dimethylpyrazine the most strongly affected. Authors also observed that the presence of polyphenols reduced the level of free amino acid and reducing sugar, limiting their participation in the Maillard reaction. However, Wilker et al. (2015) observed that pure polyphenols, specially gallic acid, are able to promote the Maillard reaction. This fact 
was explained by their ferric reducing capacity, inducing Fenton reaction and glucose degradation cyclically. The effect was less pronounced at high levels of polyphenols, which was ascribed to the metal chelation activities of polymerized polyphenols.

Natural products rich in antioxidants also showed different effects, so in the case of grape skin and seed extracts a complete inhibition of pyrazine formation was described whereas, in contrast, rosemary seasoning enhanced the formation of pyrazines (Porter et al., 2006).

A considerable amount of literature has been published on the application of the electronic nose to assay the quality of meat products (Wilson \& Baietto, 2009) and, according to the review done by Elmore (2008), metal oxides sensors have been successfully applied to study the aroma of different cooked meat products and satisfactory correlations with sensory results have been obtained. From these facts, electronic nose could be a suitable tool to study the odor modification of roasted patties induced by the inhibition or promotion of pyrazine formation.

Recently, new natural seasonings derived from wine pomace, have been successfully applied to different food matrices, including beef patties (Garcia-Lomillo et al., 2016). The seasonings were characterized in terms of main chemical composition, mineral, phenolic composition, radical scavenging and ferric reducing activities (Del Pino-García et al., 2015; García-Lomillo et al., 2014). Then, considering the future applications of these seasonings in meat product recipes, the aim of this study was to evaluate the effect of one of these seasonings on the formation of pyrazines in barbecued beef patties. The seasoning used in the present study was chosen due to its intense antioxidant and preservatives properties. 


\section{MATERIALS AND METHODS}

\subsection{Material}

Beef meat and salt was purchased in a special grocery wholesale store placed in Burgos (Gros Mercat, Burgos, Spain), and a commercially available mixture of phosphates and starch was provided by Doscadesa (Murcia, Spain). The seasoning derived from red wine pomace (RWPS) was made in the pilot plant of the Food Technology Area (University of Burgos) according to the patented process (González San José et al., 2015).

\subsection{Preparation and cooking of samples}

Beef patties were prepared according to the process described by GarciaLomillo et al. (2016). Briefly, control patties were prepared from beef meat that was minced and mixed with $1.2 \%$ of starch, $0.3 \%$ of phosphates and $1.5 \%$ salt previously dissolved in $5 \%$ of water. After mixing, balls of $100 \mathrm{~g}$ of mixed meat were gently handmade and flatten into one cm-thick patties. RWPS patties were made similarly but $2 \%$ of the studied seasoning was added during mixing process. The $\mathrm{pH}$ of raw patties was assessed using a Crison 2001 pH meter (Crison, Barcelona, Spain).

Patties were cooked in a charcoal barbecue, where racks were positioned at 8 $\mathrm{cm}$ of distance from the heat source, where temperatures reached $200 \pm 3{ }^{\circ} \mathrm{C}$. Samples were turned once during grilling at half of the total cooking time ( 7 minutes). After cooking, patties were immediately cooled, and four patties were preserved to pyrazine analysis (Figure 8.1.). The assay was carried by duplicate, so two different mixings were made for each type of patty. 


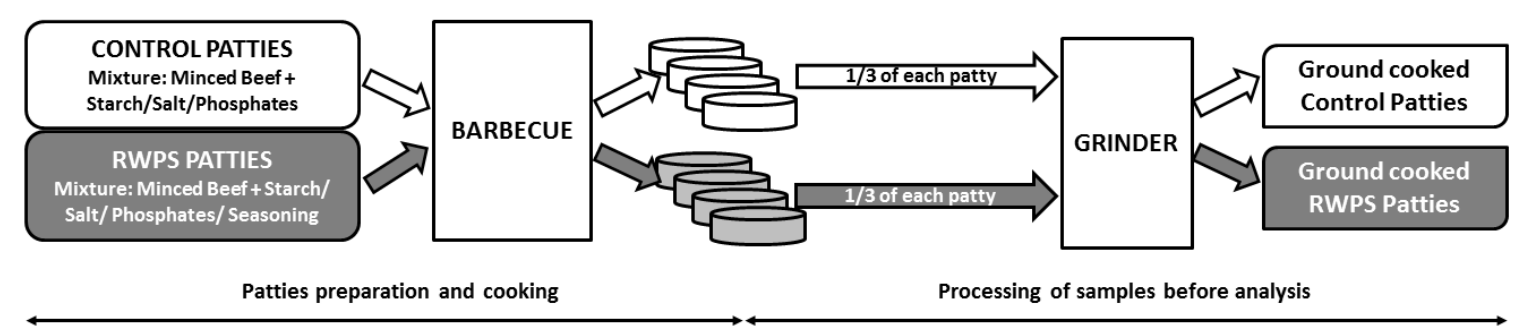

Figure 8.1. Scheme of sampling preparation.

\subsection{Determination of pyrazine contents}

Levels of pyrazines were measured directly on ground cooked patties. A third part of four different cooked patties were ground together to obtain a homogeneous mixture of them (Figure 8.1.). Then, two grams of each mixture (control and RWPS patties) were transferred to a $10 \mathrm{~mL}$ headspace glass vials (Thermo Scientific ${ }^{\mathrm{TM}}$ Chromacol'TM, Barcelona, Spain). Immediately, $5 \mu \mathrm{L}$ of a cyclopentanone: dichloromethane (1:9) solution were added and vials were immediately sealed using a metallic cap with chlorobutyl/PTFE seal (Thermo Scientific ${ }^{\mathrm{TM}}$ Chromacol $^{\mathrm{TM}}$ ). Cyclopentanone is added as internal standard for gas chromatography-mass spectrometry (GC-MS) analysis. Five vials for each type of patties were prepared. After sealing, vials were analysed as soon as possible, and they were kept at $4^{\circ} \mathrm{C}$ until analysis. The experiment was repeated with the two different beef meat batches.

Pyrazines were analyzed using a solid-phase dynamic extraction (SPDE) equipment (Bender and Hobein, Zurich, Switzerland) and according to the method developed by Corcuera Tecedor (2013). The extractions were conducted with a previously acconditionated PDMS/AC (90\% polydimethylsiloxane and 10\% activated carbon) fiber at $55^{\circ} \mathrm{C}$. After 50 strokes, the fiber was transferred to the injection port of a GC-MS equipment (Agilent Technologies 6890N). Volatile compounds were thermally desorbed from the fiber in the injection port at $250^{\circ} \mathrm{C}$ and using helium as 
carrier gas. The separation was conducted in 007-WAX capillary column (Quadrex Corporation, New Haven, USA) (60 m length, $0.32 \mathrm{~mm}$ inside diameter and $1 \mu \mathrm{m}$ film thickness). Compounds were identified by comparison to the mass spectra of the Wiley 7th and NIST 98 libraries. Standard calibration curves were conducted for quantitative determination. According to the author, calibration curves showed good linearity, repeatability and recoveries $\left(\mathrm{R}^{2}>0.99 ;\right.$ R.S.D $<10 \%$ and, $>95 \%$, respectively) (Corcuera Tecedor, 2013). Moreover, the odor units and the relative odor units were calculated for each pyrazine and each batch according to equations 1 and 2 as described by Lawless \& Heymann (2010):

Odor Units ${ }_{\mathrm{a}}=$ Concentration $_{\mathrm{a}} /$ Threshold $_{\mathrm{a}}$

Relative Odor Units ${ }_{\mathrm{a}}=$ Odor Units $\mathrm{a}_{\mathrm{a}} / \sum$ Odor Units $* 100$

\subsection{Odor profile analysed by electronic nose}

Odor profile was also measured directly on grounded cooked patties. After grounding together a third part of each patties, two grams of the grounded mixture were placed in vials, similarly to the described GC-MS analysis, although in this case cyclopentanone was not added.

To determine the odor profile of each type of patties, vials were incubated during 10 minutes at $55^{\circ} \mathrm{C}$ with an autosampler HS100 CTC-Combi-Pal (CTC Analytics AG, Zwingen, Switzerland). Then, a volume of the headspace was injected in a $\alpha$-FOX 4000 electronic nose (AlfaMOS, Toulouse, Francia) equipped with metal oxide sensors, and the sensor responses were collected during two minutes. The resistance in each sensor was assayed by the software AlphaSoft version 9.1 and the response intensity was calculated as the decrease in the resistance in each sensors $\left(\mathrm{R}_{0}-\right.$ $\mathrm{R})$ in relation to resistance at time zero $\left(\mathrm{R}_{0}\right)$, according to equation 3 : 
Response intensity $=\left(\mathrm{R}_{0}-\mathrm{R}\right) / \mathrm{R}_{0}$

The maximum response intensity was used to evaluate the difference in the odor profile between samples with or without seasoning. Samples were analyzed five times for each type of patty and batch.

\subsection{Statistical analysis}

Fisher's least significant difference $(\mathrm{LSD})$ test $(\mathrm{p}$-value $<0.05)$ was performed using Statgraphics Centurion XVI to identify significant differences between the concentration of each pyrazine of control and RWPS patties, so as between the sensor response obtained after analyzed control and RWPS patties. Statgraphics Centurion XVI was used to carry out the statistical analysis.

\section{RESULTS AND DISCUSSION}

\subsection{Effect of the new seasoning on the formation of pyrazines}

Different pyrazines, mainly the five indicated in Table 8.1., have been previously described in diverse cooked meat products (Madruga et al., 2009; Mottram, 1985). These five commonly described pyrazines were identified and successfully quantified in both control and RWPS patties (Table 8.2.). The global level of dimethyl pyrazines (around 72\%) was higher than ethyl-methyl pyrazines. Two of the three identified dimethyl-pyrazines (2,5-dimethylpyrazine and 2,6-dimethylpyrazine) showed the highest levels, while the third (2,3-dimethylpyrazine) showed the lowest level, in both types of patties. These observations are in agreement with previous studies that indicate the high prevalence of 2,5 and 2,6-dimethylpyrazine (Madruga et al., 2009; Mottram, 1985). 
Table 8.2. Concentration (mean $\pm \mathrm{SD}$ ) of five pyrazines $(\mathrm{ppb})$ in barbecued beef patties without (Control) and with Red Wine Pomace Seasoning (RWPS). ${ }^{\text {a }}$

\begin{tabular}{|c|c|c|c|c|c|c|c|}
\hline \multirow[b]{2}{*}{ Pyrazines } & \multirow[b]{2}{*}{$\begin{array}{c}\text { Thres- } \\
\text { hold } \\
\text { (ppb) }\end{array}$} & \multicolumn{3}{|c|}{ Control } & \multicolumn{3}{|c|}{ RWPS } \\
\hline & & $\begin{array}{l}\text { Mean } \\
(\mathbf{p p b})\end{array}$ & $\begin{array}{l}\text { Odor } \\
\text { Units }\end{array}$ & $\begin{array}{l}\text { Rel. } \\
\text { Odor } \\
\text { Unit } \\
(\%)\end{array}$ & Mean (ppb) & $\begin{array}{l}\text { Odor } \\
\text { Units }\end{array}$ & $\begin{array}{l}\text { Rel. } \\
\text { Odor } \\
\text { Unit } \\
(\%)\end{array}$ \\
\hline $\begin{array}{c}\text { 2,3- } \\
\text { Dimethylpyrazine }\end{array}$ & 800 & $22 \pm 2 a$ & 0.03 & 0.3 & $53 \pm 4 b$ & 0.07 & 0.3 \\
\hline $\begin{array}{c}2,5- \\
\text { Dimethylpyrazine }\end{array}$ & 80 & $201 \pm 9 \mathrm{a}$ & 2.5 & 26 & $394 \pm 63 b$ & 4.9 & 24 \\
\hline $\begin{array}{c}2,6- \\
\text { Dimethylpyrazine }\end{array}$ & 400 & $164 \pm 19 a$ & 0.4 & 4 & $317 \pm 9 b$ & 0.8 & 4 \\
\hline $\begin{array}{c}\text { 2-Ethyl-5- } \\
\text { methylpyrazine }\end{array}$ & 16 & $78 \pm 6 a$ & 4.9 & 51 & $160 \pm 15 b$ & 10.0 & 48 \\
\hline $\begin{array}{l}\text { 2-Ethyl-6- } \\
\text { methylpyrazine }\end{array}$ & 40 & $70 \pm 4 \mathrm{a}$ & 1.8 & 19 & $201 \pm 19 b$ & 5.0 & 24 \\
\hline Sum of pyrazines & & $535 \pm 40 a$ & 9.6 & & $1123 \pm 120 b$ & 20.8 & \\
\hline
\end{tabular}

${ }^{\mathrm{a}}$ Different letters $(\mathrm{a}-\mathrm{b})$ denote significant differences (LSD test and $\left.\mathrm{P}<0.05\right)$ between samples. Values are means \pm standard deviation of four replicate determinations in two different batches, $(\mathrm{n}=10 ; 2$ batches $\mathrm{x} 5$ replicates by sample)

The use of the new seasoning significantly enhanced the formation of the five identified pyrazines (Table 8.2.). The sum of all pyrazines was 2.1 times higher in RWPS patties than in control patties. Dimethyl pyrazines increased around 2 times and ethyl-methyl pyrazines increased around 2.5 times. The highest increase was observed in 2-ethyl-6-methylpyrazine, whose concentration was almost 3 times higher in RWPS patties than in control patties.

Generally, the formation of pyrazines is desired in the food processing since it improves the overall sensory preference with low risk of unpleasant attributes caused by excessive pyrazine formation (El-Ghorab et al., 2010; Jayasena et al., 2013; Mihara \& Masuda, 1988). According to the direct correlation of pyrazines with the "roasted" flavor, which is highly appreciated by consumers (El-Ghorab et al., 2010), it seems possible to assert that the new seasoning produced an interesting enhancement of 
roasted odor notes. This assertion is supported by the detected levels of pyrazines as well as by the obtained values of odor units for each pyrazines (Table 8.2.).

It is accepted that volatile compounds are perceived when their concentrations are superior to their threshold or in other words, when the odor units are equal o superior to 1 . Then, at least three of the five pyrazines analyzed showed enough concentration to be perceived. Dimethyl pyrazines have higher threshold than ethylmethyl pyrazines and for that reason, although they were predominant in concentration (72\%), they had minor contribution to the global odor units (around 30\%). According to the low threshold value of 2-ethyl-5-methylpyrazine, it showed the major potential to contribute to roasted odor note, which was associated to the highest odor unit in both samples (4.9 and 10.0 in control and RWPS patties, respectively). Furthermore, 2ethyl-5-methylpyrazine presented the highest relative odor unit, approximately $50 \%$, in both type of patties (Table 8.2.), suggesting its major role in the "roasted" odor notes.

It is interesting to point out that the odor intensity was increased by the incorporation of the seasoning. Patties elaborated with the seasoning showed higher values of odor units than control patties (around 2.2 times higher), being the odor units of the ethyl-methyl pyrazines those that presented a more intense increase. So, the relative odor of these two pyrazines was slightly higher in RPWS patties (72\%) than in control (70\%).

Considering these facts, and as a preliminary approximation of the possible sensory response, the "odor profile" of patties was analyzed by an e-nose equipment formed by 18 metal oxides sensors. Data from seven (LY2/LG, LY2/G, LY2/AA, LY2/Gh, LY2/gCT1, LY2/gCT and P30/2) of 18 sensors were not included in the analysis, due to their low responses (response intensity lower than 0.05). (Figure 8.2) 


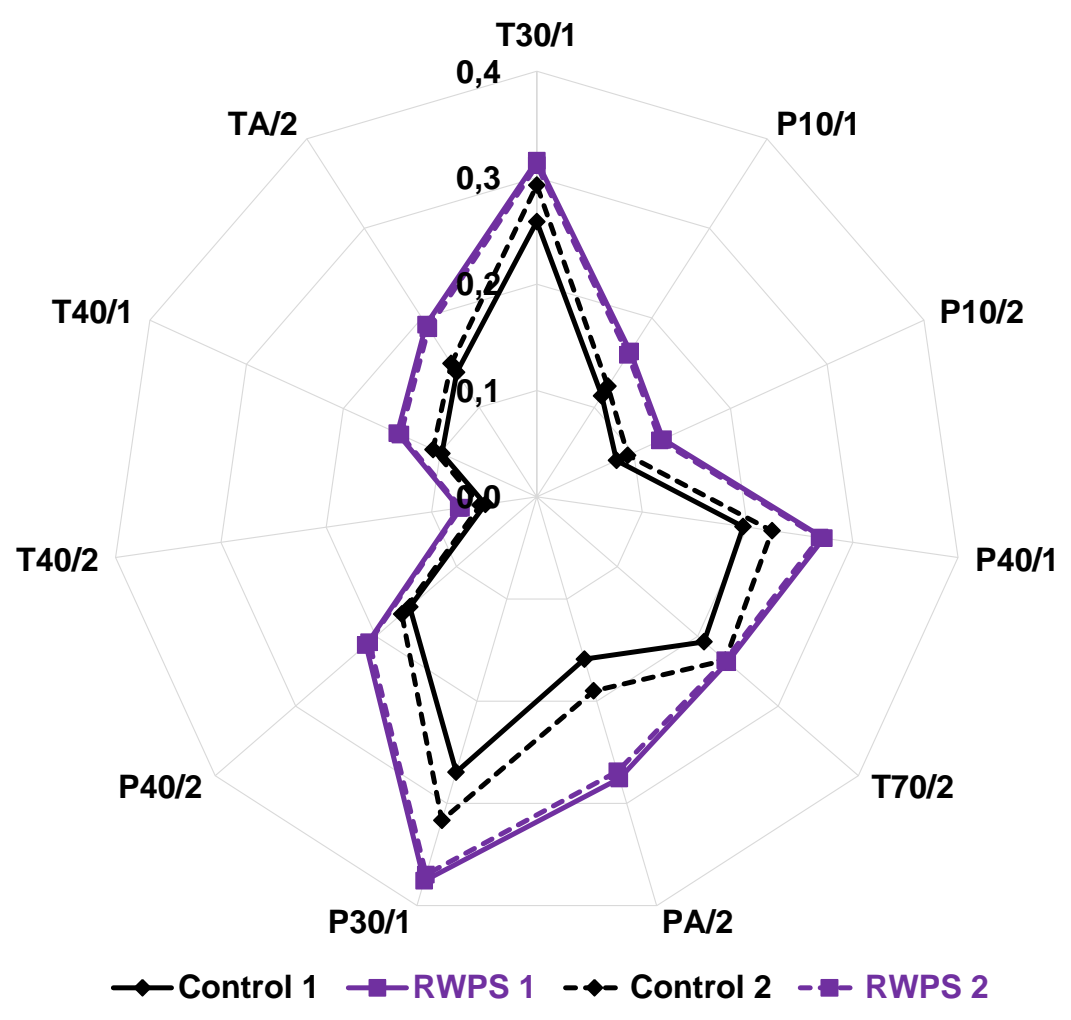

Figure 8.2. Odor profile of the two different batches of beef patties barbecued without (control) or with red wine pomace seasoning (RPWS), evaluated by the response intensity $\left(\left(\mathrm{R}_{0}-\mathrm{R}\right) / \mathrm{R}_{0}\right)$ of 11 sensors from an $\alpha$-FOX electronic nose.

Results obtained with e-nose equipment corroborated the previous results obtained in the pyrazine analysis, which indicate the stronger roasted flavor of the patties made with the seasoning. In evaluated 11 sensors, patties with RWPS showed significantly higher response intensities than control (Figure 8.2.). These observations agree with the results obtained by Gardner et al. (1992), who also observed an increase in the sensor response with increasing roasting times in coffees. The highest differences were observed in sensors $\mathrm{P} 30 / 1$ and PA/2. Interestingly, this type of sensors has been previously linked to the roasted odor of different food products (Gardner et al., 1992; He et al., 2015). Furthermore, P30/1 was also successfully applied to discriminate different coffees according to their roasting degree (Michishita et al., 2010). According to the higher sensor responses, the global area of the "odor profile", which can be 
considered as an index of the global odor intensity, was clearly higher (around 1.6 times) in the case of RWPS patties (Figure 8.2.).

\subsection{Possible mechanisms explaining the pyrazine-promoting effect}

The formation of pyrazines is governed by Maillard-type reactions that take place in processes at high temperatures. The main route of pyrazine formation is the condensation of Strecker aldehydes, which usually proceed from Strecker degradation. Chemically, the Strecker degradation is a decarboxylation of $\alpha$-dicarbonyls, which usually proceed from sugars (Müller \& Rappert, 2010), although new sources of $\alpha$ dicarbonyls as quinones derived from polyphenols have recently been described (Rizzi, 2006). Natural antioxidants, such as polyphenols, have been shown to promote Maillard-type reactions (Rizzi, 2006; Wilker et al., 2015), although previous studies also reported lower levels of pyrazines and roasted flavor in coffees with higher polyphenolic contents (Misnawi et al., 2004).

According to the seasoning composition and properties (Del Pino-García et al., 2015; García-Lomillo et al., 2014) several factors, such as minerals, pH modifications and polyphenol contents could contribute to the pyrazine-promoting effect exerted by the seasoning. Among them, the polyphenol seems to be the main factor. Relatively slight modifications between the composition of control and RWPS patties were observed (data not shown). Ash content was similar in both type of patties, and no significant differences between metal levels were detected. The incorporation of RWPS reduced notably the values of $\mathrm{pH}$ (from 5.89 to 5.45), however stronger $\mathrm{pH}$ reductions (from 7 to 5) did not affect Maillard reaction (Wilker et al., 2015). The level of total polyphenols was the parameter most intensively modified by the seasoning incorporation. RWPS patties showed Folin Index values around twice higher than 
control samples (data not showed). This difference was directly correlated to the high polyphenol content of RPWS (24.4 mg /g expressed as gallic acid equivalents) (GarcíaLomillo et al., 2014). Consequently, polyphenols are the most probable cause of the observed increase in the pyrazine levels of RWPS patties.

The capacity of polyphenols to promote the formation of $\alpha$-dicarbonyls derived from carbohydrates have been associated to their high capacity to reduce metals (Wilker et al., 2015). Interestingly, carbohydrates derived in $\alpha$-dicarbonyls only in model solution containing metals. This fact pointed out the role of metals in the propyrazine activity of polyphenols (Wilker et al., 2015). Extending this observation to patties, it is assumable that reduced metals, mainly iron, may cyclically participate in the Fenton reaction, generating hydroxyl radicals (Figure 8.3.). These radicals are able to accelerate hexose degradation, and continuously form $\alpha$-dicarbonyls, which participate in the Strecker degradation of amino acids and subsequently in the formation of pyrazines. This assumption is supported by the strong ferric reducing capacity showed by the seasoning (FRAP assay values of $275 \mu \mathrm{mol} F e(\mathrm{II}) / \mathrm{g}$ product) (Del Pino-García et al., 2015).

In addition to the promoting effect on carbohydrate degradation, polyphenols, in their quinone state, can also participate in the Strecker degradation of amino acids. As a result, new Strecker aldehydes are formed, which may undergo further condensation (Figure 8.3.), and contribute to the pyrazine formation (Rizzi, 2006).

Physical aspects of the matrix may also explain the high levels of pyrazines detected in samples with RWPS, since protein play a key role in the release of volatiles from matrix to headspace (Pérez-Juan et al., 2008). RWPS was reported to interact with beef proteins (Garcia-Lomillo et al., 2016), which may promote the release of volatiles 
from matrix to headspace. In this sense, RWPS could imitate the effect produced by salt that also enhances the release of volatiles from matrix (Pérez-Juan et al., 2008).

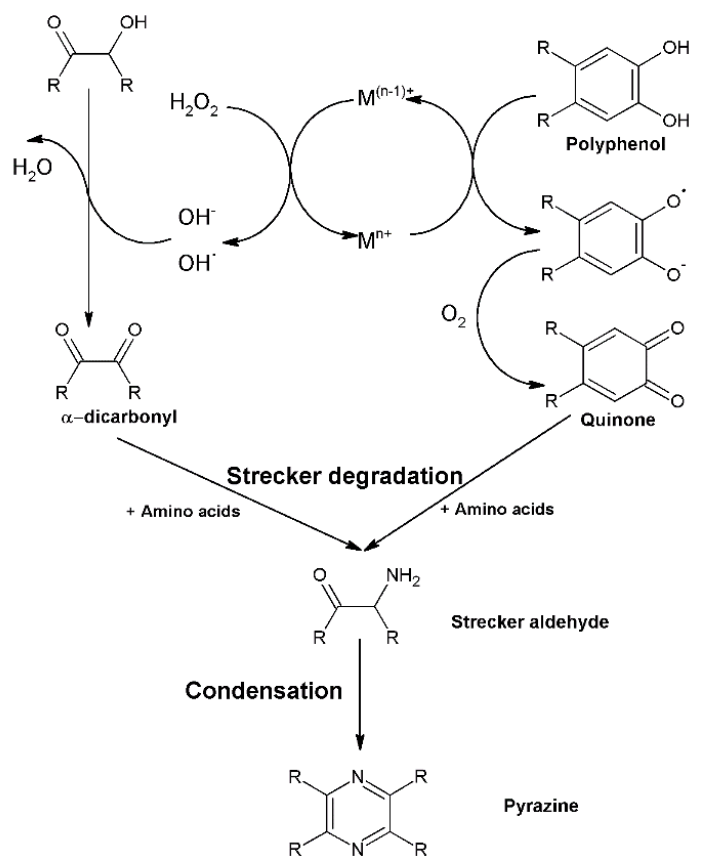

Figure 8.3. Reaction pathways proposed to explain the higher formation of pyrazines exerted by polyphenols of the studied seasoning. Adapted from: (Müller \& Rappert, 2010; Rizzi, 2006; Wilker et al., 2015).

\section{CONCLUSIONS}

The new seasoning enhanced the formation of pyrazines in the cooking process of beef patties. Although the mechanism and the specific agents responsible of the observed results remain unknown, it is possible to assert that RWPS is able to promote the formation of pyrazines, contributing to an adequate odor profile of patties, and increase the intensity of the odor evaluated by electronic nose. Interestingly, the new seasoning may enable the use of less intense cooking conditions without affecting the "roast" flavor of the final product, using only natural additives. 


\section{REFERENCES}

Corcuera Tecedor, E. (2013). Estudio de la aptitud de un aroma natural obtenido a partir de subproductos de buey de mar (Cancer Pagurus) para su aplicación a distintas matrices alimentarias. Universidad de Burgos.

Del Pino-García, R., García-Lomillo, J., Rivero-Pérez, M. D., González-SanJosé, M. L., \& Muñiz, P. (2015). Adaptation and Validation of QUick, Easy, New, CHEap, and Reproducible (QUENCHER) Antioxidant Capacity Assays in Model Products Obtained from Residual Wine Pomace. Journal of Agricultural and Food Chemistry, 63(31), 6922-6931.

EFSA. (2008). Flavouring Group Evaluation 17, Revision 1 (FGE.17Rev1): Pyrazine derivatives from chemical group 24. Opinion of the Scientific Panel on Food Additives, Flavourings, Processing Aids and Materials in contact with Food (AFC). The EFSA Journal, 812, 1-59.

El-Ghorab, A. H., El-Massry, K. F., Shedied, S. A., Shaheen, M. S., Osman, F., \& ElHadaad, A. F. (2010). Effect of water content chemical composition and antioxidant activity from volatile generated from beef fat in maillard reaction. Egyptian Journal of Chemistry, 53(3), 367-383.

Elmore, J. S. (2008). Aroma. Handbook of Muscle Foods Analysis, (pp. 241-262): CRC Press.

Farah, D. M. H., Zaibunnisa, A. H., \& Misnawi. (2012). Optimization of cocoa beans roasting process using response surface methodology based on concentration of pyrazine and acrylamide. International Food Research Journal, 19(4), 13551359.

Garcia-Lomillo, J., González-SanJosé, M., Skibsted, L., \& Jongberg, S. (2016). Effect of Skin Wine Pomace and Sulfite on Protein Oxidation in Beef Patties During High Oxygen Atmosphere Storage. Food and Bioprocess Technology, 9(3), 532-542.

García-Lomillo, J., González-SanJosé, M. L., Del Pino-García, R., Rivero-Pérez, M. D., \& Muñiz-Rodríguez, P. (2014). Antioxidant and antimicrobial properties of wine byproducts and their potential uses in the food industry. Journal of Agricultural and Food Chemistry, 62(52), 12595-12602.

Gardner, J. W., Shurmer, H. V., \& Tan, T. T. (1992). Application of an electronic nose to the discrimination of coffees. Sensors and Actuators: B. Chemical, 6(1-3), 71-75.

González San José, M. L., García Lomillo, J., Del Pino García, R., Dolores Rivero, M., \& Muñiz Rodríguez, P. (2015). Sazonador de origen vegetal con propiedades conservantes, sustitutivo de la sal, y procedimiento de obtención del mismo. ES2524870 B2. Spain.

He, Y., Hu, R., Zhang, H., Wen, N., Cai, T., Peng, J., \& Xu, Y. (2015). Characteristic aroma detection of coffee at different roasting degree based on electronic nose. Nongye Gongcheng Xuebao/Transactions of the Chinese Society of Agricultural Engineering, 31(18), 247-255. 
Jayasena, D. D., Ahn, D. U., Nam, K. C., \& Jo, C. (2013). Factors affecting cooked chicken meat flavour: A review. World's Poultry Science Journal, 69(3), 515526.

Jiao, S., Zhu, D., Deng, Y., \& Zhao, Y. (2015). Effects of Hot Air-assisted Radio Frequency Heating on Quality and Shelf-life of Roasted Peanuts. Food and Bioprocess Technology, 1-12.

Jung, M. Y., Bock, J. Y., Baik, S. O., Lee, J. H., \& Lee, T. K. (1999). Effects of roasting on pyrazine contents and oxidative stability of red pepper seed oil prior to its extraction. Journal of Agricultural and Food Chemistry, 47(4), 17001704.

Lawless, H. T., \& Heymann, H. (2010). Time-Intensity Methods. Sensory Evaluation of Food, (pp. 179-201): Springer New York.

Leffingwell, J. C. (2004). Flavor-base. Leffingwell and Associates.

Madruga, M. S., Stephen Elmore, J., Dodson, A. T., \& Mottram, D. S. (2009). Volatile flavour profile of goat meat extracted by three widely used techniques. Food Chemistry, 115(3), 1081-1087.

Michishita, T., Akiyama, M., Hirano, Y., Ikeda, M., Sagara, Y., \& Araki, T. (2010). Gas Chromatography/Olfactometry and Electronic Nose Analyses of Retronasal Aroma of Espresso and Correlation with Sensory Evaluation by an Artificial Neural Network. Journal of Food Science, 75(9), S477-S489.

Mihara, S., \& Masuda, H. (1988). Structure-odor relationships for disubstituted pyrazines. Journal of Agricultural and Food Chemistry, 36(6), 1242-1247.

Misnawi, Jinap, S., Jamilah, B., \& Nazamid, S. (2004). Effect of polyphenol concentration on pyrazine formation during cocoa liquor roasting. Food Chemistry, 85(1), 73-80.

Mottram, D. S. (1985). The effect of cooking conditions on the formation of volatile heterocyclic compounds in pork. Journal of the Science of Food and Agriculture, 36(5), 377-382.

Müller, R., \& Rappert, S. (2010). Pyrazines: Occurrence, formation and biodegradation. Applied Microbiology and Biotechnology, 85(5), 1315-1320.

Pasqualone, A., Paradiso, V. M., Summo, C., Caponio, F., \& Gomes, T. (2014). Influence of Drying Conditions on Volatile Compounds of Pasta. Food and Bioprocess Technology, 7(3), 719-731.

Pérez-Juan, M., Flores, M., \& Toldrá, F. (2008). Effect of pork meat proteins on the binding of volatile compounds. Food Chemistry, 108(4), 1226-1233.

Porter, W., Conca, K., Yeomans, W., Diotte, S., Lynch, A., \& Tate, J. (2006). Modification of maillard browning in a microwaved glucose/glycine model system by water-soluble natural antioxidants and foods containing them. Journal of the American Oil Chemists' Society, 83(8), 697-705.

Rizzi, G. P. (2006). Formation of Strecker Aldehydes from Polyphenol-Derived Quinones and $\alpha$-Amino Acids in a Nonenzymic Model System. Journal of Agricultural and Food Chemistry, 54(5), 1893-1897. 
Wilker, D., Heinrich, A. B., \& Kroh, L. W. (2015). Model Studies on the Antioxidative Effect of Polyphenols in Thermally Treated d-Glucose/l-Alanine Solutions with Added Metal Ions. Journal of Agricultural and Food Chemistry, 63(51), 1097310979.

Wilson, A. D., \& Baietto, M. (2009). Applications and advances in electronic-nose technologies. Sensors, 9(7), 5099-5148.

Zhang, Y., Li, X., Lo, C.-K., \& Guo, S.-T. (2010). Characterization of the Volatile Substances and Aroma Components from Traditional Soypaste. Molecules, $15(5), 3421$. 



\title{
CONCluSiones FinAleS
}

\author{
Final Conclusions
}





\section{CONCLUSIONES FINALES}

Los resultados obtenidos se pueden resumir en:

- Se ha desarrollado un proceso que permite aprovechar de una forma económica y sencilla, uno de los residuos más importantes de la industria vitivinícola, los orujos de vinificación, transformándolos en sazonadores de uso alimentario.

- Los sazonadores, y en especial el derivado de orujos libres de pepitas, han mostrado ser buenos agentes antioxidantes y antimicrobianos, además de ser fuente de componentes de interés para la elaboración de alimentos saludables como la fibra, los compuestos fenólicos y el potasio.

- Los sazonadores han demostrado capacidad para paliar los efectos negativos de la reducción de sal, así como su contribución a evitar la formación de compuestos negativos durante el cocinado de productos cárnicos, a la vez que favorecen la formación de otros positivos para las características aromáticas de los mismos.

\section{Industrias vitivinícolas}

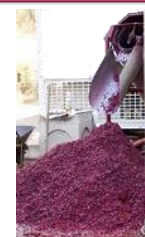

Ahorro de costes

Diversificación de sus productos
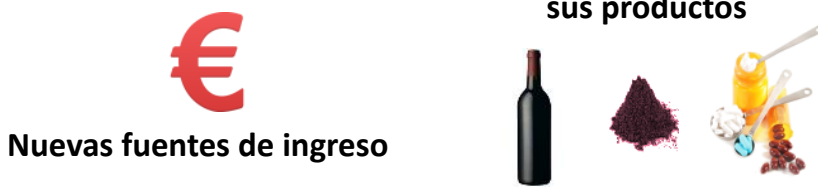

Industrias alimentarias

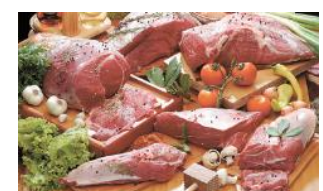

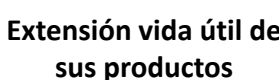

Reducción del uso de aditivos y conservantes

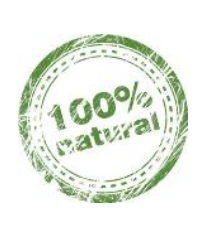

Diseño de alimentos más saludables

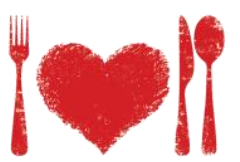

\section{Medioambiente}

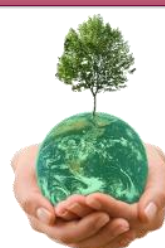

Explotación más eficiente de los recursos

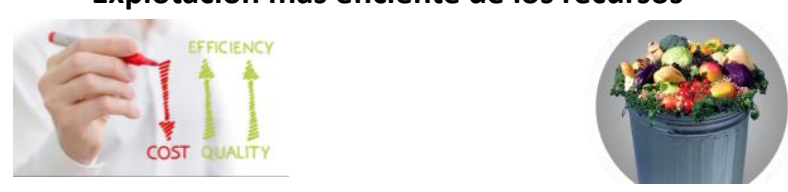

Reducción en alimentos desperdiciados 
Por todo ello se puede concluir que se han cumplido los objetivos que se planificaron al inicio de la tesis. Destacándose como conclusiones finales globales que:

- Los sazonadores desarrollados son un modo satisfactorio de aprovechamiento integral de los residuos de vinificación, siendo una buena alternativa para reducir costes de producción, además de ser una opción para la diversificación de productos derivados de la industria vitivinícola.

- La industria alimentaria dispone de un nuevo ingrediente natural capaz de inhibir diversas reacciones de reducción de la calidad microbiológica y química, que permite reducir el uso de conservantes como la sal y los sulfitos, sin poner en riesgo la estabilidad del producto final. Además, los sazonadores pueden emplearse como ingrediente "funcional" para el enriquecimiento en fibra, minerales (principalmente potasio) y compuestos fenólicos, así como para la reducción de sodio al poder sustituir total o parcialmente la sal.

- En definitiva, se ha desarrollado una propuesta favorable a la producción sostenible de alimentos. Es medioambientalmente eficaz, reduce la cantidad de residuos de las bodegas sin necesidad de utilizar solventes orgánicos ni consumos elevados de energía; además permite reducir el deterioro de alimentos y las pérdidas asociadas; y permite la revalorización de productos agrarios con la consiguiente repercusión económica y social de las regiones vitivinícolas. 


\section{FINAL CONCLUSIONS}

The results obtained in this $\mathrm{PhD}$ thesis can be summarized in the following points:

- It has been developed a new process that enables the integral utilization of the wine pomace in an economical and simple way. The process enables the transformation of wine pomace in new seasonings with interesting applications to the food industry.

- The seasonings, and especially, the seasoning derived from seedless wine pomace, have reported excellent antioxidant and antimicrobial properties. Furthermore, they were good source of interesting components for producing healthy foods such as fiber, phenolic compounds and potassium.

- The seasonings were able to mitigate the negative effects of salt reduction and the formation of negatives compounds during meat cooking, and to enhance the formation of other compounds with positive odorant notes.
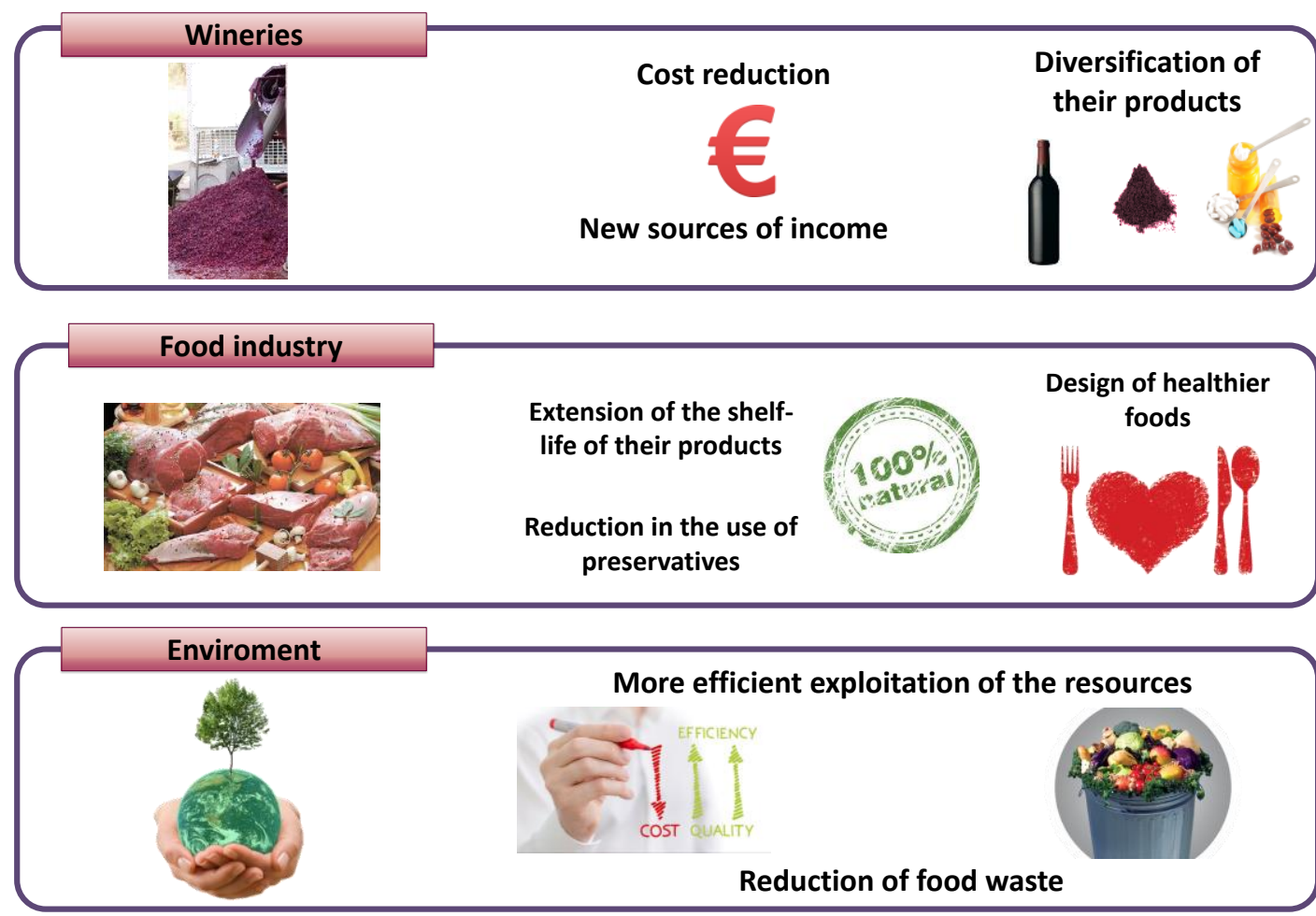
Due to the aforementioned results, it can be concluded that the aims of this $\mathrm{PhD}$ thesis have been successfully completed, and the global conclusions are:

- The developed seasonings are a satisfactory approach to an integral reutilization of wine pomace. They are an excellent alternative to reduce production costs and to diversify the products derived from winery activities.

- The food industry is provided with new natural ingredients that are able to inhibit different microbiological and chemical reactions that reduce the quality of foodstuff, enabling the reduction in the use of food preservatives such as salt and sulfites without compromising the stability of the final product. Furthermore, the seasonings can be used as functional ingredients to increase the content in fiber, minerals (especially potassium) and phenolic compounds and to reduce the sodium content due to partial or complete salt reduction.

- In summary, it has been developed a positive proposal to improve the sustainability of the food production. It is environmentally efficient; reduces residues derived from wineries without using organic solvent or large amount of energy. Furthermore, it reduces food spoilage and the losses associated, enabling the revalorization of agricultural products with the subsequent economic and social impact to the wine-producing regions. 


\section{List of Publications}





\section{LIST OF PUBLICATIONS}

\section{Patent:}

González San José, M.L., García Lomillo, J., Del Pino García, R., Dolores Rivero, M., \& Muñiz Rodríguez, P. (2015). Sazonador de origen vegetal con propiedades conservantes, sustitutivo de la sal, y procedimiento de obtención del mismo. ES2524870 B2. Submitted in June 2013.

\section{Accepted manuscripts:}

García-Lomillo, J., González-SanJosé, M. L., Del Pino-García, R., Rivero-Pérez, M. D., \& Muñiz-Rodríguez, P. (2014). Antioxidant and antimicrobial properties of wine byproducts and their potential uses in the food industry. Journal of Agricultural and Food Chemistry, 62(52), 12595-12602.

Garcia-Lomillo, J., González-SanJosé, M.L., Skibsted, L., \& Jongberg, S. (2016).

Effect of Skin Wine Pomace and Sulfite on Protein Oxidation in Beef Patties During High Oxygen Atmosphere Storage. Food and Bioprocess Technology, 9(3), 532-542.

García-Lomillo, J., González-SanJosé, M. L., Del Pino-García, R., Ortega-Heras, M. D., \& Muñiz-Rodríguez, P. Effect of a new natural seasoning on the formation of pyrazines in barbecued beef patties. Journal of Chemistry. In press

\section{Submitted manuscripts:}

García-Lomillo, J., González-SanJosé, M. L., Del Pino-García, R., Rivero-Pérez, M. D., \& Muñiz-Rodríguez, P. Alternative natural seasoning to improve the microbial stability of low-salt beef patties. Sent in October 2015 to Food Chemistry. Under Final Decision

García-Lomillo, J., González-SanJosé, M. L., Del Pino-García, R., Rivero-Pérez, M. D., \& Muñiz-Rodríguez, P. A new seasoning with potential effect against foodborne pathogens. Sent in April 2016 to Journal of Food Science and Technology.

García-Lomillo, J., González-SanJosé, M. L., Del Pino-García, R., Ortega-Heras, M. D., \& Muñiz-Rodríguez, P. Antioxidant effect of seasonings derived from wine pomace in refrigerated and frozen beef patties. Sent in May 2016 to Food Bioprocess and Technology

García-Lomillo, J., Viegas, O., González-SanJosé, M. L., M. P. L. V. O. Ferreira, I. Effect of red wine pomace seasoning on the formation of meat cooking carcinogens in beef patties before and after storage. Sent in May 2016 to LWTFood Science and Technology 


\section{Awards:}

Patent Innovation Contest, organized by the European Patent Office "Properties and manufacturing process for a salt substitute derived from grape pomace, a byproduct of the wine industry". 2014

Best Poster Award in $1^{\text {st }}$ PLEASURE Conference "Salt-Sugar-Lipids Reduction": "Use of a new seasoning derived from grape pomace to extend the shelf-life of low-salt beef patties". 2014

Best Poster Award in World Bulk Wine 2014: "Seasoning products from wine pomace with interesting preservative and healthful properties". 2014 

